\title{
ILLÓOLAJOK HATÁSA TOXINTERMELŐ FONALASGOMBA FAJOKRA
}

\section{DOKTORI ÉRTEKEZÉS}

\section{VERES CSILLA}

\author{
TÉMAVEZETŐK: \\ DR. KRISCH JUDIT ÉVA \\ EGYETEMI DOCENS \\ PROF. DR. VÁGVÖLGYI CSABA \\ TANSZÉKVEZETŐ EGYETEMI TANÁR
}

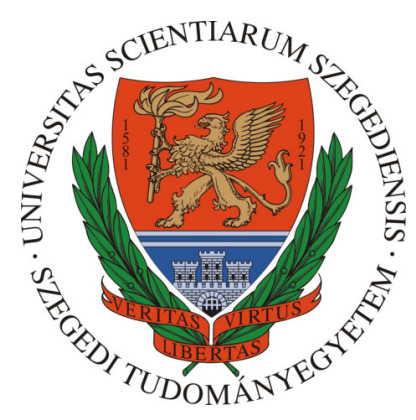

BIOLÓGIA DOKTORI ISKOLA

SZEGEDI TUDOMÁNYEGYETEM

TERMÉSZETTUDOMÁNYI ÉS INFORMATIKAI KAR

MIKROBIOLÓGIAI TANSZÉK

SZEGED 


\section{Tartalomjegyzék}

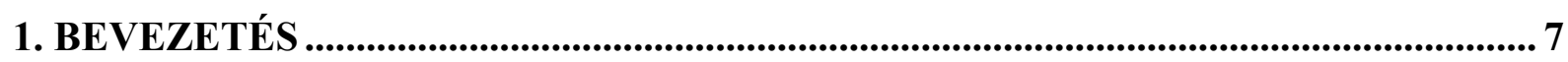

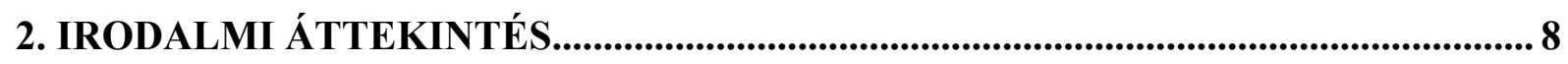

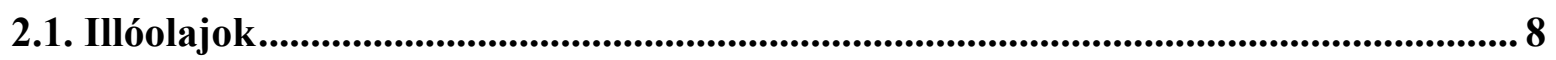

2.1.1. Az illóolajok története és jellemzése ….............................................................. 8

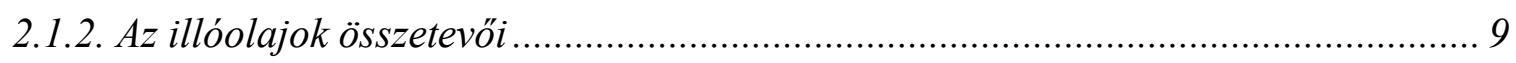

2.1.3. Az illóolajok alkalmazási területe, hatása ......................................................... 11

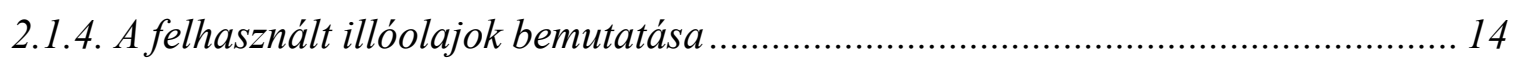

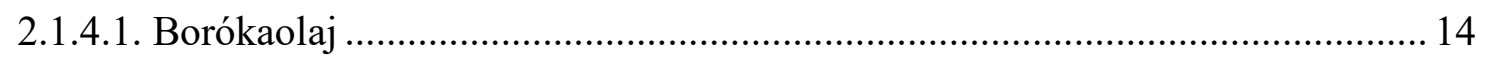

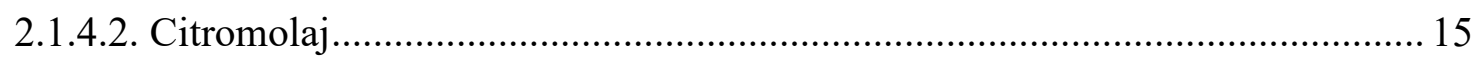

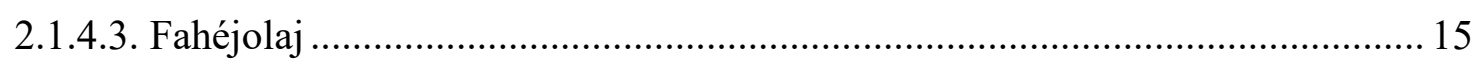

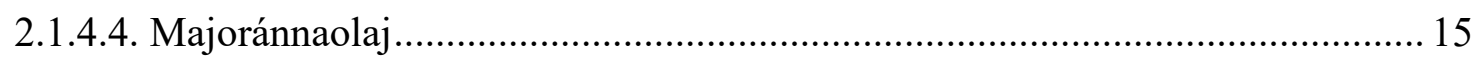

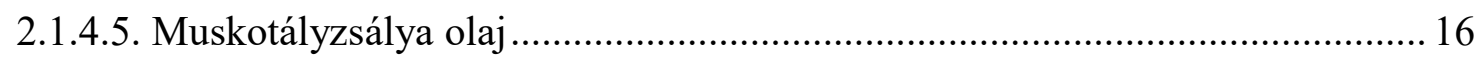

2.2. Tömlösgombák ........................................................................................................................ 16

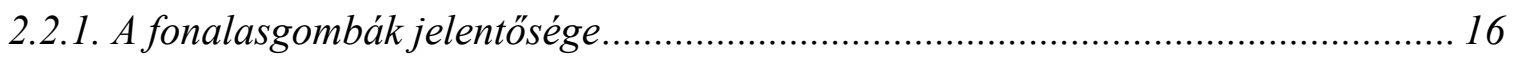

2.2.2. A kisérletekbe bevont fonalasgombák bemutatása ........................................... 17

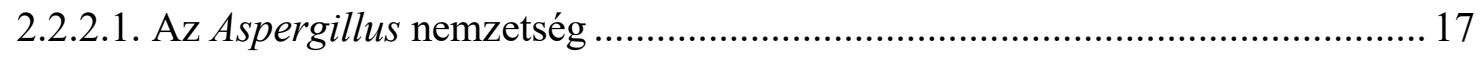

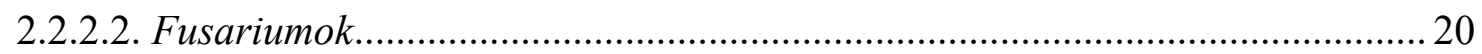

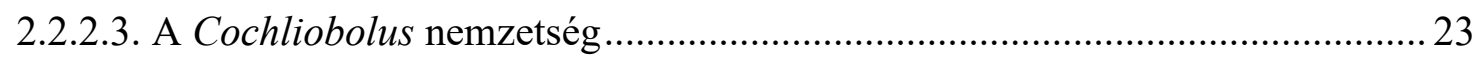

2.3. Tömlösgombák mikotoxinjai .................................................................................. 24

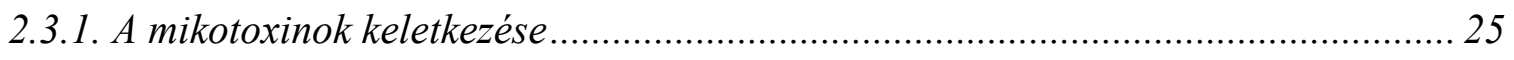

2.3.2. A mikotoxinok és az élelmiszerbiztonság. Az élelmiszerek toxinszennyezetsége

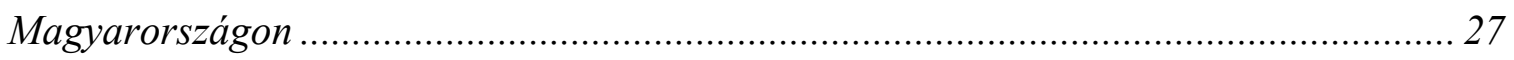

2.3.3. Illóolajok hatása a fonalas gombák mikotoxin termelésére ................................ 28

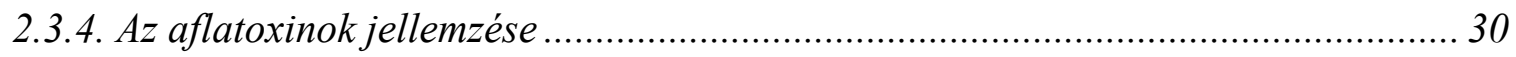

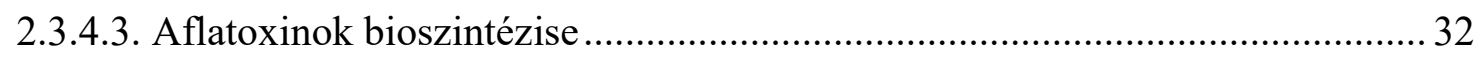


2.3.4.2. Az aflatoxin előfordulása, a toxinképződés feltételei

2.3.4.3. Az aflatoxinok biológiai hatása, az aflatoxikózis....................................... 34

2.3.4.4. Az aflatoxinra megállapított határértékek .............................................. 35

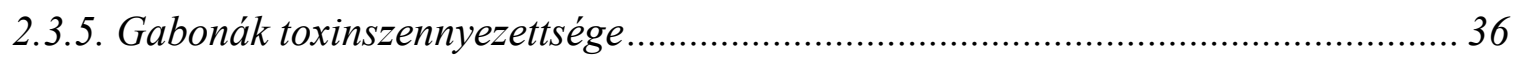

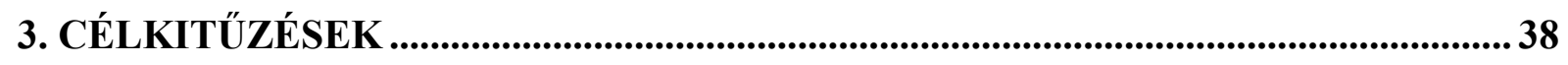

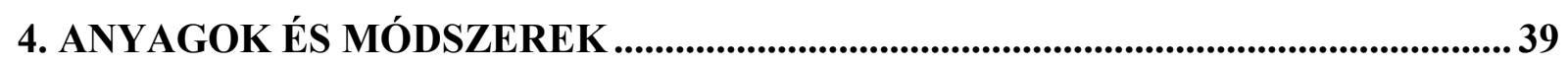

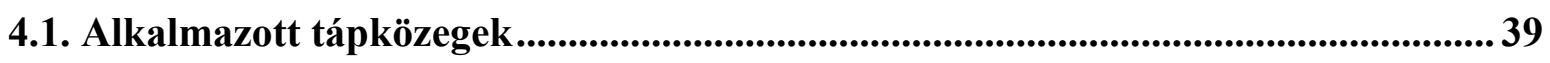

4.2. Alkalmazott mikroorganizmusok ..................................................................... 39

4.3. Alkalmazott illóolajok ................................................................................. 40

4.4. Alkalmazott természetes szubsztrát (búza) .................................................... 40

4.5. Antifungális hatás vizsgálata ..................................................................... 40

4.5.1. Illóolajok hatása a fonalasgombák növekedési paramétereire ............................ 40

4.5.2. A minimális gátló koncentráció (MIC) meghatározása ....................................... 41

4.6. Illóolajok hatása az Aspergillus-ok aflatoxin termelésére ........................................ 42

4.6.1. Szilárd táptalajon nevelt tenyészetek aflatoxin termelésének detektálása .............. 42

4.6.2. Illóolajok hatása tápoldatos fermentáció során - az aflatoxin termelés

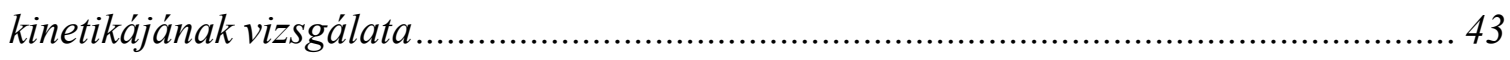

4.6.3. A. parasiticus tenyésztése búza szubsztráton .................................................... 43

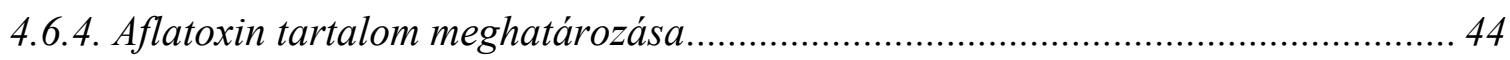

4.6.4.1. Aflatoxin meghatározása szilárd táptalajon tenyésztett $A$. parasiticus esetén . 44

4.6.4.2. Aflatoxin meghatározása folyadékközegben és búza szubsztráton tenyésztett $A$.

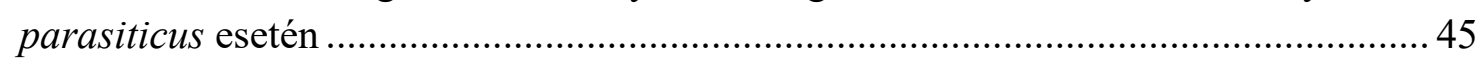

4.7. Az illóolajok hatása a fonalasgombák morfológiai változásaira ........................... 46

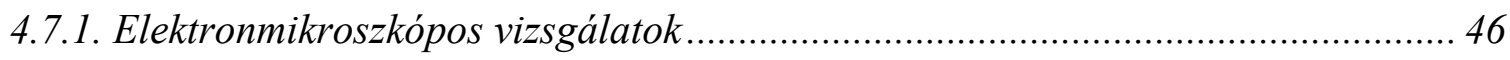

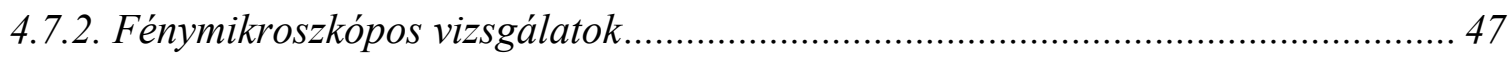

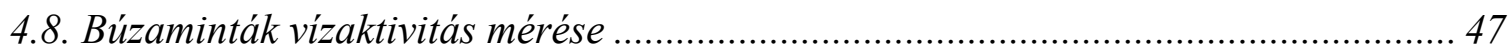

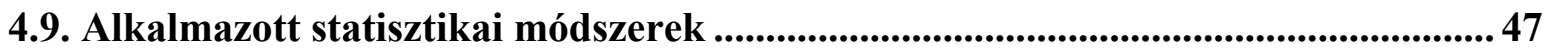




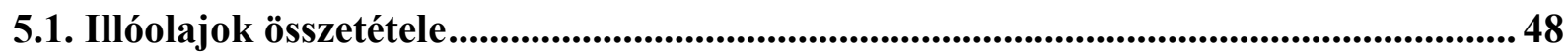

5.2. Illóolajok antifungális hatása ..................................................................................... 48

5.3. A minimális gátló koncentráció (MIC) meghatározása agar hígításos módszer és fordított Petri-csésze módszer alkalmazása esetén....................................................... 48

5.4. Illóolajok hatása a fonalasgombák telepnövekedésére........................................50

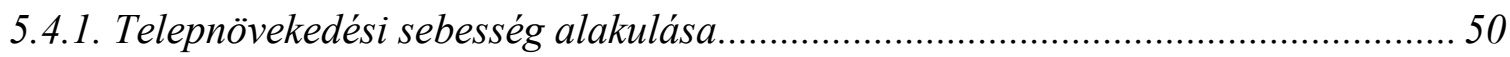

5.4.1.1. Aspergillus-ok telepnövekedési sebességének alakulása illóolaj gőztérben .... 50

5.4.1.2. Fusarium-ok telepnövekedési sebességének alakulása illóolaj gőztérben....... 51

5.4.1.3. C. hawaiiensis telepnövekedési sebességének alakulása illóolaj gőztérben .... 52

5.4.1.4. Fonalasgombák telepnövekedési sebességének alakulása agar-hígításos

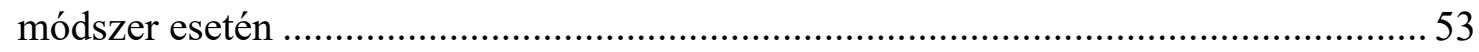

5.4.2. Antifungális indexek alakulása illóolaj göztérben ........................................... 57

5.5. Illóolajok hatása az $A . p a r a s i t i c u s$ és az A.nomius aflatoxin termelésére ................ 58

5.5.1. Szilárd táptalajon tenyésztett A. parasiticus aflatoxin termelése ...........................59

5.5.1.1. Az A. parasiticus konídiumképzésének és morfológiai karakterisztikájának

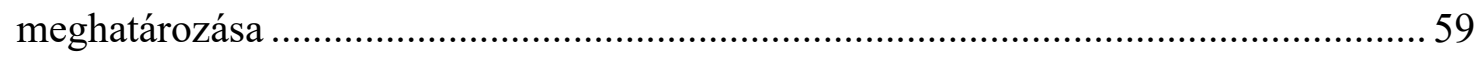

5.5.1.2. Illóolajok hatása az A. parasiticus mikotoxin termelésére................................ 61

5.5.2. A.parasiticus és A.nomius izolátumok tenyésztése folyadékban, az aflatoxin

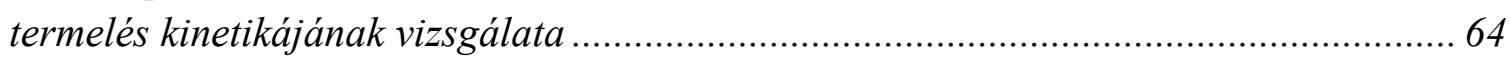

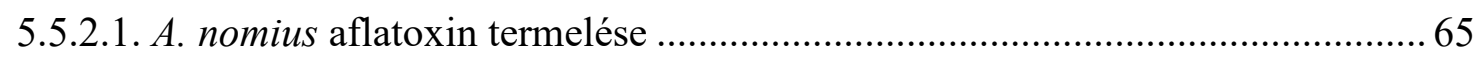

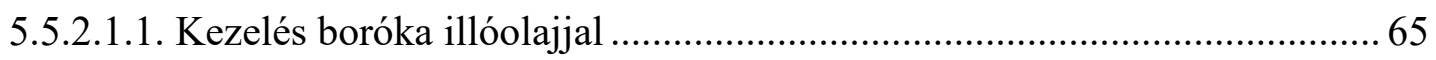

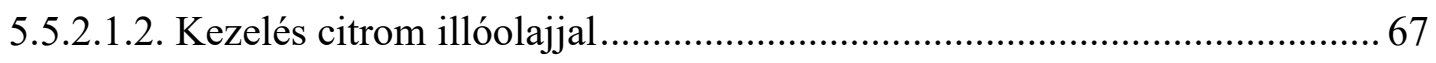

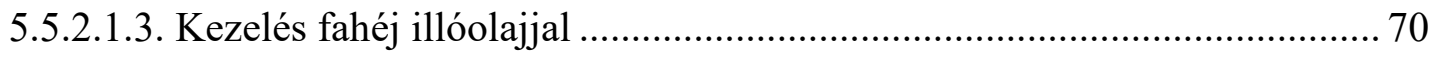

5.5.2.1.4. Kezelés majoránna illóolajjal ............................................................ 73

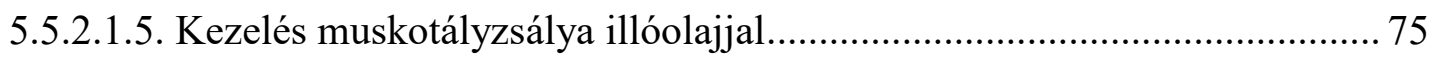

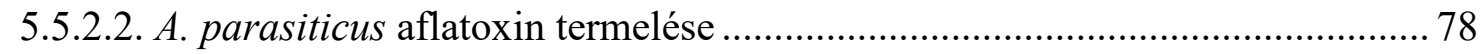

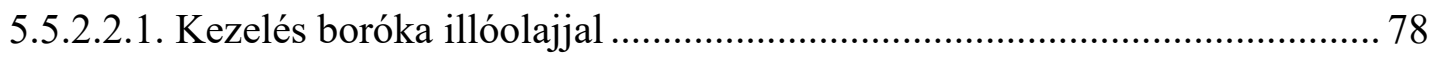




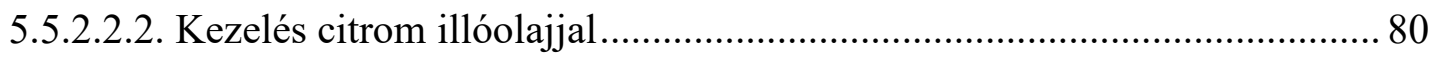

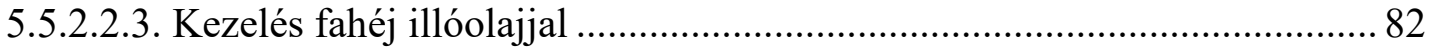

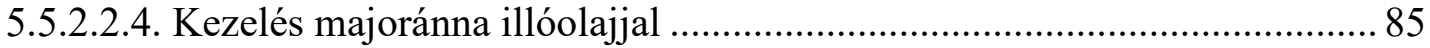

5.5.2.2.5. Kezelés muskotályzsálya illóolajjal........................................................ 87

5.6. A. parasiticus tenyésztése búza szubsztráton, az aflatoxin termelés vizsgálata..... 90

5.6.1. Búzaminták vízaktivitás értékei ...................................................................... 90

5.6.2. Az A. parasiticus által termelt aflatoxinok detektálása az illóolajos kezelések

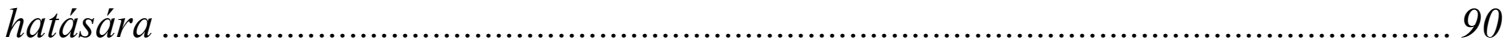

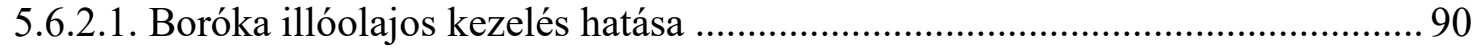

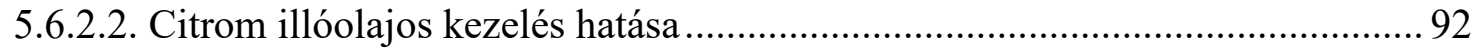

5.6.2.3. Fahéj illóolajos kezelés hatása .......................................................................... 93

5.6.2.4. Majoránna illóolajos kezelés hatása .......................................................... 94

5.6.2.5. Muskotályzsálya illóolajos kezelés hatása ................................................ 95

5.7. Illóolajok hatása a fonalasgombák morfológiájára .....................................................97

5.7.1. Elektronmikroszkópos vizsgálatok eredménye .................................................... 97

5.7.2. Morfológiai változások folyadékközegben történö tenyésztés esetén ..................... 98

6. ÖSSZEFOGLALÁS ....................................................................................................... 101

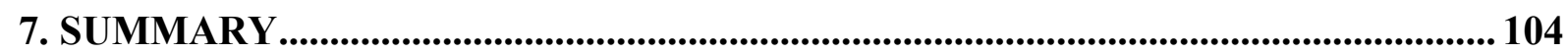

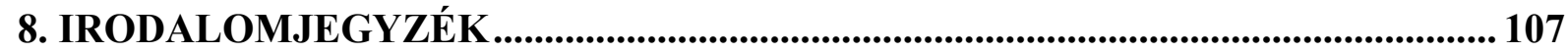

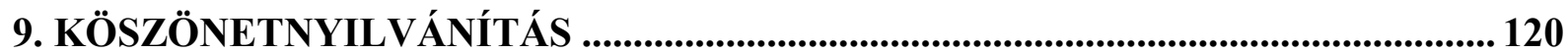




\section{Rövidítések jegyzéke}

AFB1: Aflatoxin B1

AFB2: Aflatoxin B2

AFG1: Aflatoxin G1

AFG2: Aflatoxin G2

AFM1: Aflatoxin M1

AFM2: Aflatoxin M2

DON: dezoxinivalenol (vomitoxin)

EFSA: European Food Safety Authority (Európai Élelmiszerbiztonsági Hivatal)

ELISA: enzyme-linked immunosorbent assay (enzim-kapcsolt immunszorbens módszer)

EO: Essential Oil (illóolaj)

FAO: Food and Agriculture Organization (Az Egyesült Nemzetek Szervezetének Élelmezésügyi és Mezőgazdasági Szervezete)

FAS: zsírsav szintetáz

FB1, FB2, FB3, FB4: Fumonizin toxinok

HPLC: High-Performance Liquid Chromatography (Nagy teljesítményü folyadékkromatográfia)

MEA: Malt Extract Agar (Malátakivonat-agar)

MIC: Minimal Inhibitory Concentration (minimális gátló koncentráció)

NOR: norsolorinsav

NRRL: Agricultural Research Service Culture Collection, USA

OTA: Ochratoxin A

PDA: Potato Dextrose Agar (burgonya-dextróz agar)

PKS: poliketid szintáz

ROS: Reaktív oxigén származék

RPM: revolution per minute (percenkénti fordulatszám)

SEM: Scanning Electron Microscope (pásztázó elektronmikroszkóp)

SZMC: Szeged Microbiology Collection (Szeged Mikrobiológiai Törzsgyüjtemény)

Gyógyszerészeti Hivatala)

TFA: trifluor-ecetsav 


\section{BEVEZETÉS}

A föld népességének növekedése és az ebből adódó élelmezési problémák világszerte egyre nagyobb kihívást jelentenek. Az ENSZ Élelmezésügyi és Mezőgazdasági Szervezetének (FAO) felmérése alapján évente kb. 1000 millió tonna élelmiszer szennyeződik mikotoxin-termelő fonalasgombákkal világszerte. Problémát jelent, ha a szennyezett agráripari termék emberi fogyasztásra vagy állati takarmányozásra kerül, hiszen hatalmas az egészségkárosító kockázatuk. A szennyezett, jelzett határértéket meghaladó mikotoxin tartalmú élelmiszert, takarmányt minden esetben meg kell semmisíteni. Ez óriási veszteséget jelent, egyrészt gazdasági szempontból, másrészt azért, mert világviszonylatban mintegy 842 millió ember nem jut elegendő élelmiszerhez.

$\mathrm{Az}$ élelmiszerellátás biztonsága (food security) egyre fontosabb feladat. Számos agrártermék (pl. gabonafélék, magvak, diófélék, gyümölcsök, zöldségek, füszerek) érintett a fonalasgombák és az általuk termelt mikotoxinok okozta szennyezettség kérdésében.

Számos biológiai, fizikai, kémiai hatásmechanizmuson alapuló módszert próbáltak már ki a mikotoxinok eltávolítására (pl. gamma-sugárzás, ózonkezelés, hőkezelés, savas-, lúgos kezelés, mikrobák és enzimek alkalmazása), de hatékonysági, gazdaságossági, technológiai szempontból ezek ma még nem jelentenek kielégítő megoldást. Döntő szerepe továbbra is a megelőzésnek van.

Napjainkban olyan anyagokra és módszerekre van szükség, amelyek megakadályozzák a fonalasgombák szaporodását és toxintermelését. Az új eljárásokkal szemben az az elvárás, hogy legyenek hatékonyak, gazdaságosak, gyorsan és könnyen alkalmazhatóak, továbbá ne jelentsenek környezeti és egészségügyi kockázatot.

A növényi eredetü illóolajok a szintetikus szerek jövőbeni alternatívái lehetnek, mivel antimikrobiális és antioxidáns hatásuk bizonyított és elismert.

Kísérleteink során ötféle illóolajat (boróka-, citrom-, fahéj-, majoránna-, muskotályzsálya olaj) teszteltünk ismert és gyakran előforduló Aspergillus, Fusarium és Cochliobolus fajok növekedésének gátlására. Megvizsgáltuk, hogy hogyan hatnak az illóolajok az Aspergillus parasiticus és az Aspergillus nomius fajok aflatoxin termelésére. Mivel napjainkban a mezőgazdasági termékek aflatoxin szennyezettsége kiemelt figyelmet kap, így a növekedés- és a toxintermelödés vizsgálatait búza szubsztráton is elvégeztük laboratóriumi körülmények között. 


\section{IRODALMI ÁTTEKINTÉS}

\subsection{Illóolajok}

\subsubsection{Az illóolajok története és jellemzése}

Az illóolajok olyan aromás, szobahőmérsékleten maradék nélkül elillanó folyadékok, amelyeket különböző növényi részekből (virágokból, rügyekből, magvakból, levelekből, kérgekből, gyümölcsökből, gyökerekböl) nyernek ki préselés, fermentálás, extrahálás és vízgőz-desztilláció segítségével. Ugyanazon növénynek más-más részéből nyert illóolaj hatása különböző is lehet (Temesvári 2003).

Az illóolaj név nagyon régi, a latin eredetü Quinta Essentia kifejezésre eredeztethető vissza, amelynek jelentése: a „tömény kivonat”, illetve „a lényeg”. Többnyire gyógyszerek aktív összetevőjének megnevezésére szolgált, később ugyanezt a megnevezést alkalmazták azokra az anyagokra is, amelyek a növények illatáért felelősek (Haagen-Smit 1961).

Már az ókori görögök és rómaiak is ismerték, és előszeretettel használták a drága illóolajokat, azonban ez természetesen csak egy szük réteg számára adatott meg. Főként testápolásra, illatosításra alkalmazták őket (Biegelbauer 1995). Kezdetben előállításuk az alábbi módszer szerint történt: a virágokat és a gyökereket olajokba keverték, üvegekbe helyezték, a napon felmelegítették, végül az illatos olajat elválasztották a szilárd részektől. Egy másik metódus szerint a növényi alapanyagokat borban áztatták, majd ezt követően vetették alá egyéb müveleteknek (pl. szürés). Már a Biblia is részletesen leírt olyan illatos, szentelt olaj recepteket, amelyeket az oltár, a gyertyatartók és az egyéb eszközök, illetve a papok felszentelésekor alkalmaztak. A termékek zömét Indiából és Kínából karavánok szállították Egyiptomba (Haagen-Smit 1961).

Az illóolajok a gyógyítás eszközeként is szerepet kaptak az egyiptomi, mezopotámiai, görög, római és kínai kultúrákban. Baktériumölő és konzerváló hatásuk miatt az egyiptomiak a halottak mumifikálására használták, míg a kínaiak és a hellének inkább kábító hatásukat részesítették előnyben (Biegelbauer 1995).

A becslések alapján 3000 illóolaj létezik, amelyek több mint 60, egyedileg meghatározható vegyületből állnak. Mintegy 300 illóolaj kereskedelmi forgalomban is megtalálható (Van de Braak és Leijten 1999, De Martino és mtsai. 2009). 


\subsubsection{Az illóolajok összetevöi}

Az illóolajok legtöbb aktív, antimikrobiális hatással bíró komponensét nehéz azonosítani, mivel az illóolajok különböző összetevők komplex keverékei (Delaquis és mtsai. 2002, Espina és mtsai. 2011), de egy adott illóolaj összetétele változhat a betakarítási időszak (évszak) vagy az alkalmazott extrakciós módszer függvényében is (Nannapaneni és mtsai. 2009, Djenane és mtsai. 2011).

A földrajzi helyzet, a tengerszint feletti magasság, a talaj adottságai, az öntözés mind befolyással bírnak az illóolajok fitokémiai összetételére és antioxidáns aktivitására. Az illóolajok magas minősége a betakarítás idejének optimalizálásával biztosítható (Kakaraparthi és mtsai. 2014). Formisano és munkatársai (2015) kimutatták, hogy az illóolajok és extraktumok mennyisége függ az edafikus tényezőktől, az éghajlati viszonyoktól és a növény genotípusától.

Az illóolaj hozamot jelentősen befolyásolja a növény fenológiai állapota (vegetatív szakasz, teljes virágzás, mag érésének szakasza), de meghatározó a növény kora, a levél kora, a levél pozíciója is (Gupta és Ganjewala 2015, Usano-Alemany és mtsai. 2016, Tahmasebi és mtsai. 2016). A kedvezőtlen környezeti feltételek korlátozhatják a növény fotoszintézisét és megváltoztathatják tápanyagfelvételét. Stressz hatására (pl. rossz időjárási körülmények, korlátozott tápanyagmennyiség) a növény fogékonyabbá válik a kártevőkkel és a kórokozókkal szemben. A hideg hónapok és a kevés napsütés következtében csökken az illóolaj termelődés (Pirbalouti és mtsai. 2013).

Usano-Alemany és munkatársai (2016) a levendulalevelü zsálya (Salvia lavandulifolia) illóolaj hozamát és annak minőségét tanulmányozták. Arra a következtetésre jutottak, hogy a növény illóolaja a vegetatív és a virágzó szakaszban nagyobb mennyiségben tartalmazott terpéneket, mint a mag érlelésének szakaszában, amikor jelentősen megnövekedett az oxidált származékok jelenléte.

Dorman és Deans (2000) kutatásai megerősítették, hogy az illóolajok antimikrobiális hatását az összetevőik határozzák meg, azaz függ az alapmolekulák és azok funkcionális csoportjainak strukturális konfigurációjától, valamint a komponensek közötti lehetséges szinergikus kölcsönhatásoktól.

A komponenseket általában két csoportba soroljuk, az eltérő bioszintetikus eredetük szerint. A fő csoportot a terpének és terpenoidok alkotják, a másik csoport pedig aromás összetevőket tartalmaz (Bakkali és mtsai. 2008, Jayasena és Jo 2013). A terpének 
szénhidrogének, amelyek a növényi sejt citoplazmájában szintetizálódnak, és több izoprén egységből állnak. Az oxigént tartalmazó terpéneket terpenoidoknak nevezzük.

Az illóolajokban kimutatható terpének közé tartozik a terpinén, limonén, szabinén és a pinén. A terpenoidok között előfordulnak alkoholok, észterek, aldehidek, ketonok, éterek és fenolok is. Az illóolajok legismertebb terpenoidjai közé tartozik a geraniol, mentol, linalool, citronellol, timol, karvakrol, geranil acetát, eugenil-acetát, geranial és a neral. Fenilpropanoidoknak tekinthetőek, aromás gyürüt tartalmaznak és kevésbé gyakoriak az alábbi vegyületek: fahéjaldehid, fahéjalkohol, eugenol, metil-eugenol és metil cinnamát (Ayala-Zavala és mtsai. 2007, Hyldgaard és mtsai. 2012). Az 1. ábra mutatja néhány fö illóolaj összetevő szerkezeti képletét.<smiles>CC1=CCC2CC1C2(C)C</smiles>

a-pinén<smiles>C=C(C)[C@H]1CC=C(C)CC1</smiles>

limonén<smiles>O=C/C=C/c1ccccc1</smiles>

fahéjaldehid<smiles>CC1=CCC(O)(C(C)C)CC1</smiles>

terpinen 4-ol<smiles>Cc1ccc(C(C)C)c(O)c1</smiles>

timol

1. ábra: Néhány fő illóolaj összetevő kémiai szerkezete.

A legtöbb illóolaj összetevő több módon is képes hatni, emiatt nehéz megjósolni, hogy az egyes mikoorganizmusok mutatnak-e arra érzékenységet vagy sem. Szükség van olyan alapos vizsgálatokra, amelyek az illóolaj összetevők hatásmechanizmusát és a környezettel való kölcsönhatásukat is tanulmányozzák (Hyldgaard és mtsai. 2012).

Számos kutatás bebizonyította, hogy az illóolajok és komponenseik antibakteriális hatást fejtenek $\mathrm{ki}$ in vitro körülmények között és az élelmiszerekben is az élelmiszerszennyező patogének ellen (Burt 2004). Az antibakteriális hatás elsősorban abban nyilvánul meg, hogy a citoplazmamembrán permeabilitása megnövekszik és ennek következtében a sejttartalom kiszivárog (Yamamoto-Ribeiro és mtsai. 2013). Minél hosszabb 
ideig van kapcsolatban az illóolaj és a mikroorganizmus, annál nagyobb lesz az intracelluláris elemeket érintő veszteség (De Oliveira és mtsai. 2010).

A fenolos komponensek tekinthetők a leginkább aktívnak. A Gram-pozitív mikroorganizmusok általában véve érzékenyebbek az illóolajokra, mint a Gram-negatívok (Burt 2004, Demuner és mtsai. 2011).

De Oliveira és munkatársai (2010) szerint az indiai citromfü (Cymbopogon citratus) és a citronella (Cymbopogon nardus) illóolaja (egyedül vagy kombinációban) új alternatívája lehet az ipari acél felületek Listeria monocytogenes elleni fertőtlenítésének. Ezek az illóolajok fö kémiai összetevőként monoterpéneket tartalmaznak. A monoterpének hatásmechanizmusa főként a sejtmembránt érintő toxikus hatásban nyilvánul meg (Sikkema és mtsai. 1995).

Egy korábbi munkánkban (Gömöri és mtsai. 2018a) két különböző évjáratú kakukkfü illóolaj antimikrobiáliss és biofilm-ellenes hatását vizsgáltuk. A 2013. évi betakarításból származó kakukkfü illóolaj fö összetevője a timol volt, míg a forró, csapadékos időjárással bíró, 2014. évből származó olaj esetében a timol prekurzora, a p-cimén jelent meg fő összetevőként. A megváltozott illóolaj összetétel számottevő változást eredményezett a kakukkfü illóolaj antimikrobiáliss és biofilm-ellenes hatásában. A timol egyedül jobb antimikrobiális hatással bírt, mint a p-cimén önmagában vagy a két összetevő kombinációjában.

\subsubsection{Az illóolajok alkalmazási területe, hatása}

Az illóolajok alkalmazásával csökkenthető az élelmiszerek mikrobatartalma, ebből adódóan a romlás is. Elönyük, hogy e hatás kifejtéséhez kis mennyiségben elegendőek. Gyógyszerek előállításában, az alternatív gyógyászatban és a természetes terápiákban is helyet kaphatnak (Teissedre és Waterhouse 2000, Soliman és Badeaa 2002, Burt 2004, Sokovic és Van Griensven 2006, Celiktas és mtsai. 2007, Politeo és mtsai. 2007).

A legtöbb illóolaj, patogénekkel szembeni antibakteriális hatását számos kutatás támasztotta alá (Lambert és mtsai. 2001), tanulmányok mutatták be, hogy hatékonyak a baktériumok által képzett biofilmek ellen is (Burt 2004, Kerekes és mtsai. 2013). A biofilmek kialakulása a baktériumok esetében gyakori és ebben a formában sokkal ellenállóbbá válnak az antimikrobiális fertőtlenítő szerekkel szemben (Prakash és mtsai. 2003). 
Gupta és munkatársai (2011) kísérleteikkel alátámasztották, hogy az illóolajok olcsó, biztonságos és hatékony alternatívái lehetnek a növényvédelem területén a szintetikus peszticideknek. Hatásosan alkalmazhatóak termeszek, gombák vagy a fonalférgek ellen.

Devkatte és munkatársai (2005) 38 növényi eredetü illóolajat vizsgáltak in vitro kísérletekben a Candida albicans négy izolátumával szemben. Kísérleteik során a tesztelt olajok közül 23 hatása volt ígéretes. Az alkalmazott olajok többsége már alacsony koncentrációban is fungicid hatással rendelkezett, ezek közül hét illóolaj (fahéj-, citromfü-, szegfüszeg-, japán menta-, geránium-, citromnád-, gyömbérfü-olaj) különösen hatékonynak bizonyult. Megállapították, hogy a növényi olajok jól használhatóak Candida-ellenes szerekként az azol-rezisztens törzsek esetén.

Dorman és Deans (2000) az illóolajok antibakteriális aktivitását vizsgálták 25 különböző baktérium nemzetségen. Ezek között előfordultak állati és növényi patogének, élelmiszerszennyezők, valamint romlást okozó baktériumok is.

Az élelmiszerekben alkalmazott füszerek kapcsán megállapítást nyert, hogy azok általában nincsenek jelen elegendő mennyiségben ahhoz, hogy antimikrobás tulajdonságuk kifejezésre jusson. Ezen felül a füszerek gyakran maguk is baktériumokkal és gombaspórákkal fertőzöttek (Dorman és Deans 2000, Burt 2004).

$\mathrm{Az}$ illóolajokat az élelmiszeripar elsődlegesen aromaanyagokként alkalmazza. Potenciális élelmiszertartósítóknak tekinthetők, mivel hatékonynak bizonyultak az élelmiszereket szennyező baktériumok és a mikotoxinokat termelő gombák ellen (Nguefack és mtsai. 2004).

Az illóolajok élelmiszerekben történő alkalmazásának gátat szab azok erős aromája, amely nem kívánatos változást okozhat az ételek ízében és illatában. Ez a probléma leküzdhető az illóolajok kombinációjával, amely során a szinergikus vagy additív hatás csökkenti a szükséges illóolaj mennyiséget (Burt 2004). Az illóolajok gőztérben történő alkalmazása hatással van a spórázásra és a hifák növekedésére. Az illóolajok alkamazásakor a konídiumok inaktiválása a gátlás kulcsa (Reyes-Jurado és mtsai. 2014).

Espina és munkatársai (2013) az Escherichia coli O157:H7 és a Listeria monocytogenes inaktiválását célozták meg illóolajok és összetevőik segítségével, nagy hidrosztatikus nyomás alkalmazása mellett. Eredményeik rávilágítottak arra, hogy az illóolajok és komponenseik inaktiválhatják a patogéneket a nagy nyomással kombinált kezeléseknél. Az eljárás alkalmazását főként folyékony élelmiszerek (pl. gyümölcslevek) gyártásánál javasolják. 
Ebani és munkatársai (2016) kísérleteikben hatékonynak találták a szegfüszeg, a fahéj és az oregano illóolaját az A parasiticus valamint a Fusarium moniliforme ellen, mivel az illóolajok a micéliumok növekedését és a fonalasgombák mikotoxin termelő képességét gátolták.

Gill és munkatársai (2002) megállapították, hogy az illóolajok antimikrobás hatása in vitro körülmények között jobban érvényesül, mint az élelmiszeripari termékek esetében. Ezt azzal magyarázták, hogy az élelmiszerek több tápanyagot tartalmaznak, mint a laboratóriumi tápközegek. Az olyan tápanyag gazdag mátrixokban, mint például a húsok, húsipari termékek, a mikrobapopulációk rezisztenciája a különböző stressztényezőkre megnövekedhet. Számos egyéb ok lehet, amely az élelmiszerekben az illóolajok antimikrobiális hatását befolyásolhatja (Juven és mtsai. 1994), ide tartozik a termékek zsírtartalma, a pH vagy a víztartalom is (Laranjo és mtsai. 2017).

Az élelmiszeripari termékekben az illóolajok alkalmazása nem megszokott, legfőképp a főtt, húsipari készítmények esetében jelent korlátot. Dussault és munkatársai (2014) sonkáknál alkalmaztak kakukkfü- és fahéj illóolajat, mely a L. monocytogenes szignifikáns csökkenését eredményezte. A mortadella eltarthatóságát sikerült megnövelni rozmaring és kakukkfü illóolaj használatával (Viuda-Martos és mtsai. 2010a), és ugyanezt a hatást érték el bolognai szószokhoz hozzáadott oregano illóolajjal (Viuda-Martos és mtsai. 2010b). GarcíaDíez (2016) és kutatócsoportja száraz kolbászoknál alkalmazott fokhagyma és oregánó illóolajat. Az alkalmazott illóolajok hatékonynak bizonyultak a L. monocytogenes, a Salmonella ssp. valamint a $S$. aureus ellen is.

Az illóolajok más technológiákkal (mint például termikus kezelés, magas hidrosztatikus nyomás, pulzáló elektromos mező, aktív csomagolás) történő társítása szintén kutatott terület (Espina és mtsai. 2013, 2014).

Kísérletek történtek húsipari starterkultúrák illóolajokkal kombinált alkalmazására is. A vizsgált illóolajok (fahéj, szegfüszeg, gyömbér, ánizs) szinergistaként, a strarterkultúrákkal együtt hatékonyan gátolták a biogén aminok felhalmozódását és az enterobaktériumok növekedését (Lu és mtsai. 2015). Tejtermékek gyártásánál, illóolajok használatakor számolni kell a tejsavbaktérium populáció csökkenésére, a savanyodás csökkent mértékére, valamint arra, hogy az illóolajok gátolják a termékek jellegét biztosító oxidatív- és fermentációs folyamatok lezajlását (Olmedo és mtsai. 2013, Asensio és mtsai. 2015).

A zöldségek és a gyümölcsök, mint romlandó élelmiszerek többnyire rövid eltarthatósági idővel bírnak. Romlásukat és tömegvesztésüket főképp a fonalasgombák 
aktivitása okozza. Az előforduló problémák egy része megoldható azzal, hogy a betakarítást követően, a tárolás, a szállítás alatt alacsony hőmérsékletet biztosítanak. Az eltarthatóság megnövelését célozza a módosított vagy ellenörzött légtér alkalmazása (Laranjo és mtsai. 2017).

A zöldségek esetében, az illóolajok alkalmazhatóak a mosóvízhez történő hozzáadással is (Burt 2004). Kísérletek történtek kakukkfü- és szegfüszeg illóolaj alkalmazására, földieper csomagolásának légterében, minek hatására a fonalas gombák jelenléte kimutathatóan csökkent (Laranjo és mtsai. 2017)

Az illóolajokat újabban alkalmazzák csemegeszőlőknél is az eltarthatóság megnövelésére. Új csomagolásokat fejlesztettek ki, amikor a szőlőt két különböző réteg alkalmazásával csomagolták, többek között eugenol-timol-karvakrol elegy hozzáadásával. Az új csomagolás hatására a mikrobaszám drasztikusan csökkent, a rothadás pedig jelentősen visszaszorult (Valero és mtsai. 2006, Gullién 2007). A csemegeszőlőnél a módosított légterü vagy aktív csomagolás kialakítása, a csomagoláson belül eugenol vagy timol alkalmazása, csökkentette a minőségi veszteségeket, alacsonyabb spóraszámot eredményezett (Valero és mtsai. 2006).

A felületre felvitt, légtérben alkalmazott illóolajok a direkt alkalmazásokkal ellentétben nem, vagy csak kissé változtatják meg a termék ízét, organoleptikus tulajdonságait (Quesada és mtsai. 2016). Az innovatív csomagolások egyik új formája lehet, amikor a húsok csomagolásába olyan párnát építenek be, mely illóolajjal van átitatva (Oral és mtsai. 2009). Az illóolajok alkalmazása kapcsán kifejlesztés alatt állnak ún. „ehető filmek” is, mely a zöldségek, gyümölcsök, magvak, húsok, halak felületére juttatva növelni képes azok eltarthatóságát (Mihai és Popa 2013, Munhuweyi és mtsai. 2017)

\subsubsection{A felhasznált illóolajok bemutatása}

\subsubsection{Borókaolaj}

A boróka (Juniperus communis) Európában, Észak-Amerikában, Észak-Ázsiában és Észak-Afrikában honos. Fájából, bogyóiból vízgőz-desztilláció segítségével nyerik ki az illóolajat. Élettani hatásait tekintve vízhajtó, fertőtlenítő, élénkítő és húgysavoldó hatású (Biegelbauer 1995). A borókabogyóból nyert illóolaj fő összetevőiként $\alpha$-pinént, $\beta$-pinént, szabinént, limonént és mircént mutattak ki Pepeljnjak és munkatársai (2005) gázkromatográfia segítségével. Eredményeik szerint a boróka illóolaja hasonló 
antimikrobiális hatással bírt a Gram-pozitív és Gram-negatív baktériumokra, valamint a mikroszkópikus gombákra. A legerősebb gombaölő hatását a Candida fajoknál észlelték.

\subsubsection{Citromolaj}

A citrom (Citrus lemon) Elö-Indiában őshonos. A Földközi tenger vidékén és más trópusi vidékeken termesztett fa gyümölcsének héjából préseléssel nyerik ki az illóolajat (Biegelbauer 1995). Kamaliroosta és munkatársai (2016) négy különböző citrusféle héjából nyert illóolaj kémiai összetételét vizsgálva arra a megállapításra jutottak, hogy ezek mindegyike döntő többségben limonént tartalmaz. A Citrus limetta (lime) héjából nyert illóolajból 18 komponenst különítettek el: a limonén 49,79\%, a xantotoxin 12,62\%, a 6,6dideutero-nonen-1-ol-3 10,20\% és a 4-vinyl-2-metoxy-fenol 5,20\%-ban volt jelen. A Citrus limon (közönséges citrom, európai citrom) esetén a limonén jóval nagyobb mértékben $(83,03 \%)$ volt jelen.

\subsubsection{Fahéjolaj}

A fahéj (Cinnamomum zeylanicum) Srí Lanka szigetén honos fa, de termesztik a Szunda-szigeteken, Nyugat-Indiában és Brazíliában is. A fa kérgéből vízgőz-desztillációval nyerik ki az illóolajat (Biegelbauer 1995). A kéreg illóolaj tartalma csupán 1,25\%. Kazemi és Mokhtariniya (2016) a fahéjolaj 21 komponensét határozta meg. Összetételének 52,3\%-át a fahéjaldehid tette ki, ezt követte az $\alpha$-kopaén $(11,42 \%)$ és a $\delta$-kadinén $(6,25 \%)$.

Chang és munkatársai (2001) kilenc baktériumtörzset vizsgálva megállapították, hogy a fahéjolaj alkotóelemei közül a fahéjaldehid rendelkezik a legerösebb antibakteriális hatással, ami a jelen lévő konjugált kettős kötésnek és a gyürün kívüli hosszú szénláncnak tulajdonítható.

\subsubsection{Majoránnaolaj}

A majoránna (Origanum majorana) Perzsiából került a Földközi-tenger mellékére, Európa-szerte termesztik. Az illóolajat a friss növény lepárlása útján nyerik (Biegelbauer 1995). A növény illóolaj tartalma mindössze 1\%. A kis hozama miatt a drága olajok közé tartozik. Vera és Chane-Ming (1999) a majoránna illóolaj 45 komponensét különítette el gázkromatográfiás vizsgálat segítségével. Terpinen-4-ol (38,4\%), cisz-szabinén hidrát (15,0\%), p-cymén $(7,0 \%)$ és $\gamma$-terpinén $(6,9 \%)$ jelentek meg az illóolaj fö összetevőiként. 
A népi gyógyászatban feszültségoldó, nyugtató, görcsoldó, izzasztó, fájdalomcsillapító hatása miatt kedvelt. Nehezen gyógyuló sebek jól kezelhetők majoránna illóolajjal (Temesvári 2003).

\subsubsection{Muskotályzsálya olaj}

A muskotályzsálya (Salvia sclarea) a Földközi-tenger vidékén honos; föld feletti részéből, a növény virágos, felső hajtásaiból nyerik ki az illóolajat vízgőz-desztillációval. A természetgyógyászok kiváló antidepresszáns hatást tulajdonítanak neki, de nagy dózisban kábító hatású is lehet. Elsősorban rossz emésztés, légzőszervi betegségek, magas vérnyomás és bőrgyulladások kezelésénél alkalmazható (Biegelbauer 1995). Az olaj fő komponenseként linalool, linalil acetát, terpineol, neril acetát, geraniol, geranil acetát, nerol és szklareol mutatható ki (Souleles és Argyriadou 2008).

\subsection{Tömlősgombák}

\subsubsection{A fonalasgombák jelentösége}

A fonalasgomba elnevezés nem rendszertani fogalom, hanem a hasonló megjelenésű és tulajdonságú gombák gyüjtőneve, amely nagyon különböző morfológiájú, szaporodású és életmódú fonalas gombákra vonatkozik. Ezek rendszertani rokonsága olykor nagyon távoli (Deák és mtsai. 2006). A mikroszkópikus gombák jelenléte negatív hatást gyakorol az élelmiszerekre, mivel rontja azok érzékszervi tulajdonságait, illetve számolni kell tápértékük csökkenésével is. A növényi alapanyagok szubsztrátként szolgálhatnak a fonalasgombák növekedéséhez, mikotoxinjaik termeléséhez. A fonalasgombák aerob, heterotróf szervezetek. A tápanyagok oxidatív lebontásának fö módjai a hexóz-monofoszfát út és a citromsavkör. Hőmérsékleti igényük szerint többségében mezofilek és kedvelik a savas pH-t (Deák és mtsai. 2006).

A globális felmelegedés erősen befolyásolhatja a mikotoxin-termelő fonalasgombák földrajzi elterjedését. A klímaváltozás, különösen az extrém forró nyarakon, a termotoleráns fajok növekvő jelenlétét eredményezi a mérsékelt éghajlathoz tartozó régiókban, beleértve Közép-Európát is (Tóth és mtsai. 2013).

Élelmiszerbiztonsági okokból napjainkban a mikotoxinok a figyelem középpontjában állnak. Növekszik az igény a könnyen alkalmazható, mikotoxin-csökkentő stratégiák kidolgozására (Naeini és mtsai. 2010). 


\subsubsection{A kísérletekbe bevont fonalasgombák bemutatása}

\subsubsection{Az Aspergillus nemzetség}

A fonalasgombák közé tartozó Aspergillus nemzetség tagjai között megtalálhatóak a közönséges penészek és a humán patogének is. Először 1729-ben Pier Antonio Micheli, olasz botanikus írta le a nemzetséget. A mikroszkóp alatt látott konídiumtartók képe a kutatót a szenteltvíz-tartóra (latinul aspergillum) emlékeztette (Bennett 2010). Rendszertanilag az aszkuszos fonalasgombák Eurotiales rendjébe tartoznak. Ebbe a nemzetségbe több mint 350 faj tartozik (Brandl és Andersen 2017). Leggyakoribb előfordulásuk a trópusi, szubtrópusi területeken jellemző (Gourami és Bullerman 1995). Az Aspergillusok fontos szerepet töltenek be a szervesanyag-körforgásban, természetes környezetet jelent számukra többek között a komposzt vagy a bomló avar (Darvas 2004). Széles hőmérsékleti tartományban képesek növekedni $\left(6-55^{\circ} \mathrm{C}\right)$, viszonylag alacsony relatív páratartalom mellett, és a szerves anyagok széles skáláját tudják tápanyagforrásként hasznosítani. A telepeken képződött nagyszámú konídium környezetbe (levegőbe) kerülése szintén segíti elterjedésüket (Bennett 2010).

Az Aspergillus nemzetség körülbelül egyharmadára az ivaros, kétharmadára az ivartalan szaporodás jellemző (Geiser 2009). A legtöbb Aspergillus faj (pl. Aspergillus flavus és A. parasiticus) kizárólag ivartalan spórákat, ún. konídiumokat képez (2. ábra), ezzel szemben más fajok (pl. Aspergillus nidulans) a konídiumok mellett ivaros spórákat, ún. aszkospórákat is termelnek (Bennett 2010)

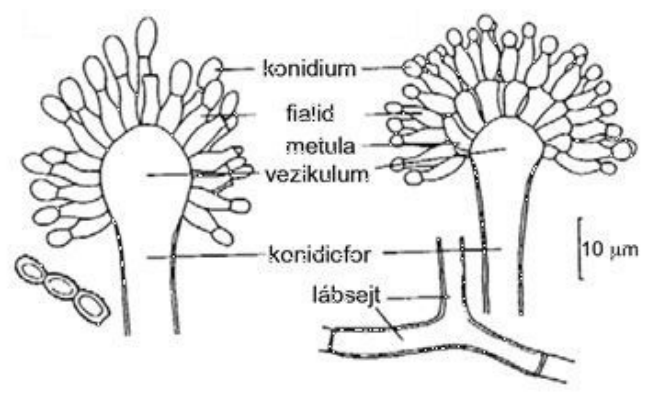

A

B

2. ábra: Az Aspergillus fajok jellegzetes konidiumfejének szerkezete.

A) Egysoros fej (A. parasiticus) B) Kétsoros fej (Aspergillus niger)

(Deák és mtsai. 2006).

Több Aspergillus faj termel másodlagos metabolitokat, amelyek felhasználhatóak az iparban is. Így például az Aspergillus terreus-t az ipari gyakorlatban lovasztatin termelésére használják, ami a koleszterinszint-csökkentő gyógyszerek hatóanyaga, de bizonyos rákos 
daganatok kezelésében is hatékony (Seenivasan és mtsai. 2008). A citromsav mint primer metabolit ipari előállítására főként az Aspergillus wentii-t és az A. niger-t alkalmazzák (Max és mtsai. 2010). Az A. niger törzseit gyakran használják különféle enzimek (pl. $\beta$-glükozidáz, cellobiohidroláz, $\beta$-xylozidáz, $\alpha$-arabinofuranozidáz és $\beta$-galaktozidáz) ipari előállítására (Hu és mtsai. 2011). Az aflatoxinokat nem termelő Aspergillus oryzae, Aspergillus sojae és az Aspergillus tamarii fajok a tradicionális ázsiai fermentált termékek előállításánál játszanak szerepet (Rodrigues és mtsai. 2007).

Az Aspergillus fajok a mezőgazdaságban és az élelmiszeriparban komoly károkat is okozhatnak. Mikotoxinjaik veszélyt jelentenek mind az állatok, mind az ember egészségére. Az Aspergillus-ok közül a legsúlyosabb problémát az A. flavus, A. parasiticus és az A. nominus törzsek okozzák mikotoxin termelésük miatt (Olsen 2008).

Kísérleteinkben hat Aspergillus izolátumot vizsgáltunk, amelyek közül az A. parasiticus aflatoxin termelése kapott kiemelt szerepet, tekintettel arra, hogy az egyik fö aflatoxin termelő törzsnek tartják (John 2008).

Az $A$. parasiticus egy növényi patogén, a Flavi szekció képviselője (3A. ábra). Az alábbi toxinokat termeli: aflatoxin B1, B2 és G1, G2 (AFB1, AFB2, AFG1, AFG2) (Schmidt-Heydt és mtsai. 2008), ochratoxin A (OTA) (Dimitrokallis és mtsai. 2008). Először a Hawaii szigeteken található cukornádról izolálták (Rodrigues és mtsai. 2007), de megtalálható a talajban, a betárolt, valamint a termőterületen lévő kukoricán, gyapotmagon, földimogyorón is (Yin és mtsai. 2008).

Az A. nomius (3B. ábra) szintén a Flavi szekció tagja, B és G típusú aflatoxinok előállítására képes (Moore és mtsai. 2015), megjelenését tekintve hasonlít az A. flavus-hoz. Azeez és munkatársai (2016). Kiemelt figyelmet érdemel, hiszen humán infekciót okoz (Tam és mtsai. 2014). Malayziában az A. nomius által termelt 46 másodlagos metabolitot mutattak ki, köztük telített és telítetlen szénhidrogéneket, alkoholokat és alkil halogenideket. Kurtzman és munkatársai (1987) rovarokról és mezőgazdasági termékekről izolálták az Amerikai Egyesült Államokban. Olsen és munkatársai (2008) a brazil dión, Ito és munkatársai (1998) pedig japán tea ültetvények talajáról és selyemhernyó ürülékből is izolálták. A telepek széle, ahol a fiatal spórák találhatóak fehér (Azeez és mtsai. 2016), az érett spórák pedig világos narancs-barna színűek (Ito és mtsai. 1998). A konídiumok gömbölyüek vagy gömbölydedek, durva felületet képeznek (Olsen és mtsai. 2008). 

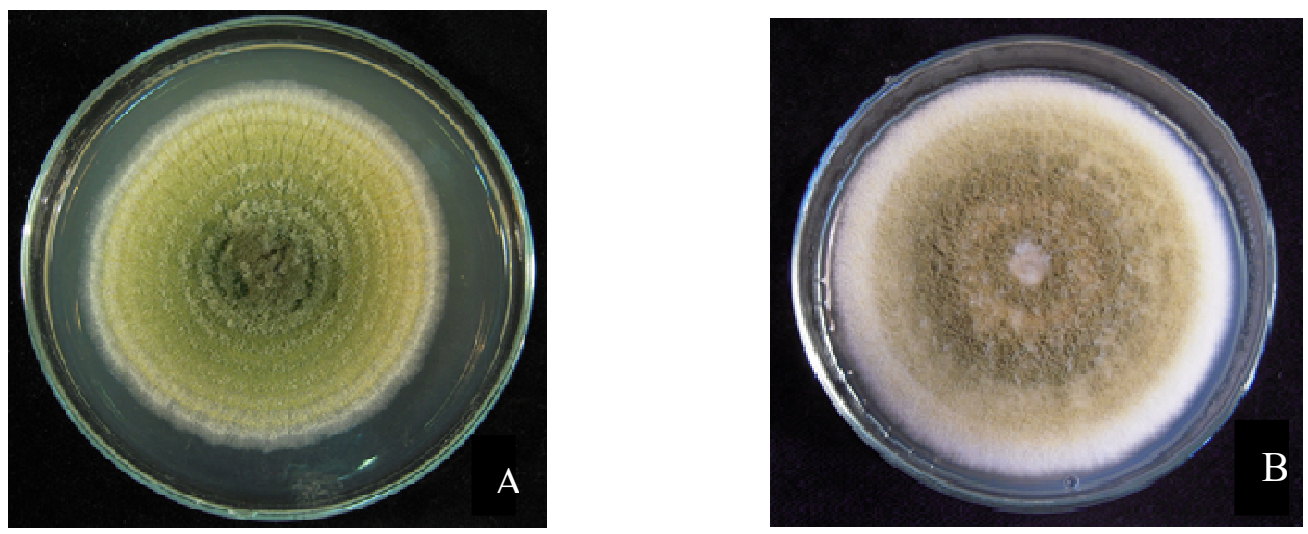

3. ábra: A. parasiticus (A) és A. nomius (B) telepek malátás táptalajon, 10 napig, sötétben történő inkubációt követően

Az Aspergillus albertensis ochratoxin A-t és B-t képez (Varga és mtsai. 2002), és elsősorban a gabonaféléket és a földimogyorót szennyezi (4A. ábra).

Az Aspergillus westerdijkiae (4B. ábra) az Aspergillus nemzetség Circumdati szekciójának egyik legjelentősebb OTA-t előállító faja (Aldred és mtsai. 2008). Különböző mezőgazdasági termékek, gyümölcsök (narancs, szőlő) és egyéb élelmiszerek (kávé, sör, bor, tej) OTA szennyezettségéért felelős. Megtalálható a háziporban és a beltéri levegőben is (Han és mtsai. 2016). Általában a növényi eredetű, szénben gazdag élelmiszer-mátrixokban jelent nagy kockázatot, de veszélyt jelent a húskészítményekre is (Vipotnik 2017). A fonalasgomba számára az OTA termeléshez optimális körülmények: 0,94-0,97 közötti vízaktivitás és 20$25^{\circ} \mathrm{C}$ közötti hőmérséklet. 0,85 alatti vízaktivitás esetén a faj nem termel kimutatható OTA mennyiséget.
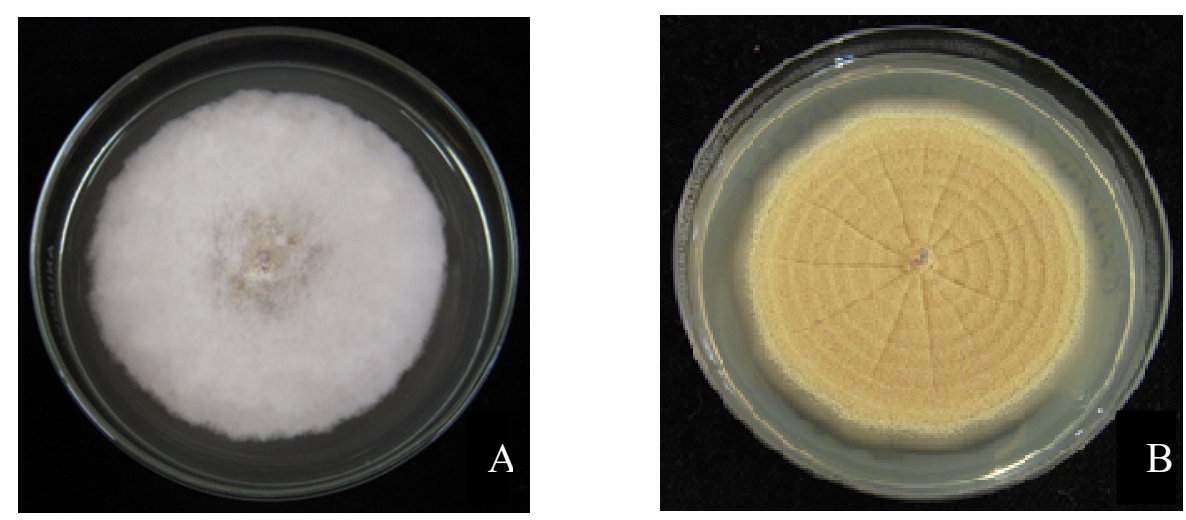

4. ábra: A. albertensis (A) és A. westerdijkiae (B) telepek. malátás táptalajon, 10 napig, sötétben történő inkubációt követően 
Az Aspergillus longivesica az Aspergillusok Clavati szekciójának képviselője, amely ribotoxin (riboszóma inaktivátor fehérje) (Varga és Samson 2008) és patulin termelőként is ismert (Puel és mtsai. 2010) (5A. ábra).

Az Aspergillus awamori fermentációs folyamatokban is alkalmazott mikroorganizmus (Max és mtsai. 2010) (5B. ábra). OTA-t (Dalcero és mtsai. 2002), valamint fumonizineket termel (Varga és mtsai. 2010). Más fekete Aspergillusokkal együtt előfordul dión, füszereken (chili, pirospaprika, füszerkeverékek) és gabona magvakon, továbbá megjelenik magas hőmérsékleten tárolt vöröshagymán is (Szigeti és mtsai. 2012). Az A. awamori citromsav előállítására képes, a keményítőt képes cukrokká bontani. Morfológiáját tekintve hasonlít az $A$. niger-hez és több közös enzimet termelnek.
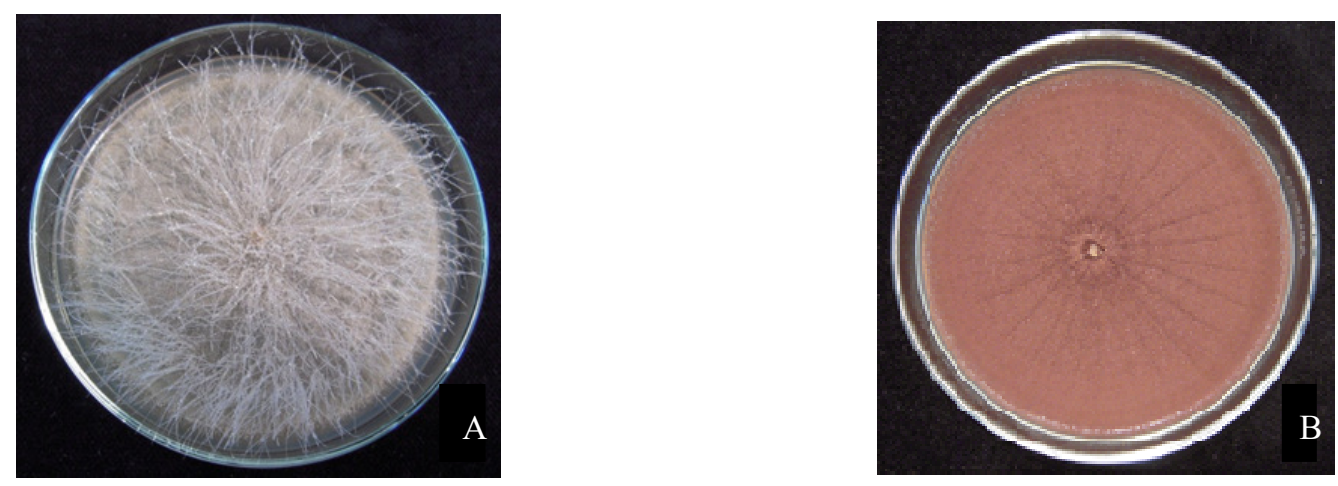

5. ábra: A. longivesica (A) és A. awamori (B) telepek. malátás táptalajon, 10 napig, sötétben történő inkubációt követően

\subsubsection{Fusariumok}

Számos Fusarium faj növénypatogén, mások szaprobionták, legtöbbjük előfordul a talajban. A Fusarium fajok leggyakrabban gabonaféléken és olajos magvakon fordulnak elő, a kukorica, a búza, az árpa és az ezekből készített termékek gyakran fertőzöttek. A termés- és minőségi problémákon túl a toxinszennyezés jelenti a legnagyobb kárt. A Fusarium fajok termelik az ismert mikotoxinok mintegy harmadát, köztük a zearalenont (F-2 toxint), a trichotecéneket (T-2, HT-2 toxin, dezoxinivalenol (DON), deacetoxiscirpenol) és a fumonizineket (FB1-FB6) (Deák és mtsai. 2006).

A Fusarium fajok meghatározásánál alapvető a makro- és a mikrokonídiumok jellemzése. Burgess és munkatársai (1994) Ausztráliában kiadott útmutatója alapján az egyes Fusarium fajok meghatározásánál, azonosításánál támpontot jelent a makro-, illetve 
mikrokonídiumok formája, a mikrokonídiumok, klamídiospórák jelenléte vagy hiánya. A telepek mérete, alakja, színe, a táptalaj pigmentációja szintén fajspecifikus.

A makrokonídiumok a sporodochiumokban képződnek, orsó vagy sarló alakúak, színtelenek, nagy tömegben rózsaszínủek (6. ábra). A légmicéliumokon keletkező mikrokonídiumok oválisak, színtelenek, nagy tömegben szintén rózsaszínűek. A Fusarium nemzetségbe nagyon sok faj tartozik, melyek közül egyes fajok egy-egy növényfajra specializálódtak: pl. a Fusarium oxysporum f. sp. cepae a hagymára (Glits és Folk 2000).

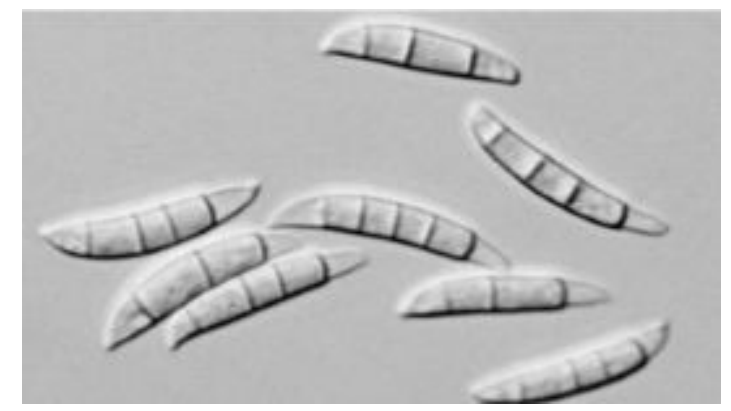

6. ábra: Fusarium culmorum makrokonídiumai (Leslie és Summerell 2006).

A növényi patogén Fusarium graminearum (teleomorf alak: Gibberella zeae) felelős a búza és az árpa kalászfuzáriumáért, jelentős veszteségeket okozva a terméshozamban. Termelt mikotoxinjai a fehérje bioszintézist gátló deoxinivalenol (DON) és az ösztrogén hatású zearalenon, rontják az élelmiszerek és takarmányok minőségét (Yang és mtsai. 2013).

A F. graminearum csak makrokonídiumokat képez az egyedülálló vagy többszörösen megjelenő fialidokon. A tiszta tenyészetben mikrokonídiumok nem fordulnak elő (Zheng és mtsai. 2012). A makrokonídiumok viszonylag vékonyak, mérsékelten hajlottak, banán alakúak és közepes hosszúságúak. A konídiumok több szeptummal tagoltak, gyakran megfigyelhető lábsejt is. Kedvező feltételek esetén a konídiumok aszkospórákat képeznek (Goswami és Kistler 2004). Laboratóriumi körülmények között, Potato Dextrose Agarra (PDA) oltva a tenyészetben a sporodochiumok lassan, szórványosan alakulnak ki, fóként az agar felszínén, színük halvány narancssárga. A gomba a glükózt hasznosítja szénforrásként. A sejtfal heterogén összetétele különösen fontos a $F$. graminearum patogenitása szempontjából, mivel összetett fehérjéket tartalmaz az elektron-transzport számára, valamint fontos enzimeket a kitin lebontásához (Shi és mtsai. 2008).

A szántóföldön hagyott, a talajban elfekvő, előző évi fertőzött növényi maradványok lehetnek a kalászfuzáriózis fertőzés fő forrásai. A F. graminearum (7. ábra) a kifejezetten 
meleg (nappal akár $20-27^{\circ} \mathrm{C}$ közötti) hömérsékletet kedveli. A fertőzőanyag (ivartalan vagy ivaros spóraformák) terjesztésében szerepe van a szélnek. A fertőzés létrejöttének feltétele a tartósan magas, akár 100\%-os páratartalom. A fertőzés következtében a szemek kisebbek lesznek (ezerszem tömeg csökken), a kalászok, illetve azok egy része kivilágosodik (Békési 2010). Magyarországon, a nagy járványok idején, egyértelmű a $F$. graminearum rendkívüli, erőteljes dominanciája (Békési 2014).

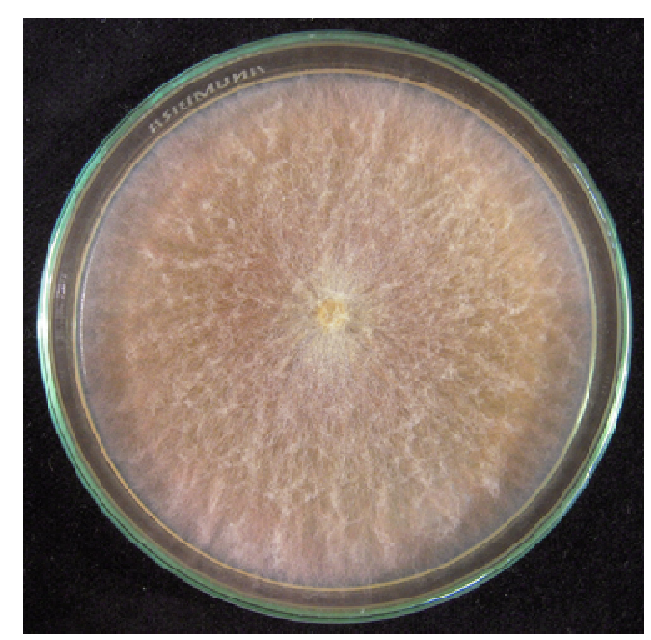

7. ábra: F. graminearum. telep PDA táptalajon, 10 napig, sötétben történő inkubációt követően

A $\boldsymbol{F}$. culmorum (8A. ábra) a $F$. graminearum-hoz képest kevésbé melegigényes, elsősorban a búza, árpa, zab, rozs, kukorica, cirok és a füfélék veszélyeztetettek, viszont izolálták már cukorrépáról, lenről, babról, borsóról, spárgáról, vörös lóheréről, komlóról, sőt burgonyagumóról is. A makrokonídiumok viszonylag rövidek és robusztusak, vastag falúak, íveltek, tompa apikális sejttel. Mikrokonídium nem fordul elő, a klamidospórák oválisak, gömbölyüek. A telepek PDA-n nagyon gyorsan nőnek (1,6-2,2 cm/nap), amennyiben biztosított számára az optimális $25^{\circ} \mathrm{C}$-os hőmérséklet. A micéliumok PDA-n pelyhes, fehéres, világossárga vagy piros színűek. A táptalajt szürkés-rózsaszín, kárminpiros, burgundivörös színüre változtatják (Scherm és mtsai. 2013). A F. graminearum-hoz hasonlóan B típusú trichotecéneket (DON, NIV) és zearalenont termel (Ferrigo és mtsai. 2016).

A Fusarium verticillioides (8B. ábra) elsősorban a kukoricát és más szántóföldi növényeket (köles, cirok, rizs) fertőzi. Nagy veszélyt jelent meleg, száraz időjárás esetén. A betegség tünetei nagyon változóak, egyes esetekben tünetmentesek maradnak, más esetekben viszont a fertőzöttség a növény minden részére kiterjedhet (Oren és mtsai. 2003). 
Megjelenésére a növény csírázásától kezdve, a betakarításkor és az azt követő időszakban is számítani kell. A micéliumok először fehér színüek, majd később ibolyaszínüvé változnak (Deepa és Sreenivasa 2017). A F. verticillioides haploid micéliumként növekszik, a hifák megnyúlnak és kétféle aszkémiás spórát, mikro- és makrokonídiumokat is képeznek (Zheng és mtsai. 2012). A makrokonídiumok hosszú, vékony, egyenes formátumúak, vékony fallal rendelkeznek, 3-5 részből állnak (Leslie és Summerell 2006). A nagy mennyiségben termelődő mikrokonídiumok ovális alakúak, a klamidospórák pedig hiányoznak. A mikotoxinok közül a $F$. verticillioides fumonizineket (FB1, FB2, FB3, FB4) termel, amelyek állatoknál, főként lovaknál és sertéseknél, okoznak komoly megbetegedéseket. A toxinok az idegsejteket károsítják azáltal, hogy gátolják a szfingolipid bioszintézist (Deepa és Sreenivasa 2017).
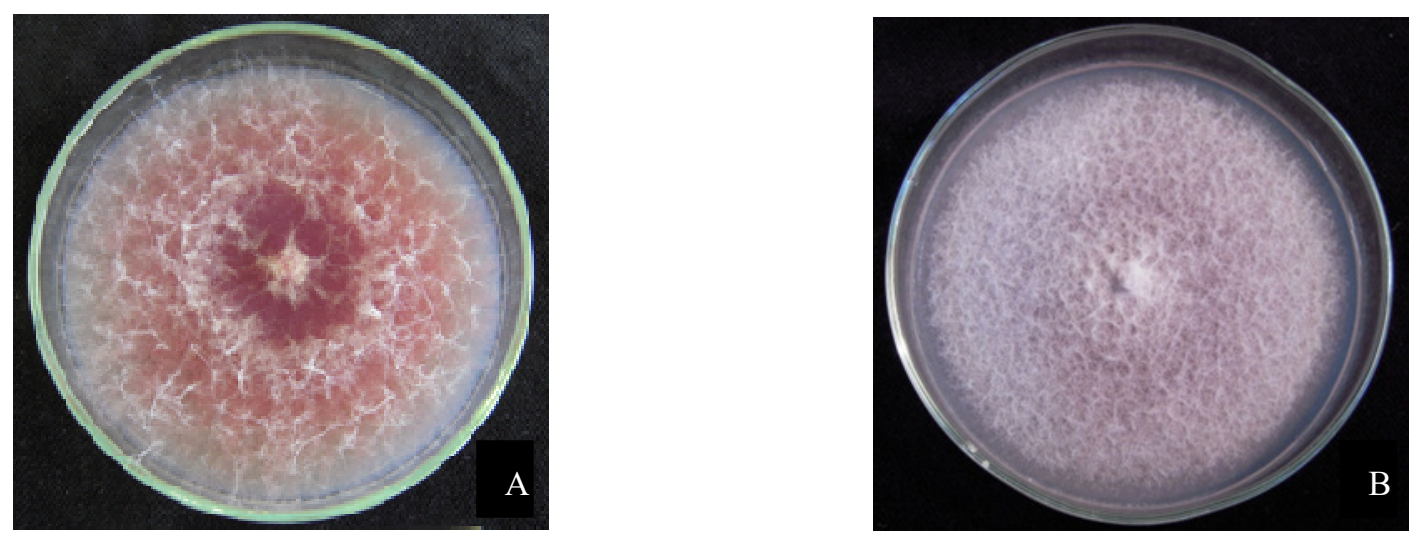

8. ábra: F. culmorum (A) és $F$. verticillioides (B) telepek. PDA táptalajon, 10 napig, sötétben történő inkubációt követően

\subsubsection{A Cochliobolus nemzetség}

A Cochliobolus nemzetségnek mintegy 55 faja ismert. A Cochliobolus hawaiiensis-t Európában kevésbé kutatják, mivel a meleg éghajlati körülmények (pl. India, USA délnyugati része) kedveznek számára (Gautier és mtsai. 2015) (9. ábra). Növénypatogén, amely súlyos termésveszteséget okoz világszerte. Szürke, sötétbarna vagy fekete teleppel jelenik meg, Ttoxint termel (Manamgoda és mtsai. 2011). 


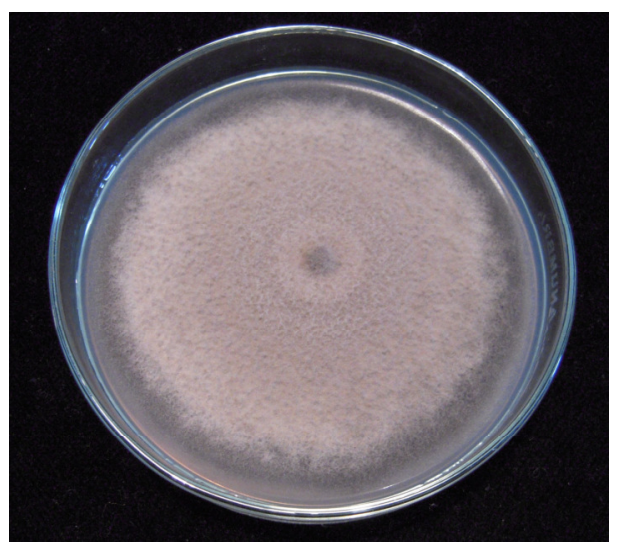

9. ábra: C. hawaiiensis telep. PDA táptalajon, 10 napig, sötétben történő inkubációt követően

\subsection{Tömlösgombák mikotoxinjai}

A mikotoxinok a tömlősgombák másodlagos anyagcseretermékei, amelyek bizonyos stresszhatások hatására termelődnek, pl. oxigénhiány, hirtelen hőmérséklet- és/vagy nedvességtartalom-változás esetén. Megkülönböztethetünk szántóföldi és raktári fonalasgombákat (Jouany 2007), de ezek jelenléte az élelmiszerekben, takarmányokban még nem jelenti automatikusan a mikotoxinok előfordulását is. Ugyanaz a gombafaj képes lehet többféle mikotoxin egyidejü szintetizálására, ugyanakkor egy adott mikotoxint több gombafaj is képes termelni (Sohár 2007).

Mai ismereteink alapján mintegy 15-20 mikotoxin jelent kiemelt humán- és állategészségügyi kockázatot. Sok mikotoxinogén gomba ubikviter, a környezetben mindenhol előfordul. Az élelmiszerek természetes mikrobiotájának és romlást okozó fonalasgomba populációjának leggyakoribb nemzetségei az Aspergillus, a Penicillium és a Fusarium (1. táblázat, Deák és mtsai. 2006). 
1. táblázat: Fontosabb mikotoxinok és termelőik (Deák és mtsai. 2006).

\begin{tabular}{|c|c|}
\hline Mikotoxin & Fonalasgomba fajok \\
\hline Aflatoxin & A. flavus, A. parasiticus \\
\hline Citrinin & A. terreus, $P$. citrinum, $P$. verrucosum, $P$. hirsutum \\
\hline Ciklopiezonsav & A. versicolor \\
\hline Deoxinivalenol & $F$. moniliforme, $F$. culmorum, $F$. avenaceum, $F$. nivale, $F$. roseum \\
\hline Diacetoxiscirpenol & F. moniliforme, $F$. equiseti \\
\hline Fumonizin & $F$. moniliforme ${ }_{2} F$. culmorum, $F$. avenaceum, $F$. nivale \\
\hline HT-2 toxin & F. moniliforme, $F$. culmorum, $F$. avenaceum, $F$. nivale \\
\hline Nivalenol & F. moniliforme, $F$. oxisporum, $F$. culmorum, $F$. avenaceum, $F$. nivale \\
\hline Ochratoxin & A. ochraceus, $P$. viridicatum \\
\hline Patulin & A. clavatus, $P$. expansum, $P$. roqueforti, $P$. griseofulvum \\
\hline Penicillinsav & A. ochraceus \\
\hline Satratoxin & Stachybotrys chartarum, Trichoderma viride \\
\hline Sterigmatocisztin & A. flavus, A. nidulans, A. versicolor, $P$. rugulosum \\
\hline $\mathrm{T}-2$ toxin & $F$. moniliforme, $F$. culmorum, $F$. avenaceum, $F$. nivale, $F$. roseum \\
\hline Trichodermin & Trichoderma viride \\
\hline Trichotecin & Trichothecium roseum \\
\hline Zearalenon (F-2) & $\begin{array}{l}F \text {. graminearum, } F \text {. moniliforme, } F \text {. culmorum, } F \text {. avenaceum, } F \text {. } \\
\text { nivale }\end{array}$ \\
\hline
\end{tabular}

\subsubsection{A mikotoxinok keletkezése}

A fonalasgombák, mint általában a mikroorganizmusok a kedvezőtlen környezeti tényezőkhöz (ún. stresszhatásokhoz) genetikai és biokémiai válaszreakciókkal alkalmazkodnak. A mikroorganizmusokat érő stresszhatások lehetnek halálosak (pl. vegyszerek, hőkezelés) vagy szaporodást gátló tényezők (pl. optimálistól eltérő pH, hiányos tápanyag ellátottság).

A mikotoxinok bioszintézise genetikailag meghatározott, szorosan kapcsolódik olyan elsődleges anyagcsere folyamatokhoz, mint az aminosavak és a zsírsavak metabolizmusa. A fonalasgombák aktuális toxintermelését a környezeti tényezők befolyásolják, így pl. a szubsztrát összetétele és minősége, a hőmérséklet és a páratartalom. A mikotoxinok takarmányokban való előfordulása földrajzi mintát mutat: az Aspergillus fajok optimális feltételeket a trópusi, szubtrópusi régiókban találnak, míg a Fusarium és Penicillium fajok a mérsékelt klímához adaptálódnak (Omar 2013). 
A hirtelen bekövetkező környezeti változásokat a sejtek akkor is stresszhatásként érzékelik, ha azok nem lépik túl a növekedésükhöz, szaporodásukhoz szükséges minimum és maximum értékeket. A stressz kivédése csak bizonyos határok között lehetséges, azon túl a sejtek már sérülnek, elpusztulnak. Ha a kedvezőtlen körülmények megszűnnek, akkor a sejtek olykor képesek helyreállítani sérüléseiket. A telepben előfordulhatnak olyan sejtek, amelyek életben vannak, de képtelenek a szaporodásra. A vegetatív sejtek jellemző stresszreakciója az, hogy megszünik az aktív szaporodásuk, továbbá lehetségesek egyéb válaszreakciók is, amelyek növelik a sejt ellenállását (Deák és mtsai. 2006).

A reaktív oxigén származékok (ROS) kémiailag reaktív molekulák, amelyek oxigént tartalmaznak. Erős reaktivitásuk a jelen lévő páratlan elektronnak köszönhető. Normál körülmények között a reaktív oxigén származékok eltávolításra kerülnek a sejtből különböző enzimek (szuperoxid-dizmutáz, kataláz vagy glutation peroxidáz) segítségével. A mikotoxinok toxicitásának fő oka a reaktív oxigén származékok termelődése, ami sejtkárosodáshoz vezet. Ennek során elváltozások történnek mind a membránlipideket alkotó többszörösen telítetlen zsírsavak, fehérjék és enzimek, mind pedig a DNS szerkezetében (Omar 2013).

Oxidatív stressz akkor fordul elő a sejtekben, ha a reaktív oxigén származékok, mint például a hidroxil gyök (HO·), a perhidroxil gyök (HOO·- ${ }^{-}$, a szuperoxid anion $(\cdot \mathrm{O} 2-)$, illetve egyéb reaktív oxigén származékok (beleértve a nitrogén oxidot is) termelődése meghaladja a sejt antioxidáns kapacitását. Az oxidatív stressz DNS károsodást, megnövekedő lipid peroxidációt, fehérje károsodást és a sejt pusztulását okozhatja (da Silva és mtsai. 2018).

Az utóbbi néhány évben több kutatás mutatott rá arra a jelenségre, hogy a fonalasgombák egy részének toxinjait a gazdanövény kémiailag megváltoztathatja: extrahálható konjugátumot képez belölük vagy extrahálás nélkül extrahálhatatlanul megköti őket. Extrahálhatatlanná válnak a mikotoxinok akkor, ha például sejtfalkomponensekként rögzülnek vagy más biopolimerekhez kötődnek. A növényben oldott formában „elraktározott” metabolitokat „maszkolt”, a nem oldott formában lévő, kötött mikotoxinokat „rejtett” toxinoknak nevezik. A maszkolt mikotoxinok az emésztéssel járó hidrolízissel visszaalakulhatnak az eredeti mikotoxin molekulákká. A maszkolt és a rejtett mikotoxinokat a szokásos mikotoxin-analitikai vizsgálatok nem mutatják ki, eltérő extrahálhatóságuk, megváltozott fiziko-kémiai tulajdonságaik és az eredeti molekulától eltérő immunológiai viselkedésük miatt (Farkas és mtsai. 2014). 


\subsubsection{A mikotoxinok és az élelmiszerbiztonság. Az élelmiszerek toxinszennyezetsége}

Magyarországon

A fonalasgombák jelenlétében a mikotoxinok keletkezésénekképződésének lehetősége az élelmiszerlánc teljes folyamatában fennáll; számolni kell megjelenésükkel már a termőföldön is, de a szállítás, raktározás, élelmiszeripari feldolgozás, forgalmazás teljes folyamatában elöfordulhatnak (Sohár 2007).

A mikotoxinszennyezésnek leginkább kitett terményekben (gabonafélék, gyümölcsök, diófélék, kávé, gyapot, földimogyoró, szója) a szennyezés általában nem egyenletesen oszlik el, hanem fertőzött gócok formájában jelenik meg. Ez utóbbi jelenség föleg az aflatoxin esetében jellemző, a fumonizin és a DON eloszlása egyenletesebbnek mutatkozik. Ebböl adódóan a hibák kiküszöbölése érdekében a szennyezettség meghatározásánál fontos a helyes mintaelőkészítés és feldolgozás. Az elemi mintákban a mikotoxin-koncentráció lényegesen magasabb lehet, mint a tétel átlagos szennyezettsége. A mikotoxin vizsgálatoknál a megbízható eredmények alapja a nagyszámú elemi mintából álló egyesített minta, amely tömegének redukálása csak több lépésben valósítható meg, figyelve arra, hogy a különböző méretü részecskék (különösen a darálás után) ne különüljenek el egymástól (Ambrus 2007).

Az élelmiszerek toxinszennyezettsége kapcsán Magyarország két kérdéskörben érintett: az egyik a hazai előállítású termékekben előforduló, a másik pedig a trópusi, szubtrópusi területekről importált élelmiszerek mikotoxinjainak problémája. Szintén problémát jelenthet az import útján Magyarországra kerülő toxinszennyezett élelmiszerek és a hazai termékek összekeverése (pl. 2004-es paprika botrány). Fontos tisztában lenni azzal, hogy a trópusi eredetü alapanyagokkal, késztermékekkel milyen mikroflóra, toxin érkezik, hogy megakadályozhassuk az élelmiszereink szennyezését.

Hazánkban 1970 óta vizsgálják az élelmiszerekben előforduló kémiai maradékanyagok előfordulását, beleértve a mikotoxinokat is. Laboratóriumi körülmények között az alábbi toxinok kimutatása és meghatározása történik: aflatoxinok (AFB1, AFB2, AFG1, AFG2, AFM1, AFM2), OTA, fuzárium F-2 toxin, T-2 toxin, DON, patulin és zearalenon. (Ácsné és Búza 2007).

Az Európai Bizottság a hazánkra is érvényes 1881/2006/EK rendeletben, illetve annak módosításaiban (165/2010/EU, 1058/2010/EU) szabályozza az élelmiszerekben előforduló szennyezőanyagok, köztük a toxinok felső határértékeit (Szeitzné és Frecskáné 2013).

A rendelet határértékeket ír elő az egyes termékcsoportok aflatoxin, OTA, patulin, valamint DON, zearalenon, fumonizin, T-2 és HT-2 tartalmára vonatkozóan. Az 
élelmiszerekben leggyakrabban észlelt mikotoxin az aflatoxin, ugyanis a szabályozásnak megfelelően az EU külső határain kötelező az ezekre vonatkozó vizsgálat elvégzése. Az ochratoxinnal történő fertőzéses esetek észlelése a belső piacokon vett mintákban számottevő (Szabó és Szeitzné 2007).

Tóth és munkatársai (2012) Magyarországon termesztett kukoricán vizsgálták a toxintermelő Aspergillus, Fusarium és Penicillium fajok előfordulását a 2010-es és 2011-es években. 2010-ben a nyár csapadékos, 2011-ben pedig forró és száraz volt. 2010-ben a vizsgált minták 81,94\%-a volt mikroszkópikus gombák által szennyezve, míg 2011-ben csak a minták 14,33\%-a. A nedves és csapadékos időjárásnak tulajdonítható, hogy a 2010-es évből származtak a legszennyezettebb minták. A 2011-es évjáratból származó mintáknál a száraz, forró időjárási körülmények miatt az Aspergillus-okkal való fertőzöttségük nagyobb volt, mint az előző évben. A vizsgálatok során megállapították, hogy az aflatoxinok, fumonizinek és az ochratoxinok szintje a vizsgált esetek jelentős részében az EU által meghatározott határérték felett volt. A munka rávilágított arra, hogy a klímaváltozás, a globális felmelegedés következményeként, a jövőben, hazánkban is számolni kell a mikotoxintermelö fonalasgomba fajok (pl. A. flavus) megjelenésével, fokozott jelenlétével. Az Európai Élelmiszerbiztonsági Hivatal (EFSA) modellszámításai szerint az átlaghőmérséklet $+2{ }^{\circ} \mathrm{C}-\mathrm{kal}$ történő növekedése a dél-európai régióban nagymértékben, Magyarországon pedig mérsékelten növeli majd a kukorica aflatoxin szennyeződésének kockázatát (Szeitzné és Frecskáné 2013).

\subsubsection{Illóolajok hatása a fonalas gombák mikotoxin termelésére}

A növényekböl nyert illóolajok ígéretes csoportját képezik azon természetes komponenseknek, melyek a fonalasgombák és termelt mikotoxinjaik ellen hatásosak lehetnek. A fonalas gombák mikotoxin termelésére hatással van a hőmérséklet és a nedvesség tartalom is (Velluti és mtsai. 2003, Hope és mtsai. 2005). Ami az illóolajok egyes komponenseinek mikotoxin szintézisre gyakrolt hatását illeti, több tanulmány nagymértékủ gátlásról számol be, melyet a fenolos komponenseknek (terpének, eugenol, karvakol, timol) tulajdonítanak. Feltételezik e komponensek enzimekre gyakorolt gátlását, ami a szulfhidril csoportokkal való reakciónak, illetve a fehérjékkel való kölcsönhatásnak tudható be (Dambolena 2008).

Az illólajok antifungális aktivitása nem mutat minden esetben korrelációt az egyes összetevők vonatkozásában (Ranasinghe és mtsai. 2002). A fonalasgombák növekedése és a toxintermelés nem mindig jár együtt (Téren és Novák 1990, Magan és mtsai. 2010a). 
A szegfüszeg illóolaj és annak fő komponense az eugenol, gyakran kerül alkalmazásra a mikotoxin termelő penészgombák vizsgálatakor. Rizs szemeken 2,4 mg/g eugenol olajat alkalmazva az $A$. flavus nem produkált növekedést, sőt, az AFB1 bioszintézis gátlást szenvedett (Reddy és mtsai. 2007). Sumalan és munkatársai (2013) kísérleteik során arra a következtetésre jutottak, hogy az általuk vizsgált, legjobb antifungális tulajdonságokkal rendelkező illóolajok ugyanakkor nem bizonyultak a leghatékonyabbnak a vizsgált Fusarium izolátumok mikotoxin termelése vonatkozásában. Az illóolajok antioxidáns tulajdonságai nem gyakoroltak döntő szerepet a mikotoxin ellenes hatásra.

Bullerman és munkatársai (1977) azt vizsgálták, hogy a szegfüszegolaj, a fahéjolaj, az eugenol és a fahéjaldehid milyen hatást gyakorolnak az $A$. parasiticus esetén annak növekedésére és AFB1 toxin termelésére. Eredményeik szerint, az illóolajok és komponenseik a MIC érték alatt alkalmazva, késleltették a fonalasgomba növekedését. A fahéjolaj antifugális hatását a fahéjaldehidnek tulajdonították. A fahéjaldehidet és az o-metoxifahéjaldehidet úgy írták le, mint az illóolaj azon komponensét, amely felelős az AFB1 szintézis gátlásáért.

Több szerző leírta, hogy az A. parasiticus esetében az ánizs, a fahéj, a zsálya, a menta, a kakukkfü és a rozmaring illóolaja képes gátolni a növekedést és visszaszorítani, elnyomni a mikotoxin termelést a MIC értékkel megegyező vagy annál alacsonyabb koncentrációkban (Soliman és Badeaa 2002, Rasooli és Owlia 2005, Razzaghi-Abyaneh és mtsai. 2008, Rasooli és mtsai. 2008).

Guzman-de-Pena és Ruiz-Herrera (1997) írta le az A. parasiticus esetén a spóraképződés és a mikotoxintermelés közötti összefüggést, amelynek oka a megosztott jelátviteli út lehet (Brodhagen és Keller 2006, Yu 2012). Az illóolajok terpénes és fenolos komponensei pro-oxidánsokként viselkedhetnek (Bakkali és mtsai. 2008).

Több, aflatoxin termelést vizsgáló tanulmányban leírták, hogy az illóolajok képesek növelni a gombák másodlagos metabolitjainak termelődését (da Cruz Cabral és mtsai. 2013). Dambolena és munkatársai (2010) $F$. culmorum és $F$. graminearum izolátumokkal végzett kísérleteinél, fahéj illóolaj hatására a növekedés szignifikáns gátlást szenvedett, de a toxin képződésnél növekedést detektáltak. Magan és munkatársai (2010b) arra a következtetésre jutottak, hogy a fungicidek szuboptimális szintje stimulálta gabonaszemeken a $F$. culmorum DON termelését. A fungicidek által okozott stressz, a vízhiánnyal együtt képes volt a mikotoxin termelés serkentésére (Aldred 2008). 
Prakash és munkatársai (2010) vizsgálták a szárított gyümölcsök, a füszerek és a diófélék mikroszkópikus gombák általi szennyezettséget, valamint a bors illóolajának antifungális hatását. Az A. flavus esetében az illóolaj alacsony koncentrációban $(0,1 \mu 1 / \mathrm{ml})$ történő alkalmazásakor több AFB1 termelödött, mint a kontrollok esetében. Nagyobb koncentrációban viszont a bors illóolaj gátolta az aflatoxin termelést, és $0,6 \mu 1 / \mathrm{ml}$ koncentrációnál már nem mutatkozott toxintermelés.

Jayashree és Subramanyam (2000) feltételezték, hogy az A. parasiticus aflatoxin termelése a fokozott oxidatív stressz következménye lehet, ami megnövekedett lipidperoxidációhoz és szabad gyökök képződéséhez vezet. A közelmúltban került publikálásra, hogy a linalool, ami a muskotályzsálya illóolaj egyik alkotóeleme, növeli a lipid-peroxidok koncentrációját, és koncentrációtól függően oxidatív stresszreakciót okoz a C. albicans-nál (Máté és mtsai. 2017). Fakoor és munkatársai (2012) iráni régióból származó római kömény illóolajával végeztek kísérleteket. Az A. flavus PICC AF24 és az A. parasiticus NRRL 2999 törzseket vonták be a tesztekbe. Kísérleteikben kimutatható volt az aflatoxin termelés mértéke és az alkalmazott illóolaj koncentrációja közötti összefüggés. Valamennyi törzs esetén a római kömény olaj alacsony koncentrációban történő alkalmazása azt eredményezte, hogy az aflatoxin szint megnövekedett. Az aflatoxin termelés csak az illóolaj nagy koncentrációban történő alkalmazása esetén szorult vissza.

Schmidt-Heydt és munkatársai (2008) szerint csak a mérsékelt abiotikus stresszfaktorok (pl. vízaktivitás, $\mathrm{pH}$ és hőmérséklet) vezetnek az A. parasiticus, F. culmorum és a Penicillium verrucosum mikotoxin bioszintézis génjeinek megemelkedett expressziójához; a mikotoxinok képződése a fonalasgombák részéről egy adaptációs reakciónak tulajdonítható.

\subsubsection{Az aflatoxinok jellemzése}

Az aflatoxinok a legtoxikusabb másodlagos metabolitok. Poliketid származékok, amelyeket számos fonalasgomba faj termel, de közülük az A. flavus, az A. parasiticus és az $A$. nomius a legjelentősebbek (Payne és Brown 1998).

Az aflatoxinokat először az 1960-as évek elején azonosították, amikor Angliában váratlanul több mint százezer pulyka súlyosan megbetegedett, majd elpusztult. Kimutatták, hogy a szárnyasoknál a mérgezést az A. flavus által termelt toxin okozta, ami a földimogyoró lisztet tartalmazó takarmányt szennyezte (Blount 1961). Az aflatoxinok a növénytermesztés, betakarítás, raktározás, élelmiszer előállítás bármely szakaszában megjelenhetnek. A toxin 
extrém veszélyes: hepatotoxikus, rákkeltő és immunszupresszív hatással bír (Williams és mtsai. 2004). Növeli a máj krónikus gyulladásos és daganatos megbetegedésének valószínűségét, az immunrendszer gyengítése miatt pedig a fertőzésekkel szembeni ellenálló képességet csökkenti (Szeitzné és Frecskáné 2013).

Legtöbbször az élelmiszer vagy takarmány elfogyasztásával jut a szervezetbe, de a legtoxikusabb AFB1 a bőrön keresztül is felszívódik (Boonen és mtsai. 2012). Májkárosodást, májrákot, gyermekeknél pedig fejlődési rendellenességet okoz (Khlangwiset és mtsai. 2011). $\mathrm{Az}$ aflatoxinok okozta megbetegedések komoly kockázatot jelentenek azokban az országokban, ahol az élelmiszerek és takarmányok nem ellenőrzöttek és nincs monitoring (Williams és mtsai. 2004).

Több mint 20 aflatoxin ismert, de ezek közül a négy legjelentősebb: aflatoxin B1 (AFB1), aflatoxin B2 (AFB2), aflatoxin G1 (AFG1) és aflatoxin G2 (AFG2) (Inan és mtsai. 2007). Az aflatoxinok kémiai szerkezetét a 10. ábra mutatja be.

Elnevezésük az ultraibolya fény hatására a toxinok által kibocsátott kék (Blue) és zöld (Green) színü fluoreszcencia alapján történt (Van Egmond 1989). A tejben előforduló aflatoxin M1 (AFM1) és az aflatoxin M2 (AFM2) az AFB1 és az AFB2 hidroxilált metabolitjainak tekinthetőek (Giray és mtsai. 2007). Az aflatoxinok száraz körülmények között meglehetősen ellenállóak, hő hatására csupán $240-300^{\circ} \mathrm{C}$ körül bomlanak (Darvas 2004).
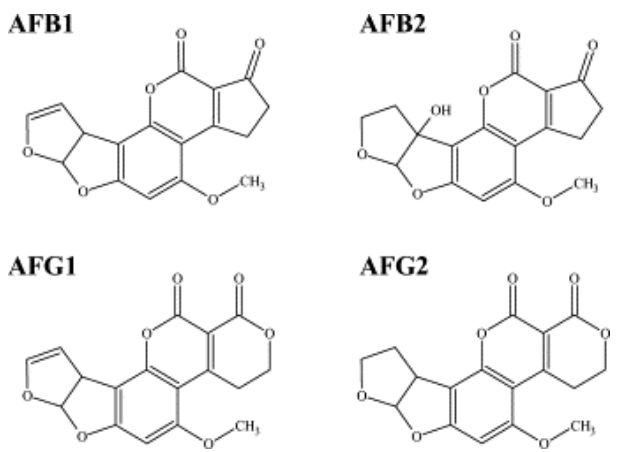

10. ábra: Az aflatoxinok kémiai szerkezete (Ventura és mtsai. 2004).

Arányaikat tekintve, a vizsgált mintákban az AFB1 koncentráció általában meghaladja az összes aflatoxin mennyiség felét, míg az AFB2 és az AFG2 fordul elő a legalacsonyabb koncentrációban. A B és $\mathrm{G}$ típusú aflatoxinok arányát nagymértékben befolyásolja a hőmérsékletváltozás, valamint a gombatörzsek aránya az adott mátrixban. Ez azt jelenti, hogy az AFB és az AFG koncentráció arányok régiófüggők (Schmidt-Heydt és mtsai. 2010). 
Matumba és munkatársai (2015) malajziai kukorica és földimogyoró mintákat vizsgáltak az aflatoxin-szennyezettség szempontjából. Az AFG1 arány a szennyezett mintáknál általában magasabb volt, mint az összes aflatoxin (B1, B2, G1, G2) fele. Ez az arány eltér az általában publikált arányoktól, bár nem definiálták, hogy mely fonalasgomba faj eredményezte.

\subsubsection{Aflatoxinok bioszintézise}

Az aflatoxinok poliketid típusú vegyületek (difurano-kumarin származékok), melyeket több aromás gyürű alkot. A bioszintézisükben mintegy 30 gén potenciálisan érintett.

Az aflatoxinok bioszintézisét mintegy 50 éve tanulmányozzák. Az aflatoxin bioszintézis génexpressziójának szabályozása több szinten történik, több szabályzó komponens által. Vannak genetikai faktorok, biotikus és abiotikus elemek, amelyek hatnak az aflatoxin bioszintézisére. Itt megemlítendő a szén, a nitrogén és az aminosavak jelentősége is. A vízaktivitás, a pH, a növényi fejlődés stádiuma, az oxidatív stressz, a növényi metabolitok jelenléte mind fontos szereppel bírnak az aflatoxin bioszintézisében. Kiemelt jelentőségűek az enzimek (pld. poliketid szintetáz, zsírsav szintetáz, reduktáz, oxidáz, észteráz), amelyek a toxin termelésének minden lépésében szerepet játszanak (Yu 2012, Yu és mtsai. 2004). Ehrlich és Yu (2009) szerint a folyamat 27 enzimatikus lépést tartalmaz.

Az A. flavus és az A. parasiticus esetén az aflatoxin képződésért felelős génklaszter 75 kb méretü. Az aflatoxin képződés kezdeti szubsztrátuma egy hexanoil starter egység. A poliketid szintézisben két zsírsav szintetáz és egy poliketid szintáz (NR-PKS, PksA) vesz részt (Yu 2012). Az aflatoxin képződés kezdeti szubsztrátuma egy hexanoil-csoport, amely 7 malonil-KoA-val egyesül norsolorinsavvá (NOR). A szintézis folyamatában ez az első, stabilnak tekinthető közti termék. A folyamat lépései a következőek: norzolorinsav $(\mathrm{NA}) \rightarrow$ averufin $(\mathrm{AVF}) \rightarrow$ verzikonál-acetát $(\mathrm{VAL}-\mathrm{A}) \rightarrow$ verzikolorin A (VA). A Verzikolorin A-ból végül furanofurán vázú szterigmatocisztin (ST) keletkezik. Ez utóbbi vegyületet az aflatoxin-bioszintézis utolsó előtti előanyagának tartják. A folyamat végén AFB1, AFB2 keletkezik (Dutton 1988, Darvas 2004, Yu és mtsai. 2004, Tsai és Ames 2009, Samuel és mtsai. 2013).

$\mathrm{Az}$ aflatoxinok bioszintéziséért felelős gének génklaszterben helyezkednek el (Yu és mtsai. 2004). Az aflR regulátorgén a génklaszter közepén található, közelében az aflS génnel (Chang 2004). Az aflR gén egy szekvencia-specifikus DNS-kötő kétmagvú cinkujj fehérjét kódol, ami a legtöbb aflatoxin bioszintézisben résztvevő struktúrgén transzkripciós 
aktivációjához szükséges (Woloshuk és mtsai. 1994). Chang (2003) szerint, az aflS gén szerepe az aflR DNS-hez történő kötődésének támogatása, ezáltal aktiválódik az aflatoxin struktúrgének transzkripciója.

$\mathrm{Az}$ aflR gént érintő veszteség nem állítja meg a spórázást vagy a szkleróciumok képződését, de hatással van a spórák számára (mennyiségére). (Calvo és mtsai. 2002).

Az aflatoxin termelés a fonalasgomba növekedésének stacioner fázisában következik be, amikor az elpusztult sejtek helyére új sejtek kerülnek. Ennek a folyamatnak a hosszát befolyásolja a tápanyag elérhetősége is. A sejtpusztulás alatt, a peroxidatív bomlás a membránban jelen lévő ergoszterol által is befolyásolt. (Passi és mtsai. 1994).

\subsubsection{Az aflatoxin előfordulása, a toxinképződés feltételei}

$\mathrm{Az}$ aflatoxinokat termelö fonalasgomba fajok széles körben elterjedtek, a toxin előfordulása mégis földrajzi és szezonális tényezők függvénye. Trópusi, szubtrópusi övezetben a toxinszennyezettség mindig nagyobb, mint mérsékelt éghajlat alatt, mivel a gombák szaporodásához és toxintermeléséhez $20-30^{\circ} \mathrm{C}$ közötti hömérsékletre és minimum 80-85\% közötti relatív páratartalomra van szükség (Kovács és Bíró 2003). Yu (2012) kísérletei szerint az aflatoxinok képződésének a $28-36^{\circ} \mathrm{C}$ közötti tartomány tekinthető optimálisnak. Ezen tartományon kívül eső hőmérséklet már gátolja az aflatoxin termelését.

Rao és munkatársai (1998) az A. parasiticus-on végzett kísérleteikkel igazolták, hogy az aflatoxinok bioszintézise a növekedés 36. órájában kezdődik el. Kimutatták a kalmodulin szerepét a másodlagos metabolitok képződésében, amely in vivo körülmények között befolyásolja az aflatoxinok szintézisét a protein foszforiláció szabályzásával. Hamid és Smith (1987) A. flavus-on végzett kísérletei során megállapította, hogy a növekedés a 2. és a 6. nap között mutatkozott a leggyorsabbnak. Az AFB1 és AFG1 termelődése a 4. és 6. napon volt a legjelentősebb, amit aztán folyamatos csökkenés követett az inkubáció 12. napjáig.

Darvas (2004) vizsgálatai rámutattak, hogy ugyanazon $A$. flavus törzs $20^{\circ} \mathrm{C}$ körül föként AFG1-et, míg $30^{\circ} \mathrm{C}$ körül AFB1-et termel.

Jayashree és Subramanyam (2000) az A. parasiticus esetében igazolták, hogy az oxidatív stressz elősegíti az aflatoxin képződését. A szénforrás tekintetében az egyszerü cukrok, mint a glükóz, a fruktóz, a maltóz elősegítik az aflatoxinok képződését (Liu és mtsai. 2016), míg a pepton, a szorbóz vagy a laktóz nem (Buchanan és Lewis 1984, Payne és Brown 1998). A nitrogénforrások közül a prolin, az aszparagin, a kazein, az ammónium-szulfát 
eredményez magasabb aflatoxin szintet (Payne és Hagler 1983), míg a nyomelemek közül a cink mutat stimuláló hatást (Wee és mtsai. 2016).

Wilkinson és munkatársai (2007) az A. flavus-on végzett kísérleteik során arra mutattak rá, hogy a különböző aminosavak különböző hatással bírnak az aflatoxin képződésre. Eredményeik alapján a triptofán gátolta az aflatoxin képződést, míg a tirozin fokozta azt.

Már több évtizeddel ezelőtti tudományos eredmények igazolták, hogy az aflatoxin termelésére gátló hatásuk van a rovarölő szereknek (Draughon és Ayres 1981), a növényi drogoknak (Hitokoto és mtsai. 1978), a füszereknek (Bullerman és mtsai. 1977), a trikarbonsav ciklus közti termékeinek (Shantha és Murthy 1981) és az élelmiszertartósítóknak (Uraih és Chipley 1976).

Ezzel párhuzamosan több munka bizonyítja azt is, hogy lehetséges a mikotoxin termelés stimulálása is (Uraih és Chipley 1976, Yousef és Marth 1981). Gareis és munkatársai (1984) leírták, hogy a szorbinsav jelenléte stimulatív hatással van mind az A. flavus AFB1 toxin, mind pedig a Fusarium acuminatum T-2 toxin termelésére. Ebben a vizsgálatban az aflatoxin mennyisége egészen az inkubáció 20. napjáig növekedést mutatott. Eredményeikből arra következtettek, hogy bizonyos mennyiségü szorbinsav (a minimális gátló koncentráció közelében) csökkenti a trikarbonsav ciklus aktivitását. Ez acetil-koenzim A felhalmozódásához vezethet, ami az AFB1 és a T-2 toxin bioszintézisében lényeges közbenső termék.

Fanelli és munkatársai (1983) az A. parasiticus aflatoxin bioszintézisének vizsgálata során megállapították, hogy a di- és hexahidro-cerulenin nem gátolták a zsírsav szintetázt, viszont a cerulenin és a tetrahidro-cerulenin igen, stimulálva ezzel az aflatoxinok képződését.

Kim és munkatársai (2008) szintén pozitív korrelációt írtak le az oxidatív stressz és az aflatoxin bioszintézis között. Szabadgyökök jelenlétében az adott organizmus védekező mechanizmusként aflatoxint termel. A lipid peroxidáció, az antioxidáns enzimek aktivizálása, a fehérje foszforiláció és defoszforiláció mind fokozza az aflatoxin termelést (Jayashree és Subramanyam 2000).

\subsubsection{Az aflatoxinok biológiai hatása, az aflatoxikózis}

A takarmányokban megjelenő mikotoxinok az állatok számára egészségkárosító hatásúak, de az állati termékekben (hús, tej, tojás) felhalmozódva a fogyasztó számára is veszélyforrást jelenthetnek (Nagy és mtsai. 2009). Az aflatoxinok által okozott mikotoxikózis neve aflatoxikózis (Darvas 2004). 
A kérődzők viszonylag ellenállóak az aflatoxikózissal szemben, de az aflatoxinok tejben való jelenléte az emberi egészségre nézve negatív hatású. A sertéseknél az aflatoxinokat tartalmazó takarmány fogyasztása közvetetten befolyásolja a reprodukciót, de számolni kell a takarmányfelvétel és a növekedés csökkenésével is. Az aflatoxikózis jeleként máj- és vesekárosodással, továbbá véralvadási problémákkal találkozhatunk. Az aflatoxinok a sejtes és a humorális immunválaszt gátolják, így csökkentve a baktériumokkal, gombákkal, vírusokkal és parazitákkal szembeni ellenálló képességet (Diekman és Green 1992).

Az aflatoxin rákkeltő hatása az indirekt mutagén hatásából következik. Az aflatoxinok detoxifikálásában a glutation-S-transzferáz és a citokróm P-450 enzimrendszerek vesznek részt. A fejlődő országokban az aflatoxikózis okozta májrák előfordulása akár tízszer gyakoribb, mint az iparilag fejlett országokban (Darvas 2004).

\subsubsection{Az aflatoxinra megállapított határértékek}

Az aflatoxinok jelenléte komoly gazdasági következménnyel bír. Potenciális egészségügyi veszélyük világossá teszi, hogy az élelmiszerekben és a takarmányokban minimalizálni kell az aflatoxin szennyezettséget (Yu 2012). A „surveillance” (felderítő) programok létrehozásának célja, hogy csökkentsék az aflatoxinok emberi és állati szervezetekbe kerülö kockázatát. Ezt a munkát segítik a nagyszámú minták gyors vizsgálatára létrehozott tesztek, analitikai módszerek (Nagy Teljesítményü Folyadékkromatográfia (HPLC), vékonyréteg kromatográfia, gázkromatográfia, radioimmuno mérés, enzim-kapcsolt immunszorbens módszer) (Wilson 1989).

1985-től kezdődően az USA Élelmiszerbiztonsági és Gyógyszerészeti Hivatala (USFDA) szabályozza a mikotoxinok megengedett mennyiségét az élelmiszerekben. A feldolgozási folyamatoknál a Jó Gyártási Gyakorlat (GMP) és a Veszélyelemzés és Kritikus Ellenőrzőpontok (HACCP) alkalmazása segítheti a jó minőségű és biztonságos végtermék előállítását (Kumar és mtsai. 2016).

Az EU tagországokban a 178/2002/EK rendelet elöírásainak megfelelően, az Európai Unió Élelmiszer- és takarmánybiztonsági Riasztási Rendszere) (RASFF) müködik. A tagállamoknak haladéktalanul jelenteniük kell a Bizottságnak, amennyiben a sürgősségi riasztórendszeren keresztül észlelik, hogy élelmiszerekből és takarmányokból származó közvetlen vagy közvetett veszély fenyegeti az emberi egészséget (Baiguini és mtsai. 2011). Hazánkban az EU gyorsvészjelző hálózatában a Nemzeti Élelmiszerlánc-biztonsági Hivatal (NÉBIH) a kapcsolattartó. 
Élelmiszerbiztonsági szempontból a mikotoxin kérdés összetett problémát jelent az egész világon, amelynek megoldása csak integrált intézkedésekkel, összehangolt megelőzéssel lehetséges. Világviszonylatban 50 ország saját jogalkotásában rendelkezett a megengedett toxinszennyezettség maximális mértékéről (Aswani Kumar és mtsai. 2016). Azonban egyes országokban (pl. Etiópia) a növekvő veszély ellenére a mai napig sincs szabályozás az élelmiszerek és a takarmányok mikotoxin-szennyezettségére vonatkozóan (Wolde 2016).

\subsubsection{Gabonák toxinszennyezettsége}

A potenciális toxintermelő fonalasgombák a szántóföldön és a raktárakban egyaránt jelen lehetnek. A mezőgazdasági termelés folyamán főként a Fusarium, Alternaria, Aspergillus, Penicillium nemzetségbe tartozó fonalasgomba fajok jelenlétével kell számolni (Mézes 2006).

A gabonatermesztés a maga 15 millió tonna éves termelésével a legfontosabb élelmiszer- és takarmány alapanyagokat szolgáltatja. Hazánkban a különböző gabonafélék a termőterületek mintegy kétharmadát foglalják el (Mesterházy 2007). A teljes kiőrlésű lisztből készült sütőipari termékek, müzlik, reggeli cereáliák, kukoricatermékek nagy mennyiségben tartalmaznak biológiailag értékes anyagokat (rostokat, vitaminokat, ásványi anyagokat). Azonban, ha a gabonamagvak fonalasgombával fertőződtek, akkor a mikotoxin koncentráció is nagyobb lehet bennük, mint a hagyományos termékekben (Kovács és Bíró 2003). Az éghajlati adottságoknak köszönhetően Magyarországon a legnagyobb problémát a Fusarium fajok okozzák. Elsődlegesen a gabonafélék (búza, kukorica) érintettek, amelyek az ország vetésterületének jelentős hányadát foglalják el (Kovács és Bíró 2003).

A klímaváltozás, a globális felmelegedés hatására az elmúlt években a magyar termőterületeken, valamint több Európai országban is megjelentek az aflatoxint termelő Aspergillus fajok. Sebök és munkatársai (2016) Magyarország hét régiójából a 2013-as és 2014-es években a talajból és kukoricáról izoláltak A. flavus és A. parasiticus törzseket. 2012ben Baranyi és munkatársai (2014) olyan kukorica mintákat vizsgáltak, amelyeket hazánkban és Szerbiában gyüjtöttek. A betakarítás után gyüjtött mintákban föként a Fusarium fajok, míg a raktározott mintákban föként az Aspergillus-ok domináltak. Az A. flavus 76\%-a a raktári mintákban és 33\%-ban a frissen betakarított anyagban fordult elö. 
A vizsgált fonalasgombák természetes szubsztrátjaként a búzát (Triticum aestivum) választottuk. Ezt a gabonát a legszélsőségesebb éghajlati viszonyok kivételével (trópusok, sivatagok, sarkvidékek) szinte mindenhol termesztik a világon. Takarmányként történő hasznosítása mellett élelmiszeripari feldolgozása leginkább őrlemények formájában történik, főként kenyeret készítenek belőle (Gyimes és Véha 2004).

A búzaszem alakja aszimmetrikus, hosszúkás, a csíra felöli résznél kerekebb és szélesebb, mint a hegyesebbik vége, ez utóbbin apró szőröcskék, ún. szakál található. A csírával szemközti oldal közepén hasi barázda húzódik végig (Dexter és Wood 1996), melyben megtapadnak a mikroorganizmusok és a porszennyeződések. A szem általában 5-9 mm hosszú, súlya 35-50 mg között változik. A búzaszem szerkezetileg három fő részből áll: héjból (13-17\%), csírából (2-3\%) és keményítő tartalmú magbelsőből (80-85\%) (Šramková és mtsai. 2009).

A búzakorpa (külső héjrészek) jelentős mennyiségben tartalmaz rostokat, mely számos betegség megelőzésében szerepet játszhat (Stevenson és mtsai. 2012). A héjfrakció gazdag ásványi anyagokban, B6 vitaminban, tiaminban, folsavban, E vitaminban és antioxidánsokban (Shewry 2009). Ugyanakkor, mind az emberi fogyasztásra, mind a takarmányozási célra szánt gabonaipari termékek esetén a korpa jelenléte magában hordozza az aflatoxin szennyeződés lehetőségét, amennyiben a búzaszemet fonalasgombák fertőzték (Terzić és mtsai. 2012). 


\section{CÉLKITÜZÉSEK}

A fonalasgombák és az általuk termelt mikotoxinok globálisan egyre nagyobb problémát jelentenek. Elengedhetetlen a gyors, könnyen alkalmazható stratégiák kidolgozása, melyek egyfelől a fonalasgombák szaporodását, másrészt toxintermelésük gátlását célozzák meg.

$\mathrm{Az}$ élelmiszerbiztonság mellett a fogyasztók részéről egyre inkább preferált a környezetbarát technológiák, a természetes összetevők alkalmazása, amelyek az egészségre nézve nem jelentenek kockázatot.

Munkánk fö célja az volt, hogy megvizsgáljuk néhány jól ismert és gyakran alkalmazott illóolaj több Aspergillus és Fusarium faj növekedésére gyakorolt hatását. Kísérleteket végeztünk Aspergillus fajok aflatoxin termelésének visszaszorítására, amelyek során illóolajat tartalmazó gőztérben inkubáltuk a telepeket.

Kísérleteink kezdetén a következő fő célokat fogalmaztuk meg:

1. Illóolajok fonalasgomba fajok növekedésére gyakorolt hatásának vizsgálata: telepnövekedés gátlása, antifungális hatás.

2. Illóolajok okozta morfológiai változások detektálása mikroszkópos- és vizuális vizsgálatokkal.

3. Illóolajok hatásának vizsgálata az $A$. parasiticus és az A. nomius aflatoxin termelésére szilárd és folyékony tápközegben.

4. Illóolajok hatásának vizsgálata búza szubsztráton inkubált $A$. parasiticus toxintermelésére vonatkozóan. 


\section{ANYAGOK ÉS MÓDSZEREK}

\subsection{Alkalmazott tápközegek}

Az Aspergillus izolátumokat malátás, szilárd táptalajon (MEA), a Cochilobolus és Fusarium izolátumokat PDA táptalajon tartottuk fenn. A törzsek átoltását 4 havonta hajtottuk végre és $4^{\circ} \mathrm{C}$-on tároltuk. A Petri-csészékben végzett kísérleteknél szilárd táptalajokon történt a tenyésztés, az Erlenmeyer lombikokban végzett kísérletekhez malátás táplevest készítettünk. Szilárd malátás táptalaj (MEA): 0,5\% maláta kivonat, 0,5\% élesztő (VWR), 0,5\% glükóz (VWR), 2\% agar (VWR)

Szilárd PDA táptalaj: 3,9\% Potato Dextrose por (VWR), 1\% agar (VWR)

Malátás tápleves: 3\% Bacto malt extract por (VWR), 1\% élesztő (VWR), 1\% glükóz (VWR)

\subsection{Alkalmazott mikroorganizmusok}

A kísérletek során vizsgált fonalasgomba törzseket a 2. számú táblázat mutatja be. A tiszta tenyészeteket PDA, illetve MEA ferde agarokon tartottuk fenn, $4^{\circ} \mathrm{C}$-on. Valamennyi izolátum a Szeged Mikrobiológiai Törzsgyüjteményből (SZMC, SZTE TTIK Mikrobiológiai Tanszék, Szeged, Magyarország) származott.

2. táblázat: A kísérletek során tesztelt mikroorganizmusok.

\begin{tabular}{|c|c|c|c|}
\hline $\begin{array}{c}\text { Törzsgyüjteményes } \\
\text { kód } \\
\text { (SZMC) }\end{array}$ & Fajnév & $\begin{array}{c}\text { További } \\
\text { azonosító kód }\end{array}$ & $\begin{array}{c}\text { Eredet, } \\
\text { származási hely }\end{array}$ \\
\hline SZMC 13046B & C. hawaiiensis & BRIP 28916/b & -/- \\
\hline SZMC 11031 & F. graminearum & NRRL 28436; 2 & $\begin{array}{c}\text { narancs ág /Új } \\
\text { Caledónia }\end{array}$ \\
\hline SZMC 11040 & F. culmorum & NRRL 29379 & -/ USA \\
\hline SZMC 22273 & A. nomius & NS 640 B/22 & kukorica/Szerbia \\
\hline SZMC 2069 & A. westerdijkiae & $\begin{array}{c}\text { NRRL 3174, } \\
\text { típus törzs }\end{array}$ & cirok/ Dél-Afrika \\
\hline SZMC 2049A1 & A. longivesica & NRRL 5215 & $\begin{array}{c}\text { esöerdö talaja/ } \\
\text { Nigéria }\end{array}$ \\
\hline SZMC 2473 & A. parasiticus var. globosus & CBS 260.67 & -/Japan \\
\hline SZMC 2025 & A. albertensis & $7 / 3$ & -/- \\
\hline SZMC 11487 & F. verticillioides & $1264 / 10$ & $\begin{array}{c}\text { keratomikózis / } \\
\text { India }\end{array}$ \\
\hline SZMC 3221 & A. awamori & Sulthan 7 & $\begin{array}{c}\text { Mazsola / } \\
\text { (kereskedelem) } \\
\text { Magyarország }\end{array}$ \\
\hline
\end{tabular}




\subsection{Alkalmazott illóolajok}

A kísérlet során alkalmazott illóolajokat (borókaolaj, citromolaj, fahéjolaj, majoránnaolaj és muskotályzsálya olaj) az Aromax Kft-től szereztük be. Az összetevőket a gyártó laboratóriumában határozták meg, gázkromatográfia-tömegspektrometria GC-MS eljárással (Agilent; GC: 6850 Series II; MS: 5975C VL MSD), Agilent 19091S-433E oszlop használatával. Az egyes illóolajat adó növényi részeket a 3. táblázat mutatja be a gyártó által megadott információk alapján.

3. táblázat: A kísérletek során felhasznált illóolajok eredete

\begin{tabular}{ll}
\hline Növény neve & Illóolajat adó növényi rész \\
\hline Boróka & tobozbogyó \\
Citrom & gyümölcshéj \\
Fahéj & fahéjfa belső kérge \\
Majoránna & hajtás \\
Muskotályzsálya & hajtás \\
\hline
\end{tabular}

\subsection{Alkalmazott természetes szubsztrát (búza)}

A szenzitív, gombás fertőzésekre fogékony fajtájú búzát (kód: GK 17.13.) a Gabonakutató Nonprofit Kft. (Szeged, Magyarország) bocsátotta rendelkezésünkre.

\subsection{Antifungális hatás vizsgálata}

\subsubsection{Illóolajok hatása a fonalasgombák növekedési paramétereire}

A kísérletek során az ún. fordított Petri-csésze technikával dolgoztunk, a fonalasgomba telepek növekedését illóolaj tartalmú gőztérben valósítottuk meg (Mazidah és mtsai. 2012, Krisch és mtsai. 2013).

A tesztekbe bevont, 10 fonalasgomba izolátum tiszta tenyészeteiből kivett fonalasgomba inokulumokat átoltottuk Petri-csészékben lévő PDA, illetve malátás táptalajra. A tenyészeteket $25^{\circ} \mathrm{C}$-on, 72 órán át inkubáltuk. Ezt követően a telepek széléből (ahol a legfiatalabb fonalak találhatók) 3 mm-es steril dugófúróval kiemeltünk egy korongot, melyet fejjel lefelé egy másik, 25 ml szilárd táptalajt tartalmazó Petri-csészébe helyeztünk. 
A Petri-csésze fedelébe egy csepp agar (2\%) segítségével $10 \mathrm{~mm}$ átmérőjü, steril szürőpapír-korongot ragasztottunk, amire pipetta segítségével olyan mennyiségü illóolajat vittünk fel, amely a csészék légterében $0,42 \mathrm{mg} / \mathrm{cm}^{3}, 0,21 \mathrm{mg} / \mathrm{cm}^{3}, 0,105 \mathrm{mg} / \mathrm{cm}^{3}$, illetve $0,052 \mathrm{mg} / \mathrm{cm}^{3}$ illóolaj koncentrációt eredményezett. A gőzteres kísérletekben az aktuális illóolaj koncentráció nehezen állapítható meg, mivel az egyes komponensek illékonyságuk sorrendjében szabadulnak fel a papír korongról. A légtérből a komponensek a táptalajba illetve a gomba felületére abszorbeálódnak, majd onnan deszorbeálódnak míg egyensúlyi állapot nem alakul ki. A legtöbb légtérben végzett kísérletnél úgy tekintik, hogy az illóolaj teljes egészében a légtérbe kerül, és az illóolaj koncentrációt a légtérfogatra számítva adják meg (Mazidah és mtsai. 2012). A kísérletekhez azonos méretü, azonos légtérfogatú csészéket használtunk.

A kontroll Petri-csészékben a korongra illóolaj helyett, $7 \mu$ l steril desztillált vizet cseppentettünk. A Petri-csészéket fordított helyzetben parafilmmel lezártuk. Ezt követően a telepeket $25^{\circ} \mathrm{C}$-on, 10 napon keresztül inkubáltuk. A telepek átmérőjét vonalzó segítségével naponta lemértük. A méréseket három párhuzamos sorozatban végeztük.

Mivel a fonalasgomba tenyészetek leggyakrabban a felületeken alakulnak ki, növekedésük sugárirányban terjed, a szaporodás legegyszerübb vizsgálati módszere a telepátmérő mérése. Ekkor feltételezzük, hogy a sejttömeg arányos a hifahosszal és a kialakuló telepet lényegében kétdimenziósnak tekintjük. Fiatal telepeknél a telepátmérő növekedési sebessége alkalmas a szaporodás jellemzésére (Deák és mtsai. 2006).

A mérési eredményekből kiszámítottuk a telepek antifungális indexét (\%) és a telepnövekedés sebességét (mm/nap). A telepnövekedési sebesség a telepek növekedési görbéinek lineáris szakaszára mért egyenes meredekségeként definiálható (Passone és mtsai. 2012). Az antifungális indexet a következő képlettel számítottuk ki (Shukla és mtsai. 2012): Antifungális index $(\%)=\left(1-\left(\mathrm{D}_{\mathrm{t}} / \mathrm{D}_{\mathrm{c}}\right)\right) \times 100$ $\mathrm{D}_{\mathrm{t}}$ : az illóolajjal kezelt telepek átmérője $(\mathrm{mm}), \mathrm{D}_{\mathrm{c}}$ : kontroll telep átmérője $(\mathrm{mm})$

\subsubsection{A minimális gátló koncentráció (MIC) meghatározása}

A kísérletekben a MIC értékek az ún. „agar hígításos” (Balouiri és mtsai. 2016), valamint a fordított Petri-csésze módszerrel $\left(0,42 \mathrm{mg} / \mathrm{cm}^{3}, 0,21 \mathrm{mg} / \mathrm{cm}^{3}, 0,105 \mathrm{mg} / \mathrm{cm}^{3}\right.$ illetve $0,052 \mathrm{mg} / \mathrm{cm}^{3}$ illóolaj a légtérben koncentráció mellett) is meghatározásra kerültek. 
Az agar-hígításos módszernél, a kísérletek tárgyát képezö, tíz fonalasgomba izolátum átoltása után a telepeket 7 napig inkubáltuk $25^{\circ} \mathrm{C}$-on MEA, illetve PDA táptalajon. A hétnapos telepekből $8 \mathrm{~mm}$ átmérőjű micélium korongokat vágtunk ki dugófúró segítségével, majd a tápközeget tartalmazó Petri csészébe helyeztük azokat. Az illóolajok hatékonyabb oldódása érdekében a tápközeghez 0,1\% Tween-80-t is adtunk. Az illóolajat a még folyékony halmazállapotú, $15 \mathrm{ml}$ térfogatú tápközegbe kevertük úgy, hogy felező hígítási sort készítettünk 9 lépésben, 0,15-40 $\mathrm{mg} / \mathrm{cm}^{3}$ tartományban. A Petri-csészéket parafilmmel lezártuk és $25^{\circ} \mathrm{C}$-on 10 napig inkubáltuk. A kontroll csészék tápközegei nem tartalmaztak illóolajat.

Mindkét módszernél 10 nap inkubációt követően meghatároztuk a MIC értékeket, azaz azt a legkisebb illóolaj koncentrációt $\left(\mathrm{mg} / \mathrm{cm}^{3}\right)$, ahol nem volt látható telepnövekedés (Burt 2004).

\subsection{Illóolajok hatása az Aspergillus-ok aflatoxin termelésére}

\subsubsection{Szilárd táptalajon nevelt tenyészetek aflatoxin termelésének detektálása}

A növekedési kísérleteknél leírt, fordított Petri-csésze technikával dolgoztunk. A telepek növekedése 10 napon keresztül, $25^{\circ} \mathrm{C}$-on, illóolaj gőztérben történt. A gőztér 0,42 ; 0,$21 ; 0,105$ és $0,052 \mathrm{mg} / \mathrm{cm}^{3}$ koncentrációban tartalmazta az illóolajokat.

A minták aflatoxin tartalmának meghatározásához Baranyi és munkatársai (2015) módszerét alkalmaztuk. A fonalasgomba telepeket tartalmazó szilárd tápközeget felaprítottuk és Falcon csőbe helyeztük át. Ehhez 10 ml diklór-metánt (VWR) adtunk hozzá, és a csöveket 2 ×20 percen keresztül erőteljesen rázattuk. A folyékony fázist egy másik csőbe vittük át, majd az extrakciót megismételtük (10 ml diklór-metán hozzáadásával, 2x20 percen keresztül történő rázatással). $\mathrm{Az}$ extraktumokat egyesítettük, majd centrifugáltuk $3000 \mathrm{rpm}$ fordulatszámon, $25^{\circ} \mathrm{C}$-on, 30 percen keresztül. A szerves fázist nitrogénáram mellett bepároltuk. A mintákat $10 \mathrm{ml}$ metanolban oldottuk vissza. Ebböl az oldatból $2 \mathrm{ml}-\mathrm{t}$ vittünk Eppendorf csövekbe, majd ezt újra bepároltuk $45^{\circ} \mathrm{C}$-on. A maradékot veszélyes hulladékként kezeltük.

A minták aflatoxin tartalmát a telepterületre vonatkoztattuk $\left(\mu \mathrm{g} / \mathrm{mm}^{2}\right)$, melyhez a telepátméröket a növekedési paraméterek vizsgálata során naponta rögzítettük. 


\subsubsection{Illóolajok hatása tápoldatos fermentáció során - az aflatoxin termelés kinetikájának vizsgálata}

A kísérleteket az $A$. parasiticus és $A$. nomius izolátumokkal végeztük el. Petri-csészében, malátás agaron, 7 napos tenyészetet hoztunk létre, amelyből $1 \times 10^{6}$ konídiumszámú szuszpenziót készítettünk. $20 \mathrm{ml}$ térfogatú sterilizált Erlenmeyer lombikokba 9,5 ml malátás

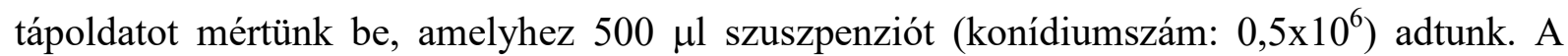
lombikokban a következő légtérfogatra vonatkoztatott koncentrációt hoztuk létre: 0,42 $\mathrm{mg} / \mathrm{cm}^{3}, 0,21 \mathrm{mg} / \mathrm{cm}^{3}, 0,105 \mathrm{mg} / \mathrm{cm}^{3}$, illetve $0,052 \mathrm{mg} / \mathrm{cm}^{3}$. Ehhez a kísérlethez használt lombikok térfogatát egyenként lemértük, a tápoldat és a szuszpenzió térfogatát ismerve, lombikonként meghatároztuk azt az illóolaj mennyiséget, mely az adott koncentráció eléréséhez szükségesnek bizonyult. Az illóolajokat pipetta segítségével vittük fel, a lombikok fedésére szánt, alufóliára felvarrt papírkorongokra. A lombikokat alufóliával, illetve celofánnal légmentesen lezártuk. A mintákat 15 napig $25^{\circ} \mathrm{C}$-on inkubáltuk. Háromnaponta 3-3 párhuzamos mintát extraháltunk ki. Minden extrakciót külön lombikból, külön leoltott mintával hajtottunk végre. Az extrakciónál a lombikokba $10 \mathrm{ml}$ diklór-metánt mértünk, ezt 20 percig rázattuk, majd 300 másodpercig ultrahangoztuk (SilverCrest, Németország). A szétvált fázisok közül az alsó, oldószeres fázist pipettával 15 ml-es Falcon csőbe vittük át, majd centrifugáltuk $20^{\circ} \mathrm{C}$-on és $2000 \mathrm{rpm}$ fordulatszámon, 20 percen keresztül. A fázisok szétválása után az oldószeres fázisból 2 ml-t vittünk át eppendorf csövekbe, majd a mintákat $55^{\circ} \mathrm{C}$-on, kb. 1 órán keresztül termosztátban beszárítottuk. A mintákat a HPLC analízis elvégzéséig hütőben, $4^{\circ} \mathrm{C}$-on, sötét dobozban tároltuk.

A minták száraz tömegét $82^{\circ} \mathrm{C}$ hőmérsékletü, légáram nélküli kemencében, tömegállandóságig történő szárítással határoztuk meg. A minták aflatoxin tartalmát HPLC segítségével detektáltuk.

\subsubsection{A. parasiticus tenyésztése búza szubsztráton}

Az A. parasiticus-ból Petri-csészében, malátás agaron, 7 napos tenyészetet hoztunk létre, amelyből $1 \times 10^{6}$ konídiumszámú szuszpenziót készítettünk. A búzatöretből 5 g-ot mértünk $20 \mathrm{ml}$ térfogatú Erlenmeyer lombikokba, majd $2 \mathrm{ml}$ csapvízzel nedvesítettük és 25 percig, $120^{\circ} \mathrm{C}$-on, 1 atmoszféra nyomáson, hőkezeléssel csíramentesítettük. A búzatöretre 250 $\mu 1$ szuszpenziót (konídiumszám: $0,25 \times 10^{6}$ ) oltottunk. A kísérlethez használt lombikok térfogatát egyenként lemértük, a búzatöret térfogatát ismerve, lombikonként meghatároztuk 
azt az illóolaj mennyiséget, mely az adott koncentráció eléréséhez szükségesnek bizonyult. Az illóolajat a lombik fedőfóliájára felvarrt papírkorongok segítségével vittük a légtérbe. A korongokra a lombikok légterében elérni kívánt koncentráció függvényében $0,42 \mathrm{mg} / \mathrm{cm}^{3}$, $0,21 \mathrm{mg} / \mathrm{cm}^{3}, 0,105 \mathrm{mg} / \mathrm{cm}^{3}$, illetve $0,052 \mathrm{mg} / \mathrm{cm}^{3}$-nek megfelelő mennyiségü illóolajat vittünk fel. A lombikokat légmentesen lezártuk fóliával és celofánnal. A kontroll minták esetében $7 \mu \mathrm{l}$ desztillált víz került a papírkorongokra. A mintákat 10 napig $25^{\circ} \mathrm{C}$-on inkubáltuk. Közben két alkalommal (az 5. és 10. napon) extraháltunk ki 3-3 párhuzamos mintát. Minden extrakciót külön leoltott mintából hajtottunk végre.

Az extrakció előkészítéséhez $2 \%$ agart készítettünk. Annak érdekében, hogy a konídiumok légtérbe jutását megelőzzük, a gabonamintára $10 \mathrm{ml}$ meleg, de nem forró agart öntöttünk. Ezt követően a mintákhoz $15 \mathrm{ml}$ diklór-metánt adtunk, majd a mintákat egyenként 50 ml-es Falcon csövekbe vittük át. A mintákat 30 másodpercig homogenizáltuk, majd 5000 rpm fordulatszámon 5 percig centrifugáltuk a vizes és az oldószeres fázis szétválasztása érdekében. Az oldószeres fázist 15 ml-es Falcon csövekbe vittük át Pasteur pipettával. A 4.6.2 pontban ismertetett paraméterek mellett centrifugáltuk, beszárítottuk és tároltuk a mintákat. A minták aflatoxin tartalmát HPLC segítségével határoztuk meg.

\subsubsection{Aflatoxin tartalom meghatározása}

\subsubsection{Aflatoxin meghatározása szilárd táptalajon tenyésztett $A$. parasiticus esetén}

A mintaelőkészítés során a bepárolt mintákat $200 \mu$ n-hexánban oldottuk vissza, majd hozzáadtunk $50 \mu 1$ trifluor-ecetsavat, és vortexeltük $(15 \mathrm{mp})$. A mintákat ezután $60^{\circ} \mathrm{C}$-on inkubáltuk 15 percig. Az inkubációs idő letelte után a mintákat hagytuk lehűlni szobahőmérsékleten, majd hozzáadtunk $200 \mu$ l acetonitril:víz 1:9 arányú elegyét és vortexeltük (15 mp). A folyadék fázisok maradéktalan szétválása után az alsó fázist eltávolítottuk, majd centrifugáltuk (13000 rpm, 5 perc). A felülúszót átpipettáztuk $300 \mu 1$ térfogatú HPLC mikrofiolába, majd HPLC készülékbe injektáltuk.

A vizsgálatok során moduláris Shimadzu típusú, nagy-nyomású grádiens-képző HPLC rendszert használtunk. A rendszer vezérlését CBM-20A kontroller végezte, amelyhez két LC20ADVp pumpa, DGU-14A gáztalanító, CTO-10ASVp oszlop termosztát, SIL-20A automata mintaadagoló, valamint egy RF-20A fluoreszcens detektor kapcsolódott. Az aflatoxin G1, B1, G2 és B2 detektálására és mennyiségi meghatározására izokratikus HPLC módszert fejlesztettünk ki, ahol az optimális mozgó fázis összetételnek HPLC tisztaságú víz és 
metanol:acetonitril (1:1) 65:35 arányú elegye bizonyult. Az elválasztást LiChrospher® 100 RP-18 250 x 4,6 mm $5 \mu \mathrm{m}$ (Merck, Németország) oszlopon valósítottuk meg $1 \mathrm{ml} /$ perc áramlási sebesség mellett. Az injektált minta térfogata $5 \mu 1$ volt. A detektálás során $365 \mathrm{~nm}$ gerjesztési és $430 \mathrm{~nm}$ emissziós hullámhosszat használtunk. Az oszlop termosztát hőmérséklete $40^{\circ} \mathrm{C}$ volt. Standardként aflatoxin keveréket használtunk (Sigma), amely tartalmazta mind a négy meghatározni kívánt aflatoxin típust. Az adatgyüjtést és a kiértékelést a ClassVP v6.14 programmal végeztük.

Az aflatoxin G1 és B1 esetén 5 pontos kalibrációt, míg aflatoxin G2 és B2 esetén 6 pontos kalibrációt készítettünk. A standardok mennyisége és a detektált jel minden esetben lineáris összefüggést mutatott. Az egyenesek egyenleteit a 4. táblázat tartalmazza. A kalibrációhoz ismert koncentrációjú standardból 5, illetve 6 lépcsős, feles léptékü hígítási sort készítettünk az AFG1, AFB1 esetében 575 ng/ml-től 35,94 ng/ml-ig, míg AFG2, AFB2 esetében 166 ng/ml-től 5,19 ng/ml-ig. Az egyes aflatoxinokra vonatkozó meghatározási és detektálási szinteket az 5. táblázat tartalmazza.

4. táblázat: A vizsgálatba bevont aflatoxinok kalibrációs egyeneseinek egyenletei, illetve a hozzájuk tartozó $\mathrm{R}^{2}$ értékek.

\begin{tabular}{ccc}
\hline Név & Egyenlet & Determinációs koefficiens $\left(\mathbf{R}^{2}\right)$ \\
\hline Aflatoxin G1 & $\mathrm{Y}=5,03961^{*} 10^{-4} \mathrm{X}+17,6305$ & 0,996715 \\
Aflatoxin B1 & $\mathrm{Y}=1,2493^{*} 10^{-4} \mathrm{X}+17,2499$ & 0,997098 \\
Aflatoxin G2 & $\mathrm{Y}=3,71155^{*} 10^{-4} \mathrm{X}+3,859828$ & 0,992568 \\
Aflatoxin B2 & $\mathrm{Y}=8,90344^{*} 10^{-5} \mathrm{X}+3,63295$ & 0,991749 \\
\hline
\end{tabular}

5. táblázat: A módszer meghatározási és detektálási szintjei.

\begin{tabular}{lcccc}
\hline & $\begin{array}{c}\text { Aflatoxin G1 } \\
(\mathbf{n g} / \mathbf{m l})\end{array}$ & $\begin{array}{c}\text { Aflatoxin B1 } \\
(\mathbf{n g} / \mathbf{m l})\end{array}$ & $\begin{array}{c}\text { Aflatoxin G2 } \\
\mathbf{( n g / m l})\end{array}$ & $\begin{array}{c}\text { Aflatoxin B2 } \\
\mathbf{( n g / m l})\end{array}$ \\
\hline Meghatározási szint & 1,125 & 1,125 & 2,295 & 1,28 \\
Detektálási szint & 0,56 & 0,56 & 1,28 & 0,64 \\
\hline
\end{tabular}

4.6.4.2. Aflatoxin meghatározása folyadékközegben és búza szubsztráton tenyésztett $A$. parasiticus esetén

Mintaelőkészítés során az extraktumok származékképzését az alábbiak szerint valósítottuk meg: a mintákat visszaoltottuk $0,4 \mathrm{ml} n$-hexánban, $30 \mathrm{mp}$ vortexelés után $0,1 \mathrm{ml}$ 
TFA-t adtunk hozzájuk, majd újra vortexeltük öket (30 mp). Ezt követően a mintákat $60^{\circ} \mathrm{C}$-on inkubáltuk 15 percig. Az inkubációs idő letelte után a mintákat hagytuk szobahőmérsékletüre hülni, majd 0,4 ml víz:acetonitril (9:1) elegyét adtuk hozzájuk és újra $30 \mathrm{mp}$-ig vortexeltük a mintákat. A fázisok szétválását követően az alsó fázist gyüjtöttük, centrifugáltuk (13000 rpm, 10 perc), majd HPLC fiolába pipettáztuk. Az így előkészített mintát HPLC készülékbe injektáltuk. A HPLC mérést a 4.7.4.1. fejezetben ismertetett módon hajtottuk végre, annyi

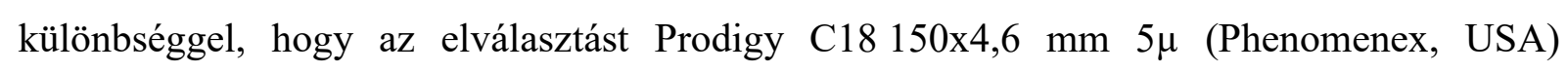
oszlopon valósítottuk meg $1 \mathrm{ml} /$ perc áramlási sebesség mellett. Az injektált minta térfogata 3 $\mu 1$ volt. A gerjesztési és emissziós hullámhosszak rendre 350 nm és 430 nm voltak.

\subsection{Az illóolajok hatása a fonalasgombák morfológiai változásaira}

\subsubsection{Elektronmikroszkópos vizsgálatok}

Az illóolajjal történt kezeléseket követően a morfológiai változásokat nagy felbontású pásztázó elektronmikroszkóp (SEM) segítségével detektáltuk a F. culmorum izolátum esetében. A minta előkészítése a következő lépésekből állt:

- „Agar hígításos” módszert alkalmaztunk a tenyésztésnél, amikor különböző illóolaj mennyiségeket $\left(5,00 ; 2,50 ; 1,25 ; 0,65 ; 0,30\right.$ és $\left.0,15 \mathrm{mg} / \mathrm{cm}^{3}\right)$ kevertünk malátás agarba. A tenyészeteket 10 napon keresztül, $25{ }^{\circ} \mathrm{C}$-on inkubáltuk.

- Az inkubációt követően dugófúróval kivágott, 8 milliméteres telepdarabokat helyeztünk a 48 mintahelyes mikrotiter lap mélyedéseibe, három párhuzamosban.

- A minták fixálása 2,5\%-os glutáraldehidben történt (0,05 M kakodilát puffer-7,5 pH) 2 órás inkubációval, szobahőmérsékleten.

- A víztelenítést a következők szerint végeztük: a minták 2x15 percig álltak először 50\%-os, majd 70\%-os és végül 80\%-os etanolban, ezután 90 percig 96\%-os etanolban, valamint 2 óra hosszáig 100\%-os etanolban. Ezután a mintákat 1-1 órán keresztül tbutilalkohol és 100\%-os etanol 1:2, 1:1,2:1 arányú keverékében, végül pedig 2 órán át t-butilalkoholban tartottuk.

- Liofilizáltuk a mintákat a teljes kiszáradás elérése érdekében (kb. 4-6 óra).

- A mintákat rögzítettük a mintatartóra ezüstpaszta segítségével.

- A mintákat arany membránnal vontuk be, és felvételeket készítettünk Hitachi S4700 elektronmikroszkóppal. 


\subsubsection{Fénymikroszkópos vizsgálatok}

Az A. parasiticus spóraképzésének és morfológiájának meghatározását fénymikroszkópos vizsgálatokkal végeztük. A tenyésztés Petri-csészében, malátás agaron történt, $25^{\circ} \mathrm{C}$ hömérsékleten, 10 napon keresztül. A telepről $2 \times 5 \mathrm{ml}$ desztillált víz segítségével, steril vattán keresztül mostuk le a konídiumokat, polipropilén Falcon csőbe (VWR). Fénymikroszkóp és Bürker kamra segítségével meghatároztuk a spóraszámot. Laktofenol-gyapotkékkel történő festést követően fénymikroszkóp (Axiolab, LR 66238C, Carl Zeiss) segítségével figyeltük meg a micéliumok egyes részeinek és a konídiumok alaktani változását. A képfelvételeket a mikroszkóp kamerájával (AxioCam ERc $5 \mathrm{~s}$, Carl Zeiss) készítettük.

\subsection{Búzaminták vízaktivitás mérése}

Feltételeztük, hogy a száraz búza vízaktivitása olyan alacsony, hogy azon a fonalasgomba nem nőtt volna, ezért a mintákat nedvesítettük, majd meghatároztuk a száraz és nedves búza vízaktivitását. A vízaktivitásnak hatása van az aflatoxin termelésre is. A búza nedvesítéséhez $5 \mathrm{~g}$ búzát méröhengerbe tettünk, majd pipettával $2 \mathrm{ml}$ csapvizet mértünk rá. A víz mennyiségét több próba eredményeként állapítottuk meg. A víz hozzáadását követően a mérőhengereket lezártuk alufóliával. A mintákat kuktában hőkezeltük 25 percig, majd lemértük a térfogat növekedését A kuktázást követően a nedves búzát, majd a száraz búzát zárt, kerek műanyag edényzetbe tettük, és a NOVASINA AG LabMaster-aw 1106011 (Svájc) vízaktivitás mérőbe heleztük. A müszer a víztartalom és a vízaktivitás közti szorpciós izoterma görbe felvételével számolja ki az aktuális vízaktivitást.

\subsection{Alkalmazott statisztikai módszerek}

Vizsgálati eredményeinket egyutas és kétutas ANOVA elemzéssel értékeltük ki, R Works 2.8.1, illetve GraphPad Prisma 6.0 szoftverek segítségével $(\mathrm{P}<0,05$ szignifikancia szint mellett). Adataink elemzésénél páros t-próbát is alkalmaztunk. 


\section{EREDMÉNYEK ÉS ÉRTÉKELÉS}

\subsection{Illóolajok összetétele}

A boróka és a citrom illóolaj főként monoterpénekből áll, míg a fahéj, a muskotályzsálya és a majoránna illóolaj főként oxigenált monoterpéneket (aldehideket, alkoholokat és acetát-észtereket) tartalmaz. Az 6. táblázat az alkalmazott illóolajok fö összetevőit sorolja fel.

6. táblázat: Az alkalmazott illóolajok fö összetevői a gyártó adatai alapján.

\begin{tabular}{|c|c|c|c|c|c|c|}
\hline komponensek & $\begin{array}{c}\text { Retenciós } \\
\text { idő } \\
\text { (perc) } \\
\end{array}$ & Fahéjolaj & $\begin{array}{l}\text { Muskotályzsálya- } \\
\text { olaj } \\
\end{array}$ & zalékos arány & Citromolaj & Majoránnaolaj \\
\hline$\alpha$-pinén & 5,157 & - & - & 40,70 & - & - \\
\hline$\beta$-fellandrén & 5,982 & - & - & - & - & 8,00 \\
\hline$\beta$-pinén & 6,023 & - & - & 36,00 & 9,54 & - \\
\hline$\alpha$-terpineol & 6,830 & - & - & - & - & 11,03 \\
\hline$p$-cymén & 7,009 & - & - & 18,90 & - & - \\
\hline limonén & 7,074 & - & - & - & 83,20 & - \\
\hline$\gamma$-terpinén & 7,645 & - & - & - & 5,60 & 19,53 \\
\hline linalool & 8,446 & - & 13,60 & - & - & - \\
\hline terpinén-4-ol & 9,781 & - & - & - & - & 33,58 \\
\hline linalil acetát & 10,989 & - & 84,00 & - & - & - \\
\hline fahéjaldehid & 11,360 & 93,10 & - & - & - & - \\
\hline $\begin{array}{l}\text { cinnamil } \\
\text { acetát }\end{array}$ & 13,811 & 2,50 & - & - & - & - \\
\hline Összesen: & & 95,6 & 97,6 & 95,6 & 98,34 & 72,14 \\
\hline
\end{tabular}

\subsection{Illóolajok antifungális hatása}

\subsection{A minimális gátló koncentráció (MIC) meghatározása agar hígításos módszer és fordított Petri-csésze módszer alkalmazása esetén}

Kísérleteinkhez az illóolajokat szubletális koncentráció tartományban kívántuk használni, ezért a MIC értékek pontos meghatározására, amennyiben azok kívül estek a korábbi kísérletekben már sikeresen alkalmazott koncentráció tartományon, nem került sor.

A 7. táblázat az agar hígításos módszerrel kapott MIC értékeket mutatja be. A táblázat adataiból látható, hogy a fahéj-, majd a majoránna- és a muskotályzsálya olaj mutatta a legalacsonyabb MIC értéket, azaz ezek fejtették ki a legerőteljesebb gátló hatást. A boróka és a citrom illóolaj kevésbé bizonyult hatásosnak a vizsgált fonalasgombák esetében. 
A fahéjolaj erős antifungális hatása a benne található fahéjaldehidnek tulajdonítható. A táptalajban történő, igen kis koncentrációjú $\left(0,30-0,65 \mathrm{mg} / \mathrm{cm}^{3}\right)$ alkalmazása is teljes gátlást okozott valamennyi tesztelt Fusarium faj esetén. A törzseket összehasonlítva a Fusarium fajok jóval érzékenyebbnek bizonyultak, mint az Aspergillusok, amit a növekedési kísérletek adatai is alátámasztanak.

7. táblázat: A vizsgált illóolajok MIC értékei $\left(\mathrm{mg} / \mathrm{cm}^{3}\right)$ agar hígításos módszer alkalmazása esetén

\begin{tabular}{lccccc}
\hline fonalasgomba izolátum & Boróka & Citrom & Fahéj & Majoránna & $\begin{array}{c}\text { Muskotály } \\
\text { zsálya }\end{array}$ \\
\hline C. hawaiiensis & 20 & 20 & $<0,15$ & 2,5 & 5 \\
F. graminearum & 20 & 40 & 0,65 & 5 & 10 \\
$F$. culmorum & 5 & $>40$ & 0,30 & 5 & 20 \\
$F$. verticillioides & 20 & $>40$ & 0,30 & 10 & 40 \\
A. nomius & $>40$ & $>40$ & 10 & 5 & 40 \\
A. parasiticus & $>40$ & $>40$ & 2,5 & 10 & $>40$ \\
A. westerdijkiae & $>40$ & $>40$ & 0,65 & 5 & 10 \\
A. longivesica & 40 & $>40$ & 0,15 & 2,5 & 2,5 \\
A. albertensis & $>40$ & $>40$ & 0,65 & 2,5 & 20 \\
A. awamori & $>40$ & $>40$ & 0,65 & 2,5 & 5 \\
\hline
\end{tabular}

Meghatároztuk a MIC értékeket $\left(\mathrm{mg} / \mathrm{cm}^{3}\right)$ a fordított Petri-csésze módszerrel is, ez esetben a csészék légtere tartalmazta az illóolajokat különbözö koncentrációkban (8. táblázat). Az alkalmazott koncentrációk itt a legtöbb esetben alacsonynak bizonyultak ahhoz, hogy teljes gátlást tudjunk elérni.

8. táblázat: A vizsgált illóolajok $\mathrm{MIC}$ értékei $\left(\mathrm{mg} / \mathrm{cm}^{3}\right)$ Fordított Petri-csésze módszer alkalmazása esetén

\begin{tabular}{cccccc}
\hline \multirow{2}{*}{ fonalasgomba izolátum } & \multicolumn{5}{c}{ Illóolaj $\mathbf{( m g / \mathbf { c m } ^ { 3 }}$ légtér) } \\
& Boróka & Citrom & Fahéj & Majoránna & Muskotály \\
& & & & & -zsálya \\
\hline C.hawaiensis & $>0,42$ & $>0,42$ & $<0,052$ & 0,42 & 0,42 \\
F. graminearum & $>0,42$ & $>0,42$ & 0,105 & $>0,42$ & $>0,42$ \\
F. culmorum & $>0,42$ & $>0,42$ & 0,21 & $>0,42$ & $>0,42$ \\
A. nomius & $>0,42$ & $>0,42$ & $>0,42$ & $>0,42$ & $>0,42$ \\
A. westerdijkiae & $>0,42$ & $>0,42$ & 0,105 & $>0,42$ & $>0,42$ \\
A. longivesica & $>0,42$ & $>0,42$ & 0,105 & 0,42 & 0,42 \\
A. parasiticus & $>0,42$ & $>0,42$ & $>0,42$ & $>0,42$ & $>0,42$ \\
A. albertensis & $>0,42$ & $>0,42$ & $>0,42$ & $>0,42$ & $>0,42$ \\
F. verticillioides & $>0,42$ & $>0,42$ & 0,21 & $>0,42$ & $>0,42$ \\
A. awamori & $>0,42$ & $>0,42$ & $>0,42$ & 0,42 & $>0,42$ \\
\hline
\end{tabular}


Összességében, a tesztelt illóolajok különböző hatékonyságban gátolták az egyes fonalasgomba izolátumok növekedését. Legkevésbé hatékonynak a citrom-, majd a boróka illóolaj mutatkozott. Hatékonyságban ezeket követte a muskotályzsálya-, majd a majoránnaolaj. A leghatékonyabbnak mind az Aspergillus, mind a Fusarium izolátumok esetében a fahéjolaj bizonyult.

\subsection{Illóolajok hatása a fonalasgombák telepnövekedésére}

\subsubsection{Telepnövekedési sebesség alakulása}

5.4.1.1. Aspergillus-ok telepnövekedési sebességének alakulása illóolaj gőztérben

A telepnövekedési sebességek alakulását vizsgálva (11. ábra) általánosan elmondható, hogy az Aspergillus izolátumokra leggyengébb hatással a citrom és a boróka illóolaj bírt. Nagyobb koncentráció mellett is csupán két törzsnél (A. albertensis, A. longivesica) tapasztaltuk a telepnövekedési sebesség szignifikáns csökkenését. A muskotályzsálya illóolaj hatékonysága az egyes izolátumok egyéni érzékenységétől függött. Az alkalmazott koncentrációtól függetlenül nem okozott szignifikáns telepnövekedés csökkenést sem az $A$. nomius, sem az A. parasiticus esetén. Más fajoknál (A. westerdijkiae, A. longivesica) azonban, főként nagyobb koncentrációkban, hatékony gátlást mutatott. A fahéj és a majoránna illóolaj telepnövekedést csökkentő hatása koncentráció-függést mutatott, szinte minden vizsgált Aspergillus fajnál hatékonynak bizonyultak.

Az illóolajos kezelésekre legérzékenyebbnek az A. longivesica, legkevésbé érzékenynek az $A$. nomius bizonyult. 
A

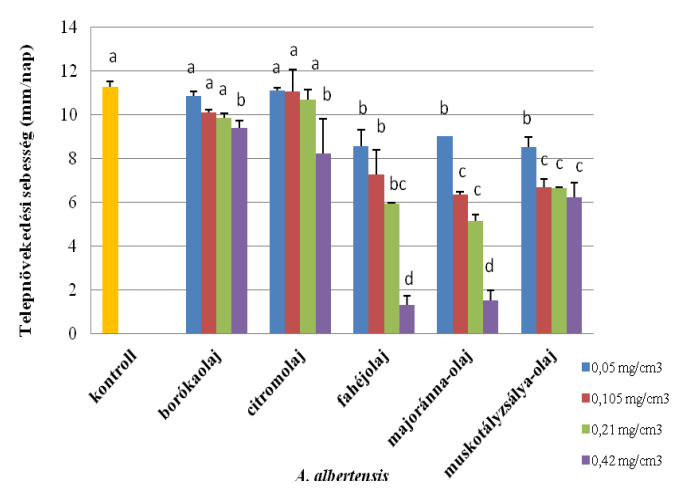

C

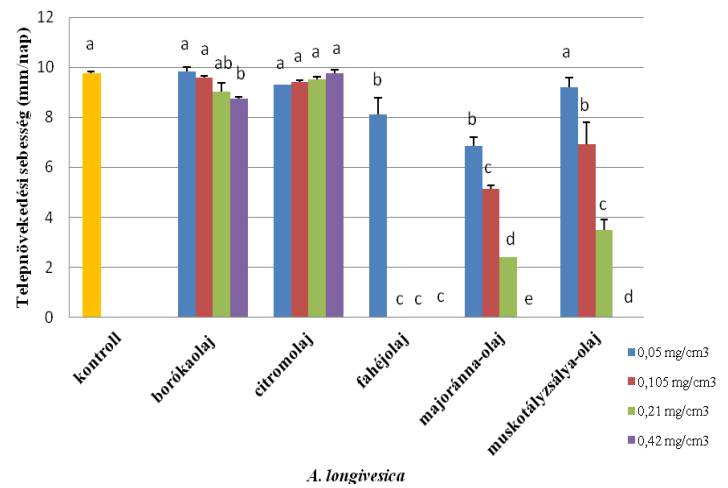

E

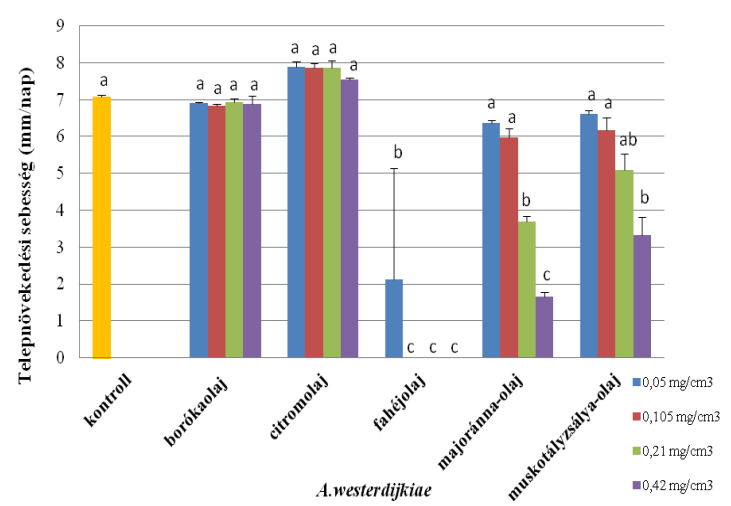

B

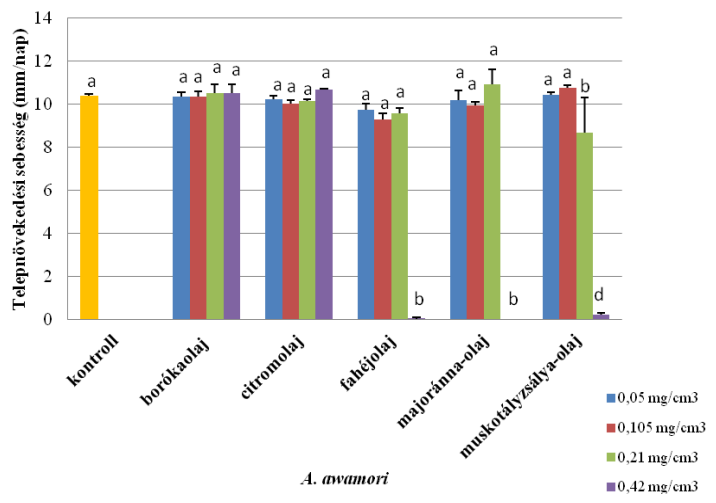

D

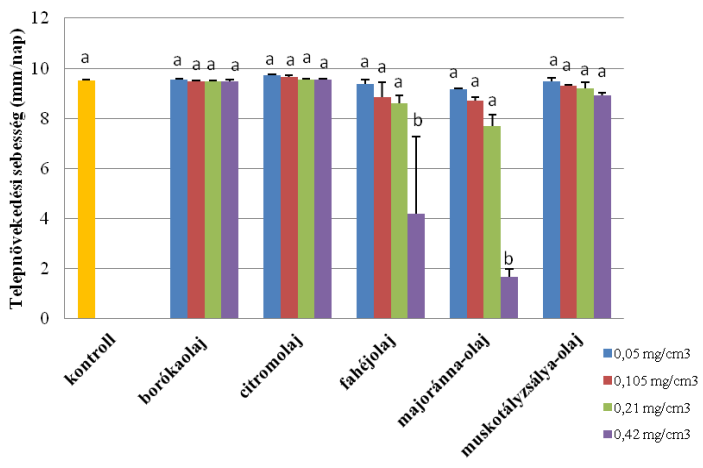

F

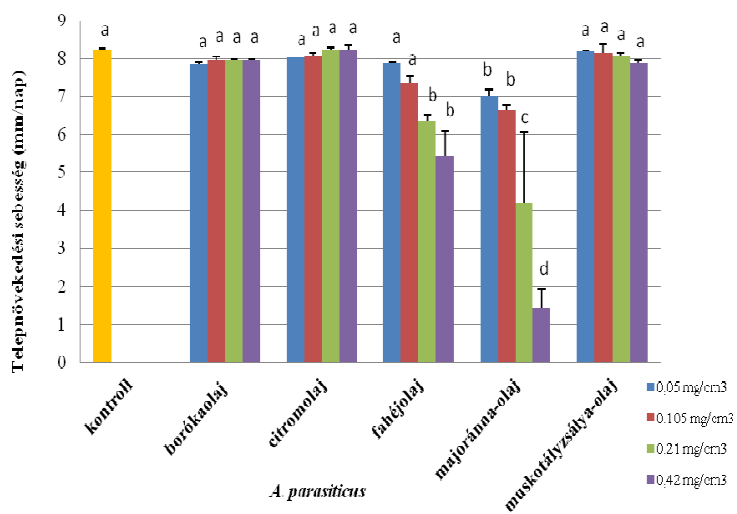

11. ábra: Aspergillusok telepnövekedési sebességének ( $\mathrm{mm} / \mathrm{nap})$ alakulása illóolaj gőztérben. A: A. albertensis, B: A. awamori, C: A. longivesica, D: A. nomius, E: A. westerdijkiae, $\mathrm{F}: \mathrm{A}$. parasiticus. Az oszlopok tetején található különböző betük szignifikáns eltérést $(\mathrm{P}<0,05)$ jeleznek, míg azonos betük esetében az eltérés nem volt szignifikáns a kontroll és az egyes illóolaj féleségek alkalmazott koncentrációinak összehasonlításakor.

\subsubsection{Fusarium-ok telepnövekedési sebességének alakulása illóolaj gőztérben}

A három tesztelt Fusarium izolátum telepnövekedési sebességének alakulását az illóolajos kezelések hatására a 12. ábra mutatja be. 
A

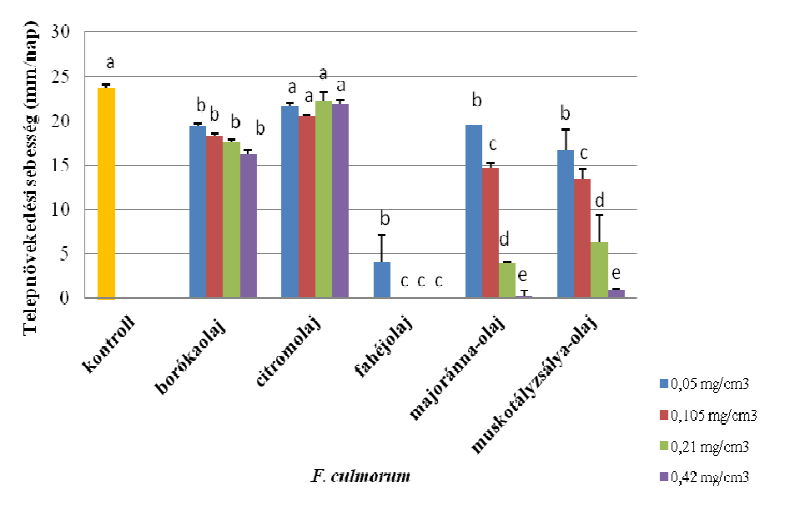

B

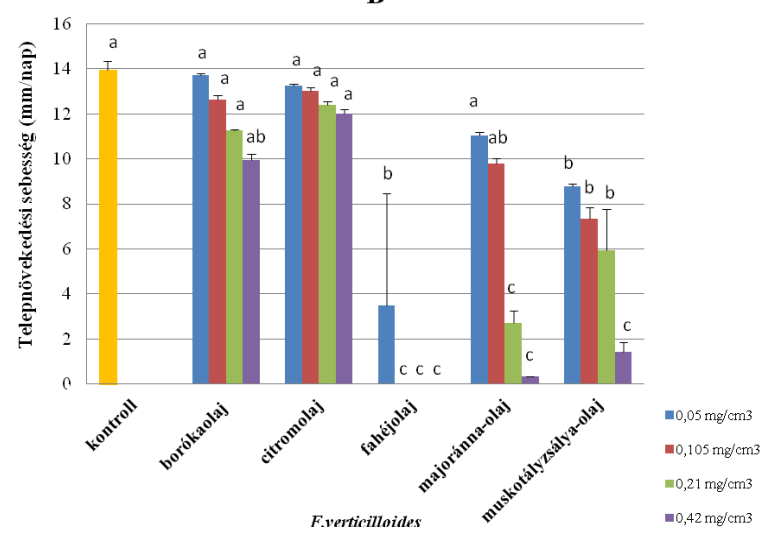

C

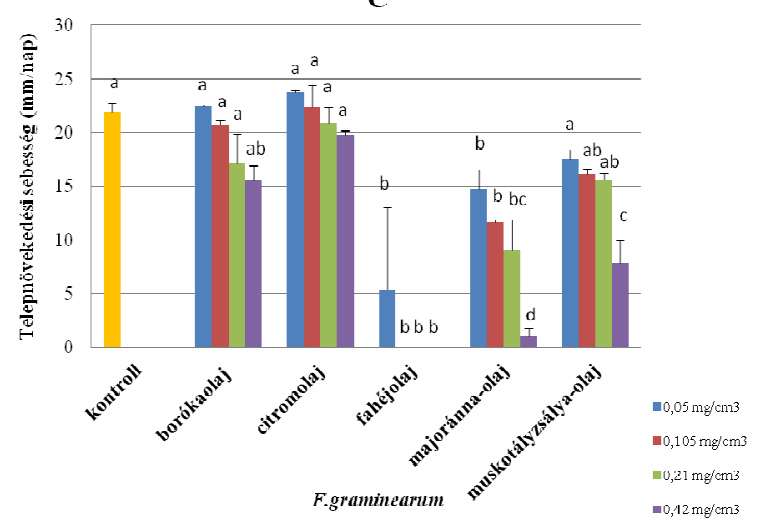

12. ábra: Fusariumok telepnövekedési sebességének ( $\mathrm{mm} / \mathrm{nap})$ alakulása illóolaj gőztérben. A: F. culmorum, B: F. verticillioides, C: F. graminearum. Az oszlopok tetején található különböző betűk szignifikáns eltérést $(\mathrm{P}<0,05)$ jeleznek, míg azonos betűk esetében az eltérés nem volt szignifikáns a kontroll és az egyes illóolaj féleségek alkalmazott koncentrációinak összehasonlításakor.

Leghatékonyabbnak a fahéj illóolaj bizonyult, amely mindhárom izolátum esetében szignifikánsan csökkentette a telepnövekedés sebességét már a legkisebb alkalmazott koncentrációban is. Legkevésbé hatékony a citrom illóolaj volt. A boróka, majoránna és muskotályzsálya illóolajok koncentráció-függően, szignifikánsan csökkentették a telepnövekedési sebességet.

\subsubsection{C. hawaiiensis telepnövekedési sebességének alakulása illóolaj gőztérben}

A C. hawaiiensis a Fusarium izolátumokhoz hasonlóan reagált az illóolajos kezelésekre. Citromolajjal a telepnövekedés szignifikáns változását nem tudtuk elérni, de kevésbé volt hatékony a boróka illóolaj is (13. ábra). Ugyanakkor a fahéjolaj már a legkisebb koncentrációban $\left(0,05 \mathrm{mg} / \mathrm{cm}^{3}\right)$ is teljes gátlást okozott a növekedésben. A majoránna- és a 
muskotályzsálya olajok növekvő koncentrációja a gátlás mértékét is fokozta. Ezen olajok szignifikánsan csökkentették a telepnövekedés sebességét. Legnagyobb koncentrációban történő alkalmazásuknál $\left(0,42 \mathrm{mg} / \mathrm{cm}^{3}\right)$ telepnövekedést nem tapasztaltunk.

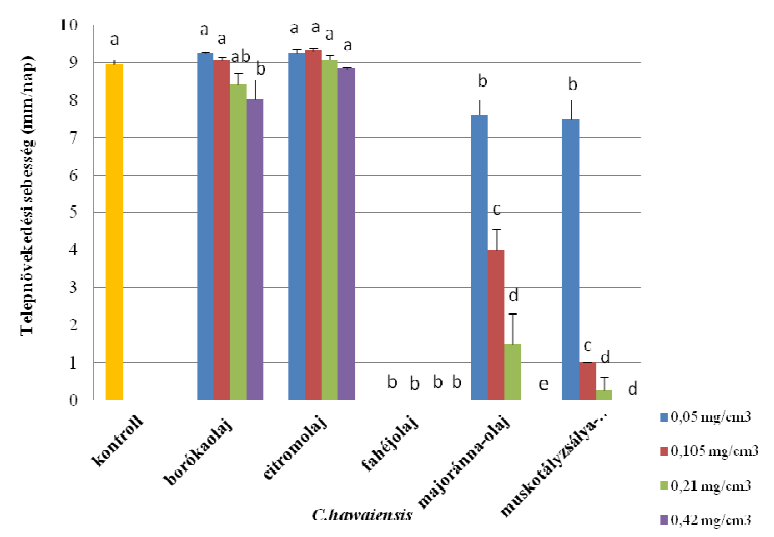

13. ábra: $C$. hawaiiensis telepnövekedési sebességének $(\mathrm{mm} / \mathrm{nap})$ alakulása illóolaj gőztérben. Az oszlopok tetején található különböző betük szignifikáns eltérést $(\mathrm{P}<0,05)$ jeleznek, míg azonos betük esetében az eltérés nem volt szignifikáns a kontroll és az egyes illóolaj féleségek alkalmazott koncentrációinak összehasonlításakor.

5.4.1.4. Fonalasgombák telepnövekedési sebességének alakulása agar-hígításos módszer esetén

A fahéj-, a majoránna- és a muskotályzsálya olajoknál a legtöbb esetben nem volt mérhető telepátmérő, mivel az alkalmazott koncentráció-tartományokban teljes növekedésgátlás következett be.

A 14-21. ábrák a boróka és a citrom illóolaj hatására elért telepnövekedési rátákat mutatják be a kísérleteinkben szereplö Aspergillus és Fusarium izolátumok vonatkozásában.
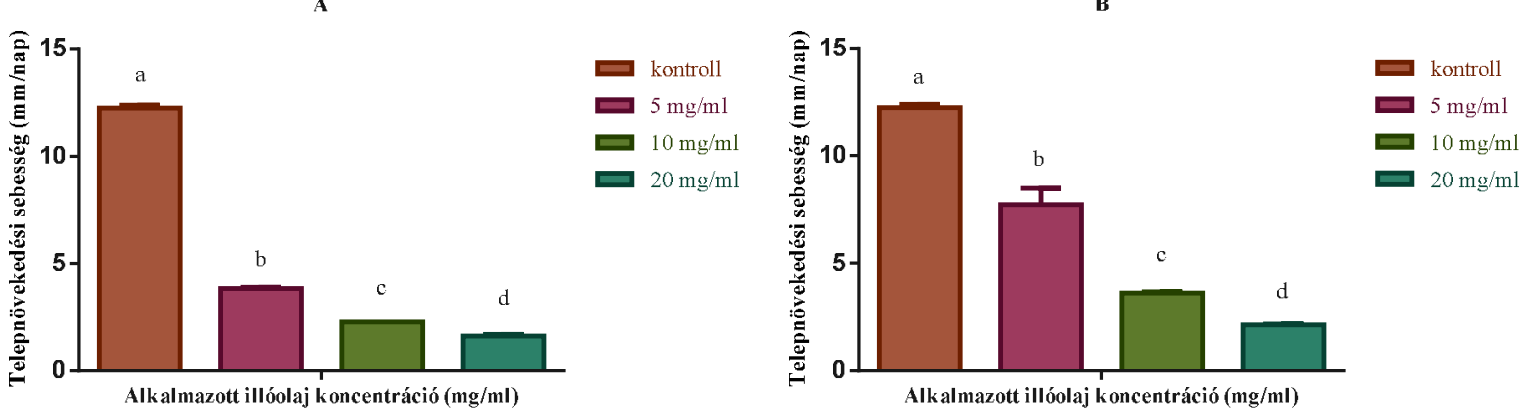

14. ábra: Boróka (A) és citrom (B) illóolajok hatása $F$. verticillioides telepnövekedési sebességére ( $\mathrm{mm} / \mathrm{nap})$ agar-hígításos módszer alkalmazása esetén.

Az oszlopok tetején található különböző betük szignifikáns eltérést $(\mathrm{P}<0,05)$ jeleznek, míg azonos betűk esetében az eltérés nem volt szignifikáns a kontrollhoz képest. 


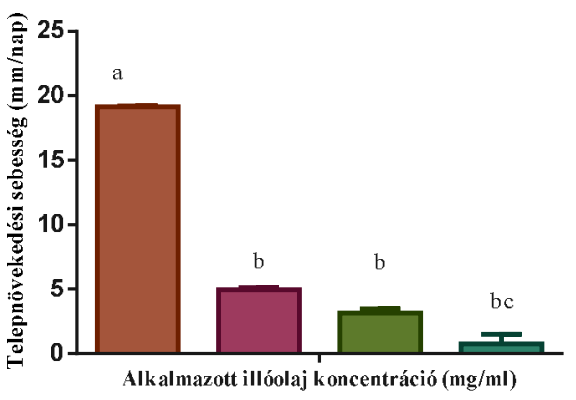

B

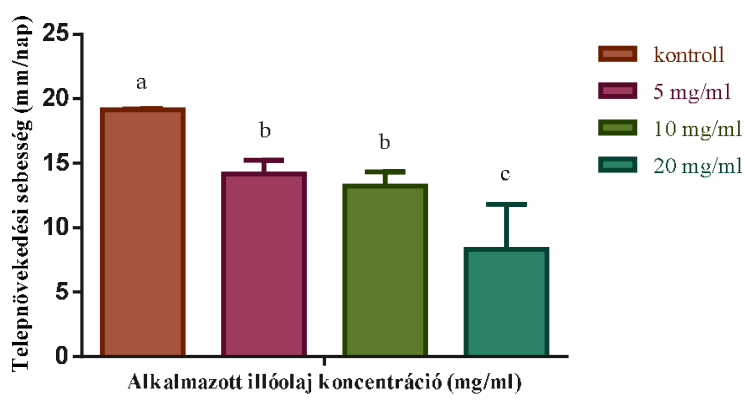

15. ábra: Boróka (A) és citrom (B) illóolajok hatása $F$. graminearum telepnövekedési sebességére ( $\mathrm{mm} / \mathrm{nap})$ agar-hígításos módszer alkalmazása esetén. Az oszlopok tetején található különböző betük szignifikáns eltérést $(\mathrm{P}<0,05)$ jeleznek, míg azonos betük esetében az eltérés nem volt szignifikáns a kontrollhoz képest.
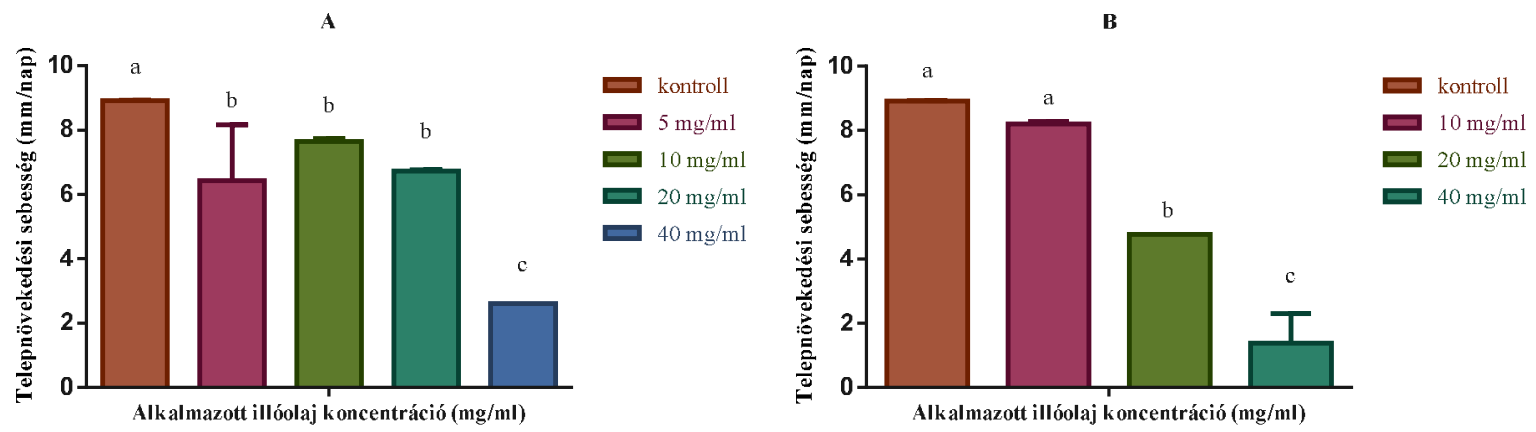

16. ábra: Boróka (A) és citrom (B) illóolajok hatása A. awamori telepnövekedési sebességére (mm/nap) agar-hígításos módszer alkalmazása esetén. Az oszlopok tetején található különböző betűk szignifikáns eltérést $(\mathrm{P}<0,05)$ jeleznek, míg azonos betük esetében az eltérés nem volt szignifikáns a kontrollhoz képest.

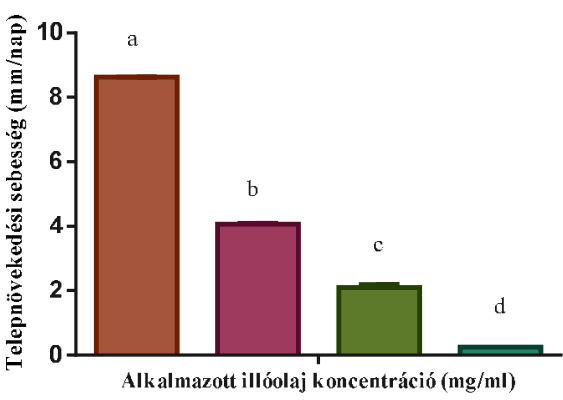

B

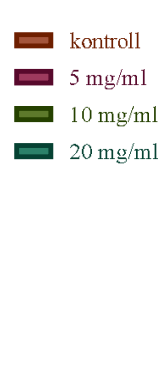

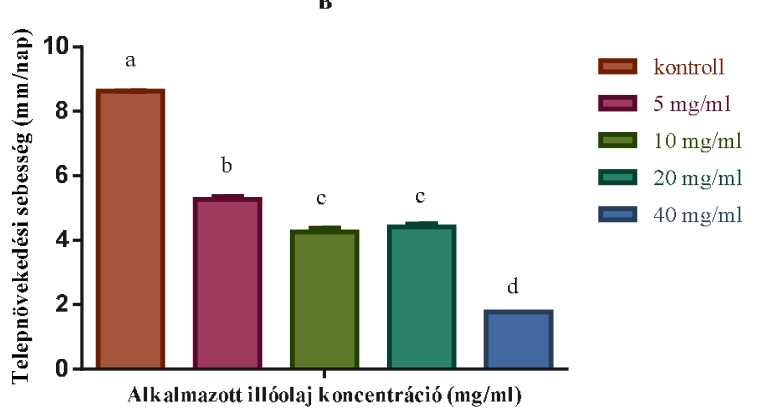

17. ábra: Boróka (A) és citrom (B) illóolajok hatása A. longivesica telepnövekedési sebességére ( $\mathrm{mm} / \mathrm{nap})$ agar-hígításos módszer alkalmazása esetén. Az oszlopok tetején található különböző betük szignifikáns eltérést $(\mathrm{P}<0,05)$ jeleznek, míg azonos betük esetében az eltérés nem volt szignifikáns a kontrollhoz képest. 
B
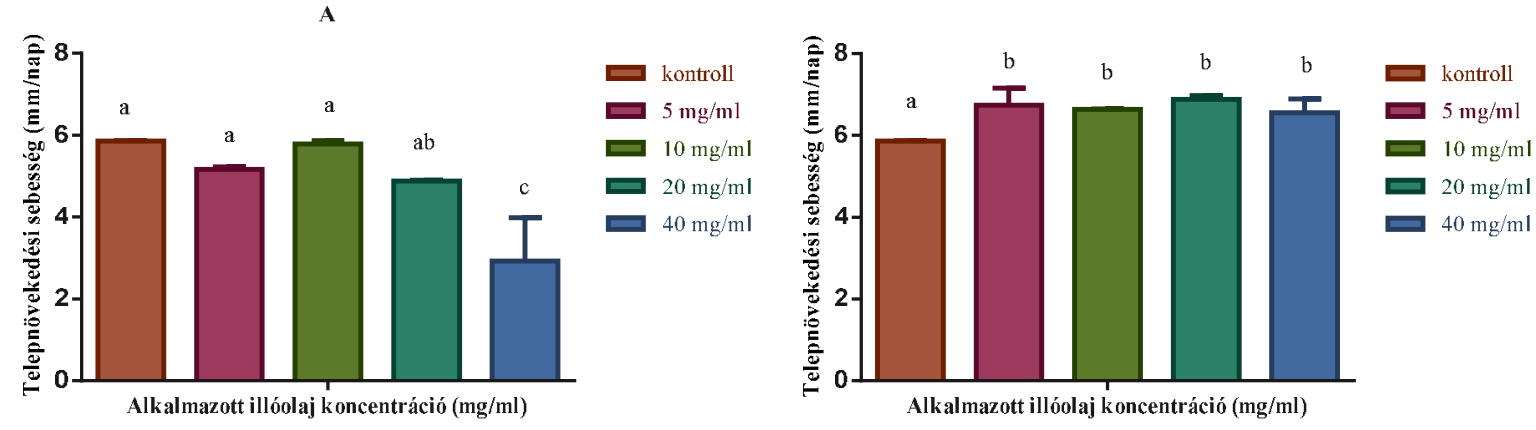

18. ábra: Boróka (A) és citrom (B) illóolajok hatása A. nomius telepnövekedési sebességére (mm/nap) agar-hígításos módszer alkalmazása esetén. Az oszlopok tetején található különböző betük szignifikáns eltérést $(\mathrm{P}<0,05)$ jeleznek, míg azonos betük esetében az eltérés nem volt szignifikáns a kontrollhoz képest.
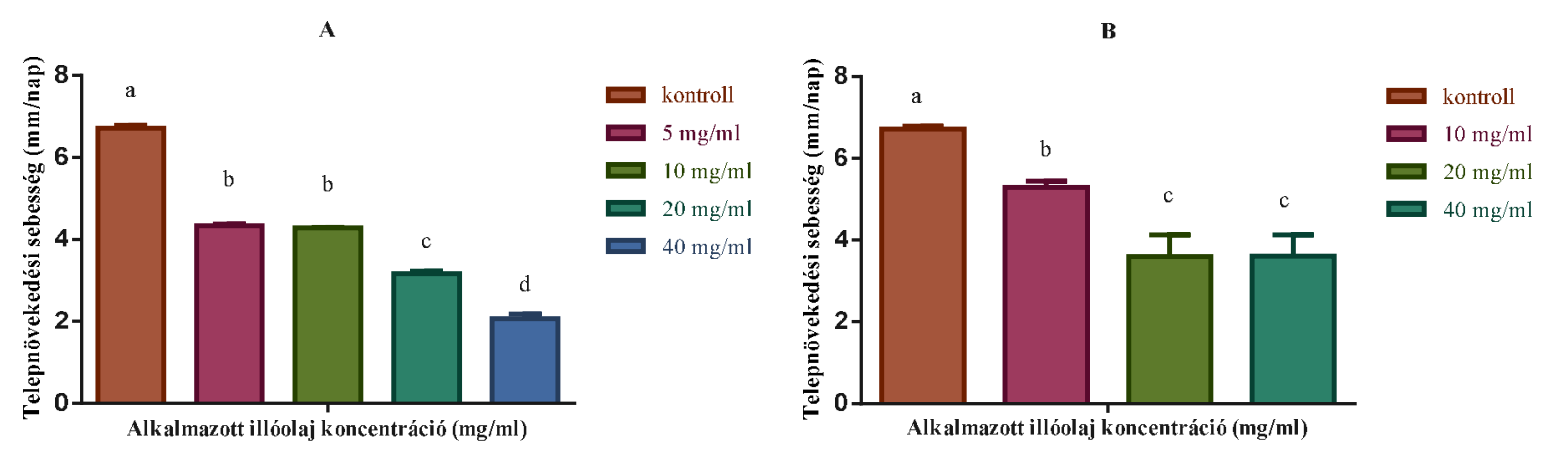

19. ábra: Boróka (A) és citrom (B) illóolajok hatása $A$. westerdijkiae telepnövekedési sebességére ( $\mathrm{mm} / \mathrm{nap})$ agar-hígításos módszer alkalmazása esetén. Az oszlopok tetején található különböző betük szignifikáns eltérést $(\mathrm{P}<0,05)$ jeleznek, míg azonos betűk esetében az eltérés nem volt szignifikáns a kontrollhoz képest.
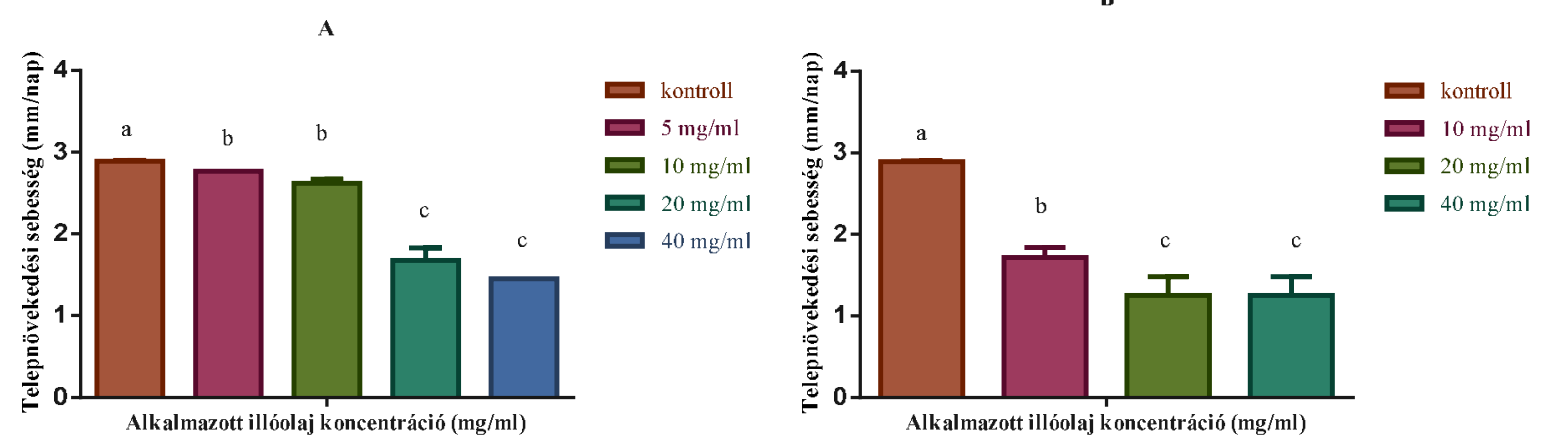

20. ábra: Boróka (A) és citrom (B) illóolajok hatása A. albertensis telepnövekedési sebességére ( $\mathrm{mm} / \mathrm{nap})$ agar-hígításos módszer alkalmazása esetén. Az oszlopok tetején található különböző betük szignifikáns eltérést $(\mathrm{P}<0,05)$ jeleznek, míg azonos betük esetében az eltérés nem volt szignifikáns a kontrollhoz képest. 

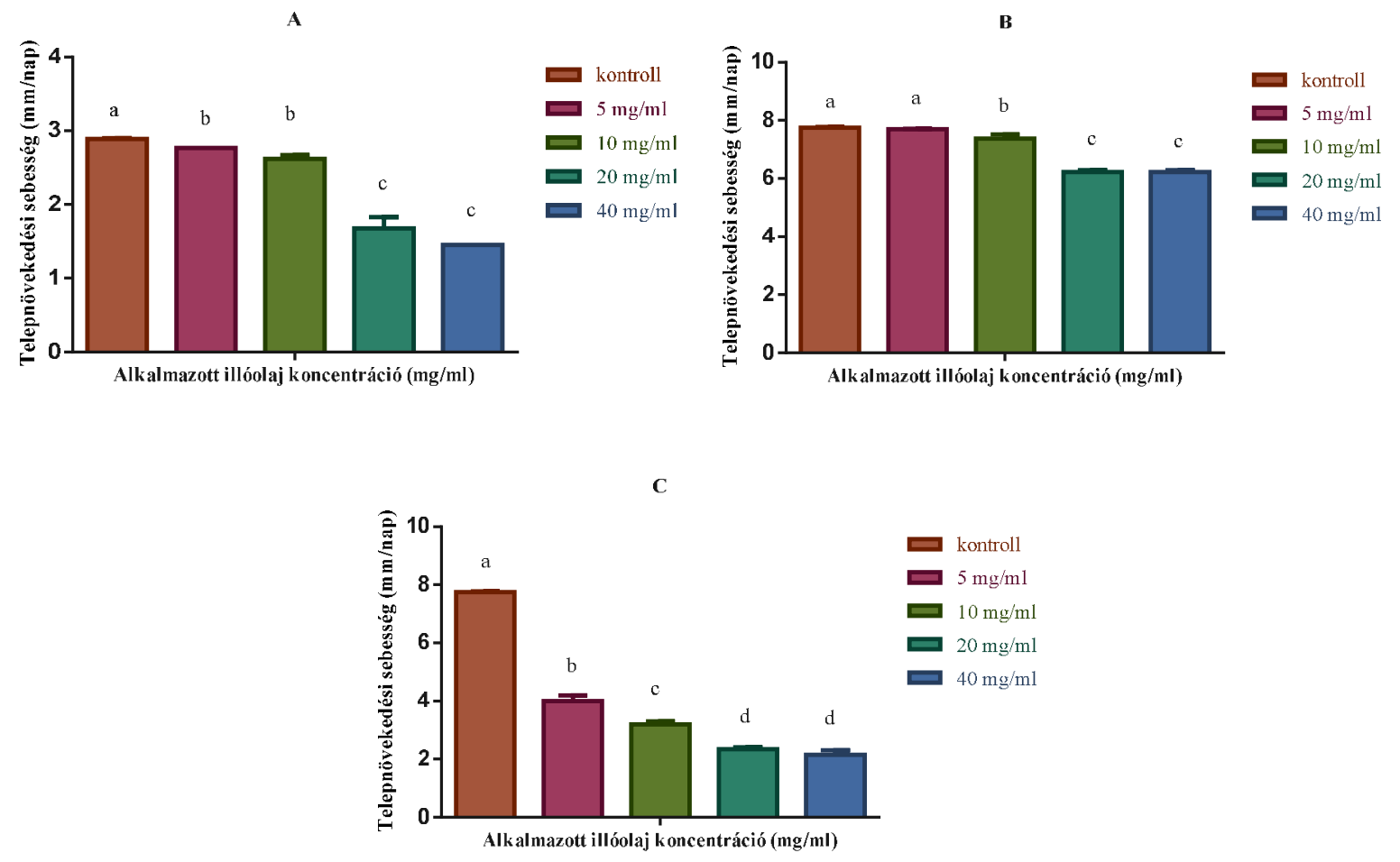

21. ábra: Boróka (A) citrom (B) és muskotályzsálya (C) illóolajok hatása A. parasiticus telepnövekedési sebességére ( $\mathrm{mm} / \mathrm{nap}$ ) agar-hígításos módszer alkalmazása esetén. Az oszlopok tetején található különböző betük szignifikáns eltérést $(\mathrm{P}<0,05)$ jeleznek, míg azonos betük esetében az eltérés nem volt szignifikáns a kontrollhoz képest.

Az agar-hígitásos módszer esetében a boróka és a citrom illóolajok gátló hatását összevetve megállapíthatjuk, hogy az egyes izolátumok hasonlóan reagáltak. Az esetek többségében a boróka illóolajhoz képest a citrom illóolaj kevésbé hatékonynak bizonyult.

Suhr és Nielsen (2003) kísérleteikben kimutatták, hogy az illóolajok antifungális hatása az alkalmazott módszer függvénye is. A fenolos komponensek jelenléte az olajokban (pl. fahéjolajnál a fahéjaldehid) jobb hatást eredményezett, ha azt közvetlenül a táptalajba keverték. Eredményeik arra mutattak rá, hogy a kisebb és nem fenolos komponensekkel bíró olajok (pl. citromolaj - limonén) gőzfázisban történő alkalmazáskor voltak hatékonyabbak. Kísérleteink során, ha gőzfázisban alkalmaztuk az illóolajokat, ugyanazon hatás eléréséhez (pl. a teljes gátláshoz) jóval kisebb mennyiségben voltak elegendőek.

Atanda és munkatársai (2006), valamint Sindhu és munkatársai (2011) megfigyelték, hogy az Aspergillus fajok aflatoxin termelésének és növekedésgátlásának mértéke függ az alkalmazott illóolaj koncentrációjától. Kísérleteik során a legtöbb esetben az illóolajokat a táptalajhoz adták. 
Az illóolajok gőzfázisban általában hatékonyabbak a mikrobákkal szemben, mint folyadékként történő alkalmazásukkor. Az illóolajok antimikrobiális hatása függ azok funkciós csoportjának gőzfázisban való jelenlététől, valamint a gőznyomástól, ami lehetővé teszi a sejtmembránon történő áthatolásukat. Ez eredményezi azt, hogy már nagyon kis koncentrációban hatékonyak tudnak lenni a mikroorganizmusok növekedésgátlásában (Bueno 2015).

Az illóolajok légtérben történő alkalmazása a szubsztráthoz történő közvetlen adagolással szemben alternatív megoldás lehet, mivel a hatékonyabb hatás eléréséhez kevesebb illóolaj szükséges.

\subsubsection{Antifungális indexek alakulása illóolaj göztérben}

A legtöbb esetben jól nyomon követhető volt, hogy a légtér illóolaj koncentrációjának növekedésével együtt nőtt a gátlás mértéke is, azaz a telepek átmérője csökkent.

A gátlások \%-os mértékét vizsgálva, ezen adatokból is kitünik, hogy a legkevésbé hatékonynak a citrom, illetve a boróka illóolaj mutatkozott (22. ábra).

A legjobb eredményeket az aldehid-, illetve az alkoholos jellegü fő komponenseket tartalmazó illóolajoknál tapasztaltuk (fahéj-, majoránna-, muskotályzsálya olaj), ezeknél a koncentrációfüggés jól követhető volt. Kifejezetten hatékonynak bizonyult a fahéj illóolaj a kísérletek folyamán, főképpen a Fusarium izolátumok gátlásánál. Már kis mennyiségben történő alkalmazásával is $\left(0,105 \mathrm{mg} / \mathrm{cm}^{3}\right)$ teljes növekedésgátlást értünk el hat vizsgált izolátumnál ( $F$. graminearum, $F$. culmorum, $F$. verticillioides, $A$. westerdijkiae, $A$. longivesica, C. hawaiensis). A majoránna és muskotályzsálya illóolajok különösen nagy koncentrációban történő alkalmazásuk esetén $\left(0,42 \mathrm{mg} / \mathrm{cm}^{3}\right)$ bizonyultak hatékonynak a tíz vizsgált izolátum növekedésgátlásában. 
A

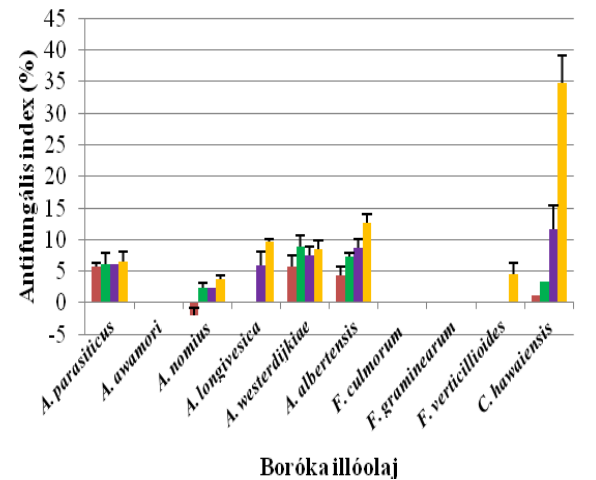

$\mathrm{C}$

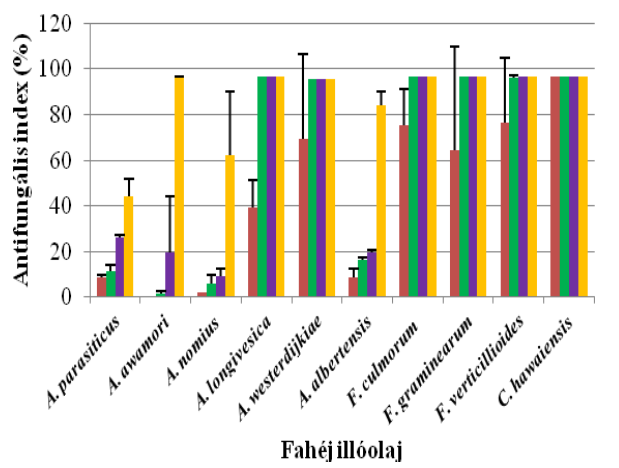

B

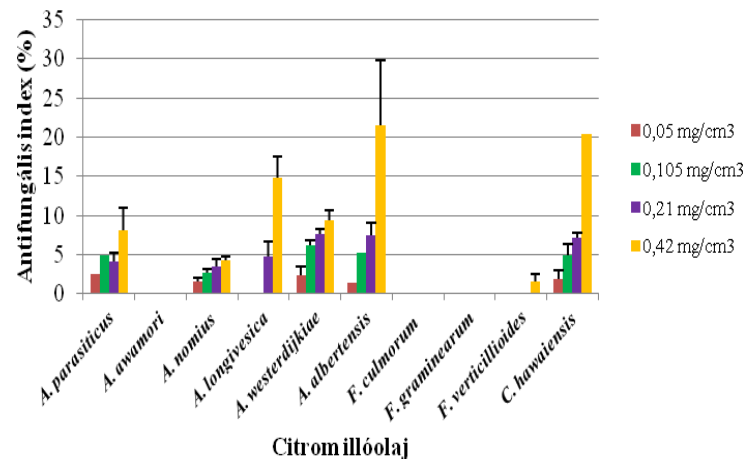

D

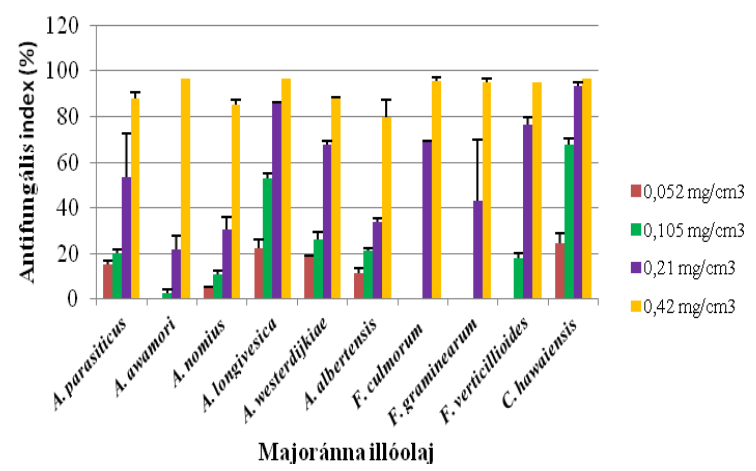

E

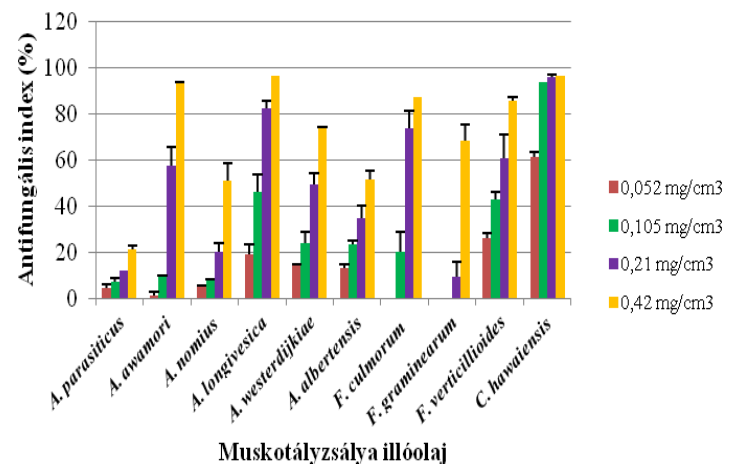

22. ábra: Antifungális indexek (\%) alakulása a tesztelt fonalasgombáknál illóolaj gőztérben. A: boróka illóolaj, B: citrom illóolaj, $\mathrm{C}$ : fahéj illóolaj, D: majoránna illóolaj, E: muskotályzsálya illóolaj.

\subsection{Illóolajok hatása az $A$.parasiticus és az A.nomius aflatoxin termelésére}

A kísérletekbe bevont illóolajok $A$. parasiticus és $A$. nomius izolátumok aflatoxin termelésére gyakorolt hatását vizsgáltuk szilárd táptalajon és folyadéktenyészetben végzett kísérletek által. 


\subsubsection{Szilárd táptalajon tenyésztett A. parasiticus aflatoxin termelése}

Az A. parasiticus Petri-csészékre leoltott, illóolaj tartalmú gőztérben 10 napig inkubált telepeit vontuk vizsgálat alá. A telepeket tartalmazó szilárd tápközeget felaprítottuk, diklórmetán segítségével extrakciót hajtottunk végre, majd HPLC-vel mértük meg a minták aflatoxin tartalmát. Mivel a telepek növekedését az inkubációs periódus alatt mértük, az aflatoxin tartalmat telepterületre vonatkoztattuk $\left(\mu \mathrm{g} / \mathrm{mm}^{2}\right)$.

5.5.1.1. Az A. parasiticus konídiumképzésének és morfológiai karakterisztikájának meghatározása

Kísérleteink során meghatároztuk az A. parasiticus spóraszámát, és vizsgáltuk a morfológiai változásokat a légtér 0,21 és $0,42 \mathrm{mg} / \mathrm{cm}^{3}$ illóolaj koncentrációjánál (9. táblázat, 26. ábra). A kontroll minták átlag konídium száma $\lg 7,65 / \mathrm{ml}$ volt. A citrom és a muskotályzsálya illóolaj esetén $0,21 \mathrm{mg} / \mathrm{cm}^{3}$ koncentrációnál a spóraképződés szignifikáns csökkenése mutatkozott $(\mathrm{P}<0,05)$. Az illóolajok magasabb koncentrációjánál valamennyi vizsgált esetben szignifikánsan csökkent a konídiumok száma (40-80\% csökkenés).

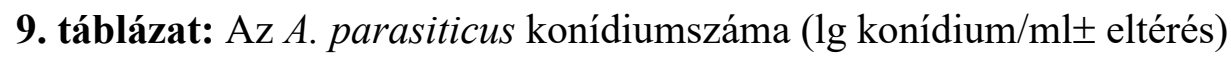

\begin{tabular}{ccc}
\hline Kontroll & \multicolumn{2}{c}{$7,65 \pm 0,031$} \\
\hline Illóolaj & Légtérfogatra vonatkoztatott illóolaj koncentráció $\left(\mathrm{mg} / \mathrm{cm}^{3}\right)$ \\
\hline Borókaolaj & 0,21 & 0,42 \\
Citromolaj & $7,44 \pm 0,019$ & $7,39 \pm 0,025^{*}$ \\
Fahéjolaj & $7,29 \pm 0,070^{*}$ & $7,41 \pm 0,016^{*}$ \\
Majoránnaolaj & $7,36 \pm 0,014$ & $5,93 \pm 0,008^{*}$ \\
Muskotályzsálya & $6,75 \pm 0,110$ & $\mathrm{NK}$ \\
olaj & $7,19 \pm 0,000^{*}$ & $6,18 \pm 0,021^{*}$ \\
*: a szignifikáns eltérés a kontrollhoz képest, páros t-próba alkalmazásával $(\mathrm{P}<0,05)$
\end{tabular}

NK: nem volt konídiumképzés

Majoránna illóolajat tartalmazó gőztér esetén $0,42 \mathrm{mg} / \mathrm{cm}^{3}$ illóolaj koncentrációnál a telepek nem mutattak spóraképzést. A fénymikroszkópos felvételeken konídiumok nélküli, torzult konídiofórok és károsodott hifák láthatók (23. ábra). 


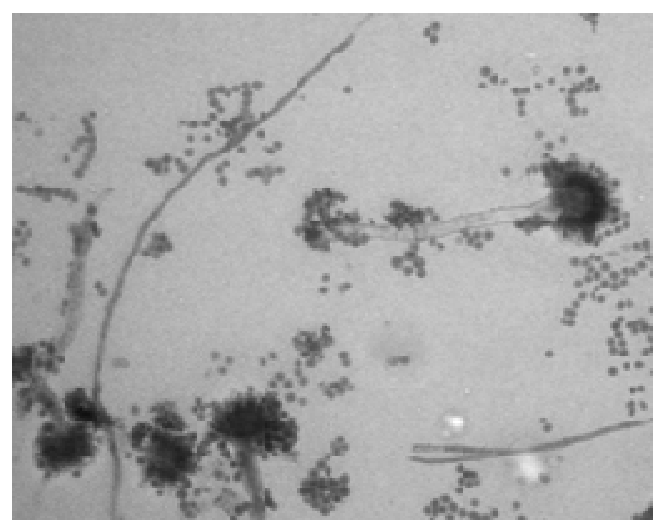

A

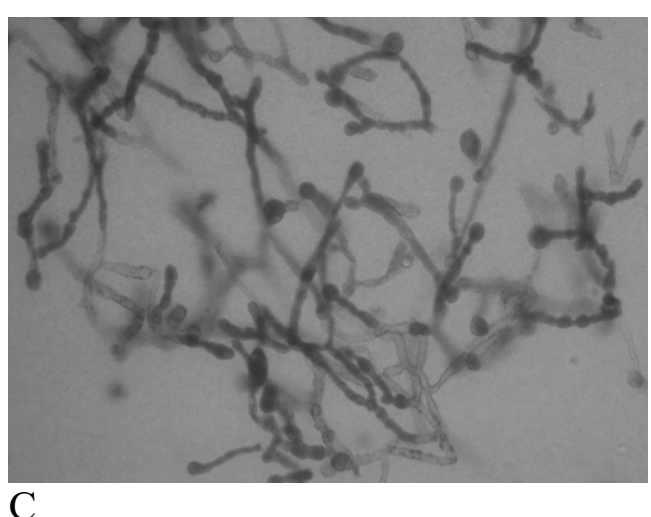

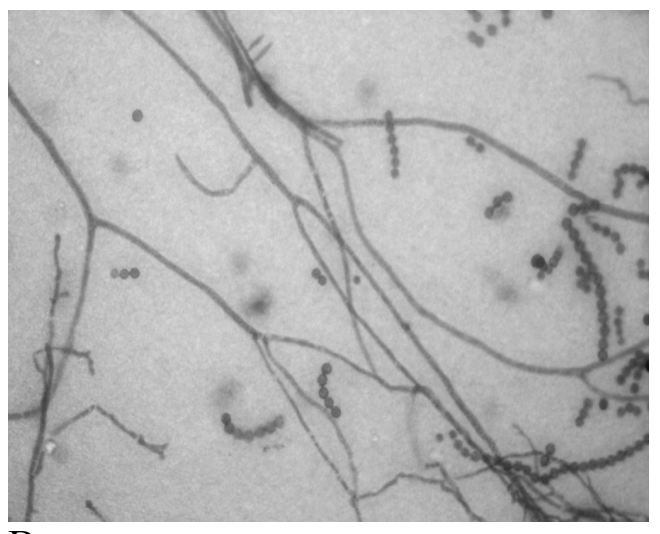

$\mathrm{B}$

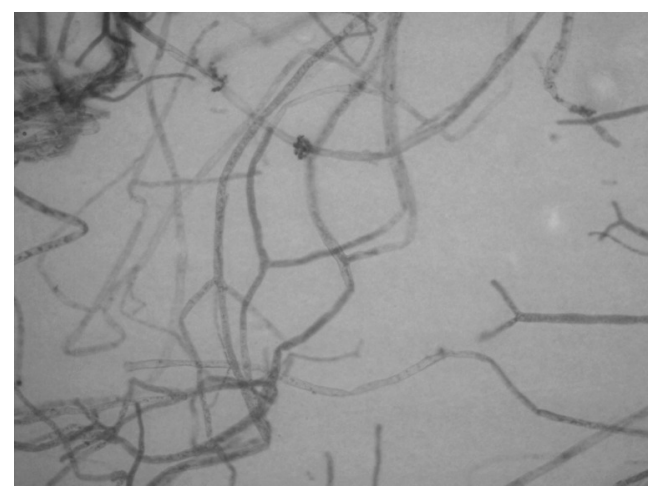

$\mathrm{D}$

23. ábra: Fénymikroszkópos felvételek az A. parasiticus illóolaj gőzteres kezelését követően. A: kontroll minta; B: $0,21 \mathrm{mg} / \mathrm{cm}^{3}$ majoránna illóolaj, C: $0,42 \mathrm{mg} / \mathrm{cm}^{3}$ majoránna illóolaj, D: $0,42 \mathrm{mg} / \mathrm{cm}^{3}$ muskotályzsálya illóolaj alkalmazásával (nagyítás: 200-szoros) 
5.5.1.2. Illóolajok hatása az A. parasiticus mikotoxin termelésére

A telepterületre vonatkoztatott eredményeket a 10. táblázat tartalmazza.

10. táblázat: Illóolajok hatása az A. parasiticus aflatoxin termelésére.

\begin{tabular}{lcc}
\hline Illóolaj & $\begin{array}{c}\text { Illóolaj koncentráció } \\
\left(\mathrm{mg} / \mathrm{cm}^{3}\right)\end{array}$ & $\begin{array}{c}\text { Aflatoxinok } \\
\left(\mu \mathrm{g} / \mathrm{mm}^{2}\right)\end{array}$ \\
\hline Kontroll & 0,00 & $0,353 \pm 0,059 \mathrm{a} *$ \\
\hline Boróka & 0,052 & $0,433 \pm 0,023 \mathrm{a}$ \\
& 0,105 & $0,369 \pm 0,064 \mathrm{a}$ \\
& 0,21 & $0,379 \pm 0,115 \mathrm{a}$ \\
Citrom & 0,42 & $0,440 \pm 0,084 \mathrm{a}$ \\
& 0,052 & $0,483 \pm 0,088 \mathrm{a}$ \\
& 0,105 & $1,064 \pm 0,606 \mathrm{~b}$ \\
Fahéj & 0,21 & $0,424 \pm 0,027 \mathrm{a}$ \\
& 0,42 & $0,577 \pm 0,070 \mathrm{a}$ \\
& 0,052 & $0,617 \pm 0,121 \mathrm{ab}$ \\
& 0,105 & $1,270 \pm 0,559 \mathrm{~b}$ \\
& 0,21 & $1,027 \pm 0,338 \mathrm{ab}$ \\
Majoránna & 0,42 & $0,308 \pm 0,008 \mathrm{a}$ \\
& 0,052 & $0,403 \pm 0,065 \mathrm{a}$ \\
& 0,105 & $0,427 \pm 0,193 \mathrm{a}$ \\
& 0,21 & $0,433 \pm 0,030 \mathrm{a}$ \\
& 0,42 & $0,013 \pm 0,005 \mathrm{~b}$ \\
\hline Muskotályzsálya & 0,052 & $0,342 \pm 0,107 \mathrm{a}$ \\
& 0,105 & $0,374 \pm 0,096 \mathrm{a}$ \\
& 0,21 & $0,352 \pm 0,078 \mathrm{a}$ \\
& 0,42 & $0,321 \pm 0,032 \mathrm{a}$ \\
\hline
\end{tabular}

* A különböző betűk szignifikáns eltérést $(\mathrm{P}<0,05)$ jeleznek, míg azonos betük esetében az eltérés nem volt szignifikáns az eredmények között.

Az illóolaj koncentráció növekedése csaknem minden esetben az összes aflatoxin megnövekedett mennyiségét eredményezte (24. ábra). A fahéj illóolaj $\left(0,105 \mathrm{mg} / \mathrm{cm}^{3}\right.$ és 0,21 $\left.\mathrm{mg} / \mathrm{cm}^{3}\right)$ és a citrom illóolaj $\left(0,105 \mathrm{mg} / \mathrm{cm}^{3}\right)$ alkalmazása esetén az aflatoxin termelés szignifikánsan növekedett a kontrollhoz képest $(\mathrm{P}<0,001)$. A többi esetben a növekedés azonban nem volt szignifikáns $(\mathrm{P}>0,05)$. 
A

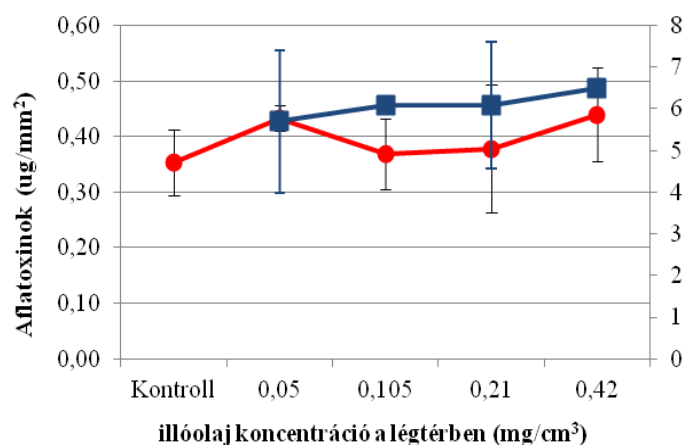

$\mathrm{C}$

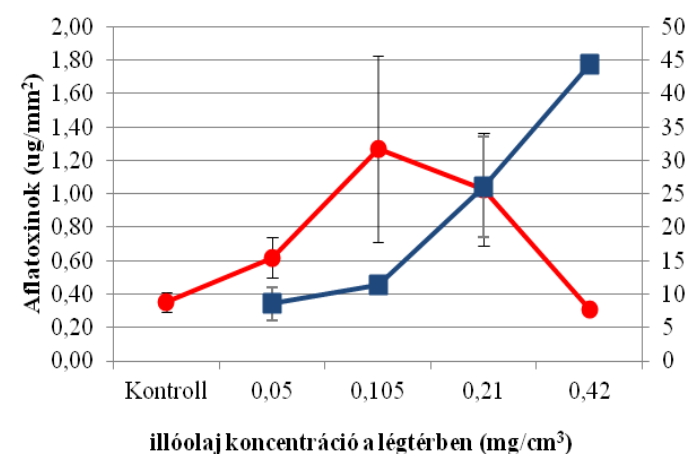

B

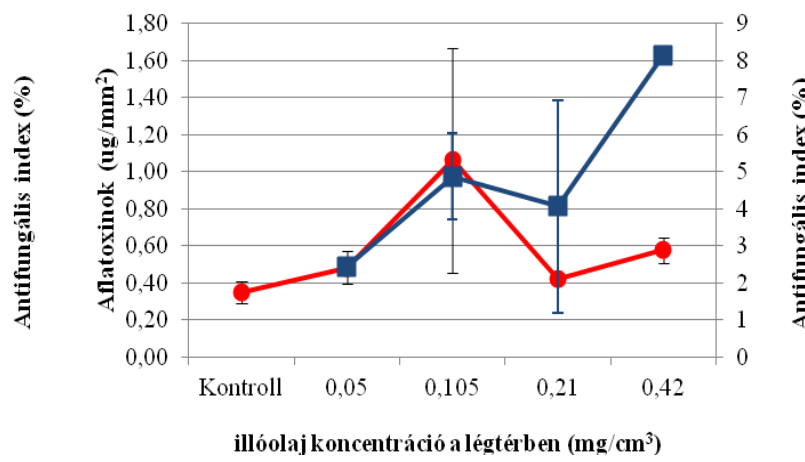

D

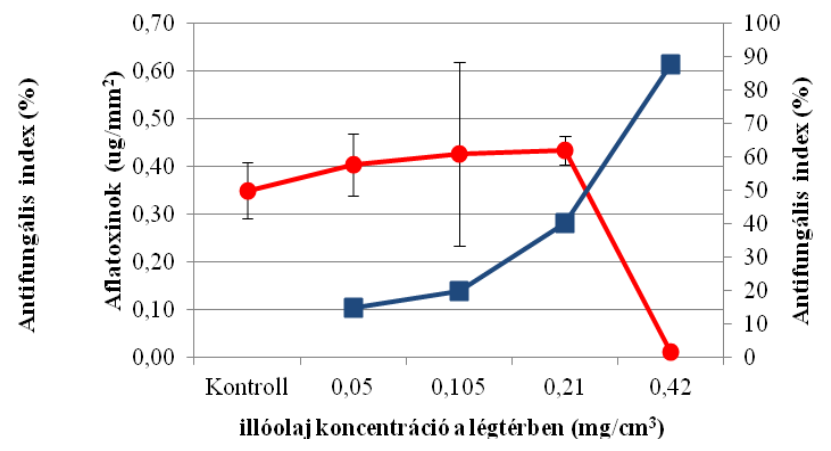

E

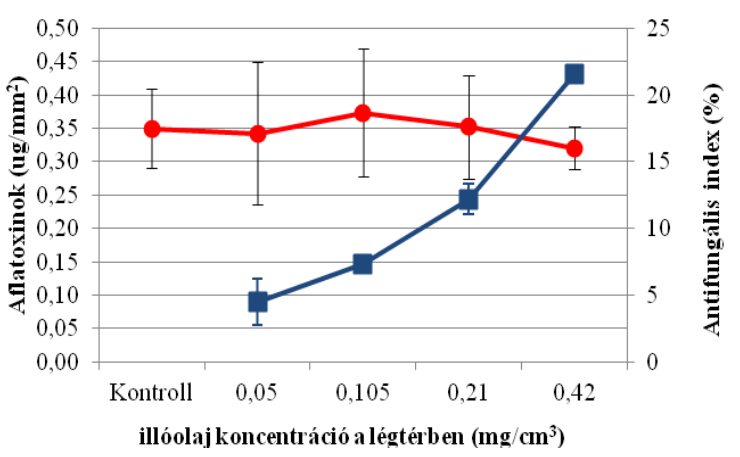

24. ábra: Boróka (A), citrom (B), fahéj (C), majoránna (D) és muskotályzsálya (E) illóolajok hatása az $A$. parasiticus aflatoxin termelésére és az antifungális indexek alakulására. Az Y tengelyek adatai mutatják az összes aflatoxin mennyiséget $\left(\mu \mathrm{g} / \mathrm{mm}^{2}\right)$ (piros vonal) és az antifungális indexeket (\%) (kék vonal). Az egyes értékekhez tartozó szórásokat is feltüntettük.

Az A. parasiticus a termelt aflatoxinfélék összetételének szokatlan mintáját mutatta. A kezeletlen és a kezelt minták többségében az AFG1 volt jelen a legnagyobb, az AFB2 pedig a legkisebb mennyiségben (25. ábra). Ugyanakkor $0,42 \mathrm{mg} / \mathrm{cm}^{3}$ koncentrációjú majoránna és fahéj illóolaj alkalmazásánál az AFB1 aránya növekedett, az AFG1 aránya pedig csökkent. 
A
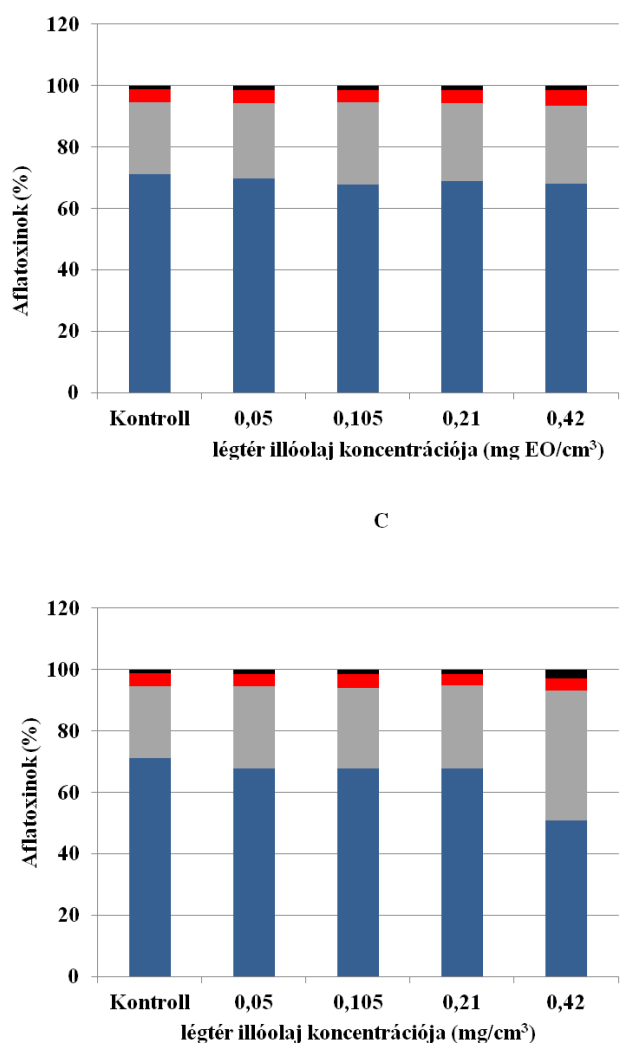

B
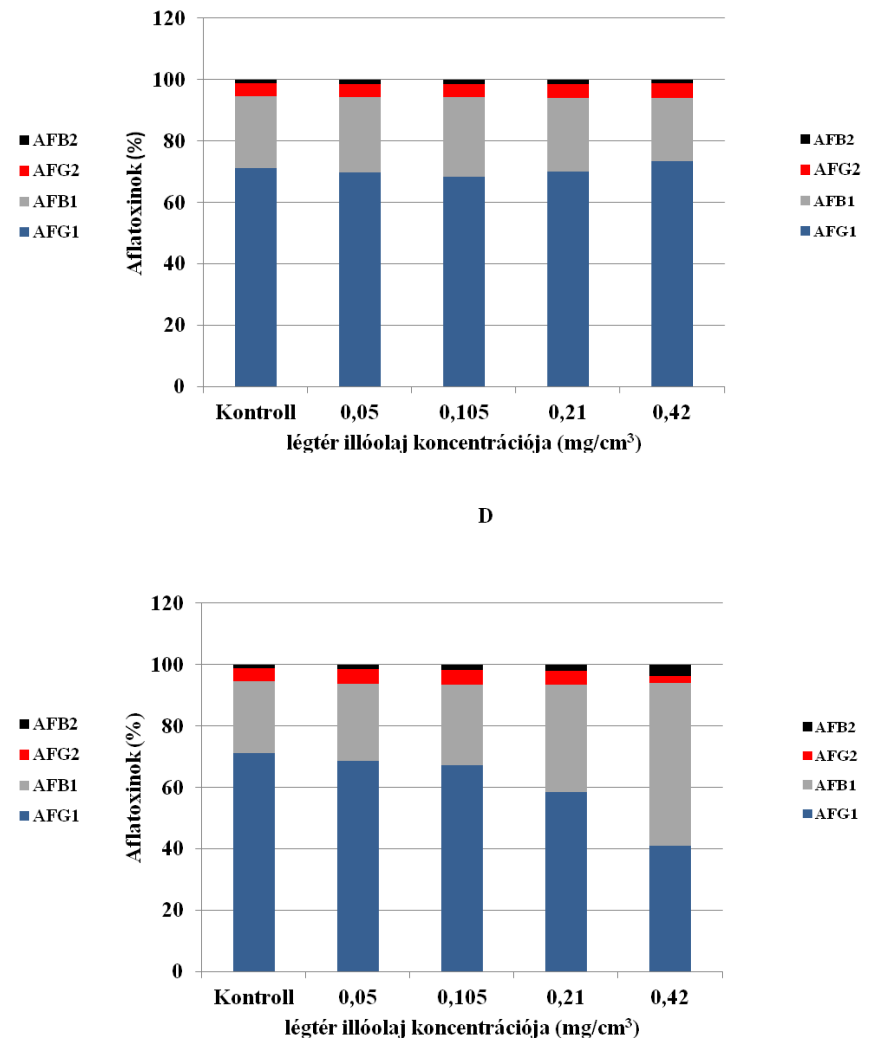

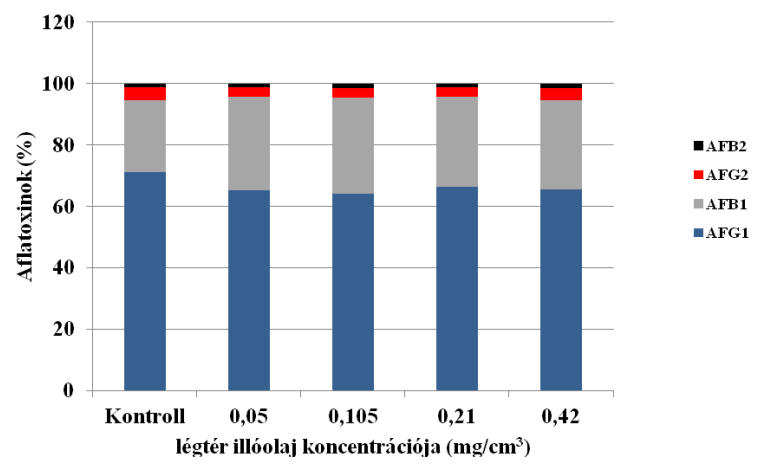

25. ábra: Boróka $(\mathrm{A})$, citrom $(\mathrm{B})$, fahéj $(\mathrm{C})$, majoránna $(\mathrm{D})$ és muskotályzsálya $(\mathrm{E})$ illóolaj gőztér hatása az $A$. parasiticus által termelt aflatoxin típusok \%-os arányára.

A kapott eredményeket elemezve, összességében megállapíthatjuk, hogy az $A$. parasiticus-nál a majoránna illóolaj az alkalmazott legmagasabb koncentrációban (0,42 $\mathrm{mg} / \mathrm{cm}^{3}$ ) mutatta a leghatékonyabb gátlást mind a növekedés, mind pedig a toxintermelés vonatkozásában. Ez magas antifungális indexet és alacsony aflatoxin-termelést eredményezett. 
Kísérleteink során a fahéj és a muskotályzsálya illóolajok esetében nem tapasztaltuk az aflatoxin termelés szignifikáns gátlását, azonban megfigyeltük a konídiumok számának több, mint 1 nagyságrenddel történő csökkenését. Eredményeink azt is mutatják, hogy mind az illóolajok kémiai jellege (ami az összetevők függvénye), mind az alkalmazott koncentráció fontos tényezők az aflatoxin szintézis gátlásában.

Kísérleteink során a kapott eredmények arra mutatnak rá, hogy az illóolajok stresszfaktorként lehetnek jelen, ezáltal növelhetik az A. parasiticus aflatoxin termelését, különösen alacsony koncentrációknál (27. ábra). A gyenge antifungális hatással rendelkező olajoknál (boróka és citrom illóolajok) mind az antifungális index, mind az aflatoxin termelés növekedést mutatott. Ezzel szemben a jobb antifungális tulajdonságokkal bíró illóolajok esetén, kis koncentrációknál, a toxintermelés növekedett alacsony vagy közepes antifungális hatással társulva. A toxintermelés akkor kezdett csak csökkenni, amikor a növekedésgátlás elért egy bizonyos mértéket (30-40\% gátlás a fahéjolajnál és a majoránnaolajnál, valamint $12 \%$ a muskotályzsálya olajnál). A legmagasabb illóolaj koncentrációnál $\left(0,42 \mathrm{mg} / \mathrm{cm}^{3}\right)$ általában csökkent a gombatelep mérete. Ebben az esetben várható volt az aflatoxin termelés és a spóraképződés csökkenése. A mikotoxin termelés szignifikáns gátlását azonban csak a majoránna illóolaj esetében tudtuk kimutatni, itt a növekedés csaknem teljes gátlást szenvedett. (Gömöri 2018b). Az általunk alkalmazott illóolajok fő komponensként föként terpéneket tartalmaznak lehetséges pro-oxidáns hatásokkal, így nem zárható ki, hogy részben az oxidatív stressz okozta az illóolajok alkalmazása során a megnövekedett aflatoxin termelést.

Eredményeink vonatkozásában felmerül, hogy csak azok az illóolajok voltak képesek csökkenteni az A. parasiticus aflatoxin termelését, amelyek erös antifungális hatással bírnak. Ennek megfelelően az illóolajok használatának legjobb módja a megfelelően magas koncentrációban történő alkalmazás, annak érdekében, hogy az aflatoxin termelést és a fonalasgomba növekedését is szignifikánsan csökkentsék.

5.5.2. A.parasiticus és A.nomius izolátumok tenyésztése folyadékban, az aflatoxin termelés kinetikájának vizsgálata

A 10 rendelkezésünkre álló izolátum közül az aflatoxin termelésre vonatkozó kísérleteket $A$. parasiticus és $A$. nomius törzsekkel végeztük el, mivel eddigi ismereteink szerint ezek jó termelők. A fonalasgomba telepek változó koncentrációjú, illóolajat tartalmazó 
gőztérben, táplevesben, 15 napig növekedtek. Az extrahálást követően az idő függvényében detektáltuk a termelt aflatoxinok mennyiségét és arányát. Mindkét izolátum aflatoxin termelését a fermentációs térfogatra és a száraz micélium tömegre is kiszámoltuk, hogy lássuk az összefüggést a növekedés és a termelés között. Amennyiben a két érték nem mutatott lényeges különbséget, a száraztömegre vonatkoztatott adatokat ábrázoltuk. A szórásokat az aflatoxin termelés és a micéliumok száraztömeg változását együttesen bemutató diagramokon ábrázoltuk. A micéliumtömegre vonatkoztatott aflatoxint bemutató diagramok esetében, azok átláthatósága, értelmezhetősége miatt - a szórások ábrázolásától eltekintettünk.

\subsubsection{A. nomius aflatoxin termelése}

\subsection{Kezelés boróka illóolajjal}

Az aflatoxin termelés kinetikájának bemutatásához a termelt aflatoxinok mennyiségét a micéliumok száraz tömegére vonatkoztattuk (26. ábra).

A kezelt telepek, a kontroll telepekhez hasonlóan, a legtöbb aflatoxint az inkubáció 12 . napján termelték . Az illóolajos kezelés hatására az inkubáció kezdeti szakaszában (harmadik napig) nem volt többlettermelés kimutatható a kontroll mintákhoz képest (27. ábra).

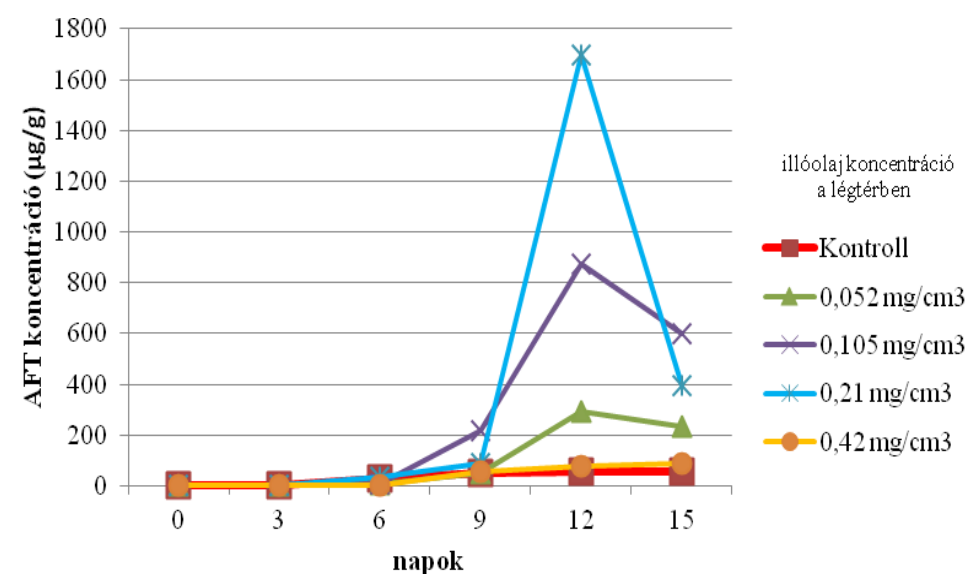

26. ábra: $\mathrm{Az}$ A. nomius által termelt, micéliumtömegre vonatkoztatott összes aflatoxin $(\mu \mathrm{g} / \mathrm{g})$ időbeli változása boróka illóolaj gőztérben.

A tizenkettedik napra az illóolajjal kezelt minták mindegyikében megnövekedett aflatoxin szintet mutattunk ki, ami több ezerszerese volt a kontroll értéknek. Egyedül a legmagasabb illóolaj koncentrációnál maradt az aflatoxin szint a kontroll érték közelében. Az illóolaj alkalmazása tehát serkentőleg hatott a toxinképzésre. 
A

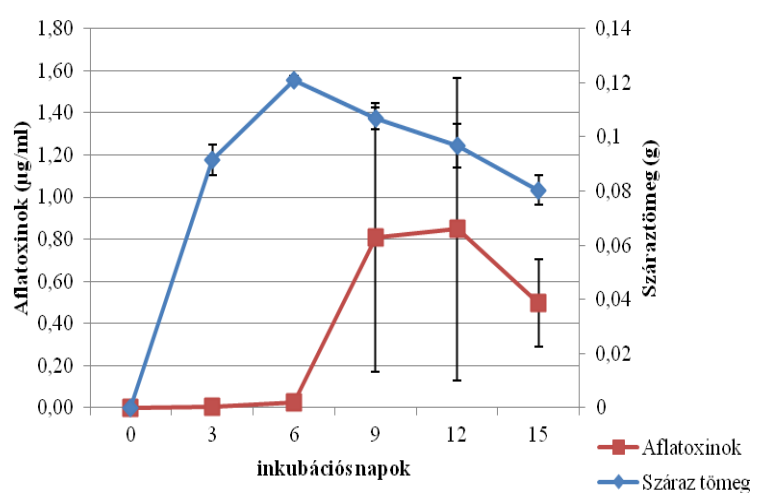

B
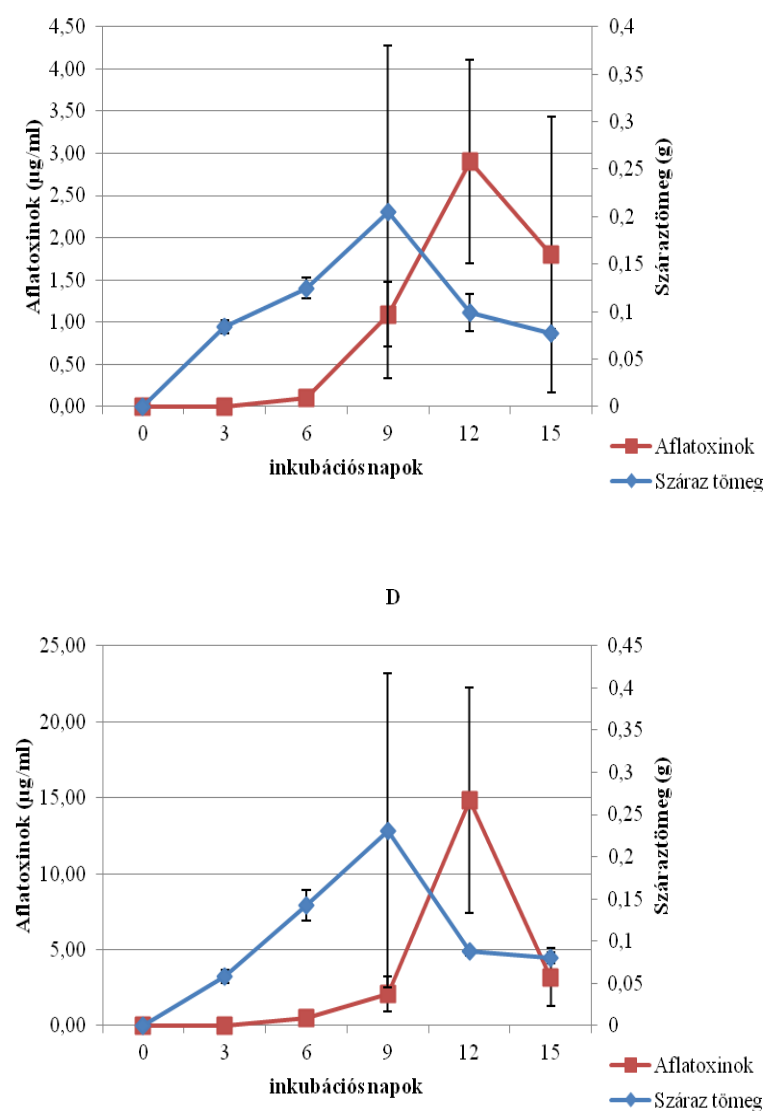

$\mathrm{C}$

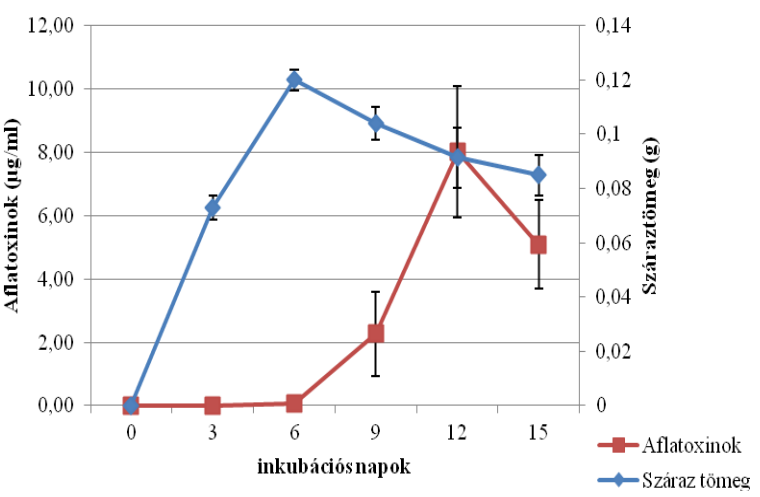

E

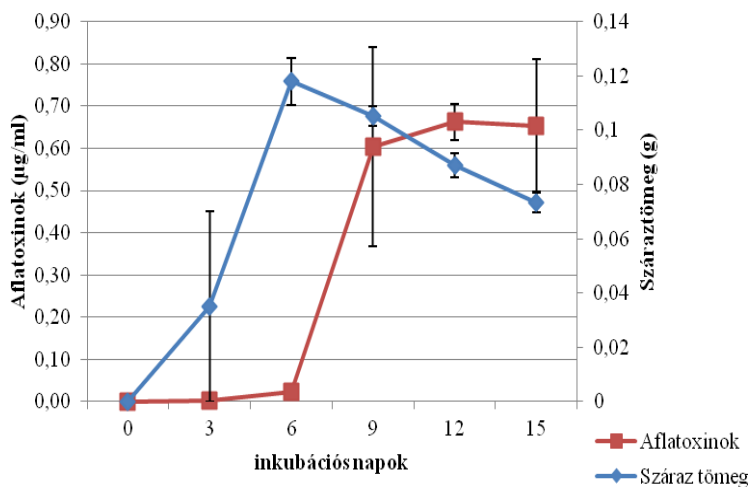

27. ábra: A. nomius által termelt aflatoxinok $(\mu \mathrm{g} / \mathrm{ml})$ valamint a telepek száraztömegének (g) időbeni változása boróka illóolajos kezelést követően. Alkalmazott boróka illóolaj koncentrációk a légtérben: A: kontroll minták, B: $0,05 \mathrm{mg} / \mathrm{cm}^{3}, \mathrm{C}: 0,105 \mathrm{mg} / \mathrm{cm}^{3}, \mathrm{D}: 0,21$ $\mathrm{mg} / \mathrm{cm}^{3}, \mathrm{E}: 0,42 \mathrm{mg} / \mathrm{cm}^{3}$

A micéliumok száraz tömege az inkubációs idő előre haladtával hasonló tendenciát mutatott, mint az aflatoxin termelés kinetikája. A micéliumok száraz tömege általában a 6 . vagy a 9. napokon érte el maximumát, majd csökkent (27. ábra). Mind a száraztömeg 
csökkenés (autolízis), mind pedig a boróka illóolaj hatására bekövetkező, megnövekedett aflatoxin termelés a fonalasgomba stressz-válaszának tulajdonítható.

Jaimez és munkatársai (2000) kísérleteik eredményeképpen leírták, hogy toxicitás tekintetében a különböző aflatoxin variációknál a következő sorrend állítható fel: AFB1 > AFG1 $>$ AFB2 $>$ AFG2.

Jelen kísérletünkben a termelt aflatoxinok arányát tekintve mind a kontroll mintáknál, mind a boróka illóolajjal kezelt mintáknál az AFG1 (átlagosan 80\%), illetve az AFB1 (átlagosan 20-30\% között) termelödött a legnagyobb arányban (28. ábra). A hosszabb inkubációs idő és a növekvő illóolaj koncentráció az arányokat némileg módosította a kontroll mintákhoz képest: csökkent a jelen lévő AFG1 és növekedett - a legnagyobb toxicitással bíró - AFB1 aránya.

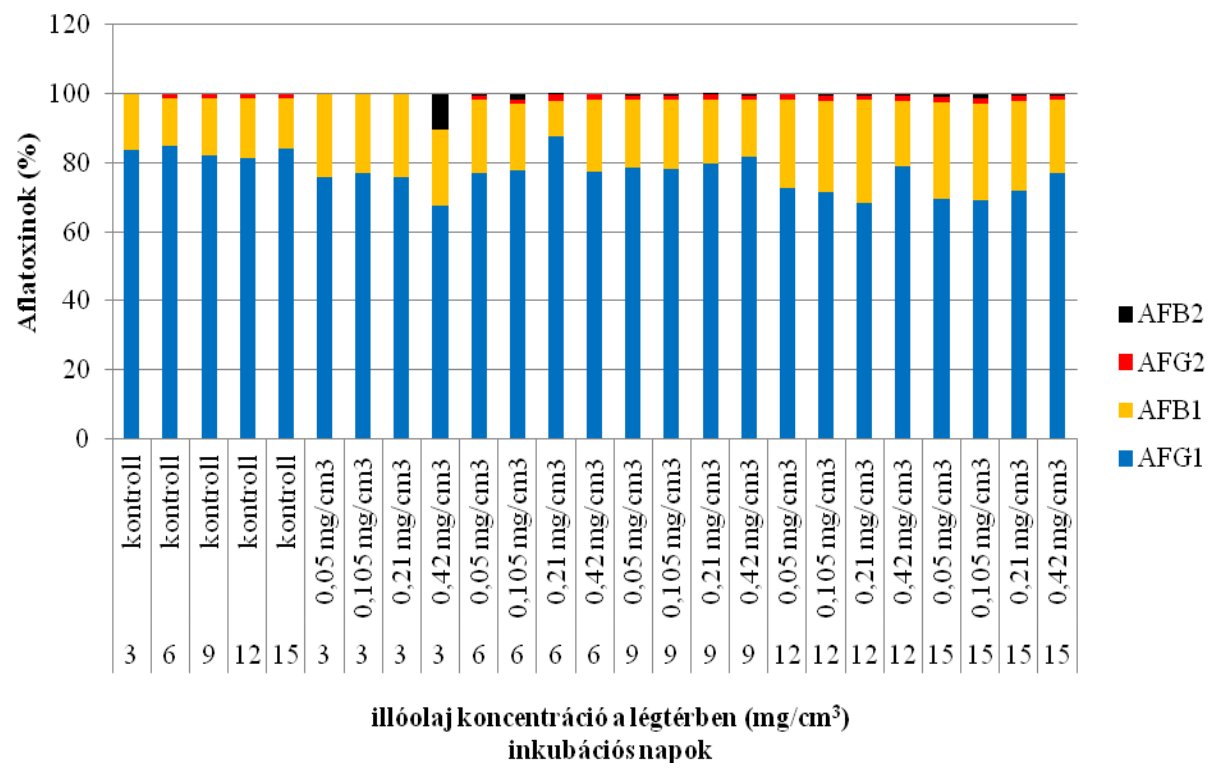

28. ábra: A. nomius által termelt aflatoxinok aránya (\%) különböző koncentrációkban alkalmazott boróka illóolajos kezelést követően, az inkubációs idő figyelembe vételével.

\subsection{Kezelés citrom illóolajjal}

Kísérleteink során a citrom illóolaj a boróka olajhoz hasonló hatást mutatott. Az illóolajjal kezelt mintákban általában a 9., a kontroll mintákban pedig a 12. inkubációs napon mértük a maximális aflatoxin mennyiséget.

A citrom illóolaj minden esetben több ezerszeresére növelte a termelt aflatoxin mennyiségét (29. ábra). 


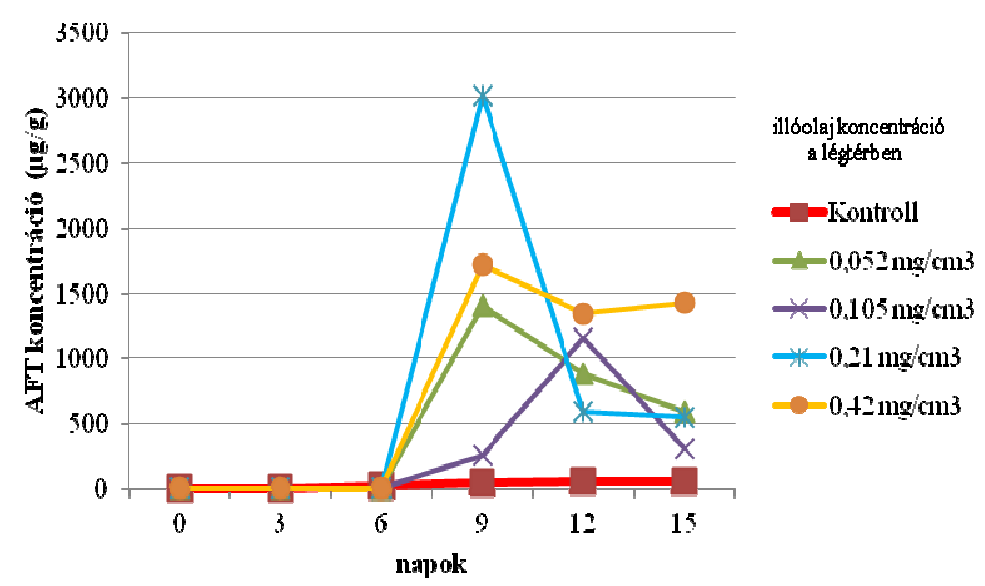

29. ábra: $\mathrm{Az}$ A. nomius által termelt, micéliumtömegre vonatkoztatott összes aflatoxin $(\mu \mathrm{g} / \mathrm{g})$ időbeli változása citrom illóolaj gőztérben.

A száraztömeg csökkenése jellemzően az inkubáció 6. illetve 9. napjától indult el (30. ábra). Az adatok elemzésekor megállapítottuk, hogy a légtér növekvő illóolaj koncentrációja időben késleltette a száraztömeg csökkenésének bekövetkezését. 


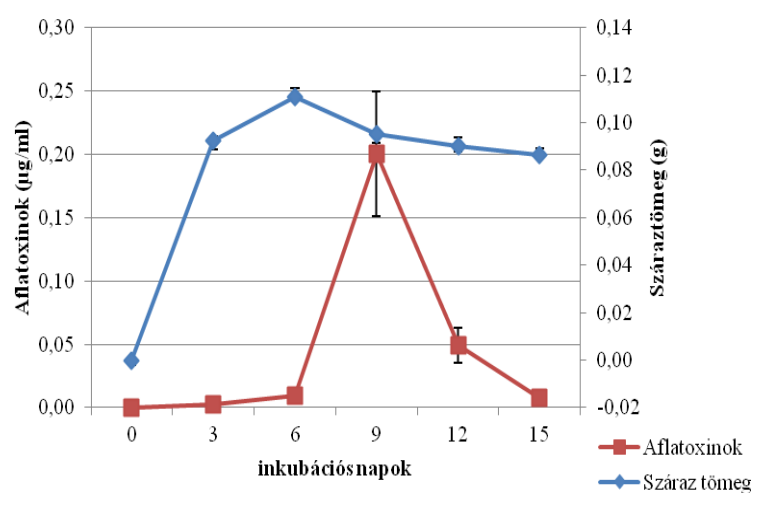

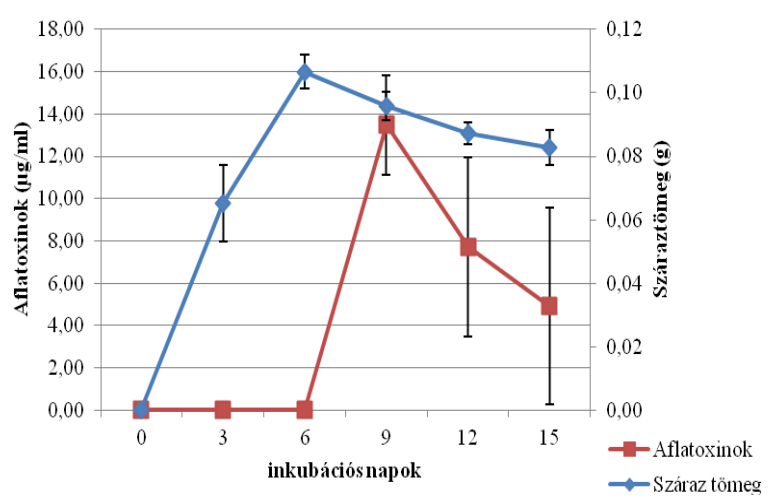

D

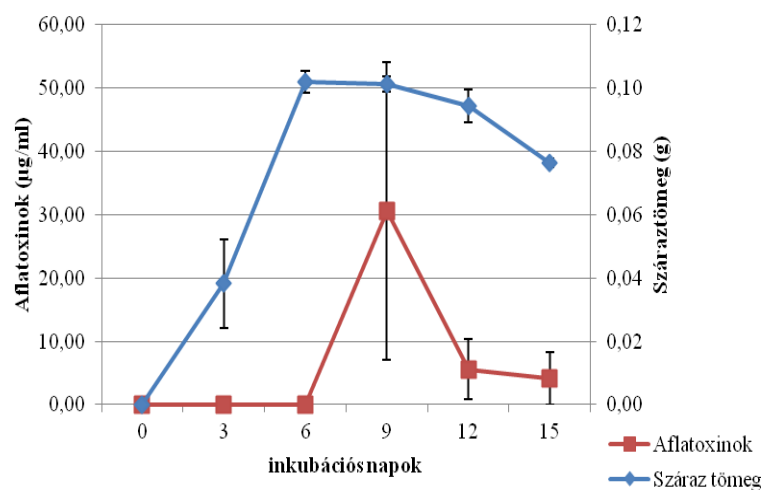

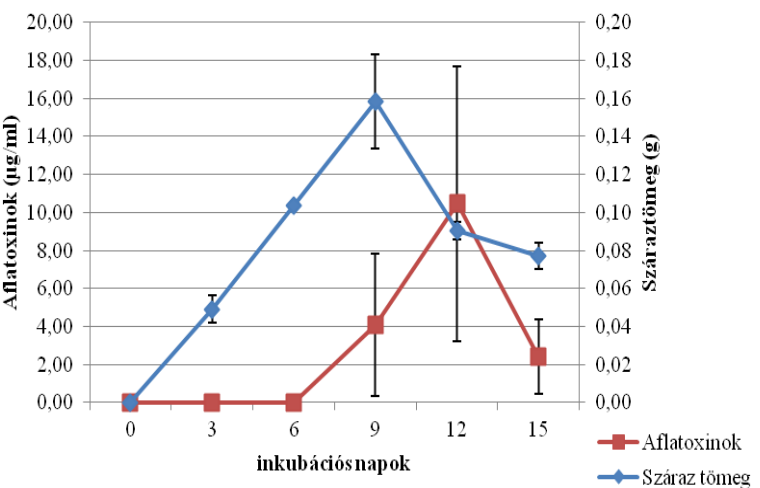

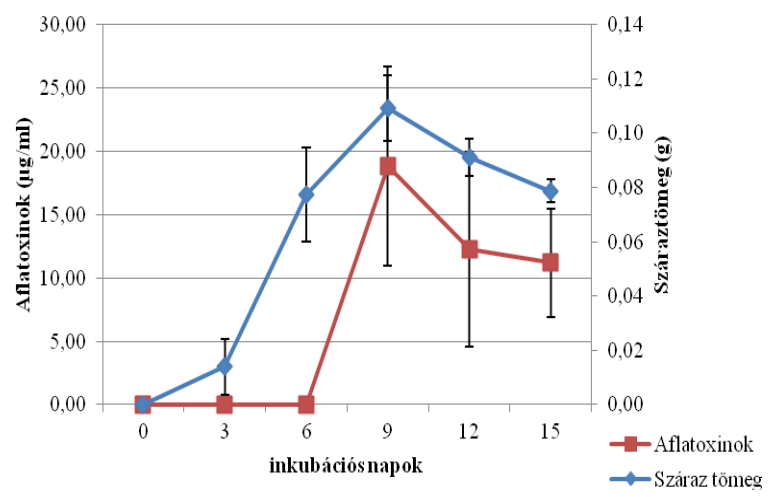

30. ábra: A. nomius által termelt aflatoxinok $(\mu \mathrm{g} / \mathrm{ml})$ valamint a telepek száraztömegének (g) időbeni változása citrom illóolajos kezelést követően. Alkalmazott citrom illóolaj koncentrációk a légtérben: A: kontroll minták, B: $0,05 \mathrm{mg} / \mathrm{cm}^{3}, \mathrm{C}: 0,105 \mathrm{mg} / \mathrm{cm}^{3}, \mathrm{D}: 0,21$ $\mathrm{mg} / \mathrm{cm}^{3}, \mathrm{E}: 0,42 \mathrm{mg} / \mathrm{cm}^{3}$

A termelt aflatoxinok arányát tekintve, döntő többségben AFG1 termelés jellemezte az A. nomius-t. Az alkalmazott citrom illóolaj koncentrációjának növelése csökkentette az AFG1 és növelte az AFB1 arányát. AFB2 jellemzően a 6. napig termelödött nagyobb arányban, az AFG2 pedig a 6. napot követően (31. ábra). 


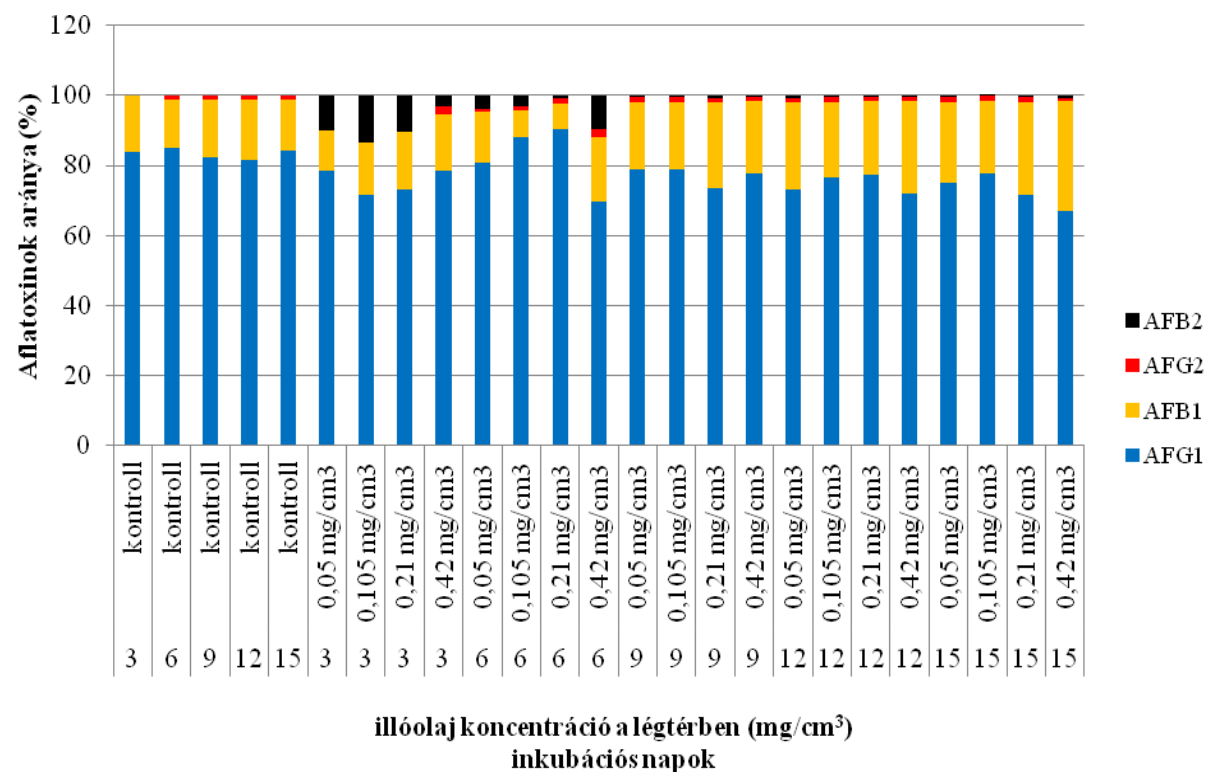

31. ábra: A. nomius által termelt aflatoxinok aránya (\%) a légtérben különböző koncentrációkban alkalmazott, citrom illóolajos kezelést követően, az inkubációs idő figyelembe vételével.

\subsection{Kezelés fahéj illóolajjal}

Szilárd táptalajon, a fahéj illóolaj az A. nomius-izolátumnál a telepek növekedési sebességének csökkentésében és a telepnövekedés gátlásában is hatékonyabbnak bizonyult, mint a boróka vagy a citrom illóolaj. Folyadéktenyészetben, az aflatoxin termelés kinetikáját vizsgálva megállapítható, hogy a fahéj illóolaj a légtérben az inkubáció 9. napjától kezdődően igen jelentősen növelte az $A$. nomius aflatoxin termelését (32. ábra) $0,052 \mathrm{mg} / \mathrm{cm}^{3}$ koncentrációban alkalmazva. Ennél nagyobb koncentrációkban alkalmazva az idő elörehaladtával a toxin szint nőtt ugyan, de alacsonyabb volt, mint a kezeletlen mintákban.

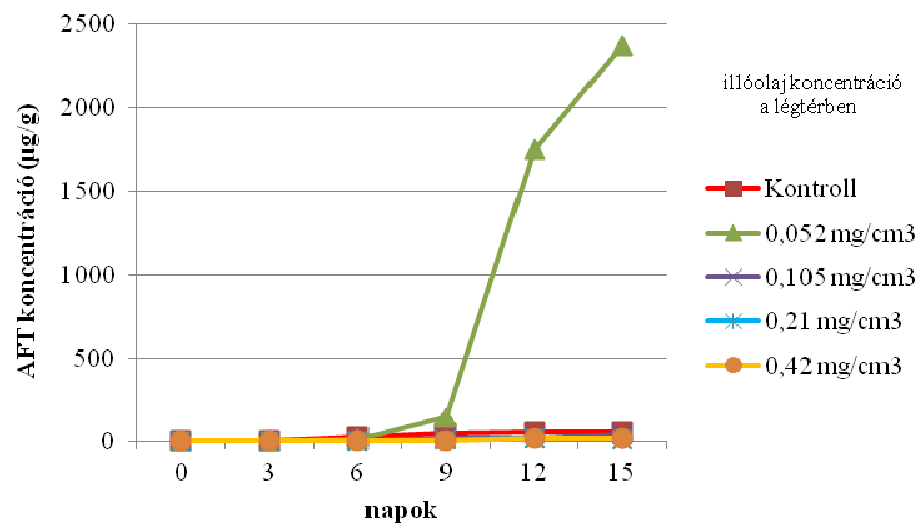

32. ábra: Az A. nomius által termelt, micéliumtömegre vonatkoztatott összes aflatoxin $(\mu \mathrm{g} / \mathrm{g})$ időbeli változása fahéj illóolaj gőztérben. 
A fahéj illóolajjal végzett kísérleteknél a micéliumtömeg a 6. napon érte el a maximumát mind a kezelt mintáknál, mind a kontroll esetén, majd ezt követően csökkent (33. ábra). A kontrollnál, valamint a fahéj illóolaj magasabb koncentrációban történő alkalmazása esetében $\left(0,21 \mathrm{mg} / \mathrm{cm}^{3}, 0,42 \mathrm{mg} / \mathrm{cm}^{3}\right)$ a micéliumtömeg csökkenése időben nem járt együtt a termelt aflatoxin mennyiség csökkenésével.

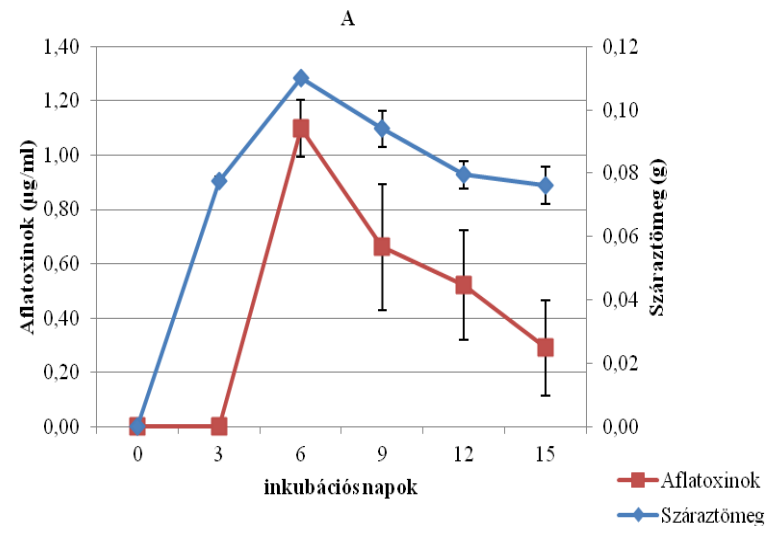

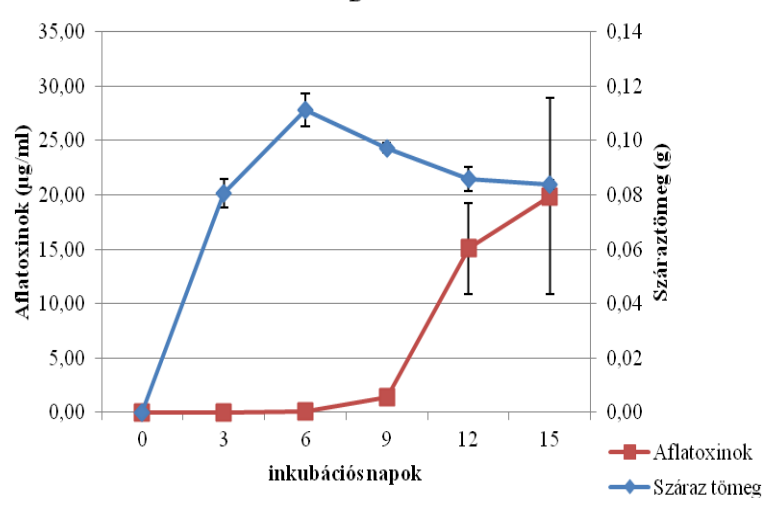

D

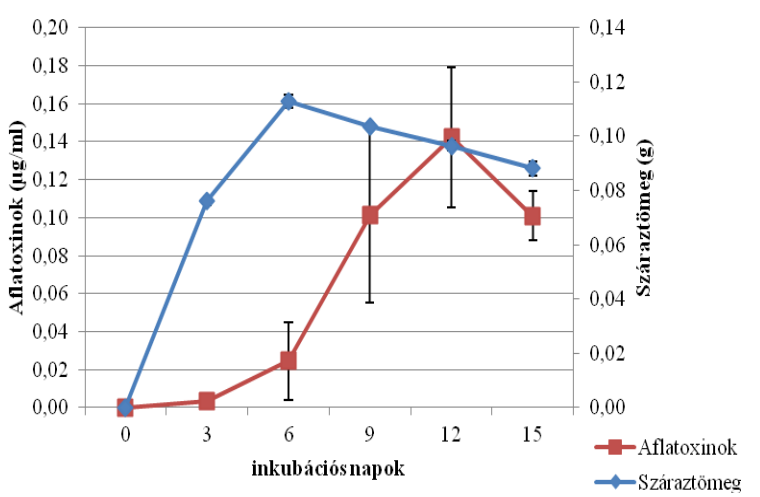

$\mathrm{C}$

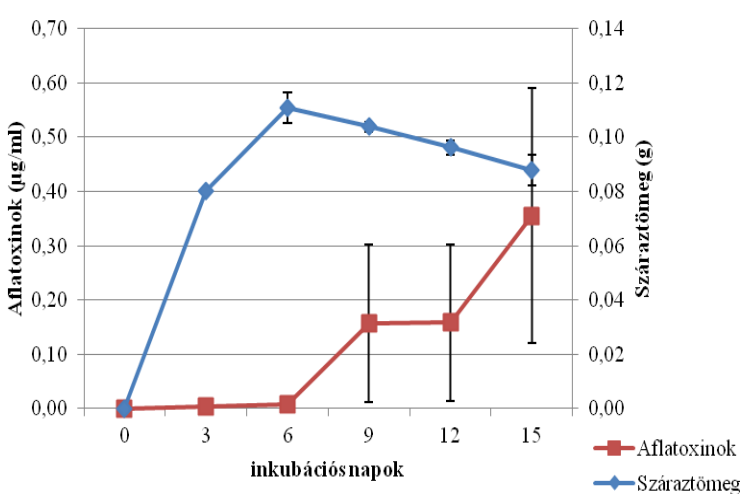

E

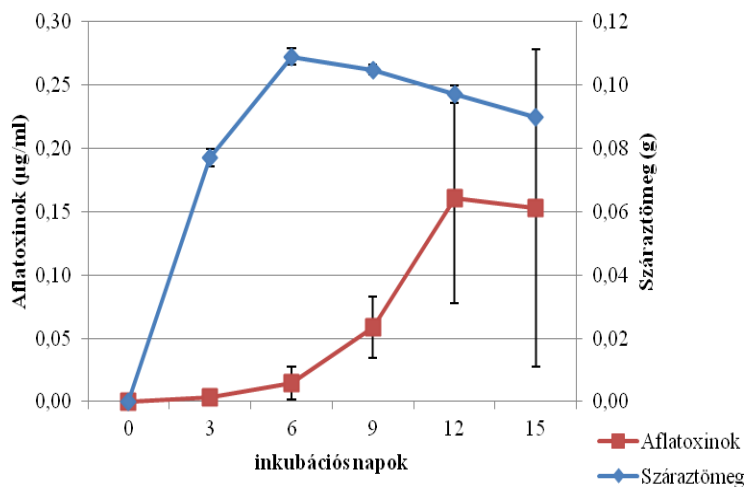

33. ábra: A. nomius által termelt aflatoxinok $(\mu \mathrm{g} / \mathrm{ml})$ valamint a telepek száraztömegének (g) időbeni változása fahéj illóolajos kezelést követően. Alkalmazott fahéj illóolaj koncentrációk a légtérben: A: kontroll minták, B: $0,05 \mathrm{mg} / \mathrm{cm}^{3}, \mathrm{C}: 0,105 \mathrm{mg} / \mathrm{cm}^{3}, \mathrm{D}: 0,21$ $\mathrm{mg} / \mathrm{cm}^{3}, \mathrm{E}: 0,42 \mathrm{mg} / \mathrm{cm}^{3}$ 
$\mathrm{Az}$ A. nomius által termelt toxinok arányát tekintve elmondható, hogy a fahéj illóolajjal történő kezelés hatására az inkubáció elején (3. nap) AFB2 arányának jelentősebb emelkedését detektáltuk, amely alacsonyabb AFG1 aránnyal párosult (34. ábra).

Inkubációs periódusonként, a kontrollokhoz képest nagyobb arányú változást a legkisebb $\left(0,05 \mathrm{mg} / \mathrm{cm}^{3}\right)$ és a legnagyobb $\left(0,42 \mathrm{mg} / \mathrm{cm}^{3}\right)$ illóolaj koncentrációnál tapasztaltunk. Ez esetekben az AFB1 arányok magasabbak voltak a kezelt mintákban az AFG1 arány rovására. A kontroll mintákhoz képest a 12. napra az AFG1 aránya szignifikánsan csökkent $0,05 \mathrm{mg} / \mathrm{cm}^{3}$ fahéj illóolaj alkalmazása esetén $(\mathrm{P} \leq 0,0001)$ és 0,42 $\mathrm{mg} / \mathrm{cm}^{3}$ esetén is $(\mathrm{P} \leq 0,001)$. A 15 . napra bekövetkezett változás (AFG1 arányának csökkenése) úgyszintén szignifikáns mindkét, már említett illóolaj koncentráció esetén: 0,05 $\mathrm{mg} / \mathrm{cm}^{3}$ fahéj illóolaj alkalmazásánál $\mathrm{P} \leq 0,001,0,42 \mathrm{mg} / \mathrm{cm}^{3}$ koncentrációnál $\mathrm{P} \leq 0,05$.

A legkisebb koncentrációjú $\left(0,05 \mathrm{mg} / \mathrm{cm}^{3}\right)$ fahéj illóolaj alkalmazása mutatta a mintákban a legnagyobb arányú AFB1 jelenlétet, amely az aflatoxinok közül a legnagyobb toxicitással bír.

Az A. nomius esetében azt tapasztaltuk, hogy a fahéj illóolajos gőztérben növekvő telepek a kontrollokhoz képest nagyobb micéliumtömeggel rendelkeztek $(6,9,12,15$. napok), a hifák jelentősen megnyúltak, viszont az aflatoxin termelésre gátló hatást gyakorolt az illóolaj.

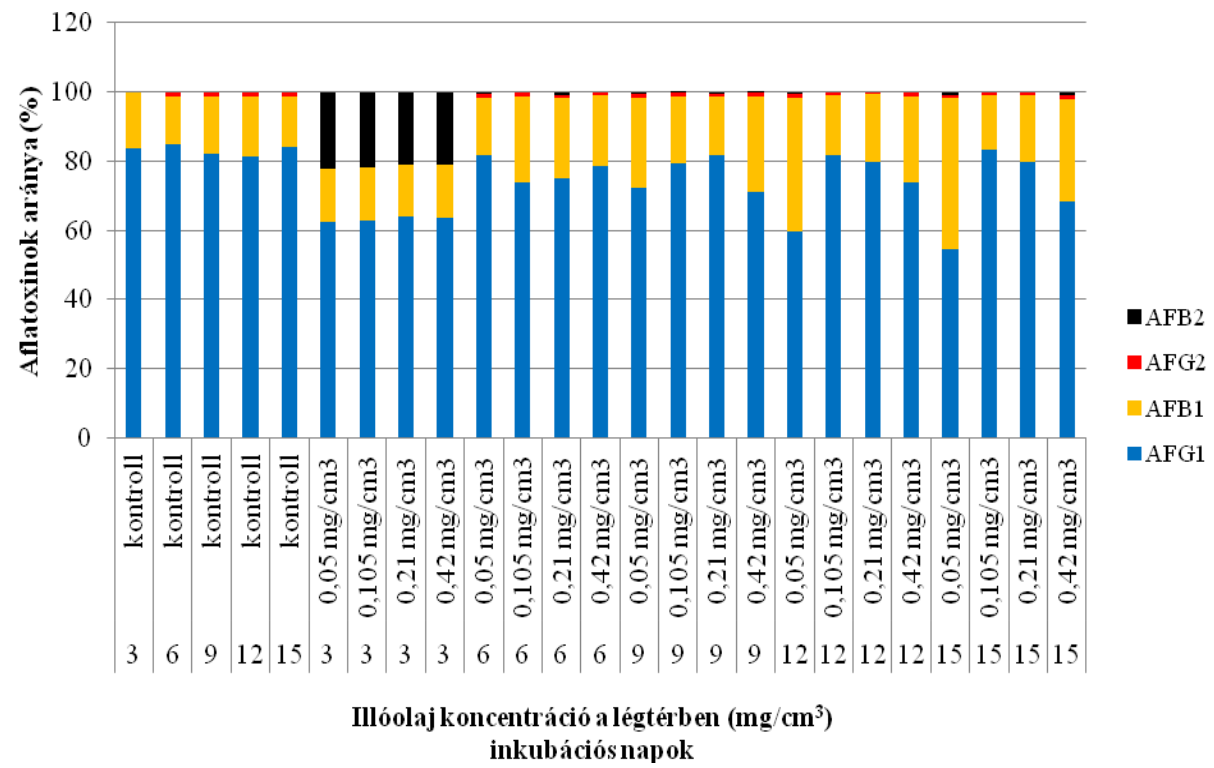

34. ábra: A. nomius által termelt aflatoxinok aránya (\%) a légtérben különböző koncentrációkban alkalmazott, fahéj illóolajos kezelést követően, az inkubációs idő figyelembe vételével. 


\subsection{Kezelés majoránna illóolajjal}

A majoránna illóolajjal végzett kísérleteknél, a légtér legalacsonyabb illóolaj koncentrációja esetén $\left(0,052 \mathrm{mg} / \mathrm{cm}^{3}\right)$ a kontrollhoz képest, megnövekedett a termelt aflatoxinok mennyisége (35. ábra), ami azonban megközelítőleg egy nagyságrenddel alacsonyabb volt, mint a citrom és boróka illóolaj esetében.

A többi koncentrációnál a majoránnaolaj összességében gátolta az aflatoxin termelést. Az inkubációs idő elöre haladásával, szinte valamennyi koncentrációnál, a rendszerben az aflatoxinok mennyiségének növekedése volt a jellemzö.

A micéliumtömeg döntően a 6. nap után kezdett el csökkenni a kisebb illóolaj koncentrációknál $\left(0,05\right.$ és $\left.0,105 \mathrm{mg} / \mathrm{cm}^{3}\right)$ (36. ábra). Az illóolaj mennyiségének növelése a légtérben, időben késleltette a micéliumtömeg maximumának elérését: $0,42 \mathrm{mg} / \mathrm{cm}^{3}$ koncentráció esetén a tömegcsökkenés már csak a 12. naptól következett be.

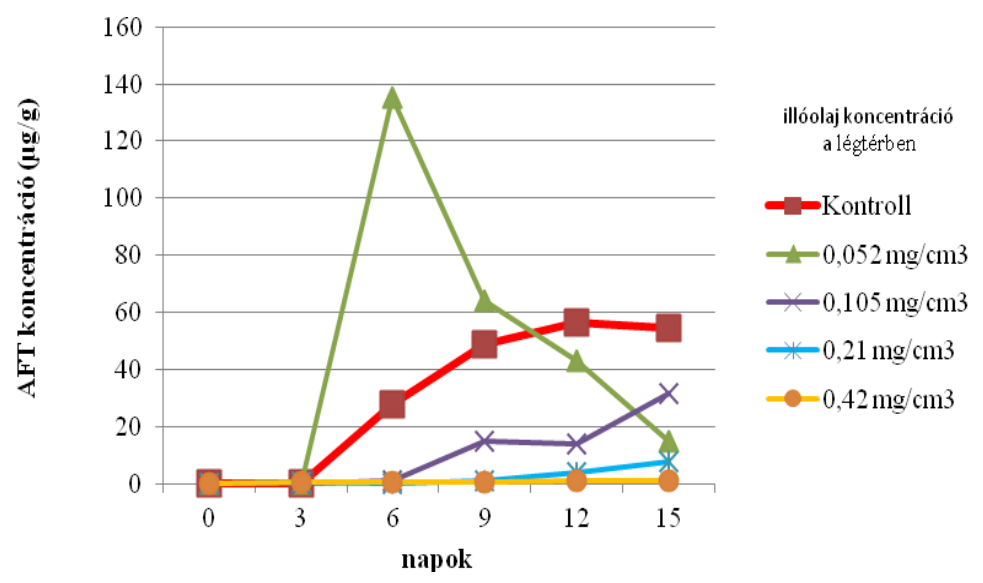

35. ábra: Az A. nomius által termelt, micéliumtömegre vonatkoztatott összes aflatoxin $(\mu \mathrm{g} / \mathrm{g})$ időbeli változása majoránna illóolaj gőztérben. 
A

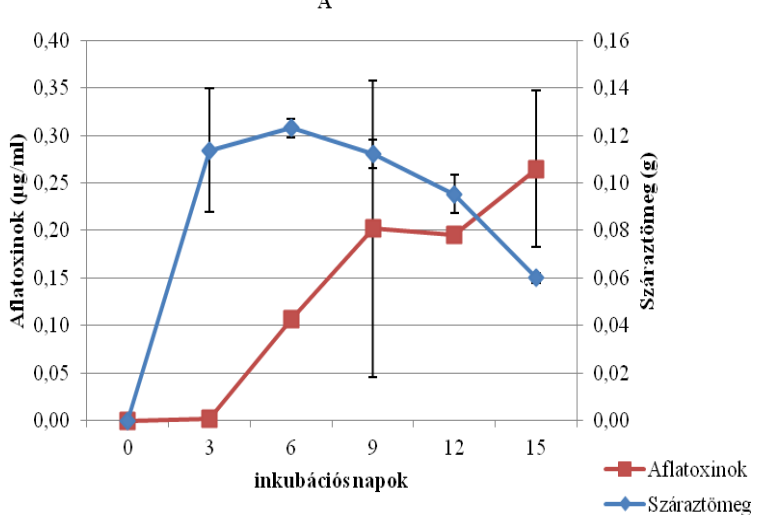

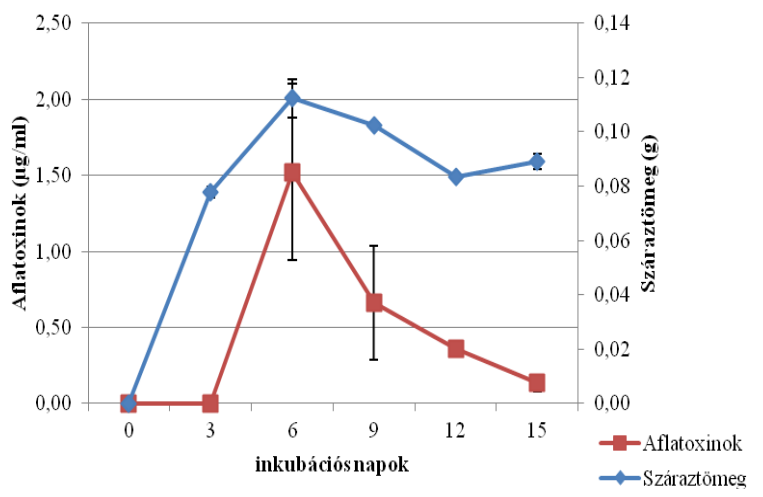

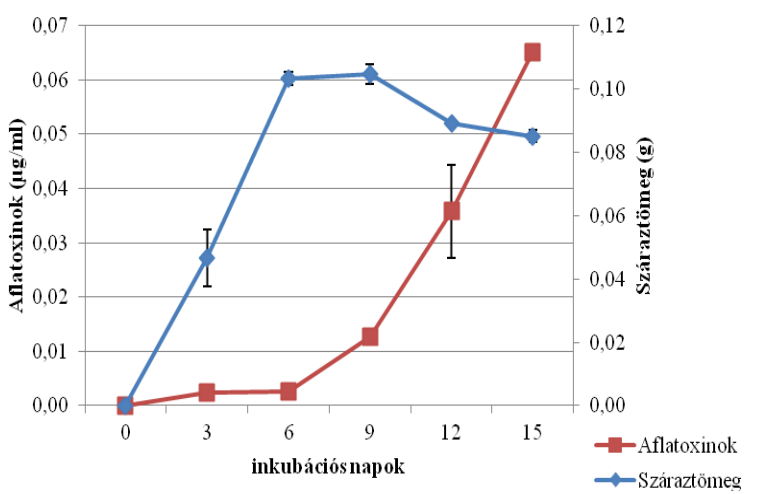

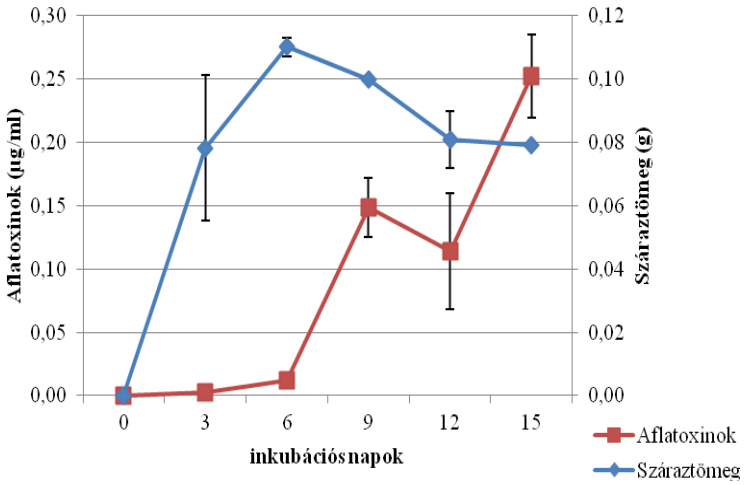

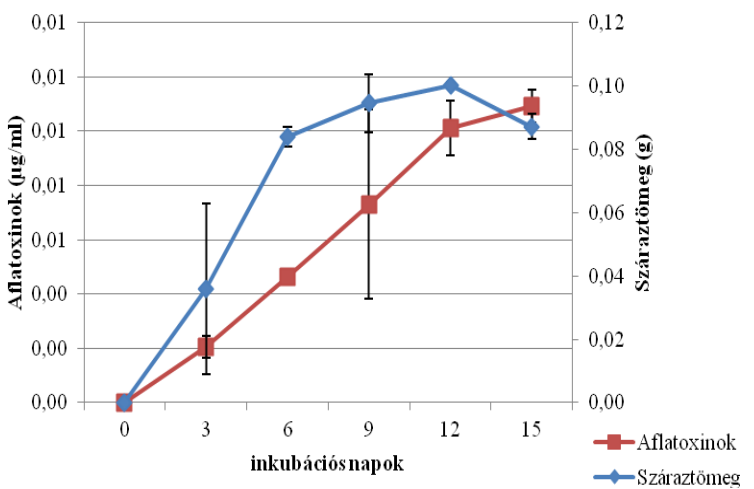

36. ábra: A. nomius által termelt aflatoxinok $(\mu \mathrm{g} / \mathrm{ml})$ valamint a telepek száraztömegének (g) időbeni változása majoránna illóolajos kezelést követően. Alkalmazott majoránna illóolaj koncentrációk a légtérben: A: kontroll minták, B: $0,05 \mathrm{mg} / \mathrm{cm}^{3}, \mathrm{C}: 0,105 \mathrm{mg} / \mathrm{cm}^{3}$, D: $0,21 \mathrm{mg} / \mathrm{cm}^{3}, \mathrm{E}: 0,42 \mathrm{mg} / \mathrm{cm}^{3}$

A majoránna illóolajjal kezelt mintákban is az inkubáció elején, a 3. napon tapasztaltuk az AFB2 toxin legnagyobb arányú jelenlétét. A majoránna illóolajjal történő kezelés hatására az aflatoxinok arányának markáns változása következett be a 9., 12., 15. napokra. Az AFG1 
aránya lecsökkent, a legnagyobb toxicitással bíró AFB1 aránya pedig megnövekedett az illóolaj mind nagyobb, mind kisebb koncentrációban történő alkalmazása esetén. Az inkubációs idő előrehaladtával az arányok megváltozása még jelentősebb mértékü lett (37. ábra).

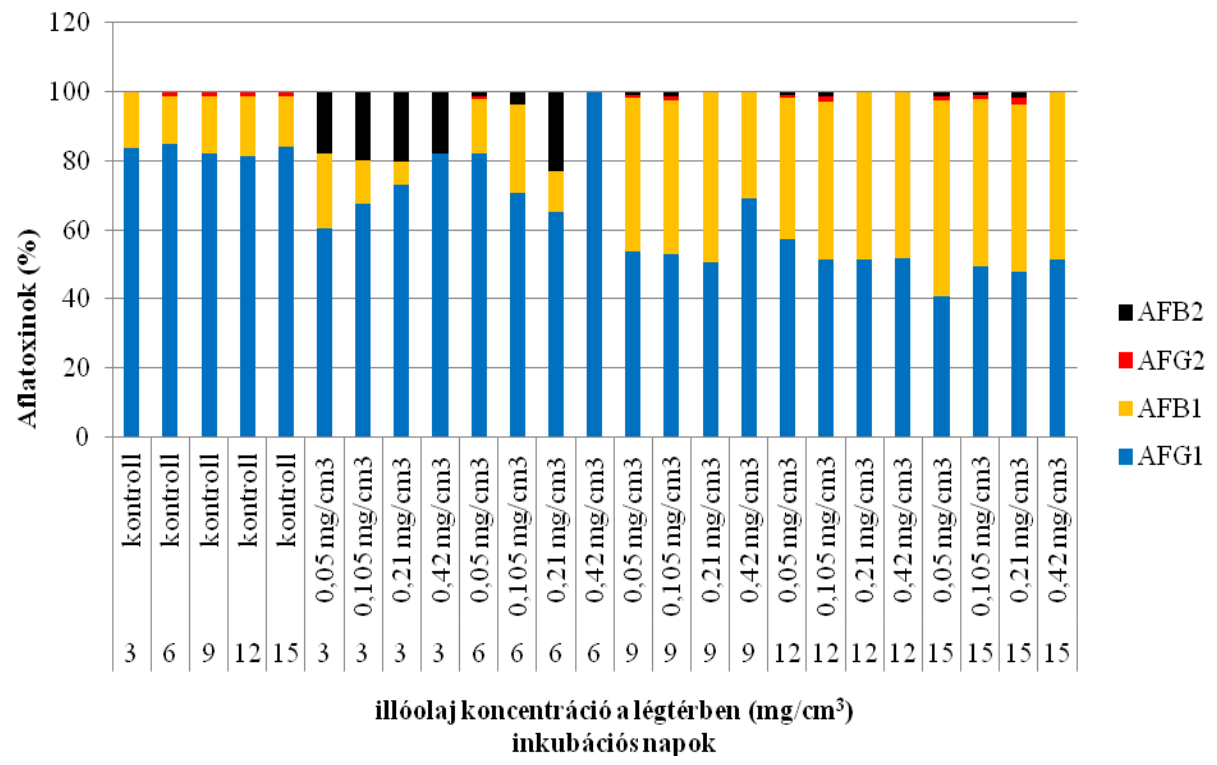

37. ábra: A. nomius által termelt aflatoxinok aránya (\%) a légtérben különböző koncentrációkban alkalmazott, majoránna illóolajos kezelést követően, az inkubációs idő figyelembe vételével.

\subsection{Kezelés muskotályzsálya illóolajjal}

Az A. nomius minták muskotályzsálya illóolajjal történő kezelésekor, mérhető aflatoxin tartalmat az inkubáció 6. napján tudtunk kimutatni. A 6. napon a kezelt minták aflatoxin tartalma a kontroll minták toxintartalma alatt maradt, azonban a 9. napon, föként a légtér alacsony, illetve közepes illóolaj koncentrációjánál már az illóolaj toxintermelést serkentő hatását mutatták az adatok (38. ábra). Maximális micélium száraztömeget a 6. napon mértünk mind a kezelt, mind a kezeletlen, kontroll minták esetében. Több eset is előfordult, amikor nem következett be a micéliumtömeggel párhuzamosan a minták aflatoxintartalmának csökkenése (39. ábra).

A termelt aflatoxinok mennyiségét igazán hatékonyan csak a legnagyobb koncentrációban $\left(0,42 \mathrm{mg} / \mathrm{cm}^{3}\right)$ alkalmazott muskotályzsálya illóolajos kezelés tudta csökkenteni. A majoránna illóolajhoz hasonlóan itt is egy nagyságrenddel alacsonyabb volt a termelődött aflatoxinok mennyisége a boróka és citrom illóolajos kezelésekhez képest. 


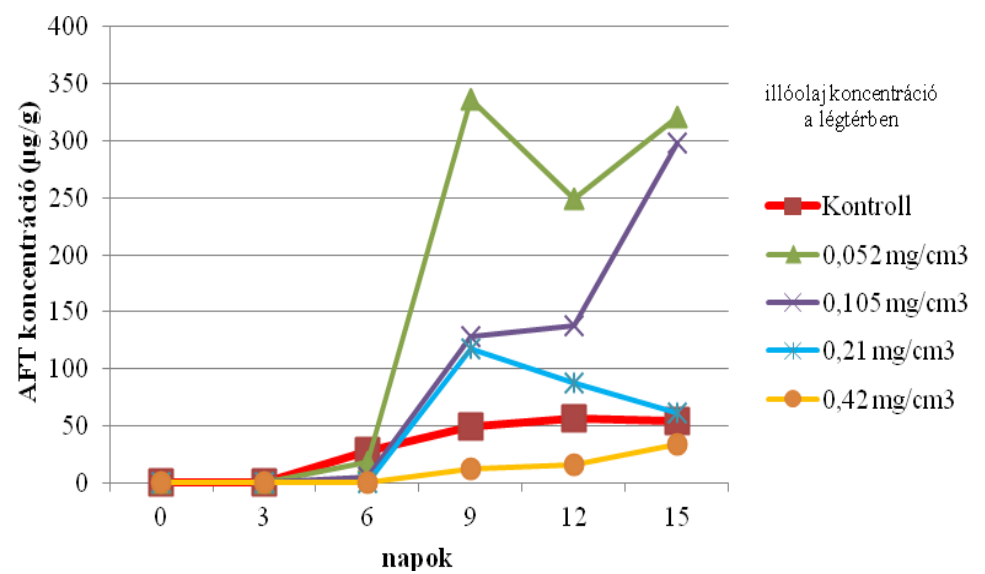

38. ábra: $\mathrm{Az}$ A. nomius által termelt, micéliumtömegre vonatkoztatott összes aflatoxin $(\mu \mathrm{g} / \mathrm{g})$ időbeli változása muskotályzsálya illóolaj gőztérben. 


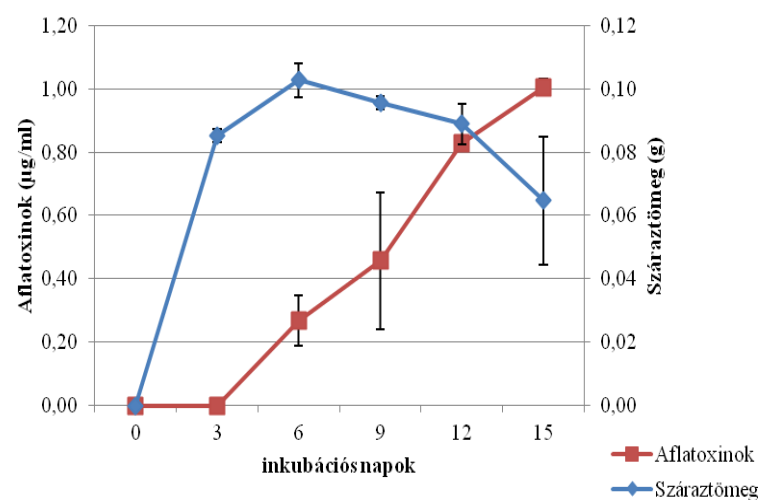

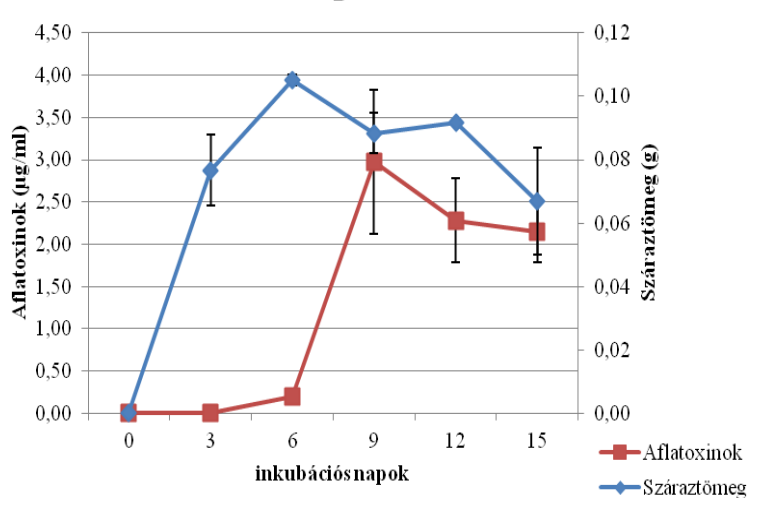

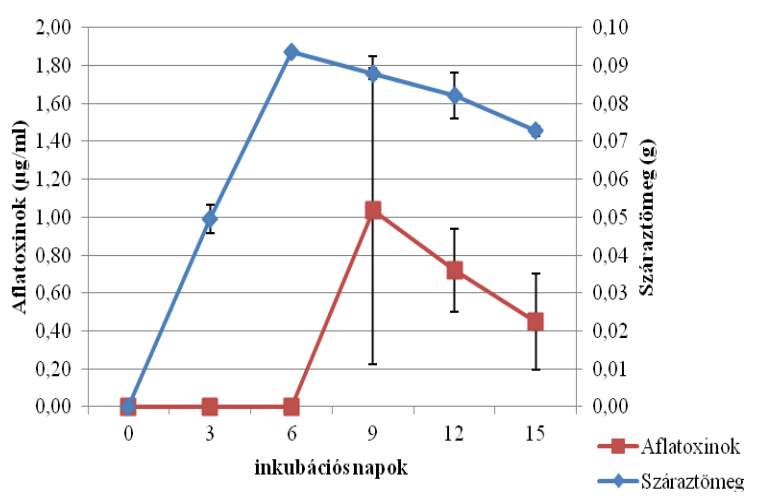

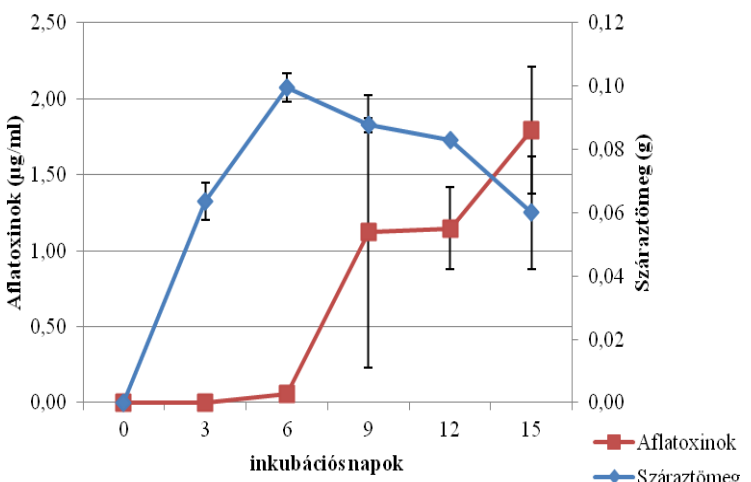

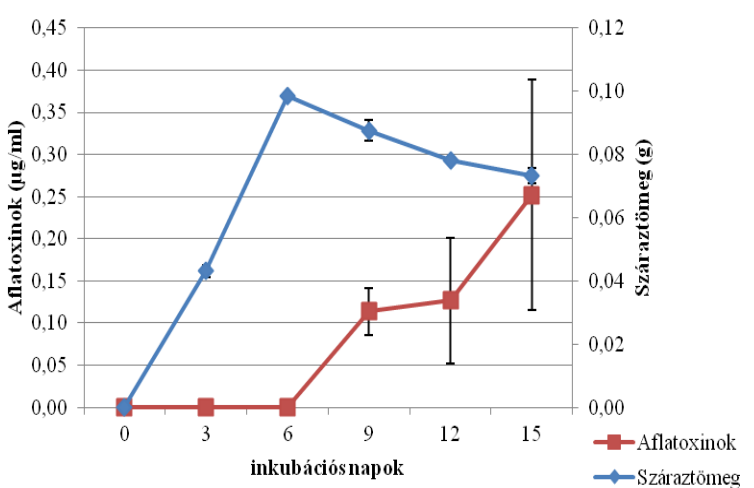

39. ábra: A. nomius által termelt aflatoxinok $(\mu \mathrm{g} / \mathrm{ml})$ valamint a telepek száraztömegének (g) időbeni változása muskotályzsálya illóolajos kezelést követően. Alkalmazott muskotályzsálya illóolaj koncentrációk a légtérben: A: kontroll minták, B: $0,05 \mathrm{mg} / \mathrm{cm}^{3}$, C: $0,105 \mathrm{mg} / \mathrm{cm}^{3}$, D: $0,21 \mathrm{mg} / \mathrm{cm}^{3}$, E: $0,42 \mathrm{mg} / \mathrm{cm}^{3}$

A muskotályzsálya illóolajos kezelés hatásáról elmondható, hogy a kis mennyiségü illóolajjal kezelt mintákhoz képest $\left(0,05 \mathrm{mg} / \mathrm{cm}^{3}\right)$, a nagyobb mennyiségü illóolajat $(0,21$ és $0,42 \mathrm{mg} / \mathrm{cm}^{3}$ ) tartalmazó légtereknél az AFB1 arányának csökkenésével megnövekedett a minták AFG1 tartalma. Az arányok változásában az idő és a koncentrációfüggés is kimutatható volt (40. ábra). 


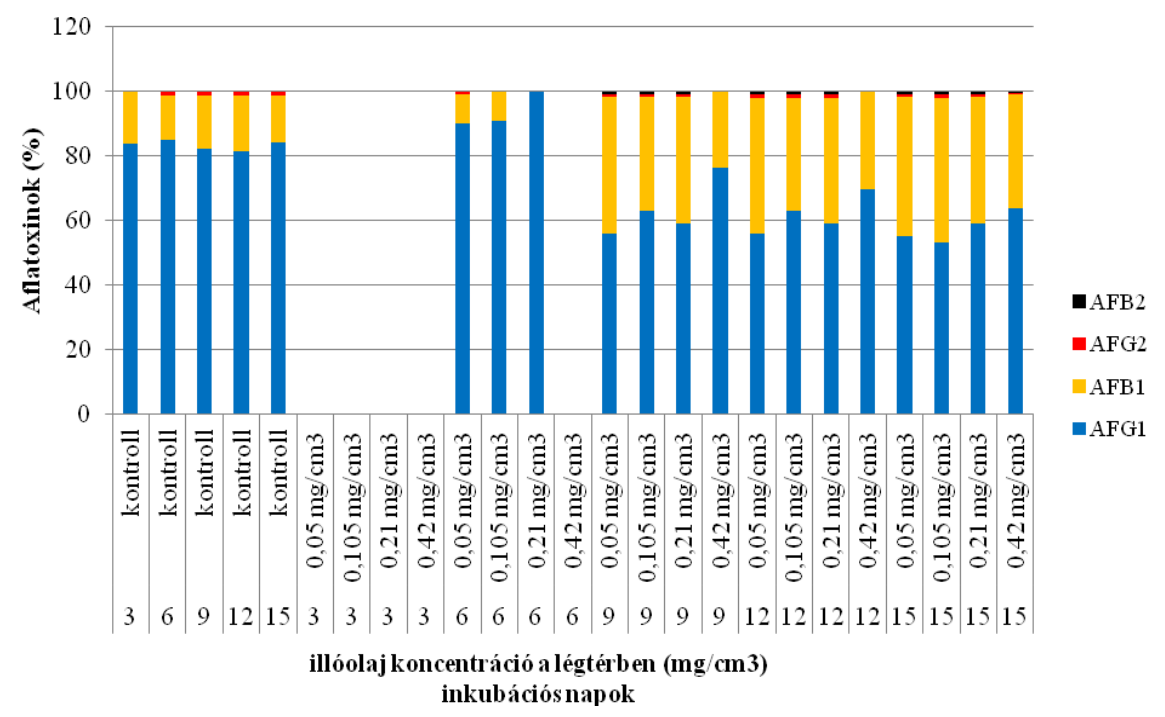

40. ábra: A. nomius által termelt aflatoxinok aránya (\%) a légtérben különböző koncentrációkban alkalmazott, muskotályzsálya illóolajos kezelést követően, az inkubációs idő figyelembe vételével. A kezelés 3. napján nem volt kimutatható mennyiségü aflatoxin.

\subsubsection{A. parasiticus aflatoxin termelése}

\subsection{Kezelés boróka illóolajjal}

Az A. parasiticus minták esetében a kezeletlen mintákhoz képest a borókaolaj csökkentette a minták aflatoxin tartalmát. A legnagyobb gátlást a legnagyobb, azaz a 0,42 $\mathrm{mg} / \mathrm{cm}^{3}$ koncentrációnál tapasztaltunk (41. ábra). A micéliumtömeg szintén csökkent az illóolajos kezelés hatására. Az A. nomius-hoz hasonlóan, az A. parasiticus esetében is megfigyeltük, hogy a micéliumtömeg a 6 . napon, az aflatoxin tartalom pedig a 12 . napon érte el a maximumát (42. ábra).

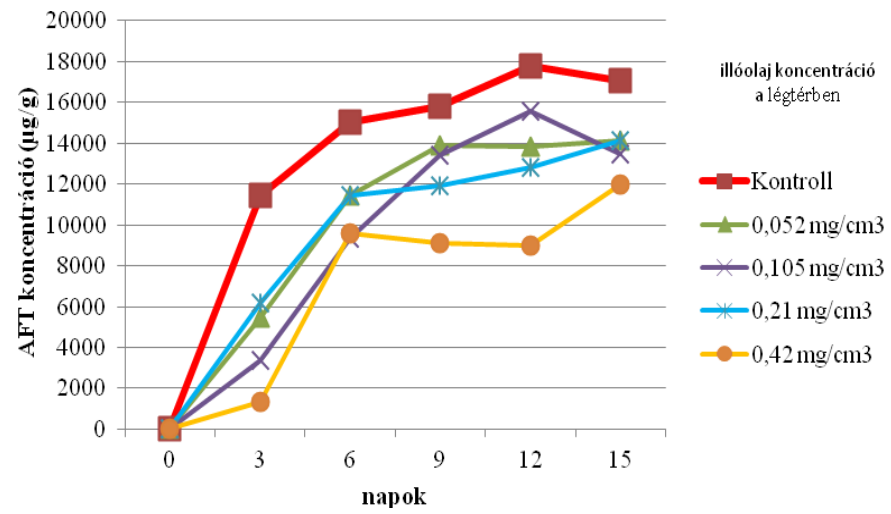

41. ábra: Az A. parasiticus által termelt, micéliumtömegre vonatkoztatott összes aflatoxin $(\mu \mathrm{g} / \mathrm{g})$ időbeli változása boróka illóolaj gőztérben. 

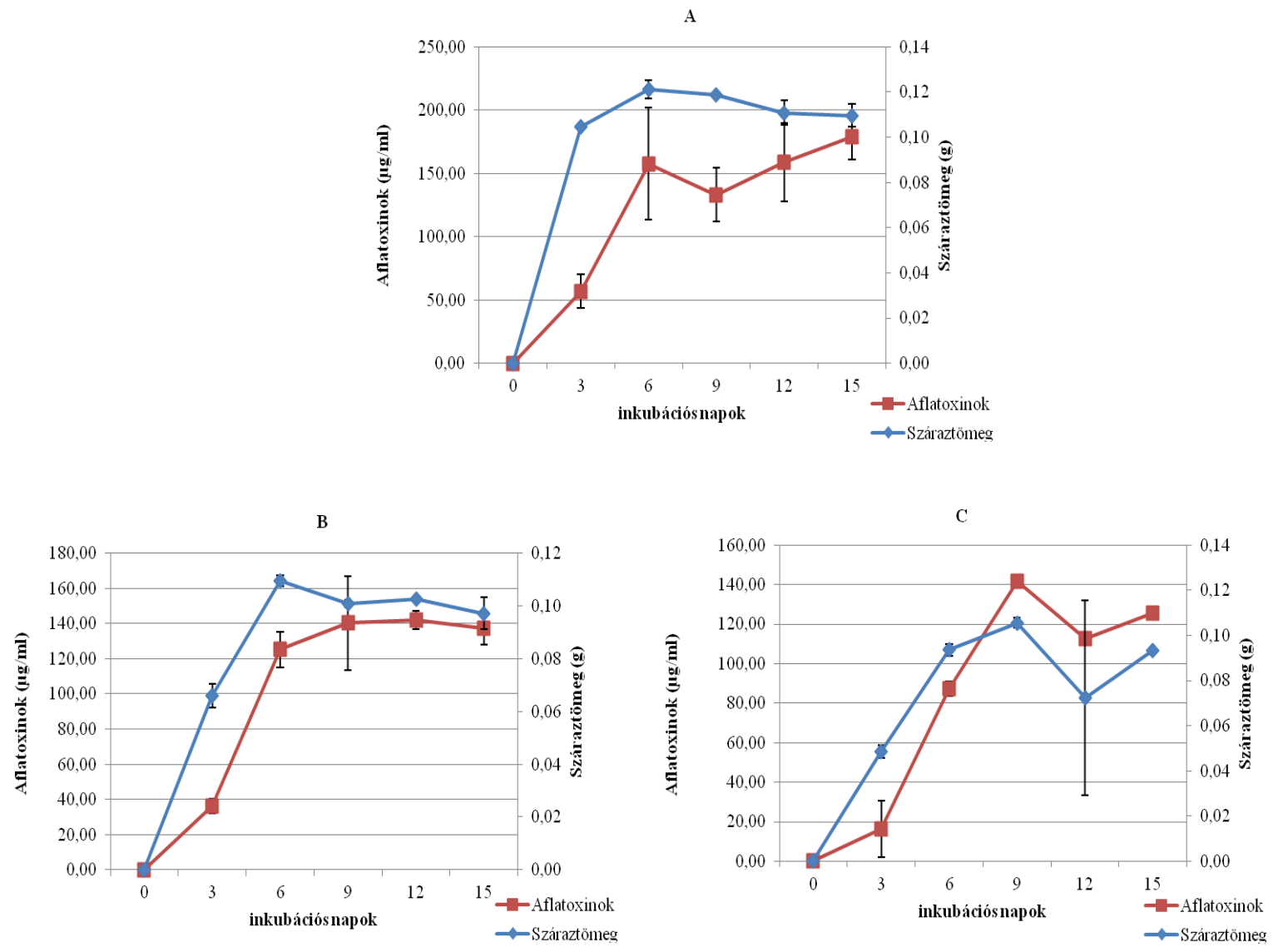

D
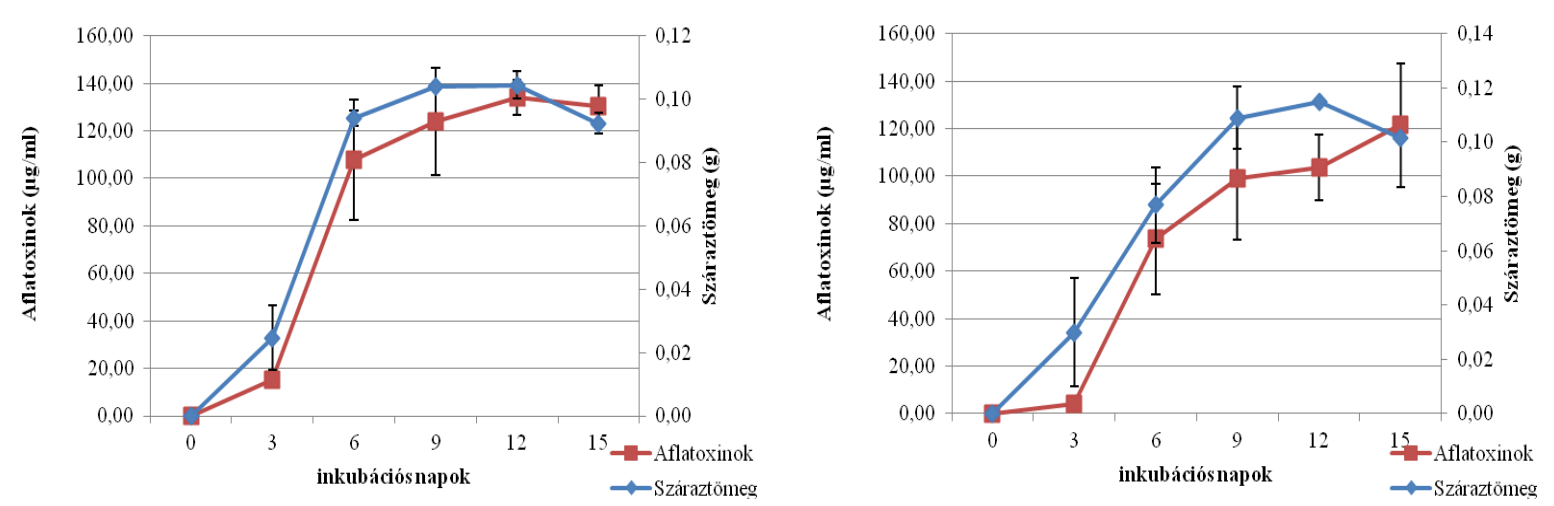

42. ábra: $A$. parasiticus által termelt aflatoxinok $(\mu \mathrm{g} / \mathrm{ml})$ valamint a telepek száraztömegének ( $\mathrm{g}$ ) időbeni változása boróka illóolajos kezelést követően. Alkalmazott boróka illóolaj koncentrációk a légtérben: A: kontroll minták, B: $0,05 \mathrm{mg} / \mathrm{cm}^{3}, \mathrm{C}: 0,105$ $\mathrm{mg} / \mathrm{cm}^{3}$, D: $0,21 \mathrm{mg} / \mathrm{cm}^{3}$, E: $0,42 \mathrm{mg} / \mathrm{cm}^{3}$

Az összes aflatoxin közül az AFG1 fordult elő a mintákban a legnagyobb, míg az AFB2 toxin a legkisebb mennyiségben (43. ábra). A boróka illóolaj alkalmazása a 3. naptól megnövelte az AFG1, és csökkentette az AFB1 toxin mennyiségét. A növekvő illóolaj 
koncentrációknak nem volt jelentős hatása a mintákon belül az egyes toxinok arányára, a kezelt és a kezeletlen minták között azonban szignifikáns volt a kimutatható különbség.

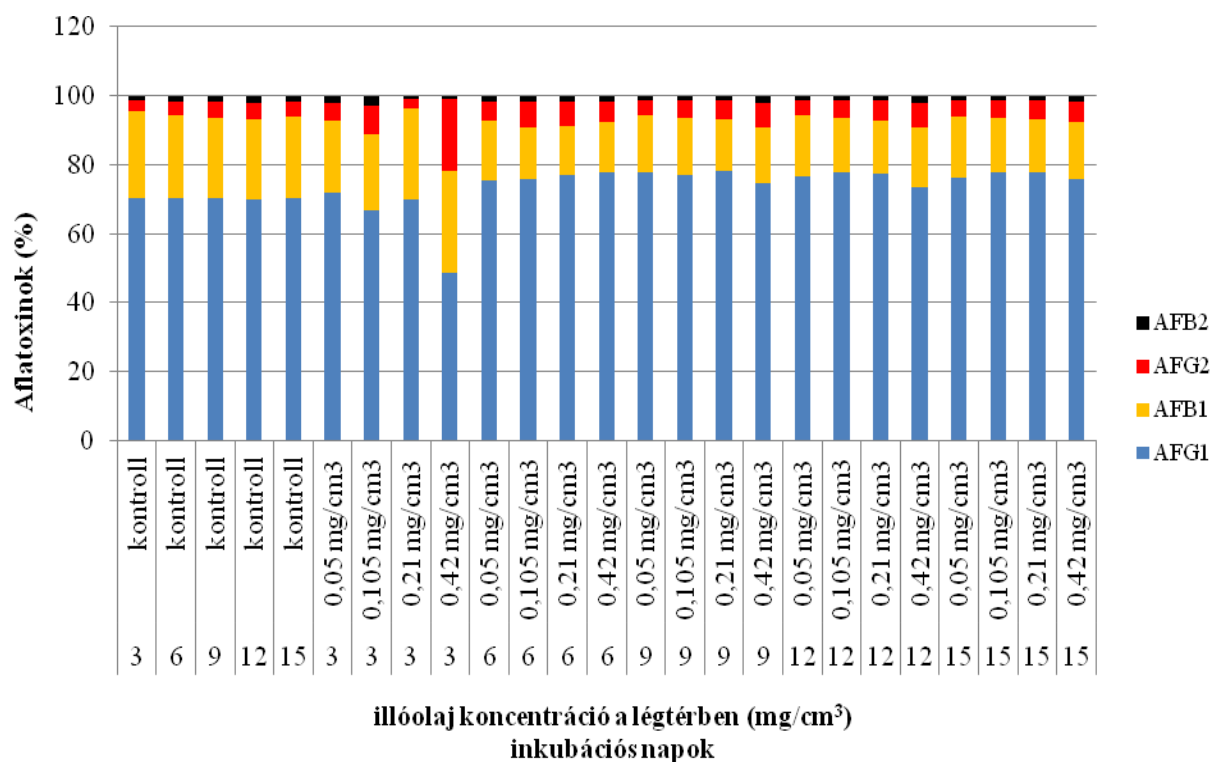

43. ábra: A. parasiticus által termelt aflatoxinok aránya (\%) a légtérben különböző koncentrációkban alkalmazott boróka illóolajos kezelést követően, az inkubációs idő figyelembe vételével.

\subsection{Kezelés citrom illóolajjal}

A citrom illóolaj, a boróka olajhoz hasonlóan, szintén csökkentette az aflatoxin termelést a kezeletlen, kontroll mintákhoz képest (44. ábra).

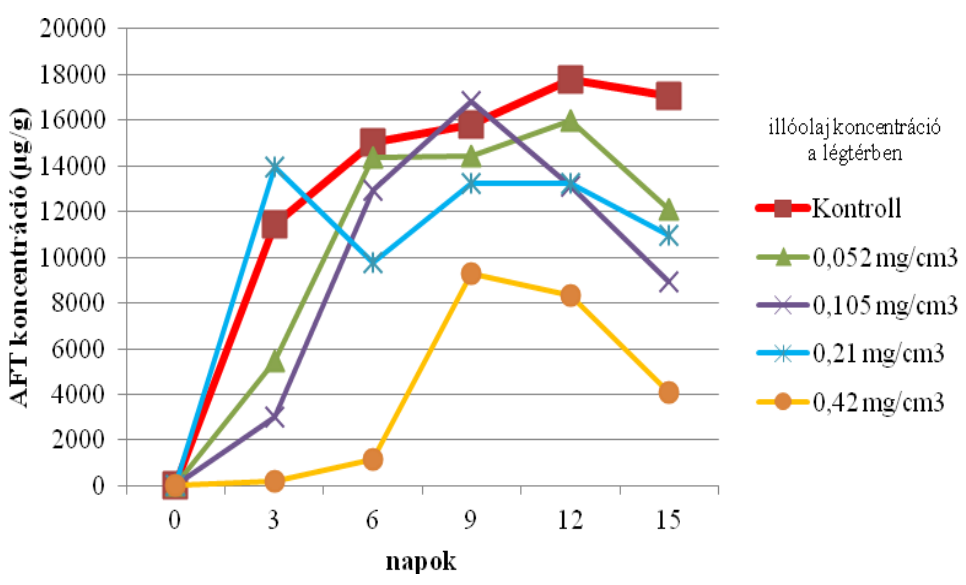

44. ábra: Az A. parasiticus által termelt, micéliumtömegre vonatkoztatott összes aflatoxin $(\mu \mathrm{g} / \mathrm{g})$ időbeli változása citrom illóolaj gőztérben. 
Ezekben a kísérletekben is azt tapasztaltuk, hogy a kezelt mintáknál követte egymást a micéliumok tömegének változási tendenciája és a termelt aflatoxinok rendszerben való jelenléte. A növekvő citrom illóolaj koncentráció hatására a micéliumtömegek a maximumukat később érték el, a 6. nap helyett a 12. napon (45. ábra).

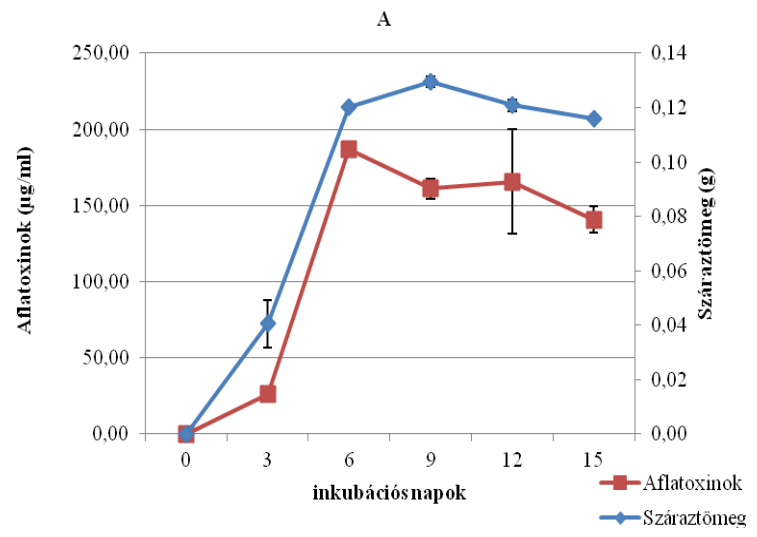

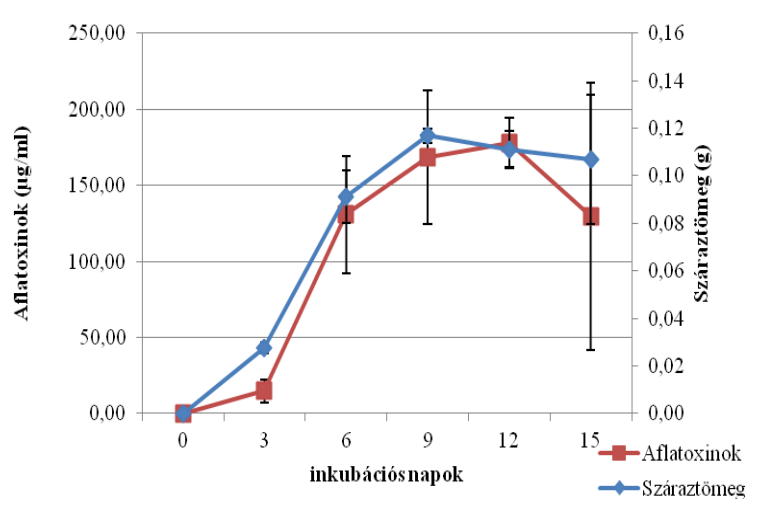

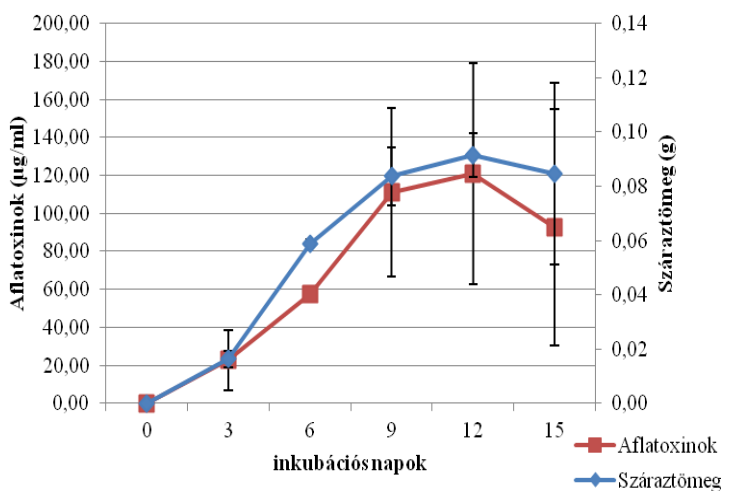

C

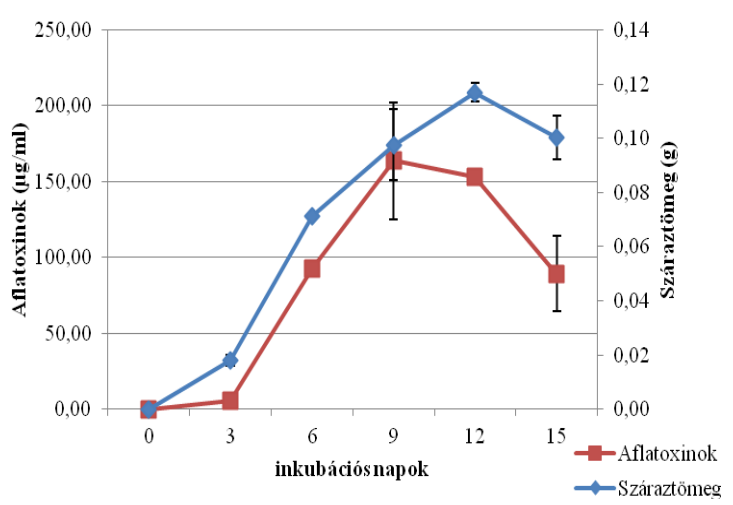

$\mathbf{E}$

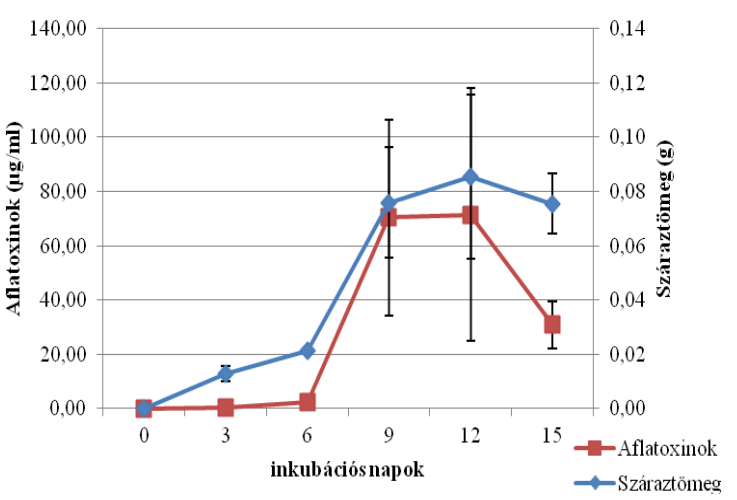

45. ábra: $A$. parasiticus által termelt aflatoxinok $(\mu \mathrm{g} / \mathrm{ml})$ valamint a telepek száraztömegének ( $\mathrm{g}$ ) időbeni változása citrom illóolajos kezelést követően. Alkalmazott citrom illóolaj koncentrációk a légtérben: A: kontroll minták, B: 0,05 mg/ $\mathrm{cm}^{3}, \mathrm{C}: 0,105$ $\mathrm{mg} / \mathrm{cm}^{3}$, D: $0,21 \mathrm{mg} / \mathrm{cm}^{3}$, E: $0,42 \mathrm{mg} / \mathrm{cm}^{3}$ 
A növekedésgátlási kísérletekben a citrom és a boróka illóolaj mutatkozott a legkevésbé hatékonynak, a folyadéktenyésztéses kísérletekben azonban ez a két illóolaj koncentrációtól függően gátolta az aflatoxintermelést.

A citrom illóolajat tartalmazó légtérben növekvő A. parasiticus hasonló arányban termelte a különböző aflatoxinokat, mint a boróka illóolajos kezelés esetén. A 9. naptól az AFB1 mennyisége inkubációs időtől és illóolaj koncentrációtól függetlenül csökkent (46. ábra).

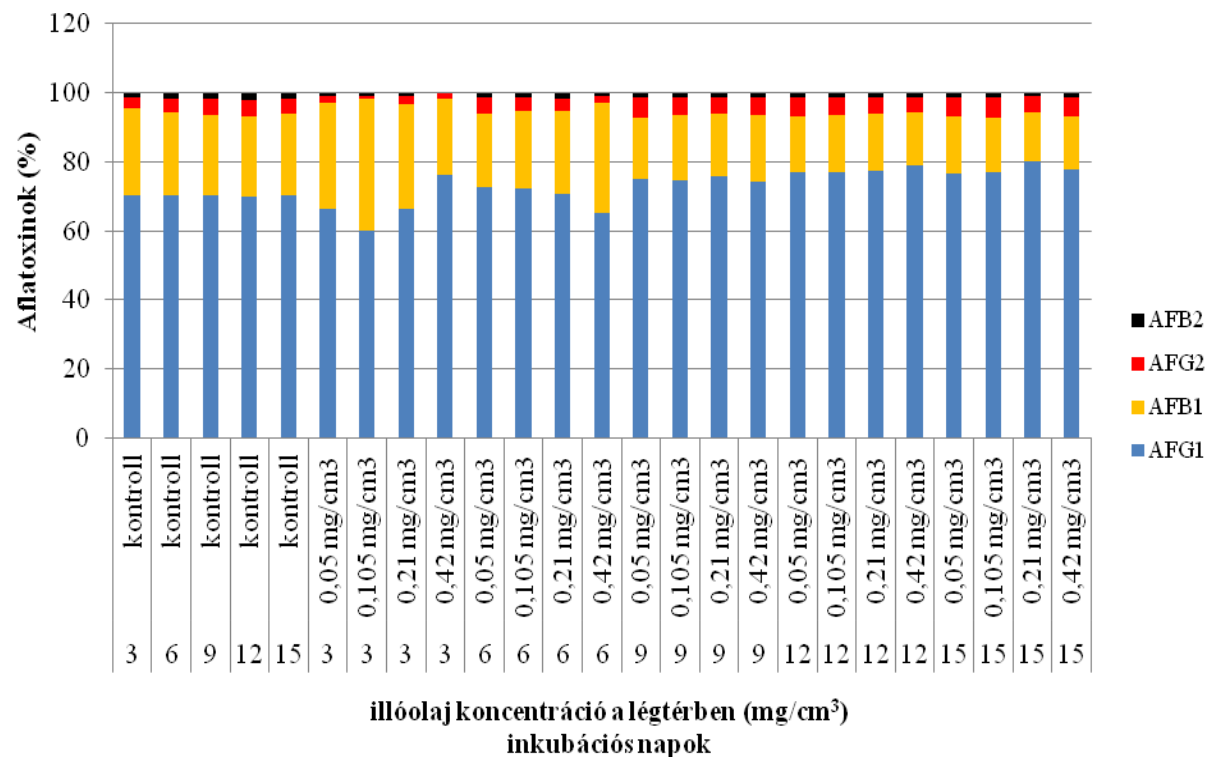

46. ábra: A. parasiticus által termelt aflatoxinok aránya (\%) a légtérben különböző koncentrációkban alkalmazott, citrom illóolajos kezelést követően, az inkubációs idő figyelembe vételével.

\subsection{Kezelés fahéj illóolajjal}

A fahéjolajjal kezelt minták esetében a rövid inkubációs idő (3., 6. nap) megnövekedett aflatoxin termelést eredményezett. Az inkubáció 12. napjára minden kezelt minta aflatoxin tartalma a kontroll minták aflatoxin tartalma alatt maradt. Ez a tendencia megfigyelhető a micéliumok száraztömegéhez viszonyított aflatoxin mennyiséget bemutató 47. ábrán. 


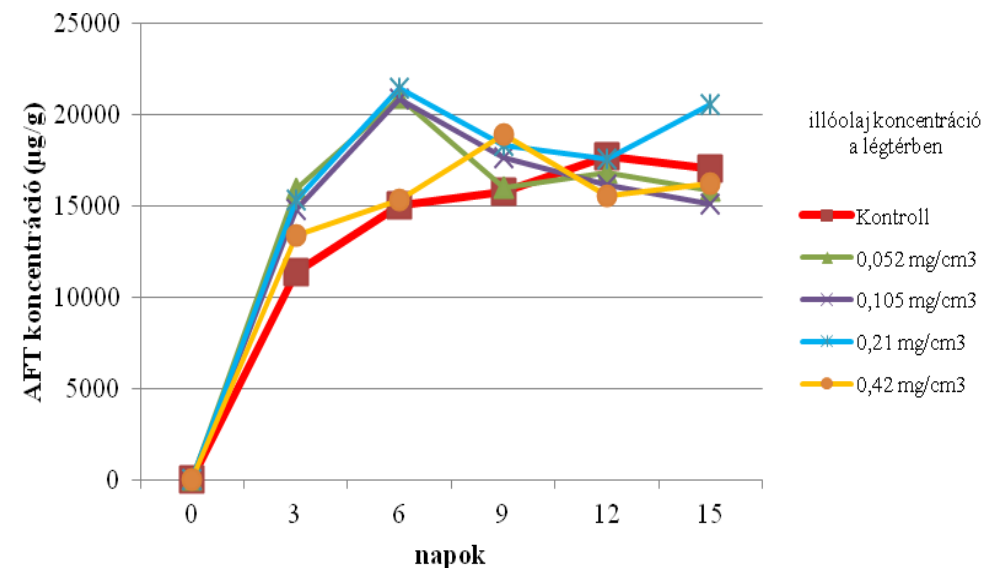

47. ábra: Az A. parasiticus által termelt, micéliumtömegre vonatkoztatott összes aflatoxin $(\mu \mathrm{g} / \mathrm{g})$ időbeli változása fahéj illóolaj gőztérben.

A termelt aflatoxinok mennyiségének csökkenése a kontrollok esetében a 12 . napon, a kezelt mintáknál a 6., illetve 9. napon következett be (48. ábra). 
A

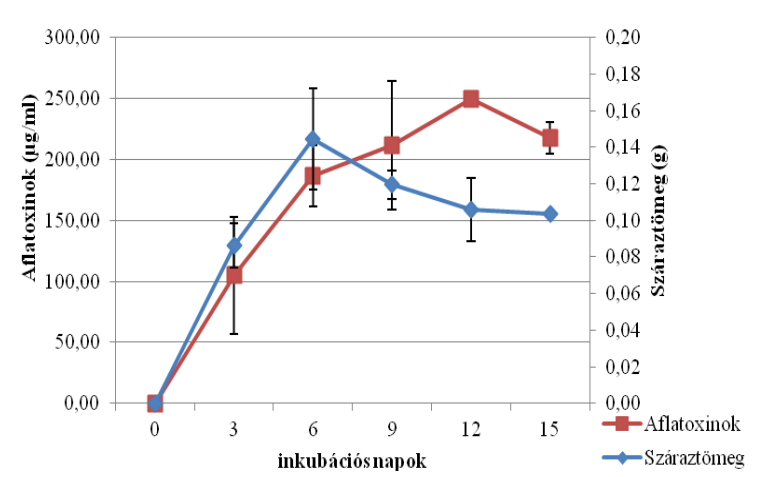

C

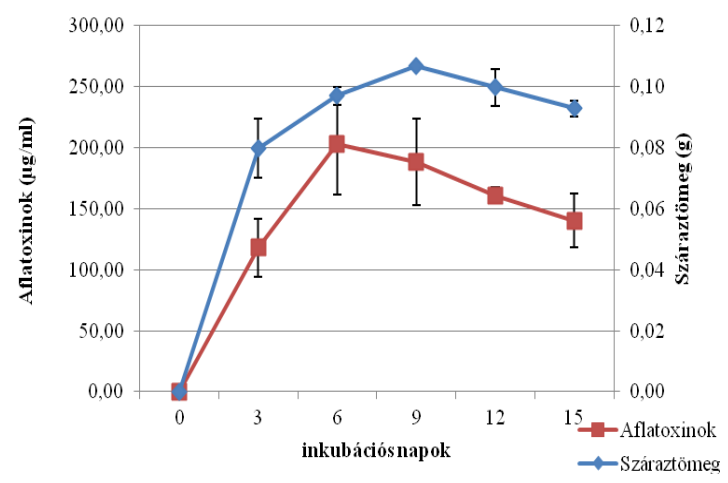

B

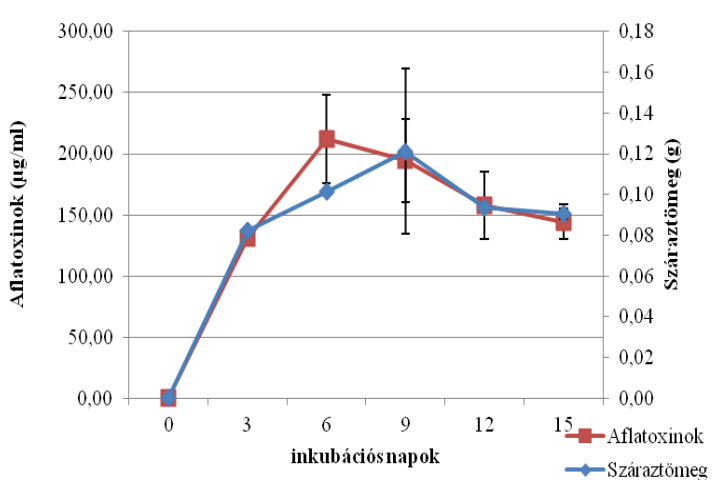

D

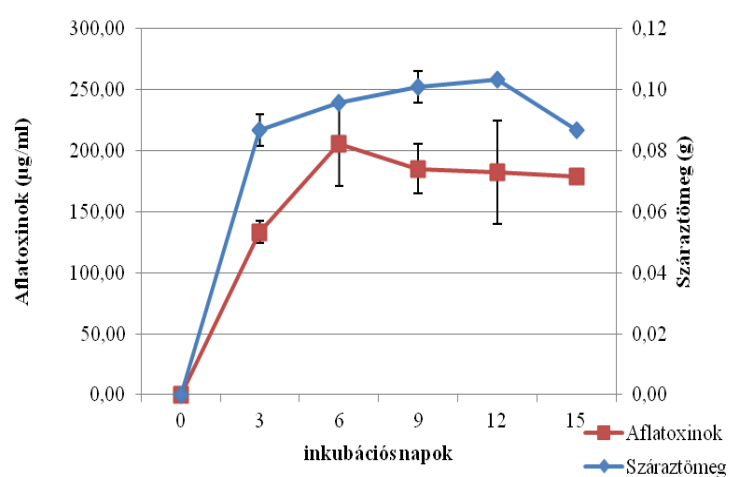

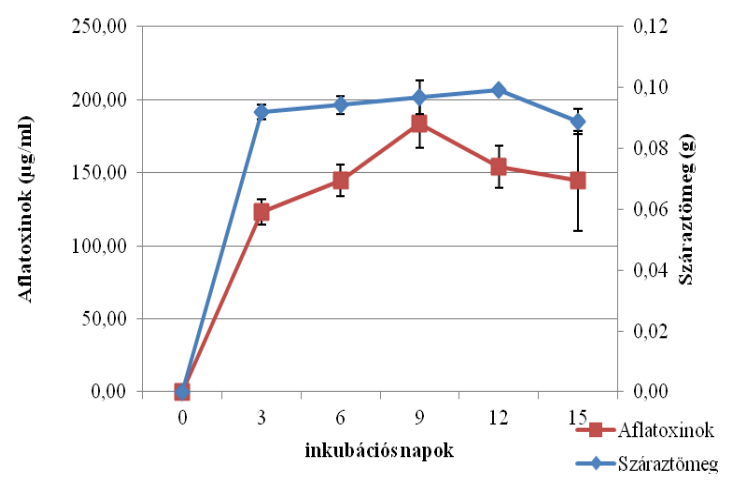

48. ábra: A parasiticus által termelt aflatoxinok $(\mu \mathrm{g} / \mathrm{ml})$ valamint a telepek száraztömegének (g) időbeni változása fahéj illóolajos kezelést követően. Alkalmazott fahéj illóolaj koncentrációk a légtérben: A: kontroll minták, B: $0,05 \mathrm{mg} / \mathrm{cm}^{3}, \mathrm{C}: 0,105 \mathrm{mg} / \mathrm{cm}^{3}, \mathrm{D}: 0,21$ $\mathrm{mg} / \mathrm{cm}^{3}$, E: $0,42 \mathrm{mg} / \mathrm{cm}^{3}$

Fahéj illóolajjal történő kezelés hatására a mintákban nem következett be lényeges változás az AFG1, AFB1, AFG2, AFB2 arányokban sem az idő, sem az alkalmazott illóolaj koncentráció függvényében (49. ábra). 


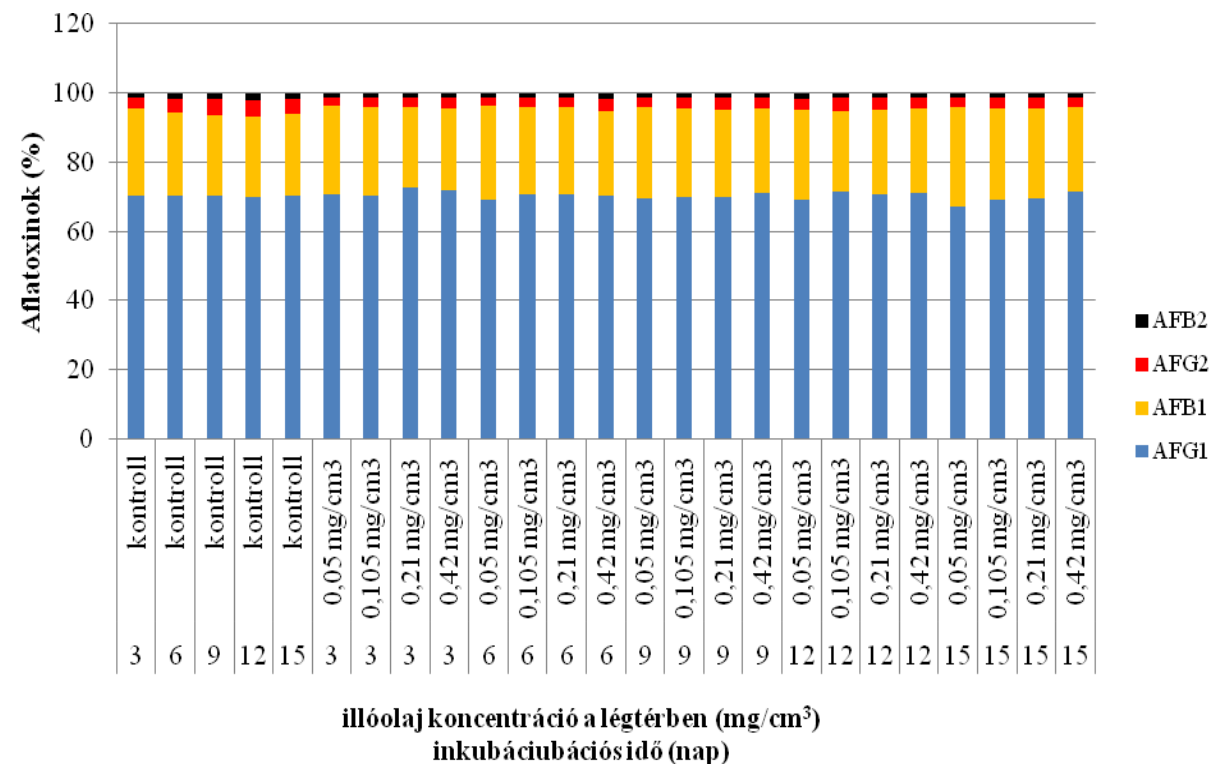

49. ábra: A. parasiticus által termelt aflatoxinok aránya (\%) a légtérben különböző koncentrációkban alkalmazott fahéj illóolajos kezelést követően, az inkubációs idő figyelembe vételével.

\subsection{Kezelés majoránna illóolajjal}

A majoránna illóolaj kis koncentrációkban serkentette az A. parasiticus aflatoxin termelését. A légtérbe vitt magasabb koncentrációjú majoránnaolaj $\left(0,21 \mathrm{mg} / \mathrm{cm}^{3}, 0,42\right.$ $\mathrm{mg} / \mathrm{cm}^{3}$ ) minden esetben visszafogott aflatoxintermelést eredményezett (50. ábra). A kezelések hatására, a telepek száraztömege és a mintákban mért aflatoxinok mennyisége, tendenciájukat tekintve együtt mozogtak (51. ábra).

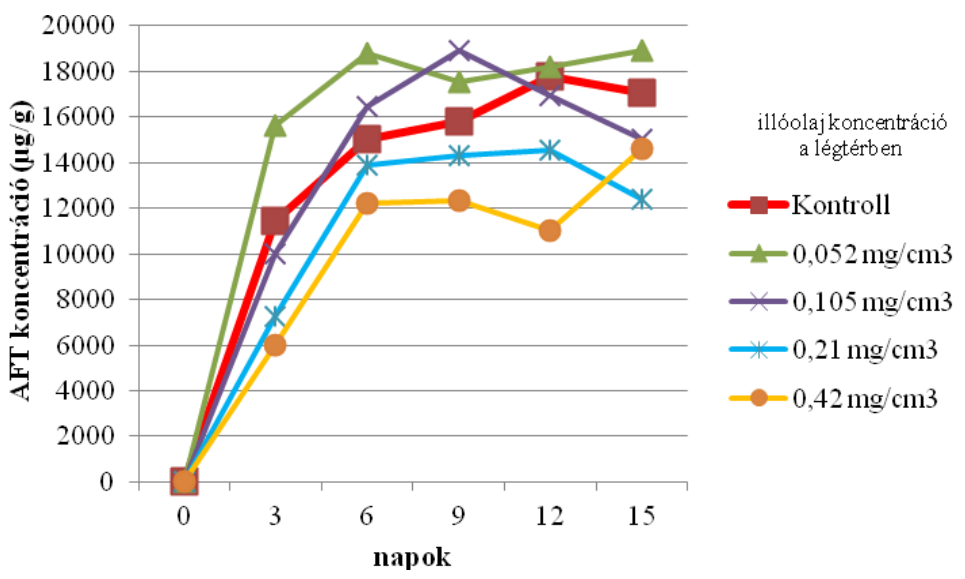

50. ábra: Az A. parasiticus által termelt, micéliumtömegre vonatkoztatott összes aflatoxin $(\mu \mathrm{g} / \mathrm{g})$ időbeli változása majoránna illóolaj gőztérben. 


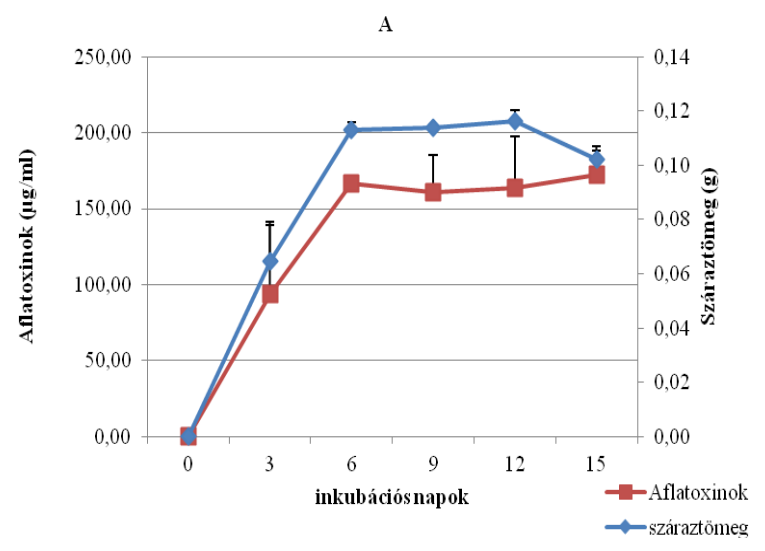

B

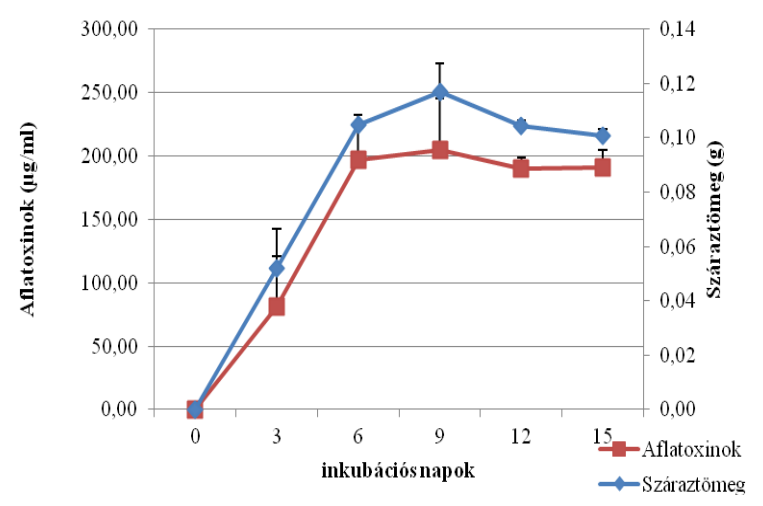

D

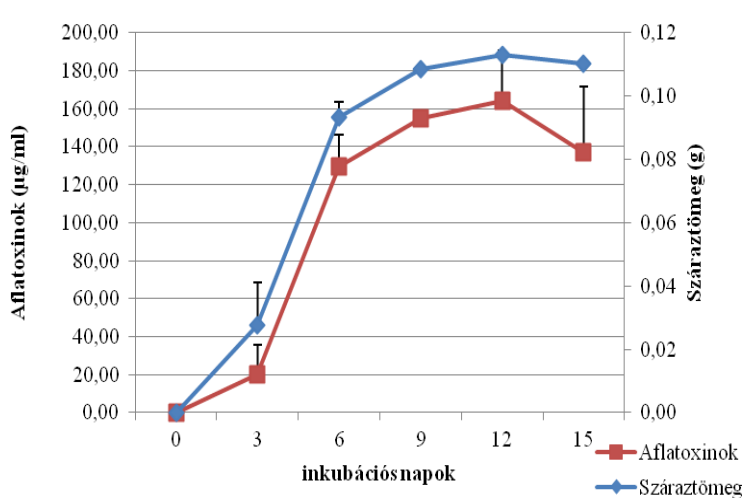

$\mathrm{C}$

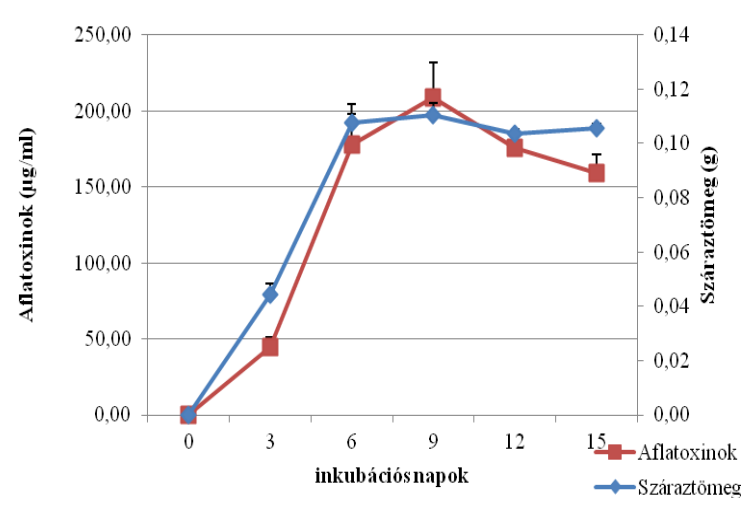

E

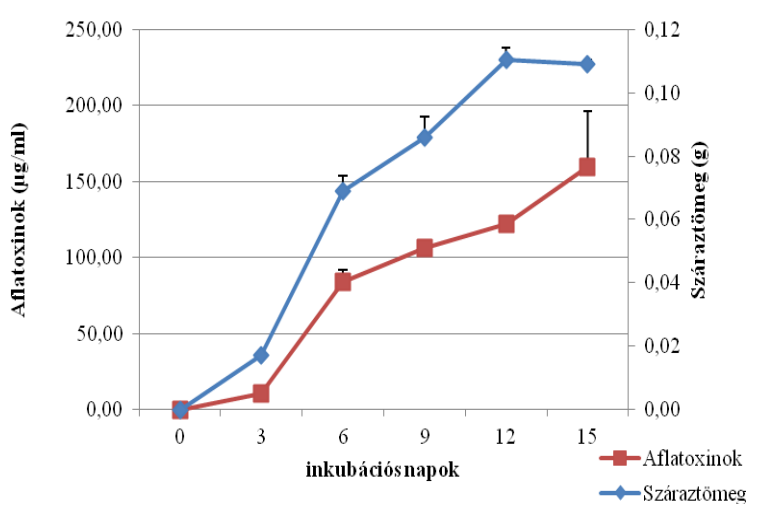

51. ábra: $A$. parasiticus által termelt aflatoxinok $(\mu \mathrm{g} / \mathrm{ml})$ valamint a telepek száraztömegének (g) időbeni változása majoránna illóolajos kezelést követően. Alkalmazott majoránna illóolaj koncentrációk a légtérben: A: kontroll minták, B: 0,05 $\mathrm{mg} / \mathrm{cm}^{3}, \mathrm{C}: 0,105 \mathrm{mg} / \mathrm{cm}^{3}, \mathrm{D}: 0,21 \mathrm{mg} / \mathrm{cm}^{3}, \mathrm{E}: 0,42 \mathrm{mg} / \mathrm{cm}^{3}$

A kezeletlen mintáknál nem volt tapasztalható az idö függvényében az egyes aflatoxinok arányának szignifikáns változása. A majoránna illóolajjal kezelt mintákban a légtér növekvő koncentrációja minden inkubációs periódusban növelte az AFB1 és 
csökkentette az AFG1 toxinok arányát. Az idő elörehaladtával nagyobb lett a kimutatható AFG2 és AFB2 mennyisége is (52. ábra).

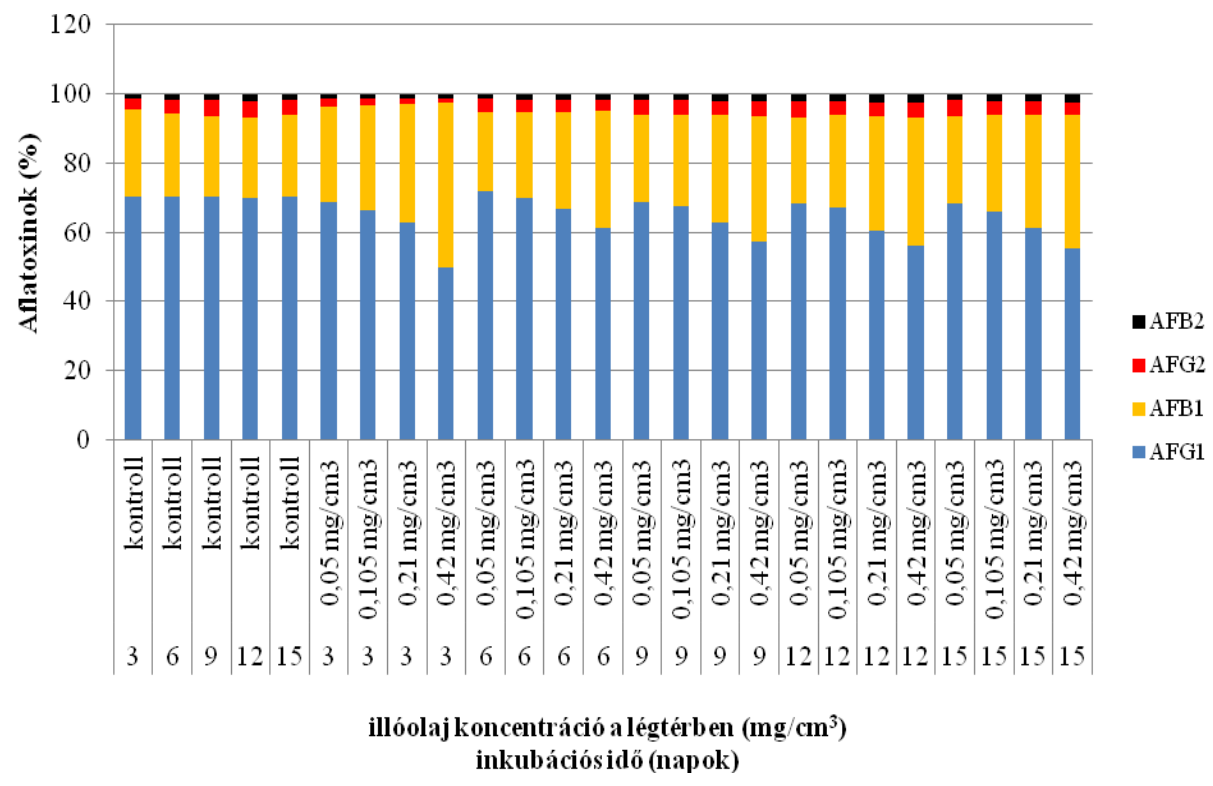

52. ábra: A. parasiticus által termelt aflatoxinok aránya (\%) a légtérben különböző koncentrációkban alkalmazott majoránna illóolajos kezelést követően, az inkubációs idő figyelembe vételével.

\subsection{Kezelés muskotályzsálya illóolajjal}

A muskotályzsálya illóolaj hatására, kivéve a legalacsonyab koncentrációt, valamennyi esetben a kontrollnál alacsonyabb aflatoxintartalmat mértünk az idő elörehaladtával (53. ábra).

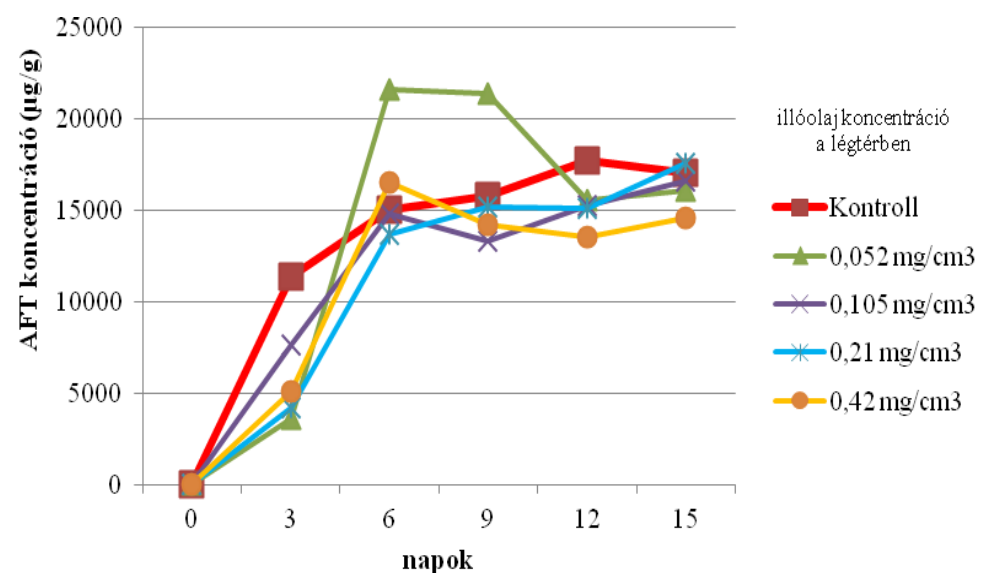

53. ábra: Az A. parasiticus által termelt, micéliumtömegre vonatkoztatott összes aflatoxin $(\mu \mathrm{g} / \mathrm{g})$ időbeli változása muskotályzsálya illóolaj gőztérben. 
A kezelések hatására a telepek száraztömege és a mintákban mért aflatoxinok mennyisége, tendenciájukat tekintve együtt mozogtak (54. ábra).
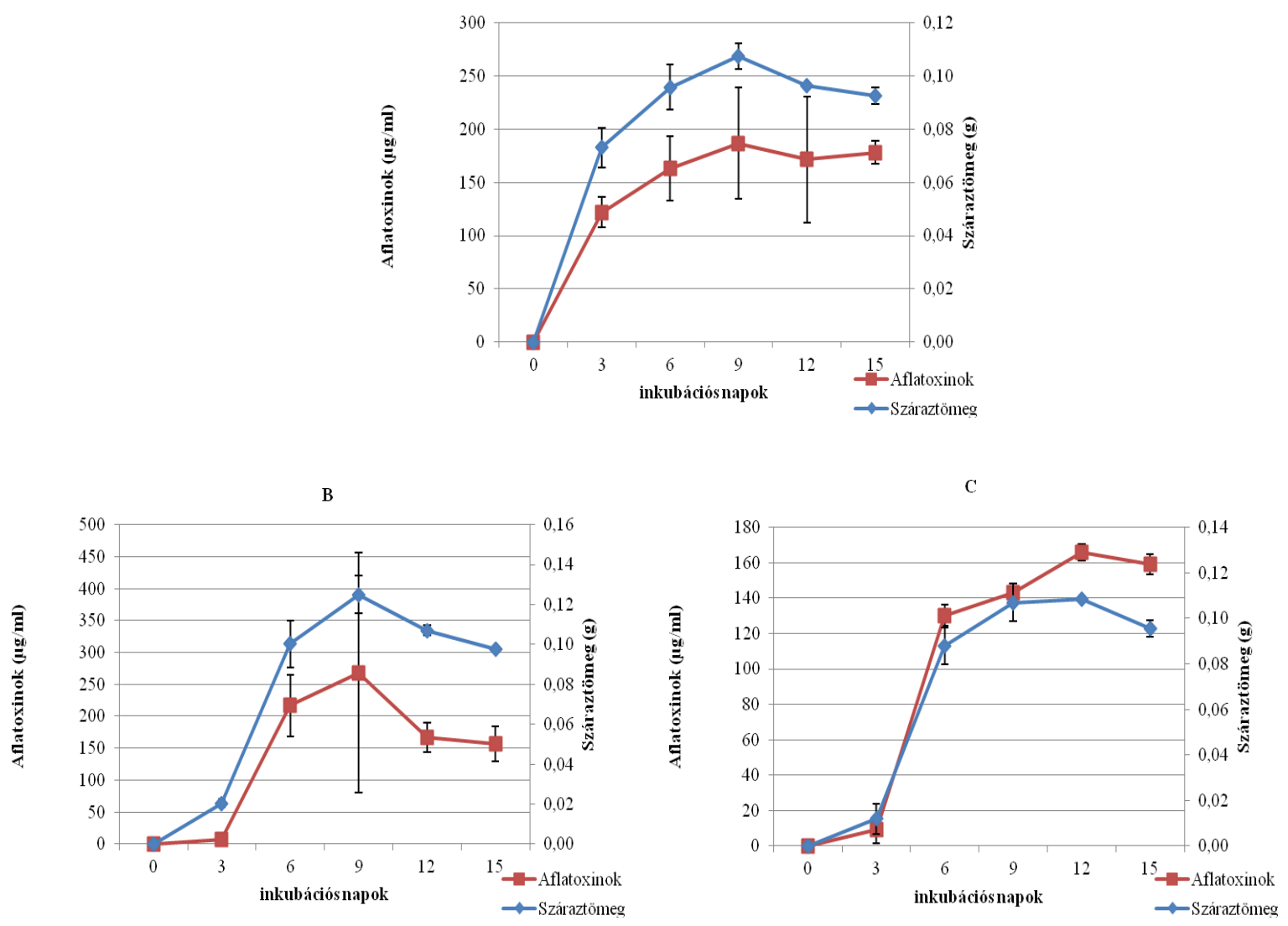

D
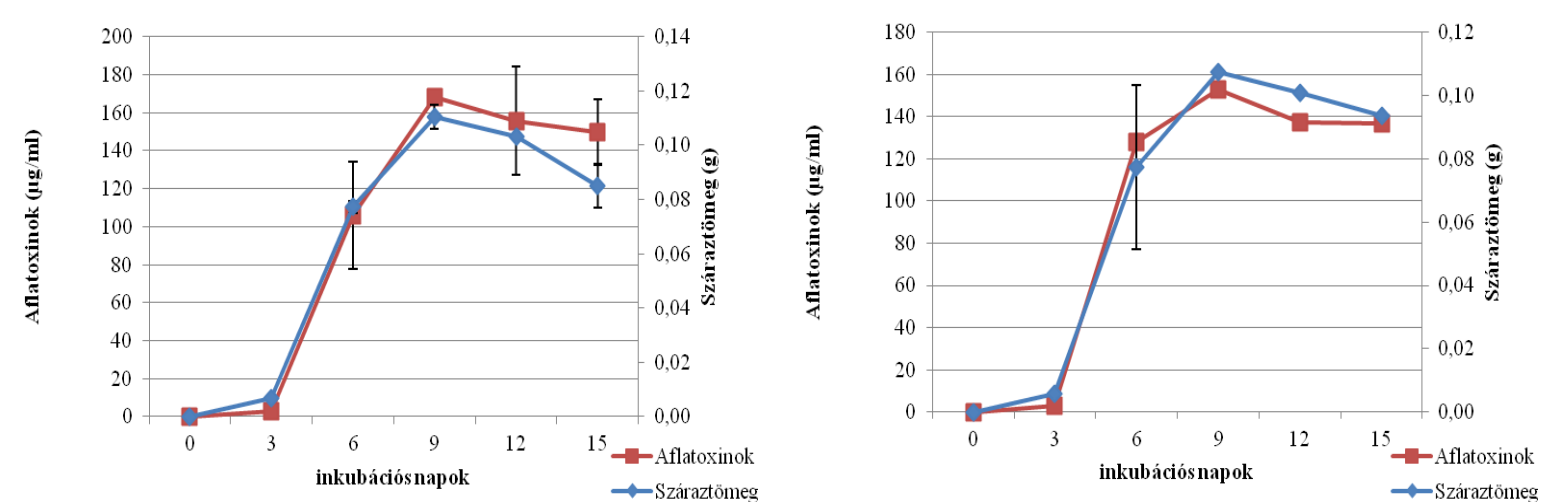

54. ábra: $A$. parasiticus által termelt aflatoxinok $(\mu \mathrm{g} / \mathrm{ml})$ valamint a telepek száraztömegének $(\mathrm{g})$ időbeni változása muskotályzsálya illóolajos kezelést követően. Alkalmazott muskotályzsálya illóolaj koncentrációk a légtérben: A: kontroll minták, B: $0,05 \mathrm{mg} / \mathrm{cm}^{3}, \mathrm{C}: 0,105 \mathrm{mg} / \mathrm{cm}^{3}, \mathrm{D}: 0,21 \mathrm{mg} / \mathrm{cm}^{3}, \mathrm{E}: 0,42 \mathrm{mg} / \mathrm{cm}^{3}$

Muskotályzsálya illóolaj alkalmazásakor azt találtuk, hogy az illóolaj koncentráció növekedése az inkubáció kezdetén (3. nap mérési eredményei) a mintákban egyre növekvő 
AFB1 és csökkenő AFG1 arányt eredményezett. A kontroll mintákhoz képest lecsökkent az AFG2 toxinok aránya is.

A 6. naptól kezdődően az inkubációs időtől függetlenül, de az illóolaj koncentrációtól függő módon az AFG1 arány csökkent, az AFB1 arány pedig növekedett a mért mintákban (55. ábra).

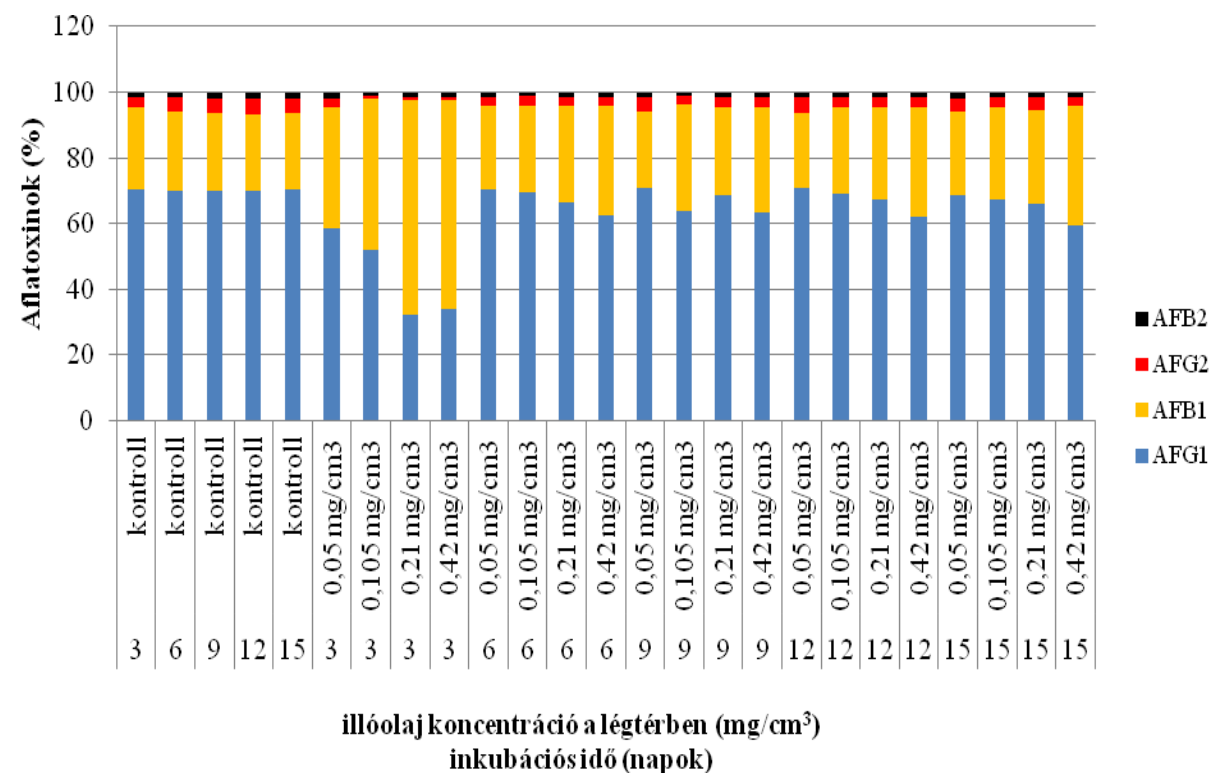

55. ábra: A. parasiticus által termelt aflatoxinok aránya (\%) a légtérben különböző koncentrációkban alkalmazott muskotályzsálya illóolajos kezelést követően, az inkubációs idő figyelembe vételével.

A folyadéktenyészetben végrehajtott kísérleteink eredményeképpen leírható, hogy a kontroll minták esetében a micéliumtömeg a 6., az aflatoxinok mennyisége a 12. napig növekvő, majd ezután csökkenő tendenciát mutatott. A kezelt mintáknál a micéliumok száraztömege általában a 9. napig nőtt, majd csökkenő szakaszba lépett. Ennek oka a sejteket érintő autolízis lehet.

A gombák autolízise az öregedö hifák önbontásának természetes folyamata, amely a hidrolitikus enzimek (kitinázok, proteázok, glükanázok) hatására jelentkezik. Ez a sejtfalszerkezet, valamint a sejtszervecskék károsodását idézi elő (White és mtsai. 2002). Általánosan elfogadott, hogy a tápanyaghiány az autolízis megindulásához vezethet. A tápanyaghiányra a sejtek proteáz aktivitással válaszolnak, ami az autolízis egyik fontos eleme (McIntyre és mtsai. 2000).

Az autolízis energiaigényes és de novo fehérjeszintézis függő folyamat. A sejtekben a reaktív oxigén származékok (ROS) feldúsulása autolízishez vezet, ami csökkenő gomba 
száraztömeget eredményez, valamint növekvő extracelluláris kitináz aktivitással jár. (Emri és mtsai. 2004).

\subsection{A. parasiticus tenyésztése búza szubsztráton, az aflatoxin termelés vizsgálata}

Az A. parasiticus aflatoxin-termelését annak természetes szubsztrátján is detektálni kívántuk. Az alkalmazott kísérleti módszer modellezte a rosszul betárolt, befülledt, benedvesedett búzát. Ez nagyüzemi körülmények között nagy problémát jelenthet, különösen azokban az országokban, ahol kénytelenek mellőzni a moder, szellőztethető silókat. A gabonák penészesedésével, átnedvesedésével nem megfelelő körülmények között számolni kell.

\subsubsection{Búzaminták vízaktivitás értékei}

Száraz búza esetén a vízaktivitás $0,36 \pm 0,01$, míg nedves búza esetén $0,92 \pm 0,00$ volt. A mikroorganizmusok többsége $\mathrm{a}_{\mathrm{w}}$ 0,75 felett már képes a szaporodásra, tehát az elért vízaktivitás megfelelőnek bizonyult az $A$. parasiticus szaporodásához.

\subsubsection{Az A. parasiticus által termelt aflatoxinok detektálása az illóolajos kezelések hatására}

\subsubsection{Boróka illóolajos kezelés hatása}

Az 5. napi, kezeletlen kontroll mintákhoz képest a boróka illóolaj $0,21 \mathrm{mg} / \mathrm{cm}^{3}$ és 0,42 $\mathrm{mg} / \mathrm{cm}^{3}$ koncentrációban történő alkalmazása szignifikánsan $(\mathrm{P} \leq 0,05)$ csökkentette az $A$. parasiticus összes aflatoxin termelését az inkubáció 5. napjára.

Az inkubációs idő növelésével, a 10. napra a kontroll minták aflatoxin tartalma is szignifikánsan csökkent $(\mathrm{P} \leq 0,01)$. A boróka illóolajjal kezelt mintákban a csökkenés kisebb mértékü volt a 10. napra, mint a kezeletlen, kontroll minták esetén. A hosszabb, 10 napos inkubácinál az illóolajos gőztér alkalmazása magasabb aflatoxin tartalmat eredményezett a kontroll mintákhoz képes. Ez azonban nem jelent szignifikáns különbséget $(\mathrm{P}>0,05)(56$. ábra). 


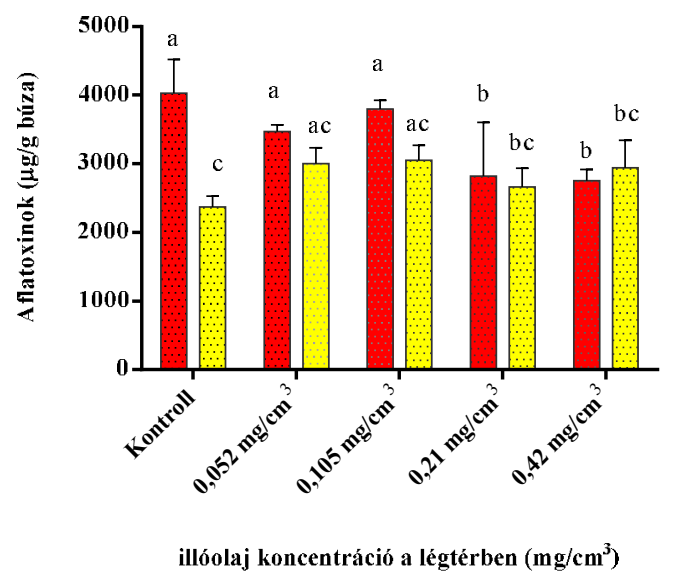

56. ábra: A. parasiticus törzs aflatoxin termelése búza szubsztráton, borókaolajos kezelést követően (piros szín: 5 napos minták, sárga szín: 10 napos minták). Az oszlopok tetején található különböző betük szignifikáns eltérést $(\mathrm{P}<0,05)$ jeleznek, míg azonos betük esetében az eltérés nem volt szignifikáns.

A Boróka illóolaj légtérben történő alkalmazásánál, egyik koncentrációnál sem tapasztaltunk szignifikáns változást az egyes komponensek arányában (57. ábra) az azonos időperiódusokat vizsgálva (5 napos, illetve 10 napos minták), a kontrollokhoz képest. Ugyanakkor, a hosszabb (10 napos) inkubációs periódus alkalmazásakor szignifikánsan csökkent az AFG1 aránya a rövidebb (5 napos) inkubációhoz képest mind a kontrolok, mind a $0,21 \mathrm{mg} / \mathrm{cm}^{3}$ koncentrációjú borókaolajjal kezelt minták esetén. Ugyanezen koncentrációknál az AFB1 arány szignifikáns növekedése volt tapasztalható aolajos kezelés esetén és az AFB1 arány szignifikáns növelésére $(\mathrm{P} \leq 0,05)$.

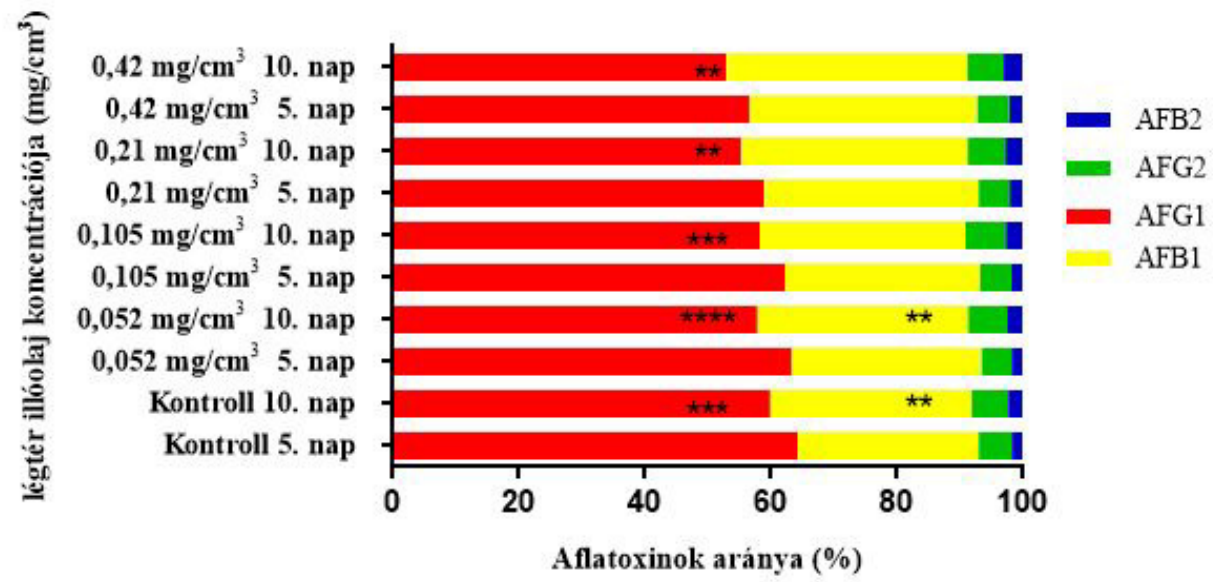

57. ábra: Aflatoxinok aránya $A$. parasiticus esetén, búza szubsztráton, boróka illóolajos kezelést követően. Az oszlopokban található jelölések ( $* \mathrm{P}<0,05 ; * * \mathrm{P} \leq 0,01 ; * * * \mathrm{P} \leq 0,001)$ szignifikáns eltérést jeleznek az 5 , illetve 10 napos minták összehasonlítása esetén, azonos illóolaj koncentrációknál. 


\subsubsection{Citrom illóolajos kezelés hatása}

A légtér citrom illóolaj koncentrációjának növelése nem eredményezett szignifikáns különbséget a kontroll mintákhoz képest sem az inkubáció 5., sem annak 10. napján. A 10. napra a mintákban az összes aflatoxin tartalom kismértékü, nem szignifikáns $(P>0,05)$ csökkenését tapasztaltuk a kontrollhoz képest (58. ábra).

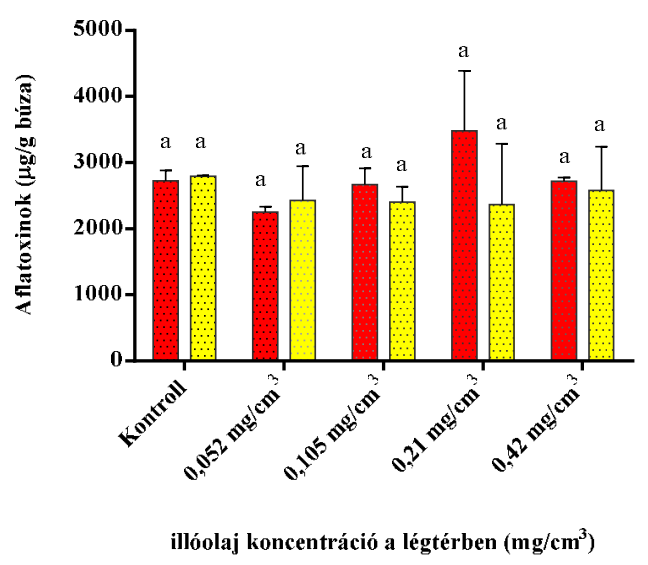

58. ábra: A parasiticus törzs aflatoxin termelése búza szubsztráton, citrom illóolajos kezelést követően (piros szín: 5 napos minták, sárga szín: 10 napos minták). Az oszlopok tetején található eltérő betük szignifikáns eltérést, az azonos betük nem szignifikáns eltérést jeleznek $(\mathrm{P}<0,05)$.

A hosszabb inkubációs periódus nem okozott szignifikáns változást az 5. és a 10. napos mintákat összehasonlítva egyik aflatoxin komponens arányában sem, a kontroll és a különböző citrom illóolaj koncentrációkkal kezelt minták esetén.

Ugyanakkor, az inkubáció 10. napján szignifikáns csökkenést tapasztaltunk a termelt AFB1 arányában a 10. napi kontrollhoz képest a 0,105 és $0,21 \mathrm{mg} / \mathrm{cm}^{3}$ citrom illóolaj koncentrációk alkalmazása esetén $(\mathrm{P} \leq 0,05)$ (59. ábra).

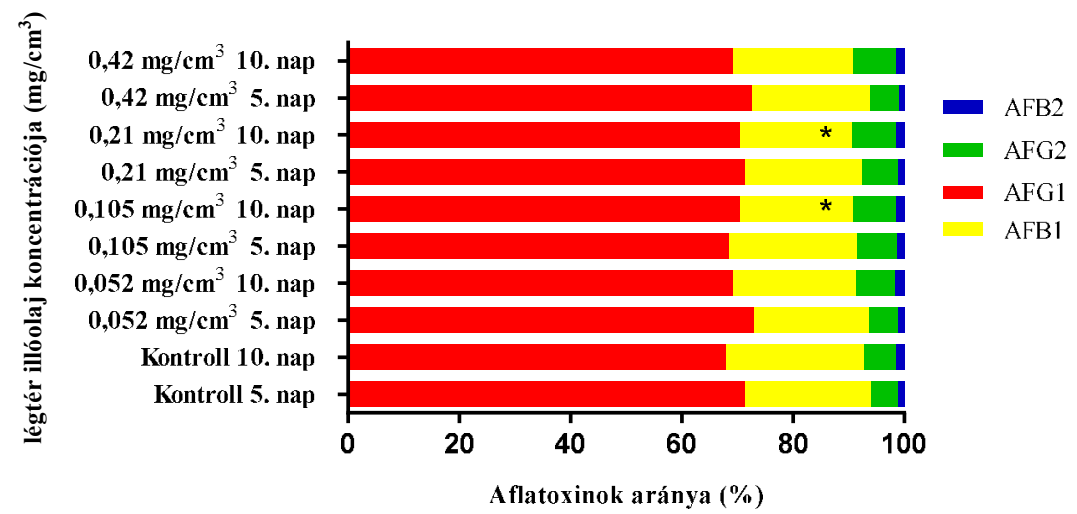

59. ábra: Aflatoxinok aránya $A$. parasiticus esetén, búza szubsztráton, citrom illóolajos kezelést követően. Az oszlopokban található jelölések $(* \quad \mathrm{P}<0,05)$ szignifikáns eltérést jeleznek az azonos időintervallúmú inkubációk kontroll mintáihoz képest. 


\subsubsection{Fahéj illóolajos kezelés hatása}

A fahéjolaj a legnagyobb koncentrációban már az 5. napon szignifikánsan csökkentette az aflatoxinok mennyiségét $(\mathrm{P} \leq 0,01)$ (60. ábra). A 10. napon minden illóolaj koncentráció alkalmazása szignifikáns csökkenést eredményezett.

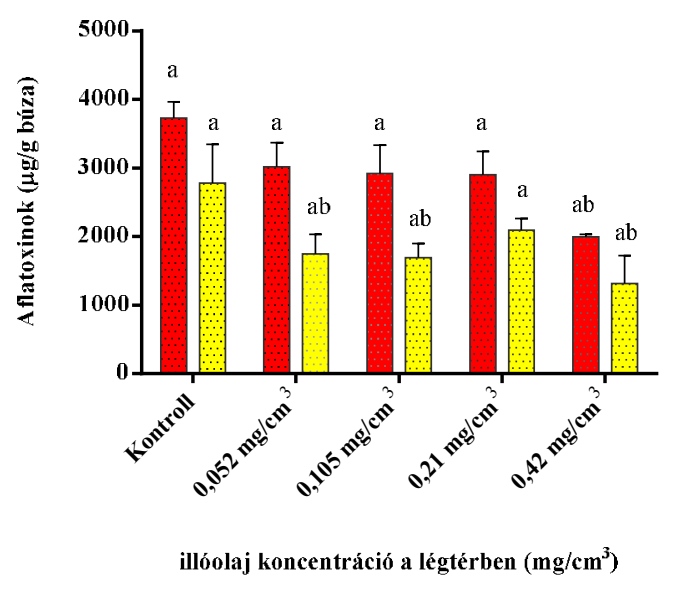

60. ábra: A parasiticus törzs aflatoxin termelése búza szubsztráton, fahéjolajos kezelést követően (piros szín: 5 napos minták, sárga szín: 10 napos minták). Az oszlopok tetején található különböző betük szignifikáns eltérést $(\mathrm{P}<0,05)$ jeleznek, míg azonos betük esetében az eltérés nem volt szignifikáns.

Az inkubációs idő növelésével szignifikánsan csökkent a termelt AFG1 aránya a kontroll, illetve a $0,105,0,21$ és $0,42 \mathrm{mg} / \mathrm{cm}^{3}$ fahéj illóolaj koncentrációk alkalmazásánál $(\mathrm{P} \leq 0,0001)$. Az AFB1 aránya szignifikáns növekedést mutatott a 10. napon a kontroll, valamint a $0,42 \mathrm{mg} / \mathrm{cm}^{3}(\mathrm{P} \leq 0,0001)$ fahéj illóolaj koncentráció alkalmazása esetén. Az AFG2 és az AFB2 arányaiban nem volt kimutatható szignifikáns eltérés az 5. és 10. napi minták összehasonlításakor, továbbá az alkalmazott illóolaj koncentrációk alkalmazása sem eredményezett szignifikáns eltérést a kontrolokhoz viszonyítva az azonos időperiódusokban (61. ábra). 


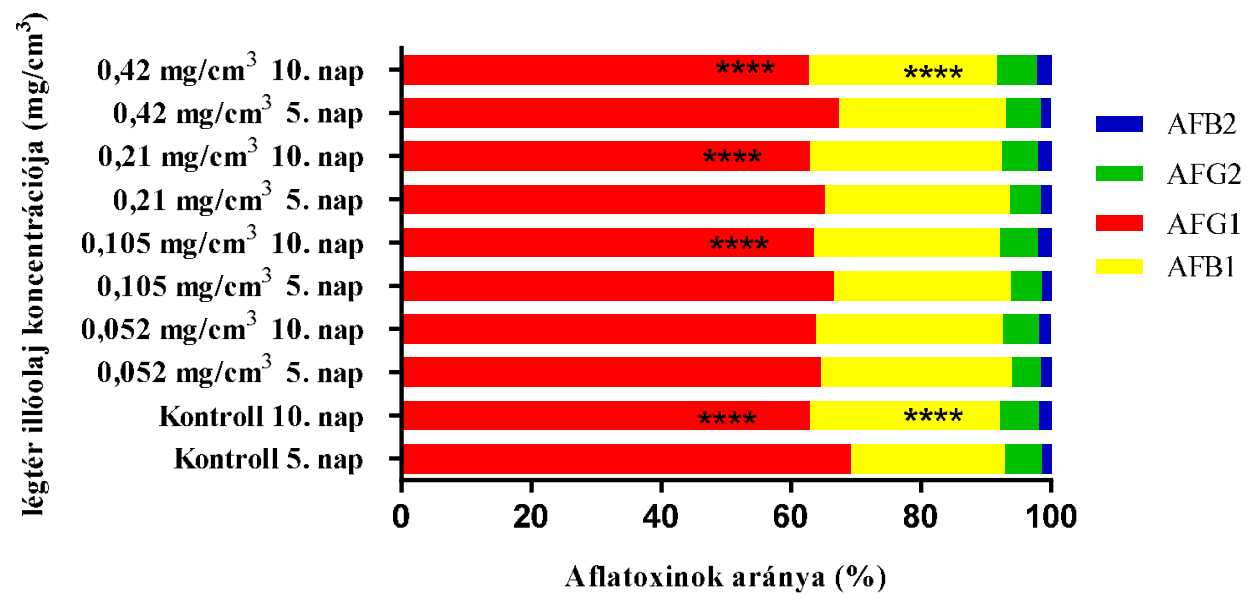

61. ábra: Aflatoxinok aránya $A$. parasiticus esetén, búza szubsztráton, fahéj illóolajos kezelést követően. Az oszlopokban található jelölések $(* * * * \mathrm{P} \leq 0,0001)$ szignifikáns eltérést jeleznek az 5, illetve 10 napos minták összehasonlítása esetén, azonos illóolaj koncentrációknál.

\subsubsection{Majoránna illóolajos kezelés hatása}

A majoránna illóolajjal való kezelés serkentőleg hatott az aflatoxin termelésre mind a rövidebb (5 napos), mind a hosszabb (10 napos) inkubáció esetén. Rövidebb inkubációnál a nagyobb mennyiségü illóolaj jelenléte $\left(0,42 \mathrm{mg} / \mathrm{cm}^{3}\right)$, míg hosszabb inkubációnál a kisebb mennyiség $\left(0,052 \mathrm{mg} / \mathrm{cm}^{3}\right)$ serkentette leginkább az aflatoxin termelődést a kontrolokhoz képest. Szignifikáns különbséget $(\mathrm{P} \leq 0,05)$ az 5 napos és 10 napos minták összehasonlításakor azonban csak egyedül a $0,42 \mathrm{mg} / \mathrm{cm}^{3}$ illóolaj koncentráció mellett tapasztaltunk (62. ábra).

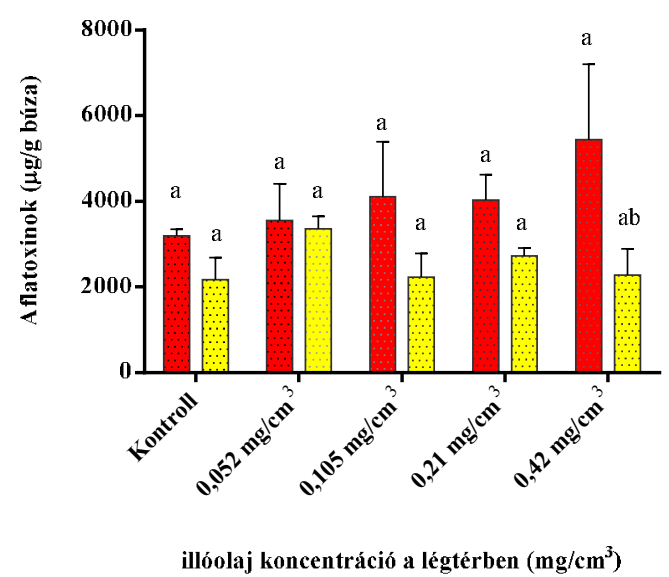

62. ábra: $A$. parasiticus törzs aflatoxin termelése búza szubsztráton, majoránnaolajos kezelést követően (piros szín: 5 napos minták, sárga szín: 10 napos minták). Az oszlopok tetején található különböző betük szignifikáns eltérést $(\mathrm{P}<0,05)$ jeleznek, míg azonos betük esetében az eltérés nem volt szignifikáns 
Az inkubációs idő növelésével az AFG1 toxin aránya szignifikánsan csökkent a kontroll, illetve az összes majoránna illóolaj koncentráció alkalmazásakor. Emellett az AFB1 toxin aránya szignifikánsan növekedett a kontrollok, valamint a $0,052 \mathrm{mg} / \mathrm{cm}^{3}$ illóolajjal kezelt 5 és 10 napos minták összehasonlításakor $(\mathrm{P} \leq 0,01)$ (69. ábra). Az AFG2 és az AFB2 arányaiban azonban nem volt kimutatható szignifikáns eltérés az 5 és 10 napos minták összehasonlításakor, továbbá az alkalmazott illóolaj koncentrációk sem eredményeztek szignifikáns eltérést a kontrollokhoz viszonyítva az azonos időperiódusokban (63. ábra).

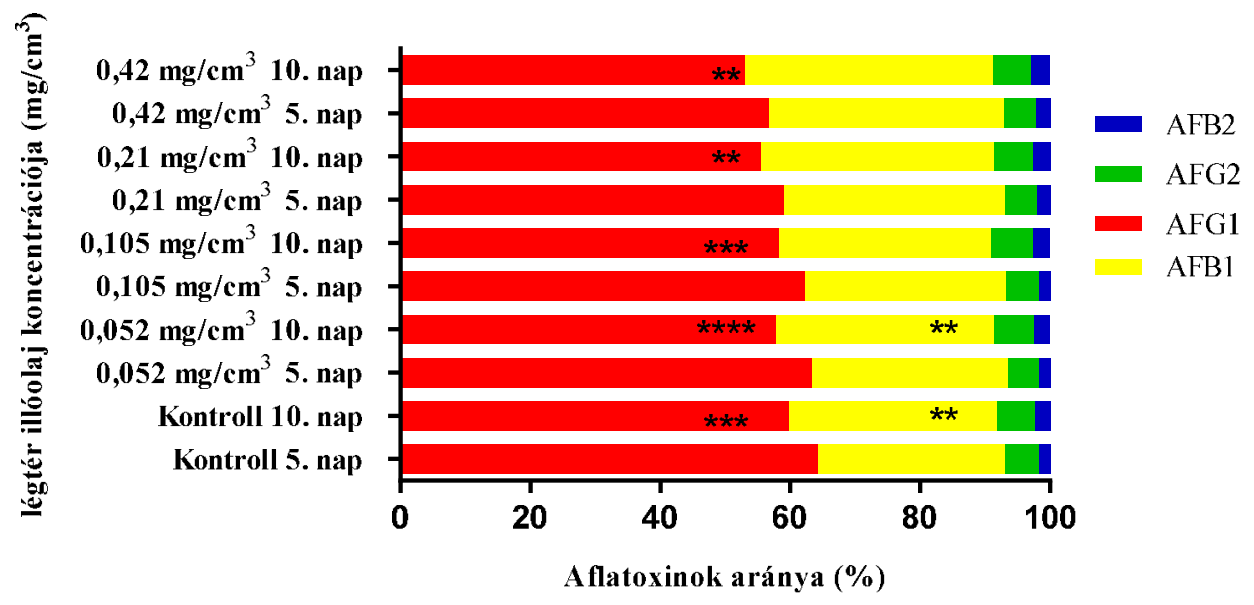

63. ábra: Aflatoxinok aránya $A$. parasiticus esetén, búza szubsztráton, majoránna illóolajos kezelést követően. Az oszlopokban található jelölések (** $\mathrm{P} \leq 0,01 ; * * * \quad \mathrm{P} \leq 0,001$; **** $\mathrm{P} \leq 0,0001)$ szignifikáns eltérést jeleznek az 5, illetve 10 napos minták összehasonlítása esetén, azonos illóolaj koncentrációknál

\subsubsection{Muskotályzsálya illóolajos kezelés hatása}

A muskotályzsálya illóolaj kis koncentrációban történő alkalmazása során mindkét inkubációs idő végére az aflatoxin tartalom kismértékben, nem szignifikánsan $(\mathrm{P}>0,05)$ növekedett a kontroll mintákhoz képest (64. ábra). Az 5. naphoz képest, a 10. napra, a 0,42 $\mathrm{mg} / \mathrm{cm}^{3}$ illóolaj koncentrációt kivéve, az aflatoxin mennyisége szignifikánsan csökkent $(\mathrm{P} \leq 0,001)$. 


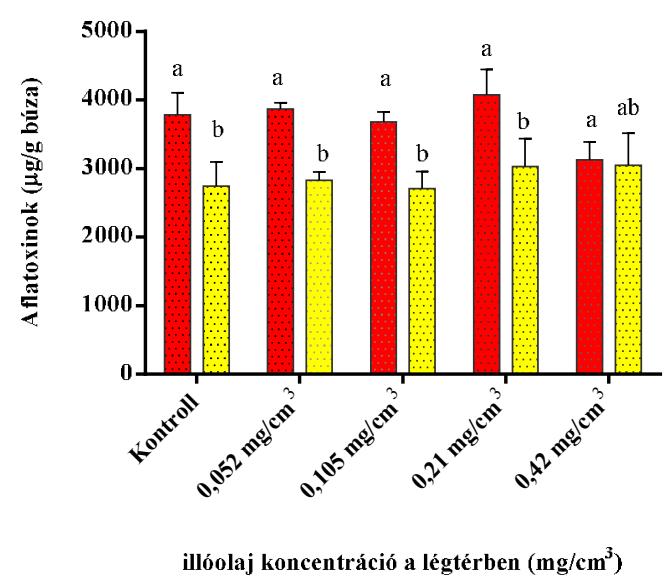

64. ábra: A. parasiticus törzs aflatoxin termelése búza szubsztráton, muskotályzsálya olajos kezelést követően (piros szín: 5 napos minták, sárga szín: 10 napos minták). Az oszlopok tetején található különböző betük szignifikáns eltérést $(\mathrm{P}<0,05)$ jeleznek, míg azonos betük esetében az eltérés nem volt szignifikáns.

Muskotályzsálya illóolaj alkalmazásakor főként az AFG1 arányában tapasztaltunk szignifikáns csökkenést az inkubációs idő növelésével a kontrollnál $(\mathrm{P} \leq 0,0001)$, valamint a $0,052 \mathrm{mg} / \mathrm{cm}^{3}(\mathrm{P} \leq 0,01)$ a $0,105 \mathrm{mg} / \mathrm{cm}^{3}(\mathrm{P} \leq 0,05)$ és a $0,42 \mathrm{mg} / \mathrm{cm}^{3}(\mathrm{P} \leq 0,0001)$ koncentrációk alkalmazásakor. Az AFB1 toxin aránya csupán $0,21 \mathrm{mg} / \mathrm{cm}^{3}$ illóolaj koncentrációnál változott szignifikánsan a 10. napra az 5. naphoz képest $(\mathrm{P} \leq 0,05)$ (65. ábra).

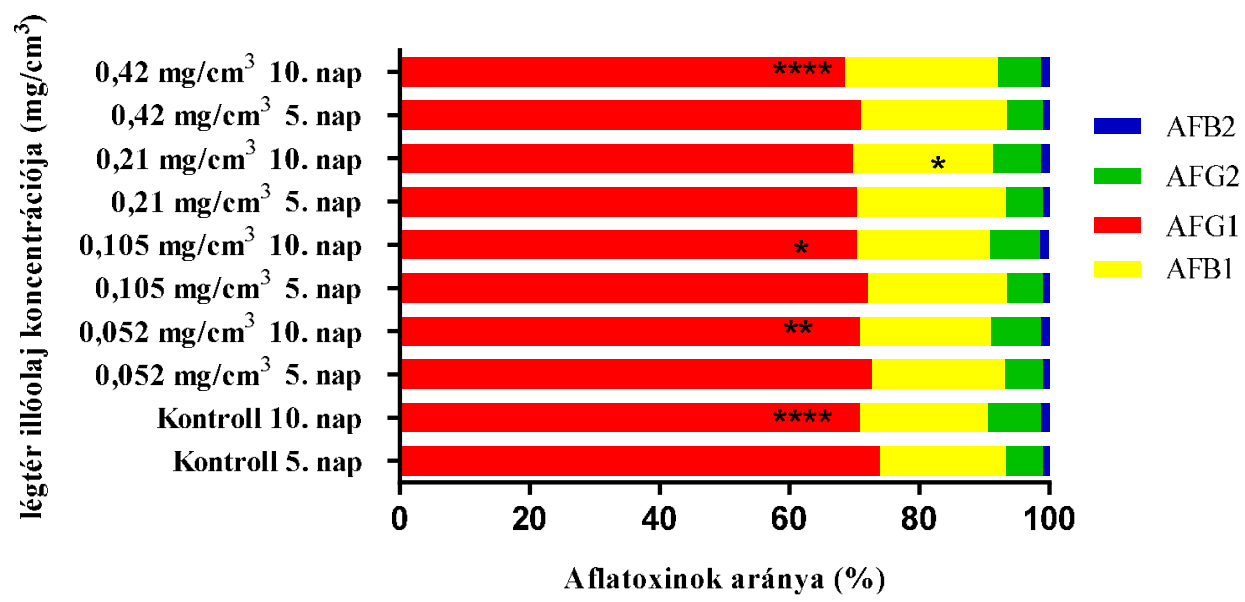

65. ábra: Aflatoxinok aránya $A$. parasiticus esetén, búza szubsztráton, muskotályzsálya illóolajos kezelést követően. Az oszlopokban található jelölések $*^{*} \mathrm{P} \leq 0,05$; ** $\mathrm{P} \leq 0,01$; **** $\mathrm{P} \leq 0,0001)$ szignifikáns eltérést jeleznek az 5, illetve 10 napos minták összehasonlítása esetén, azonos illóolaj koncentrációknál. 


\subsection{Illóolajok hatása a fonalasgombák morfológiájára}

Kísérleteink során vizsgáltuk az illóolajok hatását elektronmikroszkópos, fénymikroszkópos valamint vizuális vizsgálatokkal a fonalasgombák morfológiájára.

\subsubsection{Elektronmikroszkópos vizsgálatok eredménye}

Elektronmikroszkóp segítségével a $F$. culmorum morfológiai változásait vizsgáltuk, amikor a tenyésztés agar-hígításos módszerrel történt. Az illóolajat a táptalajba kevertük bele. A SEM fotók (66. és 67. ábra) jól mutatják, hogy a $F$. culmorum esetében a majoránna illóolajos kezelés hatására a hifák elvékonyodtak. A sejtek falán repedések találhatók, a citoplazma tartalom kiszivárgott és láthatóvá vált.

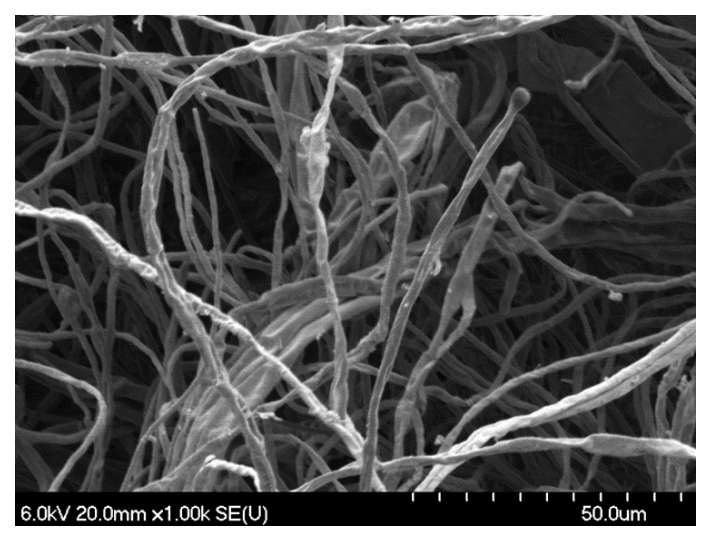

66. ábra: F. culmorum hifák kezeletlen, kontroll telep

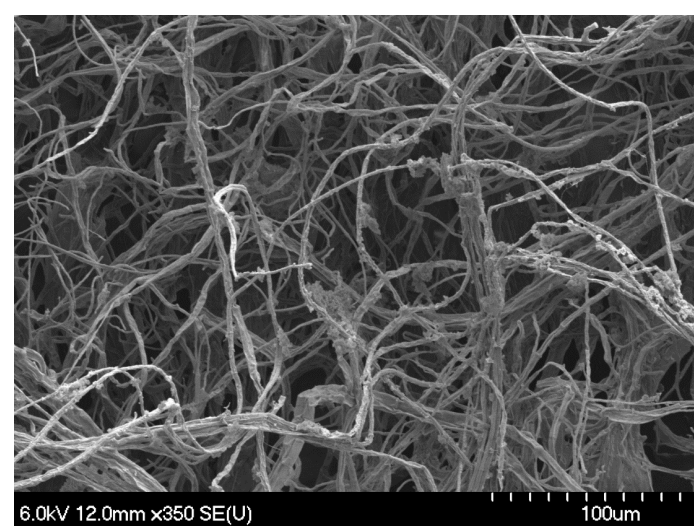

67. ábra: $F$. culmorum hifák majoránna illóolajos kezelést követöen $\left(1,25 \mathrm{mg} / \mathrm{cm}^{3}\right)$

Lambert és munkatársai (2001) leírták, hogy az illóolajok képesek megváltoztatni a membránok áteresztőképességét, ami az antimikrobiális mechanizmus egyik fő faktora. A megnövekedett ozmotikus nyomás miatt gyengül a sejtfal, a membrán áthatolhatóvá válásával a citoplazma tartalom csökken és a mikrokonídiumok ellaposodása is tapasztalható (Carson és mtsai. 2002, Yamamoto-Ribeiro és mtsai. 2013). 


\subsubsection{Morfológiai változások folyadékközegben történö tenyésztés esetén}

Folyadéktenyészetekben, illóolaj tartalmú gőztérben vizsgáltuk az $A$. nomius és az $A$. parasiticus törzsek morfológiájában bekövetkező változásokat. Mindegyik illóolaj esetén azt tapasztaltuk, hogy a légtér illóolaj koncentrációjának növelésével megváltozott a spórák színe (68. és 69. ábrák).

A legtöbb fonlasgomba esetén az aszexuális fejlödés a jellemző, míg a szexuális szaporodás kevésbé általános (O’Gorman és mtsai. 2009). A konídiumok aszexuális spórák, melyek közvetlenül képződhetnek a hifákból vagy indirekt módon a filaidokból (Adams és mtsai. 1998). Bayram és Braus (2011) tanulmányukban rámutattak arra, hogy a másodlagos metabolitok képződése, közös szabályozási folyamatokon keresztül, kapcsolatban lehet a fonalasgombák fejlődésével, válaszul a külső biotikus vagy abiotikus tényezőkre. A stressz faktorok jelenléte, tápanyagok, oxigén elérhetősége morfológiai- és másodlagos anyagcsere változásokhoz vezethetnek.
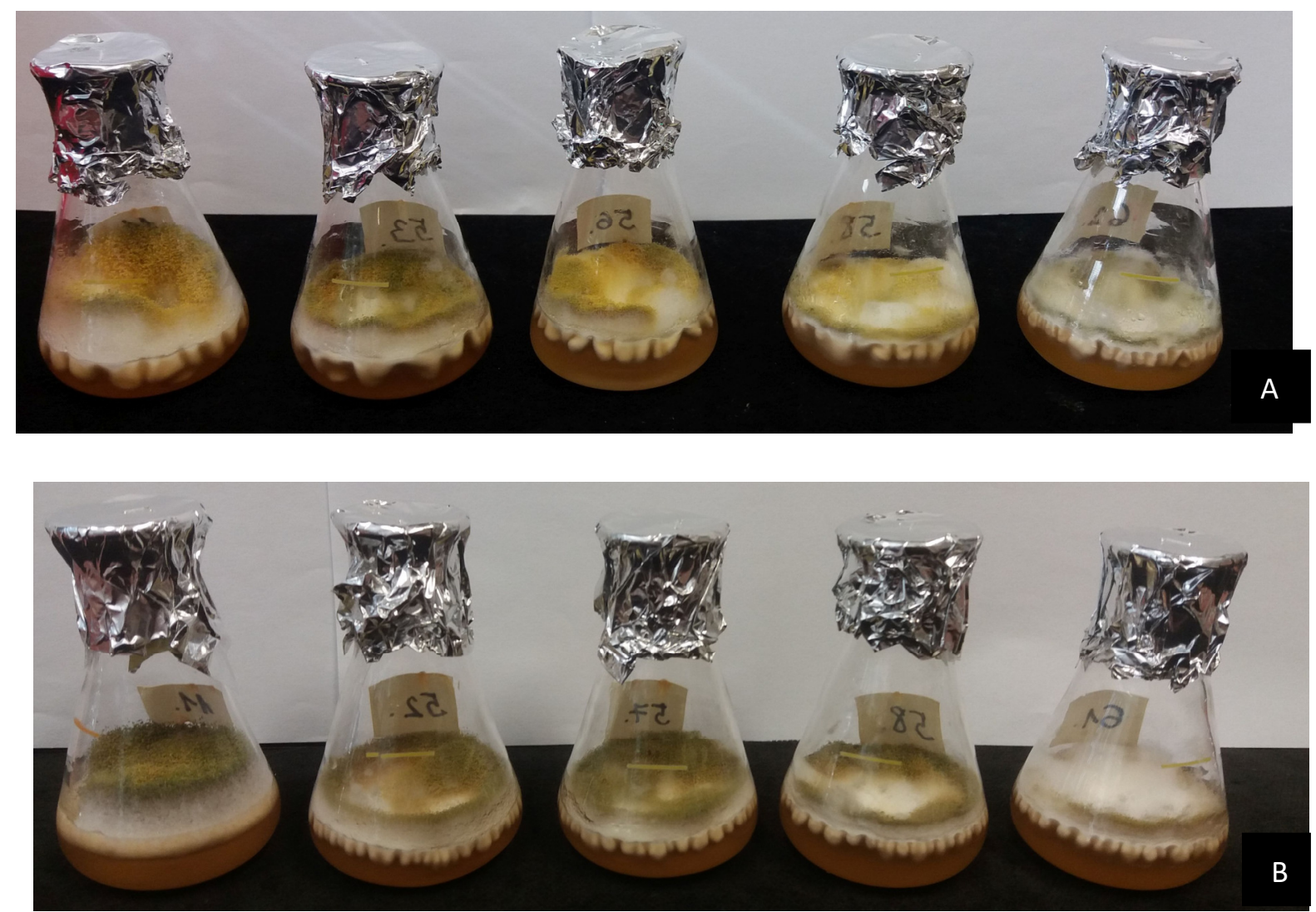

68. ábra: A. nomius telepek folyadéktenyészetben, majoránna (A) és muskotályzsálya (B) illóolajjal történő kezelést követően, az inkubáció 12. napján. A lombikok légtérfogatra vonatkoztatott illóolaj koncentrációja (balról jobbra haladva): $0 \mathrm{mg} / \mathrm{cm}^{3}$ (kontroll), 0,052 $\mathrm{mg} / \mathrm{cm}^{3}, 0,105 \mathrm{mg} / \mathrm{cm}^{3}, 0,21 \mathrm{mg} / \mathrm{cm}^{3}$ és $0,42 \mathrm{mg} / \mathrm{cm}^{3}$. 
$\mathrm{Az}$ A. nomius és az A. parasiticus törzseknél a légtér növekvő illóolaj koncentrációja a legtöbb illóolaj alkalmazása esetén csökkent spóraképzést eredményezett.
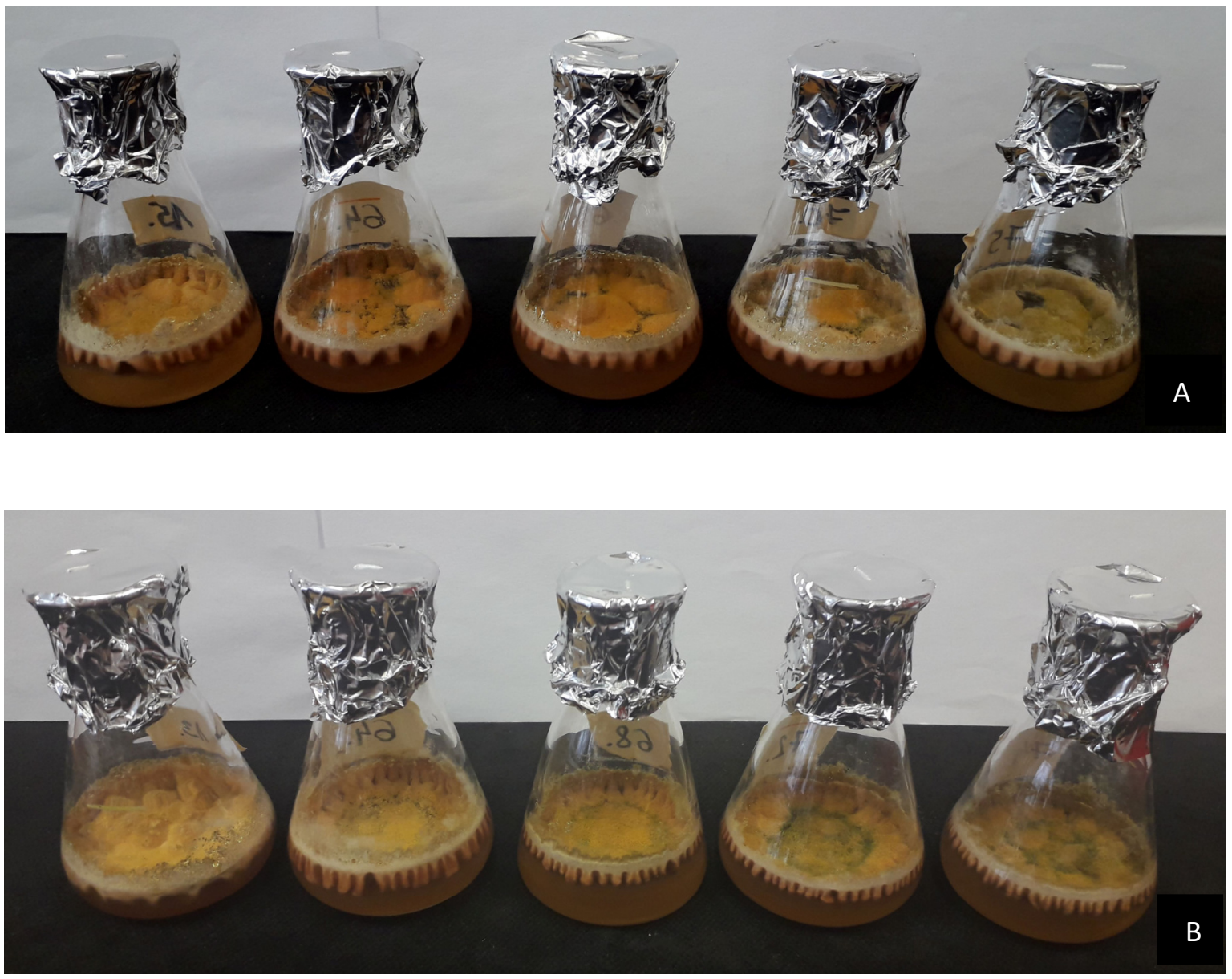

69. ábra: A parasiticus telepek majoránna (A) és muskotályzsálya (B) illóolajjal történő kezelést követően, az inkubáció 15 . napján. A lombikok légtérfogatra vonatkoztatott illóolaj koncentrációja (balról jobbra haladva): $0 \mathrm{mg} / \mathrm{cm}^{3}$ (kontroll), 0,052 mg/ $\mathrm{cm}^{3}, 0,105 \mathrm{mg} / \mathrm{cm}^{3}$, $0,21 \mathrm{mg} / \mathrm{cm}^{3}$ és $0,42 \mathrm{mg} / \mathrm{cm}^{3}$. 
Kísérleteink során, egyetlen esetben, a fahéjolaj alkalmazása során tapasztaltuk, hogy az A. nomius és az A. parasiticus folyadéktenyészetekben megnyúltak a hifák (70. ábra).
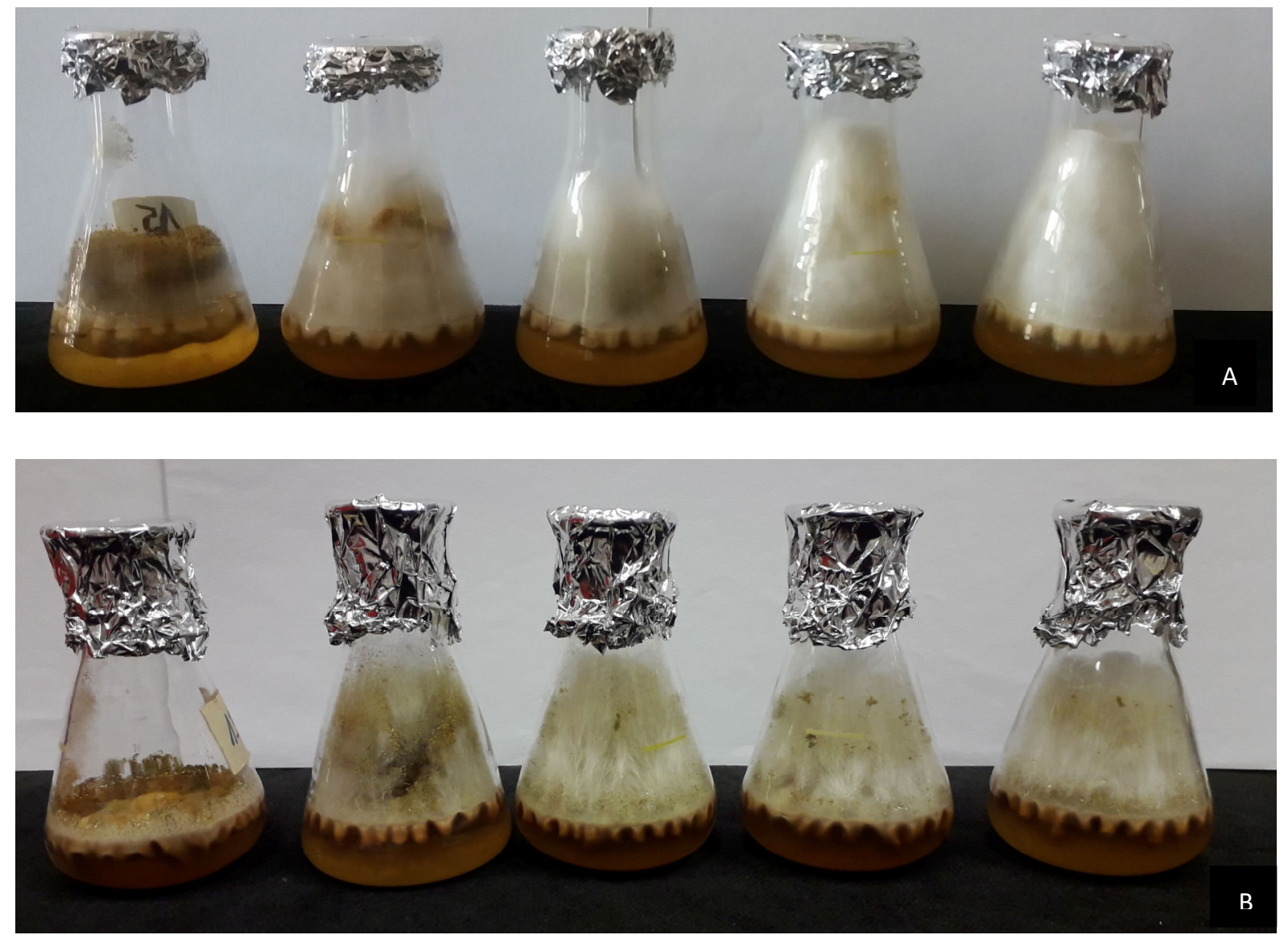

70. ábra: A. nomius (A) és A. parasiticus (B) telepek fahéjolajjal történő kezelést követően, az inkubáció 15. napján. A lombikok légtérfogatra vonatkoztatott illóolaj koncentrációja (balról jobbra haladva): $0 \mathrm{mg} / \mathrm{cm}^{3}$ (kontroll), $0,052 \mathrm{mg} / \mathrm{cm}^{3}, 0,105 \mathrm{mg} / \mathrm{cm}^{3}, 0,21 \mathrm{mg} / \mathrm{cm}^{3}$ és $0,42 \mathrm{mg} / \mathrm{cm}^{3}$. 


\section{6. ÖSSZEFOGLALÁS}

Munkánk fó célja az volt, hogy megvizsgáljuk öt kiválasztott, szubletális koncentrációban alkalmazott illóolaj hatását néhány, mikotoxintermelő Aspergillus és Fusarium faj növekedésére és toxin termelésére. Az A. nomius és A. parasiticus törzsek aflatoxintermelését illóolajat tartalmazó gőztérben vizsgáltuk. Eredményeinkből az alábbi következtetésekre jutottunk:

\section{1) A tesztelt illóolajok a különböző fonalasgomba fajok növekedésére,} koncentrációtól függően különböző hatást gyakoroltak.

Az öt tesztelt illóolaj közül a fonalasgombák növekedésének visszaszorításában legkevésbé hatékonynak a főként monoterpénekből álló citrom és a boróka illóolaj bizonyult. A legjobb eredményeket az Aspergillus és a Fusarium fajok esetében is a fahéj és majoránna illóolajjal értük el. A fahéjolaj erős antifungális hatása a benne található fahéjaldehidnek tulajdonítható. A táptalajban történő, igen kis koncentrációjú $\left(0,30-0,65 \mathrm{mg} / \mathrm{cm}^{3}\right)$ alkalmazása teljes növekedésgátlást okozott valamennyi vizsgált Fusarium izolátum esetén. A légtérben alkalmazott majoránna és muskotályzsálya illóolajok, különösen a nagyobb koncentrációkban $\left(0,42 \mathrm{mg} / \mathrm{cm}^{3}\right)$, hatékonynak bizonyultak a fonalasgombák növekedésgátlásában.

\section{2) Az illóolajok morfológiai változás okoztak a fonalasgombáknál, szilárd és folyékony közegben történő tenyésztés során is.}

Az illóolajos kezelés hatására a $F$. culmorum hifái elvékonyodtak, a sejtfal károsodott, a citoplazma tartalom kiszivárgott és láthatóvá vált. Valamennyi illóolaj légtérben történő alkalmazása a spórák színének megváltozását eredményezte. A legtöbb illóolaj esetében, az $A$. nomius és az A. parasiticus törzseknél a légtér növekvő illóolaj koncentrációja csökkent spóraképződést eredményezett. A táplevesben tenyésztett $A$. nomius és $A$. parasiticus esetében a fahéj illóolaj alkalmazása a hifák megnyúlását eredményezte.

\section{3) Az illóolajok különböző tenyésztési körülmények között különbözőképpen hatottak az $A$. parasiticus és az $A$. nomius aflatoxin termelésére.}

A szilárd táptalajon tenyésztett $A$. parasiticus esetében a majoránna illóolaj mutatta a leghatékonyabb gátlást, mind a növekedés, mind a toxintermelés vonatkozásában. A növekedés és a spóraképzés csaknem teljesen leállt, és az aflatoxin termelés is szignifikánsan 
csökkent. Szilárd táptalajon tenyésztett fonalasgombáknál a toxintermelés akkor kezdett csökkenni, amikor a növekedésgátlás elért egy bizonyos mértéket.

$\mathrm{Az}$ Aspergillus-ok folyadéktenyészetében az aflatoxinok mennyisége és a micéliumok száraztömege kezdetben növekedést, majd egy maximum után csökkenést mutatott. Az $A$. nomius esetén az összes, a légtérben alacsony koncentrációban jelenlévő illóolaj serkentőleg hatott az aflatoxin termelésre. Hatékony gátlást a legnagyobb koncentrációban $\left(0,42 \mathrm{mg} / \mathrm{cm}^{3}\right)$ alkalmazott illóolajokkal tudtunk elérni.

Az A. parasiticus folyadéktenyészetben jóval nagyobb mennyiségben termelt aflatoxint, mint az A. nomius. Bár a növekedési kísérletekben legkevésbé hatékonynak a citrom és a boróka illóolaj mutatkozott, a folyadéktenyészetekben képesek voltak az aflatoxin termelést csökkenteni. A fahéj-, majoránna és muskotályzsálya illóolajok kisebb koncentrációban inkább serkentőleg hatottak az A. parasiticus aflatoxin termelésére.

A mintákban az AFG1 toxin jelent meg a legnagyobb mennyiségben. A legtöbb esetben az inkubációs idő előrehaladtával, illetve a koncentráció függvényében módosult a mintákban lévő aflatoxinok százalékos aránya. A fahéj, majoránna, muskotályzsálya illóolajok nagyobb, míg a citrom és a boróka illóolajok kisebb mértékü változást okoztak.

\section{4) A búza szubsztráton tenyésztett, $A$. parasiticus toxintermelésének gátlásában egyedül a fahéj illóolaj volt hatékony.}

A légtérbe vitt fahéjolaj koncentrációjának növelésével az aflatoxin termelés egyre inkább visszaszorult. A citrom és a muskotályzsálya illóolaj nem gátolta szignifikánsan az aflatoxin termelést. Majoránna illóolaj használatakor toxintermelést serkentő hatást észleltünk. A megfelelő inkubációs körülmények ellenére minden mintában kevesebb aflatoxint mértünk az inkubáció végén, mint a közepén, ami a toxinok természetes bomlása miatt következett be.

A búzán legnagyobb mennyiségben és arányban (63-73\%) az AFG1, majd az AFB1 (19-38\%) termelődött. Az inkubációs idő növekedésével az arányok változása volt jellemző.

Összehasonlítva a kontrollt, valamint a különböző koncentrációjú illóolajjal kezelt mintákat az inkubáció végére mind a kontroll, mind pedig a kezelt mintákban az AFG1 aránya csökkent, az AFB1, AFG2, AFB2 aránya pedig növekedett. Az egyes aflatoxin komponensek arányait tekintve a legkisebb mértékü változást a citrom- és a muskotályzsálya olajjal történő kezelésnél tapasztaltuk. 
Szilárd táptalajon és a búza szubsztráton a majoránna illóolaj ellenkezőképpen viselkedett. A Petri-csészés kísérleteknél a leghatékonyabbnak a majoránna illóolaj bizonyult, mind a növekedés, mind a toxintermelés gátlásában. Búza szubsztráton viszont a kontrollhoz képest a majoránna olaj megnövelte az aflatoxinok mennyiségét. A búza szubsztráton a fahéj illóolaj volt a leghatékonyabb, szignifikánsan gátolta a toxintermelést, míg a Petri csészés kísérletnél a fahéjolaj hatása nem volt jelentős.

Kísérleteink eredménye kapcsán hangsúlyozandó, hogy az illóolajok hatékonysága a különböző módszereknél eltérő volt. Az A. parasiticus-t vizsgálva, folyadéktenyészetben leghatékonyabbnak a citrom és a boróka illóolaj mutatkozott, a búza szubsztráton a fahéj, míg szilárd táptalajon a majoránna illóolaj tudta a leghatékonyabban visszaszorítani az aflatoxin termelést. Ezt a jelenséget valószínüleg az illóolaj komponensek és a tápközeg-gomba közti abszorpciós-deszorpciós viszonyok okozzák.

Az illóolajok antifungális hatása esetében koncentrációfüggést is kimutattunk. A kapott eredmények arra mutatnak rá, hogy az illóolajok stresszfaktorként lehetnek jelen, így növelhetik a fonalasgombák aflatoxin termelését, különösen alacsony koncentrációban. Az illóolajok oxidatív stresszt okozhatnak, amelyről már tudott, hogy növeli a toxin szintézist. Az aflatoxin szintézis gátlásában fontos tényező az illóolajok kémiai jellege (ami az összetevők függvénye) és az alkalmazott koncentráció, valamint a tenyésztés körülményei.

Eredményeink rámutattak arra, hogy illóolajok hatással vannak a fonalasgombák szexuális életciklusára, annak beindulására, fenntartására. Kísérleteinkben az illóolajok hatására a konidiogenezis háttérbe szorult, a konídiumok száma csökkent, ugyanakkor a fenotipikus jellegek fokozottan jelentek meg (ériális hifák növekedése, megnyúlása) gyakran fokozott másodlagos metabolit képződés (aflatoxinok) mellett.

Eredményeink alapján, az illóolajok alkalmazásakor, az alkalmazott módszer függvényében, jól kell megválasztani a koncentrációt, hogy a kívánt hatást elérjük. Kísérleti eredményeink szerint az aflatoxin termelés követte a fonalasgomba növekedését, pusztulását. Gátolt aflatoxin termelés csak gátolt fonalasgomba-növekedéssel volt elérhető. Cáfolva más szerzők állítását, az illóolajokat kellően nagy koncentrációban kell alkalmaznunk, hogy az Aspergillus nemzetségbe tartozó gombák növekedésére gyakorolt hatással együtt az aflatoxin termelésre is szignifikánsan csökkentő hatást gyakoroljanak. 


\section{SUMMARY}

The present study aimed to examine the effect of five essential oils (EOs) used in sublethal concentration on growth and toxin production of certain Aspergillus and Fusarium species. The effect on aflatoxin production of A. nomius and A. parasiticus was tested with essential oils used in vapour phase. The results of the assays performed were as follows:

\section{1.) The essential oils had dissimilar and concentration dependent effect on the} growth of moulds.

The most promissing results, both in case of Aspergillus and Fusarium species, were achieved using cinnamon and marjoram EOs, whereas juniper and lemon EOs - consisting mainly of monoterpenes as main components - were the least efficient in reducing fungal growth. Cinnamon EO, mixed to the medium at low concentrations $\left(0.30-0.65 \mathrm{mg} / \mathrm{cm}^{3}\right)$, achieved total growth inhibition of all investigated Fusarium species.

Marjoram and clary sage EOs, tested in vapour phase, especially at high concentration $\left(0.42 \mathrm{mg} / \mathrm{cm}^{3}\right)$ resulted in significant inhibition of fungal growth.

\section{2.) The EOs induced changes in the mould morphologys cultivated in liquid} and solid media.

SEM imaging of F. culmorum showed that EO treated hyphae were thinner. Rupture of the cell wall and leakage of the cytoplasm were also observed. All investigated EOs, applied in vapour phase, resulted altered spore colour.

By increasing EO concentration in vapour phase applied to $A$. nomius and $A$. parasiticus, spore production decreased in most cases. Cinnamon EO caused the elongation of hyphae in case of $A$. nomius and $A$. parasiticus cultivated in liquid phase.

\section{3.) EOs had different effect on aflatoxin production of $\boldsymbol{A}$. parasiticus and $\boldsymbol{A}$.} nomius under different experimental conditions.

Marjoram EO vapour, used in solid medium, was the most effective inhibitor of both growth and toxin production of $A$. parasiticus, resulting in high antifungal index and low aflatoxin level. Using marjoram EO, growth was almost completely inhibited, aflatoxin production was significantly decreased, and sporulation stopped. In the solid medium experiments, the toxin production of Aspergillus began to reduce when growth-inhibition reached a certain level. 
When Aspergillus, was grown in liquid medium, aflatoxin level and mycelium dry weight increased initially, but after reaching a maximum, began to decline. In the case of $A$. nomius, low vapour concentrations of all EOs stimulated aflatoxin production. Effective inhibition was achieved only with the highest concentration $\left(0.42 \mathrm{mg} / \mathrm{cm}^{3}\right)$. Cultivated in liquid medium, A. parasitisus produced higher level of aflatoxins than A. nomius.

Though lemon and juniper EOs were less effective in the growth experiments, they were able to reduce aflatoxin production in vapour phase using liquid medium. Cinnamon, marjoram and clary sage EOs, especially at low concentrations, stimulated (and not reduced) aflatoxin production of $A$. parasiticus. The AFG1 was detected in the samples in the largest amounts was AFG1. In most cases, the proportions of aflatoxins were altered at 10 vs. 5 days incubation. This effect was concentration dependent, and was more pronounced with cinnamon, marjoram and clary sage EOs than with lemon und juniper EOs.

\section{4.) Cinnamon essential oil was the only one showing inhibition of} aflatoxin production of $A$. parasiticus on wheat substrate.

Increasing the concentration of cinnamon EO in vapour phase, the aflatoxin production was suppressed effectively. Lemon and clary sage EOs could not significantly decrease the aflatoxin production.

With marjoram EO, stimulation of aflatoxin production by $A$. parasiticus was observed. Despite appropriate incubation conditions, less aflatoxins were measured in all samples at the end, than in the middle of the incubation period, probably due to decomposition of the toxins.

On wheat, the toxins produced in the highest quantities and proportions were AFG1 (63-73\%) and AFB1 (19-38\%). With increasing incubation time, the ratios of aflatoxins changed; and by the end of incubation, the ratio of AFG1 decreased in both control and treated samples while the ratio of AFB1, AFG2, and AFB2 increased. The least change in the proportions of aflatoxins was observed using lemon and clary sage EOs in vapour.

The effect of marjoram EO was opposite on solid medium and on wheat substrate. Using reversed Petri dish method, marjoram EO in vapour phase was the most effective in inhibiting fungal growth and aflatoxin production. On wheat substrate, however, marjoram EO increased the amounts of aflatoxins compared to the control. In this method, cinnamon EO was the most effective, inhibiting toxin production of $A$. parasiticus significantly, while its effect in the reversed Petri dish method was minor. 
Our results showed that the efficiency of EOs were different using different experimental methods. In case of aflatoxin production by $A$. parasiticus, lemon and juniper EOs were the most effective when cultivated in liquid medium, marjoram EO in solid medium, and cinnamon EO using wheat as growth substrate.

In our study, the antifungal effect of EOs was also concentration dependent. Our results showed that EOs might be stress factors that could increase aflatoxin production of the moulds, especially at low concentrations, by inducing oxidative stress. The chemical character of the EOs - determined by their composition - the concentration, and the experimental conditions are important factors in inhibition of aflatoxin synthesis.

Depending on the experimental methods, it proved to be important to choose the proper concentration of EOs to achieve the desired effect.

It has been suggested, that EOs effect the sexual cycle of moulds. In our experiments the conidiogenesis forced back, number of conidia decreased and at the same time hyphae stretched and an increased aflatoxin content was detected.

According to our results, aflatoxin production followed growth and decay of the moulds. Inhibited aflatoxin production could only be achieved at inhibited fungal growth. Contrary to other authors' claim, our results showed that EOs should be applied at sufficiently high concentrations to achieve significant inhibition of both growth and aflatoxin production of Aspergillus moulds. 


\section{IRODALOMJEGYZÉK}

Ácsné Kovacsics, L., Búza, L. (2007) Mikotoxin vizsgálati eredmények a hazai élelmiszerekben. Élelmiszervizsgálati Közlemények. 53:83-86.

Adams, T.H., Wieser, J.K.,Yu, J.H. (1998) Asexual sporulation in Aspergillus nidulans. Microbiol Mol Biol Rev. 62(1):35-54.

Aldred, D., Cairns, V., Magan, N. (2008) Environmental factors affect efficacy of some essential oils and resveratrol to control growth and ochratoxin A production by Penicillium verrucosum and Aspergillus westerdijkiae on wheat grain. J Stored Prod Res. 44(4): 341-346.

Ambrus, Á. (2007) A mintavételezés és a mérés bizonytalansága a mikotoxinok meghatározásánál. Élelmiszervizsgálati Közlemények. 53:5-18.

Asensio, C.M., Grosso, N.R., Rodolfo Juliani, H. (2015) Quality preservation of organic cottage cheese using oregano essential oils. Lwt Food Sci Technol. 60(2):664-671.

Aswani Kumar, Y.V.V., Renuka, R.M., Bodaiah, B., Usha Kiranmayi, M., Vijaya Lakshmi, M., Sudhakar, P. (2016) Mycotoxin Strategies: Impact on Global Health and Wealth. Pharm. Anal. Acta. 7(7):498.

Atanda, O.O., Akpan, I., Oluwafemi, F. (2006) The potential of some spice essential oils in the control of A. parasiticus CFR 223 and aflatoxin production. Food Control. 18(5):601-607.

Ayala-Zavala, J.F., Oms-Oliu, G., Odriozola-Serrano, I., Gonzalez-Aguilar, G.A., AlvarezParrilla, E., Martin-Belloso, O. (2007) Bio-preservation of fresh-cut tomatoes using natural antimicrobials. Eur. Food Res. Technol. 226(5):1047-1055.

Azeez, L.A., Muid, S., Hasnul, B.M. (2016) Identification of volatile secondary metabolites from an endophytic microfungus Aspergillus nomius KUB105. Malays. J. Anal. Sci. 20(4):751-759.

Baiguini, A., Colletta, S., Rebella, V. (2011) Materials and articles intended to come into contact with food: evaluation of the rapid alert system for food and feed (RASFF) 20082010. Ig Sanita Pubbl. 67(3):293-305.

Bakkali, F., Averbeck, S., Averbeck, D., Idaomar, M. (2008) Biological effects of essential oils - a review. Food Chem. Toxicol. 46(2):446--475.

Balouiri, M., Sadiki, M. Ibnsouda, S.K. (2016) Methods for in vVitro eEvaluating aAntimicrobial aActivity: A rReview. J. Pharm. Anal. 6(2):71-79.

Baranyi, N., Despot, D.J., Palágyi, A., Kiss, N., Kocsubé, S., Szekeres, A., Kecskeméti, A., Bencsik, O., Vágvölgyi, Cs., Klarić, M.Š., Varga, J. (2015) Identification of Aspergillus species in Central Europe able to produce G-type aflatoxins. Acta Biol. Hung. 66(3):339-347.

Baranyi, N., Kocsubé, S., Kiss, N., Palágyi, A., Varga, M., Tóth, B., Varga, J. (2014) Identification of potential mycotoxin producing fungi on agricultural products in Hungary and Serbia. Acta Biol. Szeged. 58(2):167-170.

Békési, P. (2010) Ismét a kalászfuzáriózisról. Agrofórum. január: 53-56.

Békési, P. (2014) A kalászfuzáriózis elleni állománykezelés időpontjának megválasztásáról. Agrofórum. május:, 20-21.

Bennett, J. W. (2010) An overview of the genus Aspergillus. 1-17. In: Aspergillus molecular Biology and Genomics. M. Machida and K. Gomi (eds.), Caister Academic Press, Norfolk, UK. 1-17.

Biegelbauer, P. (1995) Gyógyító illatok. Bioenergetic Kiadó. Budapest. 21-28.

Blount, W. P. (1961) Turkey "X" disease. J. Brit. Turkey Fed. 9, 52-54. 
Boonen, J., Malysheva, S.V., Taevernier, L., Diana Di Mavungu,. J., De Saeger, S., De Spiegeleer, B. (2012) Human skin penetration of selected model mycotoxins. Toxicology. 301(1-3):21--32.

Brandl, J., Andersen, M.R. (2017) Aspergilli: Models for systems biology in filamentous fungi. Curr.ent Opin.ion in Syst.ems Biology. 6:67-73.

Brodhagen, M., Keller, N.P. (2006) Signalling pathways connecting mycotoxin production and sporulation. Mol. Plant Pathol. 7(4):285-301.

Buchanan, R.L., Lewis, D.F. (1984) Regulation of aflatoxin biosynthesis: effect of glucose on activities of various glycolytic enzymes. Appl. Environ. Microbiol. 48(2):306--310.

Bueno, J. (2015) Models of evaluation of antimicrobial activity of essential oils in vapour phase: a promising use in healthcare decontamination. Nat. Volatiles \& Essent. Oils. 2(2):16-29.

Bullerman, L.B., Lieu, F.Y., Seier, S.A. (1977) Inhibition of growth and aflatoxin production by cinnamon and clove oils. Cinnamic aldehyde and eugenol. J. Food Sci. 42(4):11071109.

Burgess, L.W., Summerel, B.A., Bullock, S., Gott, K.P., Backhouse, D. (1994) Laboratory manual for Fusarium Research. Fusarium Research Laboratory, Department of Corp Sciences, University of Sidney and Royal Botanical Garden. 3rd edition, 31.

Burt, S.A. (2004) Essential oils: their antibacterial properties and potential applications in foods: a Review. Int. J. Food Microbiol. 94:223-253.

Bayram, O., Braus, G.H. (2012) Coordination of secondary metabolism and development in fungi: the velvet family of regulatory proteins. FEMS Microbiol Rev. 36(1):1-24.

Calvo, A.M., Wilson, R.A., Bok, J.W., Keller, N.P. (2002) Relationship between secondary metabolism and fungal development. Microbiol. Mol. Biol. Rev. 66(3):447--459.

Carson, C.F., Mee, B.J., Riley, T.V. (2002) Mechanism of action of Melaleuca alternifolia (tea tree) oil on Staphylococcus aureus determined by time-kill, lysis, leakage, and salt tolerance assays and electron microscopy. Antimicrob. Agents Ch. 46(6):1914-1920.

Celiktas, O.Y., Kocabas, E.E.H., Bedir, E., Sukan, F.V., Ozek, T., Baser, K.H.C. (2007) Antimicrobial activities of methanol extracts and essential oils of Rosmarinus officinalis, depending on location and seasonal variations. Food Chem. 100(2):553-559.

Chang, P.K. (2003) The Aspergillus parasiticus protein AFLJ interacts with the aflatoxin pathway-specific regulator AFLR. Mol. Genet. Genomics. 268(6):711--719.

Chang, P.K. (2004) Lack of interaction between AFLR and AFLJ contributes to nonaflatoxigenicity of Aspergillus sojae. J. Biotechnol. 107(3):245-253.

Chang, S.T., Chen, P.F., Chang, S.C. (2001) Antibacterial activity of leaf essential oils and their constituents from Cinnamomum osmophloeum. J. Ethnopharmacol. 77(1):123-127.

Cheung, W.Y. (1980) Calmodulin plays a pivotal role in cellular regulation. Science. 207(4426):19-27.

Da Cruz Cabral, L., Fernández Pinto, V., Patriarca, A. (2013) Application of plant derived compounds to control fungal spoilage and mycotoxin production in foods. Int. J. Food Microbiol. 166(1):1-14.

Da Silva Bomfim, N., Nakassugi, L.P., Faggion Pinheiro Oliveira, J., Kohiyama, C.Y., Mossini, S.A., Grespan, R., Nerilo, S.B., Mallmann, C.A., Alves Abreu Filho, B., and Machinski, M. Jr. (2015) Antifungal activity and inhibition of fumonisin production by Rosmarinus officinalis L. essential oil in Fusarium verticillioides (Sacc.) Nirenberg. Food Chem. 166:330-336.

Da Silva, E.O., da,; Bracarense, A.P.F.L., Oswald, I.P. (2018) Mycotoxins and oxidative stress: where are we? World Mycotoxin J. 11 (1):113-133. 
Dalcero, A., Magnoli, C., Hallak, C., Chiacchiera, S.M., Palacio, G., Rosa, C.A. (2002) Detection of ochratoxin A in animal feeds and capacity to produce this mycotoxin by Aspergillus section Nigri in Argentina. Food Addit. Contam. 19(11):1065-1072.

Dambolena, J.S., López, A.G., Cánepa, M.C., Theumer, M.G., Zygadlo, J.A., Rubinstein, H.R (2008) Inhibitory effect of cyclic terpenes (limonene, menthol, menthone and thymol) on Fusarium verticillioides MRC 826 growth and FUMO B1 biosynthesis. Toxicon. 51(1):37-44.

Dambolena, J.S., Lopez, A.G., Rubinstein, H.R., Zygadlo, J.A. (2010) Effects of menthol stereoisomers on the growth, sporulation and FUMO B1 production of Fusarium verticillioides. Food Chem. 123(1): 165-170.

Darvas, B. (2004) Mit őröltek a malmok? Élet és Tudomány 59. 47. 1478-1481.

De Martino, L., De Feo, V., Formisano, C., Mignola, E., Senatore, F. (2009) Chemical composition and antimicrobial activity of the essential oils from three chemotypes of Origanum vulgare L. ssp. hirtum (Link) letswaart growing wild in Campania (Southern Italy). Molecules. 14(8):2735-2746.

Deák, T., Kiskó, G., Maráz, A., Mohácsiné Farkas, Cs. (2006) Élelmiszer-mikrobiológia. Mezögazda kiadó 33-35, 80-87, 103-,104.

Deepa, N., Sreenivasa, M.Y. (2017) Fusarium verticillioides, a globally important pathogen of agriculture and livestock: A review. J. Vet. Med. Res. 4(4):1084.

Delaquis, P.J., Stanich, K., Girard, B., Mazza, G. (2002) Antimicrobial activity of individual and mixed fractions of dill, cilantro, coriander and eucalyptus essential oils. Int. J. Food Microbiol. 74(1-2):101-109.

Demuner, A.J., Barbosa, L.C., Magalhaes, C.G., da Silva, C.J., Maltha, C.R., Pinheiro, A.L. (2011) Seasonal variation in the chemical composition and antimicrobial activity of volatile oils of three species of Leptospermum (Myrtaceae) grown in Brazil. Molecules,. 16(2):1181-1191.

Devkatte, A.N., Zore, G.B., Karuppayil, S.M. (2005) Potential of plant oils as inhibitors of Candida albicans growth. FEMS Yeast Res. 5(9):867-873.

Dexter, J.E., Wood, P.J. (1996) Recent applications of debranning wheat before milling. Trends Food Sci. Tech. 7(2):35-41.

Diekman, M.A., Green, M.L. (1992) Mycotoxins and reproduction in domestic livestock. $J$. Anim. Sci. 70(5):1615-1627.

Dimitrokallis, V., Meimaroglou, D.M., Markaki, P. (2008) Study of the Ochratoxin A effect on Aspergillus parasiticus growth and aflatoxin B1 production. Food Chem. Toxicol. 46(7):2435-2439.

Djenane, D., Yangüela, J., Montañés, L., Djerbal, M., Roncalés, P. (2011) Antimicrobial activity of Pistacialentiscus and Saturejamontana essential oils against Listeria monocytogenes CECT 935 using laboratory media: efficacy and synergistic potential in minced beef. Food Control. 22(7):1046-1053.

Dorman, H.J.D., Deans, S.G. (2000) Antimicrobial agents from plants: antibacterial activity of plant volatile oils. J. Appl. Microbiol. 88(2):308-316.

Draughon, F.A., Ayres, J.C. (1981) Inhibition of aflatoxin production by selected insecticides. Appl. Environ. Microbiol. 41(4):972-976.

Dussault, D., Vu, K.D., Lacroix, M. (2014) In vitro evaluation of antimicrobial activities of various commercial essential oils, oleoresin and pure compounds against food pathogens and application in ham. Meat Sci. 96(1):514-520.

Dutton, M.F. (1988) Enzymes and Aflatoxin Biosynthesis. Microbiol Rev. 52:274-295. 
Ebani, V.V., Nardoni, S., Bertelloni, F., Giovanelli, S., Rocchigiani, G., Pistelli, L., (2016) Antibacterial and antifungal activity of essential oils against some pathogenic bacteria and yeasts shed from poultry. Flavour Fragr. J. 31(4):302-309.

Ehrlich, K.C., Yu, Y. (2009) Aflatoxin-like gene clusters and how they evolved. In: Rai M., Varma A. (eds) Mycotoxins in Food, Feed and Bioweapons. Springer, Berlin, Heidelberg, 65-75.

Emri, T., Molnár, Z., Pusztahelyi, T., Rosén, S., Pócsi, I. (2004) Effect of vitamin E on autolysis and sporulation of Aspergillus nidulans. Appl. Biochem. Biotechnol. 118(13):337-348.

Espina, L., García-Gonzalo, D., Laglaoui, A., Mackey, B.M., Pagán, R. (2013) Synergistic combinations of high hydrostatic pressure and essential oils or their constituents and their use in preservation of fruit juices. Int J Food Microbiol. 161(1):23-30.

Espina, L., Monfort, S., Álvarez, I., García-Gonzalo, D., Pagán, R. (2014) Combination of pulsed electric fields, mild heat and essential oils as an alternative to the ultrapasteurization of liquid whole egg. Int J Food Microbiol. 189:119-125.

Espina, L., Somolinos, M., Lorán, S., Conchello, P., García, D., Pagán, R. (2011) Chemical composition of commercial citrus fruit essential oils and evaluation of their antimicrobial activity acting alone or in combined processes. Food Control. 22(6):896902.

Fakoor M.H., Rasooli, I., Owlia, P., Mazaheri, M., Shokrollahi, F. (2012) Stimulatoinhibitory response to cumin oil in Aflatoxin B1 production of Aspergillus species., Jundishapur J. Microbiol. 6(7):7210.

Fanelli, C., Fabbri, A.A., Finotti, E., Panfili, G., Passi, S. (1983) Cerulenin and tetrahydrocerulenin: Stimulating factors of aflatoxin biosynthesis. T. Brit. Mycol. Soc. 81(2):201-204.

Farkas, J., Szeitzné Szabó, M., Mohácsiné Farkas, Cs. (2014) Mikotoxinok álarcban - új takarmány- és élelmiszerbiztonsági kihívás? Élelmiszervizsgálati közlemények. 2014. LX. (3):52-54.

Ferrigo, D., Raiola, A., Causin, R. (2016) Fusarium toxins in cereals: occurrence, legislation, factors promoting the appearance and their management. Molecules. 21(5):627.

Formisano, C., Delfine, S., Oliviero, F., Tenore, G.C., Rigano, D., Senatore, F. (2015) Correlation among environmental factors, chemical composition and antioxidative properties of essential oil and extracts of chamomile (Matricaria chamomilla L.) collected in Molise (South-central Italy) Ind. Crops Prod. 63:256-263.

García-Díez, J., Alheiro, J., Pinto, A.L., Soares, L., Falco, V., Fraqueza, M.J., (2016) Behaviour of food-borne pathogens on dry cured sausage manufactured with herbs and spices essential oils and their sensorial acceptability. Food Control. 59:262-270.

Gareis, M., Bauer, J., von Montgelas, A., Gedek, B. (1984) Stimulation of aflatoxin B1 and T2 toxin production by sorbic acid. Appl. Environ. Microbiol. 47(2):416-418.

Gautier, M., Michel, J., Normand, A.C., Cassagne, C., Piarroux, R., Ranque, S. (2015) Cochliobolus hawaiiensis sinusitis, a tropical disease? A case report and review of the literature. Mycopathologia. 180(1-2):117-121.

Geiser, D.M. (2009) Sexual structures in Aspergillus: morphology, importance and genomics. Med. Mycol. 47. S21-S26.

Gill, A.O., Delaquis, P., Russo, P., Holley, R.A. (2002) Evaluation of antilisterial action of cilantro oil on vacuum packed ham. Int J Food Microbiol. 73(1):83-92.

Giray, B., Girgin, G., Engin, A.B., Aydin, S., Sahin, G. (2007) Aflatoxin levels in wheat samples consumed in some regions of Turkey. Food Control. 18(1):23-29.

Glits, M., Folk, Gy. (2000) Kertészeti növénykórtan. Mezőgazda Kiadó, Budapest, 132-, 133. 
Goswami, R.S., Kistler, H.C. (2004) Heading for disaster: Fusarium graminearum on cereal crops. Mol. Plant Pathol. 5(6):515-525.

Gourami, H., Bullerman,L.B. (1995) Aspergillus flavus and Aspergillus parasiticus: Aflatoxigenic fungi of concern in foods and feeds: A review. J Food Prot. 58, 13951404.

Gömöri, Cs., Nacsa-Farkas, E., Kerekes, E. B., Vidács, A., Bencsik, O., Kocsubé, S., Khaled, J. M., Alharbi, N. S., Vágvölgyi Cs., Krisch, J. (2018b) Effect of essential oil vapours on Aflatoxin production of Aspergillus parasiticus. World Mycotoxin J. 11(4):579-588.

Gömöri, Cs., Vidács, A., Kerekes, E. B., Nacsa-Farkas, E., Böszörményi, A., Vágvölgyi Cs., Krisch, J. (2018a) Altered antimicrobial and anti-biofilm forming effect of thyme essential oil due to changes in composition. Nat. Prod. Commun., 13(4):483-487.

Guillén, F., Zapata, P.J., Martínez-Romero, D., Castillo, S., Serrano, M., Valero, D. (2007) Improvement of the Overall Quality of Table Grapes Stored under Modified Atmosphere Packaging in Combination with Natural Antimicrobial Compounds. J Food Sci. 72(3):185-190.

Gupta, A., Sharma, S., Naik, S.N. (2011) Biopesticidal value of selected essential oils against pathogenic fungus, termites, and nematodes. Int. Biodeterior. Biodegrad. 65(5):703707.

Gupta, K.A., Ganjewala, D. (2015) A study on developmental changes in essential oil content and composition in Cymbopogon flexuosus cultivar Suvarna. Acta Biol. Szeged. 59(2): 119-125.

Guzman-de-Pena, D., Ruiz-Herrera, J. (1997) Relationship between aflatoxin biosynthesis and sporulation in Aspergillus parasiticus. Fungal Genet. Biol. 21(2):198-205.

Gyimes, E., Véha, A. (2004) Étkezési (őszi) búzák agrofizikai jellemzőinek kapcsolata a szemkeménységgel. Fiatal Müszakiak Tudományos Ülésszaka, Kolozsvár, 77-80.

Haagen-Smit, A.J. (1961) Essential oils. Eng. Sci. 24(8):7-11.

Hamid, A.B., Smith, J.E. (1987) Degradation of aflatoxin by Aspergillus flavus. J. Gen. Microbiol. 133(8):2023-2029.

Han, X., Chakrabortti, A., Zhu, J., Liang, Z.X., Li, J. (2016) Sequencing and functional annotation of the whole genome of the filamentous fungus Aspergillus westerdijkiae. BMC Genomics. 17(1):633.

Hitokoto, H., Morozumi, S., Wauke, T., Sakai, S., Ueno, I. (1978) Inhibitory effects of condiments and herbal drugs on the growth and toxin production of toxigenic fungi. Mycopathologia. 66(3):161-167.

Hope, R., Aldred, D., Magan, N. (2005) Comparison of environmental profiles for growth and deoxynivalenol production by Fusarium culmorum and F. graminearum on wheat grain. Lett App Microbiol. 40(4): 295-300.

Hu, H.L., van den Brink, J., Gruben, B.S., Wösten, H.A.B., Gu, J.D., de Vries, R.P. (2011) Improved enzyme production by co-cultivation of Aspergillus niger and Aspergillus oryzae and with other fungi. Int. Biodeterior. Biodegrad. 65(1):248-252.

Hyldgaard, M., Mygind, T., Meyer, R.L. (2012). Essential oils in food preservation: mode of action, synergies, and interactions with food matrix components. Front. Microbiol. 3(12):1-24.

Inan, F., Pala, M., Doymaz, I. (2007). Use of ozone in detoxification of aflatoxin B1 in red pepper. J. Stored Prod. Res. 43(4):425-429.

Ito, Y., Peterson, S.W., Goto, T. (1998) Isolation and characterization of Aspergillus nomius from Japanese soil and silkworm excrement. Mycotoxins. 46:9-15. 
Jaimez, J., Fente, C.A., Vazquez, B.I., Franco, C.M., Cepeda, A., Mahuzier, G., Prognon, P. (2000) Application of the assay of aflatoxins by liquid chromatography with fluorescence detection in food analysis. J. Chromatogr. A. 882(1-2):1-10.

Jayasena, D.D., Jo, C. (2013) Essential oils as potential antimicrobial agents in meat and meat products: A review. Trends Food Sci. Tech. 34(2):96-108.

Jayashree, T., Subramanyam, C. (2000) Oxidative stress as a prerequisite for aflatoxin production by Aspergillus parasiticus. Free Radic. Biol. Med. 29(10):981-985.

John, L. (2008) Discovery of aflatoxins and significant historical features. Toxin Rev. 27(34):171-201.

Jouany, J.P. (2007) Methods for preventing, decontaminating and minimizing the toxicity of mycotoxins in feeds. Anim. Feed Sci. Technol. 137(3--4):342-362.

Juven, B.J., Kanner, J., Schved, F., Weisslowicz, H. (1994) Factors that interact with the antibacterial action of thyme essential oil and its active constituents. $J$ Appl Bacteriol. 76(6):626-631.

Kakaraparthi, P.S., Srinivas, K.V.N.S., Kumar, J.K., Kumar, A.N., Rajput, D.K., Sarma, V.U.M. (2014) Variation in the essential oil content and composition of Citronella (Cymbopogon winterianus Jowitt.) in relation to time of harvest and weather conditions. Ind. Crops Prod. 61:240-248.

Kamaliroosta, L., Zolfaghari, M., Shafiee, S., Larijani, K., Zojaji, M. (2016) Chemical identifications of citrus peels essential oils., J.ournal of Food Biosci.ences and Technol.ogy, Islamic Azad University, Science and Research Branch. 6(2):69-76.

Kazemi, M., Mokhtariniya, S. (2016) Essential oil composition of bark of Cinnamomum zeylanicum. J.ournal of Eessent.ial Ooil- Bbear.ing Pplants. 19(3):786-789.

Kerekes, E.B., Deák, É., Takó, M., Tserennadmid, R., Petkovits, T., Vágvölgyi, Cs., Krisch, J. (2013) Anti-biofilm forming and anti-quorum sensing activity of selected essential oils and their main components on food-related micro-organisms. J. Appl. Microbiol. 115(4):933-942.

Khlangwiset, P., Shephard, G.S., Wu, F. (2011) Aflatoxins and growth impairment: a review. Crit. Rev. Toxicol. 41(9):740--755.

Kim, J.H., Yu, J., Mahoney, N., Chan, K.L., Molyneux, R.J., Varga, J., Bhatnagar, D., Cleveland, T.E., Nierman, W.C., Campbell, B.C. (2008) Elucidation of the functional genomics of antioxidant-based inhibition of aflatoxin biosynthesis. Int. J. Food Microbiol. 122(1-2):49-60.

Kovács, F., Bíró, G. (2003) Élelmiszer-biztonság, EU szabályozás. Agroinform Kiadó., Budapest, 125.

Krisch, J., Tserennadmid, R., Horváth, G., Vágvölgyi, Cs. (2013) Activity of essential oils in vapor phase against bread spoilage fungi. Acta Biol. Szeged. 57(1):9-12.

Kumar, P., Mahato, D.K., Kamle, M., Mohanta, T.K., Kang, S.G. (2016) Aflatoxins: A global concern for food safety, human health and their management. Front. Microbiol. 7:2170.

Kurtzman, C.P., Horn, B.W., Hesseltine, C.W. (1987) Aspergillus nomius, a new aflatoxinproducing species related to Aspergillus flavus and Aspergillus tamarii. Antonie Van Leeuwenhoek. 53(3):147-158.

Lambert, R.J., Skandamis, P.N., Coote, P.J., Nychas, G.J. (2001) A study of the minimum inhibitory concentration and mode of action of oregano essential oil, thymol and carvacrol. J. Appl. Microbiol. 91(3):453-462.

Laranjo, M., Fernández-Léon, A.M., Potes, M.E., Agulheiro-Santos, A.C., Elias, M. (2017). "Use of essential oils in food preservation", 177-188. In "Antimicrobial Research: Novel bioknowledge and educational programs" (Microbiology Book Series 6). Edited by A. Méndez-Vilas, Formatex Research Center, Badajoz, Spain. 
Leslie, J.F., Summerell, B.A. (2006) The Fusarium Laboratory Manual. Ames, IA, USA:, Blackwell Publishing, 158, 274.

Liu, J., Sun, L., Zhang, N., Zhang, J., Guo, J., Li, C., Rajput, S.A., Qi, D. (2016) Effects of nutrients in substrates of different grains on Aflatoxin B1 production by Aspergillus flavus. Biomed. Res. Int. 2016(1):1-10.:7232858. doi: 10.1155/2016/7232858.

Lu, S., Ji, H., Wang, Q., Li, B., Li, K., Xu, C., (2015) The effects of starter cultures and plant extracts on the biogenic amine accumulation in traditional Chinese smoked horsemeat sausages. Food Control. 50:869-875.

Magan, N., Aldred, D., Hope, R., Mitchell, D. (2010a) Environmental factors and interactions with mycobiota of grain and grapes: Effects on growth, Deoxynivalenol and Ochratoxin production by Fusarium culmorum and Aspergillus carbonarius. Toxins. 2(3): 353-366.

Magan. N., Aldred, D., Mylona, K., Lambert, R.J. (2010b) Limiting mycotoxins in stored wheat - a review. Food Addit Contam Part A Chem Anal Control Expo Risk Assess. 27(5): 644-650.

Manamgoda, D.S., Cai, L., Bahkali, A.H. Chukeatirote, E., Hyde, D. K. (2011) Cochliobolus: An overview and current status of species. Fungal Divers. 51(1):3-42.

Máté, G., Kovács, D., Gazdag, Z., Pesti, M., Szántó, Á. (2017) Linalool-induced oxidative stress processes in the human pathogen Candida albicans. Acta Biol. Hung. 68(2):220231.

Matumba, L., Sulyok, M., Njoroge, S.M., Njumbe Ediage, E., Van Poucke, C., De Saeger, S., Krska, R. (2015) Uncommon occurrence ratios of aflatoxin B1, B2, G1, and G2 in maize and groundnuts from Malawi. Mycotoxin Res. 31(1):57-62.

Max, B., Salgado, J.M., Rodríguez, N., Cortés, S., Converti, A., Domínguez, J.M. (2010) Biotechnological production of citric acid. Braz. J. Microbiol. 41(4):862-875.

Mazidah, A.R.; Bronlund, J.E., Robertson, T.R. (2012) The dynamics of volatile release in Petri Dish based minimum inhibitory concentration measurements. Chemeca 2012: Quality of life through chemical engineering: 23-26 September 2012, Wellington, New Zealand. Barton, A.C.T.: Engineers Australia, 104-113. Conference Paper

McIntyre, M., Berry, D.R, McNeil, B. (2000) Role of proteases in autolysis of Penicillium chrysogenum chemostat cultures in response to nutrient depletion., Appl. Microbiol. Biotechnol. 53(2):235-242.

Mesterházy, Á. (2007) Mikotoxinok a gabonatermesztésben: az élelmiszerbiztonsági kihívás. Élelmiszervizsgálati Közlemények., 53:38-48.

Mézes, M. (2006) Penészgombák és mikotoxinok a takarmányokban és az ellenük való védekezés lehetőségei. Agrárágazat Mezőgazdasági Havilap. 2006. szeptember.

Mihai, A.L., Popa, M.E. (2013) Essential oils utilization in food industry - A literature review, Scientific Bulletin. Series F. Biotechnologies, 17:187-192.

Moore, G.G., Mack, M.B., Beltz B.S. (2015) Genomic sequence of the aflatoxigenic filamentous fungus Aspergillus nomius. BMC Genomics. 16:551.

Munhuweyi, K., Caleb, O.J., Lennox, C.L., van Reenen, A.J., Opara, U.L. (2017) In vitro and in vivo antifungal activity of chitosan-essential oils against pomegranate fruit pathogens. Postharvest Biol Tec. 129:9-22.

Naeini, A., Ziglari, T., Shokri, H., Khosravi, A.R. (2010) Assessment of growth-inhibiting effect of some plant essential oils on different Fusarium isolates. J. Mycol. Med. 20(3):174--178.

Nagy, Z., Köbler, M., Mézes, M., (2009) Adszorbensek a mikotoxin-szennyezett takarmányok kedvezötlen hatásainak a csökkentésére. Állattenyésztés és takarmányozás. 58(5):477488 . 
Nannapaneni, R., Chalova, V.I., Crandall, P.G., Ricke, S.C., Johnson, M.G., and O'Bryan, C.A. (2009) Campylobacter and Arcobacter species sensitivity to commercial orange oil fractions. Int. J. Food Microbiol. 129(1):43-49.

Nguefack, J., Leth, V., Amvam Zollo, P.H., Mathur, S.B. (2004) Evaluation of five essential oils from aromatic plants of Cameroon for controlling food spoilage and mycotoxin producing fungi. Int. J. Food Microbiol., 94(3):329-334.

O'Gorman, C.M., Fuller, H., Dyer, P.S. (2009) Discovery of a sexual cycle in the opportunistic fungal pathogen Aspergillus fumigatus. Nature. 457(7228):471-474.

Oliveira, M.M.M. de,; Brugnera, D.F., Cardoso, M. das G., Alves, E., Piccoli, R.H. (2010) Disinfectant action of Cymbopogon sp. essential oils in different phases of biofilm formation by Listeria monocytogenes on stainless steel surface. Food Control. 21(4):549--553.

Olmedo, R.H., Nepote, V., Grosso, N.R. (2013) Preservation of sensory and chemical properties in flavoured cheese prepared with cream cheese base using oregano and rosemary essential oils. Lwt Food Sci Technol. 53(2):409-417.

Olsen, M., Johnsson, P., Möller, T., Paladino, R., Lindblad, M. (2008) Aspergillus nomius, an important aflatoxin producer in Brazil nuts? World Mycotoxin J. 1(2):123-126.

Omar, H.E.D.M. (2013) Mycotoxins-induced oxidative stress and disase In: (ed.) Makun, H. A., Mycotoxin and food safety in developing countries. InTech, Rijeka.

Oral, N., Vatansever, L., Sezer, C., Aydin, B., Güven, A., Gülmez, M., Başer, K.H., Kürkçüoğlu, M. (2009) Effect of absorbent pads containing oregano essential oil on the shelf life extension of overwrap packed chicken drumsticks stored at four degrees Celsius. Poult Sci. 88(7):1459-1465.

Oren, L., Ezrati, S., Cohen, D., Sharon, A. (2003) Early events in the Fusarium verticillioidesmaize interaction characterized by using a green fluorescent protein-expressing transgenic isolate. Appl. Environ. Microbiol. 69(3):1695-1701.

Passi, S., De Luca, C., Fabbri, A.A., Brasini, S., Fanelli, C. (1994) Possible role of ergosterol oxidation in aflatoxin production by Aspergillus parasiticus. Mycol. Res. 98(3):363-368.

Passone, A.M., Girardi, S.N., Ferrand, A.C., Etcheverry, M. (2012) In vitro evaluation of five essential oils as botanical fungitoxicants for the protection of stored peanuts from Aspergillus flavus and A. parasiticus contamination. Int. Biodeter. Biodegr. 70:82-88.

Payne, G.A., Brown, M.P. (1998) Genetics and physiology of aflatoxin biosynthesis. Annu. Rev. Phytopathol. 36:329-362.

Payne, G.A., Hagler, W.M. Jr. (1983) Effect of specific amino acids on growth and aflatoxin production by Aspergillus parasiticus and Aspergillus flavus in defined media. Appl. Environ. Microbiol. 46(4):805-812.

Pepeljnjak, S., Kosalec, I., Kalodera, Z., Blazević, N. (2005) Antimicrobial activity of juniper berry essential oil (Juniperus communis L., Cupressaceae). Acta Pharm. 55(4):417-422.

Pirbalouti, A.G., Hashemi, M., Ghahfarokhi, F.T. (2013) Essential oil and chemical compositions of wild and cultivated Thymus daenensis Celak and Thymus vulgaris L. Ind. Crops Prod. 48:43-48.

Politeo, O., Jukic, M., Milos, M. (2007) Chemical composition and antioxidant capacity of free volatile aglycones from basil (Ocimum basilicum L.) compared with its essential oil. Food Chem. 101(1):379-385.

Prakash, B., Shukla, R., Singh, P., Kumar, A., Mishra, P.K., Dubey, N.K. (2010) Efficacy of chemically characterized Piper betle L. essential oil against fungal and aflatoxin contamination of some edible commodities and its antioxidant activity. Int. J. Food Microbiol. 142(1-2):114-119. 
Prakash, B., Veeregowda, B.M., Krishnappa, G. (2003) Biofilms: a survival strategy of bacteria. Curr. Sci. India. 85(9):1299-1307.

Puel, O., Galtier, P., Oswald, P.I. (2010) Biosynthesis and toxicological effects of patulin. Toxins. 2(4):613-631.

Quesada, J., Sendra, E., Navarro, C., Sayas-Barberá, E. (2016) Antimicrobial active packaging including chitosan films with Thymus vulgaris L. essential oil for ready-toeat meat. Foods. 5(3):57.

Ranasinghe, L., Jayawardena, B., Abeywickrama, K.P (2002) Fungicidal activity of the essential oils of Cinnamomum zeylanicum L. and Syzygium aromaticum L. Merr et L.M. Perry against crown rot and anthracnose pathogens isolated from banana. Lett App Microbiol. 35 (3) 208-211.

Rao, J.P., Sashidhar, R.B., Subramanyam, C. (19987) Inhibition of aflatoxin productionby trifluoperazine in Aspergillus parasiticus NRRL 2999. World J. Microb. Biot. 14(1): 7175.

Rasooli, I., Fakoor, M.H., Yadegarinia, D., Gachkar, L., Allameh, A., Rezaei, M.B., (2008) Antimycotoxigenic characteristics of Rosmarinus officinalis and Trachyspermum copticum L. essential oils. Int. J. Food Microbiol. 122(1-2):135-139.

Rasooli, I., Owlia, P. (2005) Chemoprevention by thyme oils of Aspergillus parasiticus growth and aflatoxin production. Phytochemistry. 66(24):2851--2856.

Razzaghi-Abyaneh, M., Shams-Ghahfarokhi, M., Yoshinari, T., Rezaee, M.B., Jaimand, K., Nagasawa, H., Sakuda, S. (2008) Inhibitory effects of Satureja hortensis L. essential oil on growth and aflatoxin production by Aspergillus parasiticus. Int. J. Food Microbiol. 123(83):228--233.

Reddy, C.S., Reddy, K.R.N., Prameela, M., Mangala, U.N., Muralidharan, K. (2007) Identification of antifungal component in clove that inhibits Aspergillus spp. colonizing rice grains. J. Mycol. Plant Pathol. 37: 87-94.

Reyes-Jurado, F., Franco-Vega, A., Ramírez-Corona, N., Palou, E., López-Malo, A. (2014) Essential Oils: Antimicrobial Activities, Extraction Methods, and Their Modeling. Food Eng Rev. 7(3):275-297.

Rodrigues, P., Soares, C., Kozakiewicz, Z., Paterson, R.R.M., Lima, N., Venâncio, A. (2007) Identification and characterization of Aspergillus flavus and aflatoxins. Contemp Curr Res Educ Top Tr in Appl Microbio. 527-534.

Samuel, M.S., Aiko, V., Panda, P., Mehta, A. (2013) Aflatoxin B1 occurance, biosynthesis and its degradation. J. Pure Appl. Microbio. 7(2):965-971.

Saulnier, L., Guillon, F., Chateigner-Boutin, A.L. (2012) Cell wall deposition and metabolism in wheat grain. J. Cereal Sci. 56(1):91-108.

Scherm, B., Balmas, V., Spanu, F., Pani, G., Delogu, G., Pasquali, M., Migheli, Q. (2013) Fusarium culmorum: causal agent of foot and root rot and head blight on wheat. Mol. Plant Pathol. 14(4):323-341.

Schmidt-Heydt, M., Magan, N., Geisen, R. (2008) Stress induction of mycotoxin biosynthesis genes by abiotic factors. FEMS Microbiol. Lett. 284(2):142--149.

Schmidt-Heydt, M., Rüfer, C.E., Abdel-Hadi, A., Magan, N., Geisen, R. (2010) The production of aflatoxin B1 or G1 by Aspergillus parasiticus at various combinations of temperature and water activity is related to the ratio of aflS to aflR expression. Mycotoxin Res. 26(4):241-246.

Sebők, F., Dobolyi, C., Zágoni, D., Risa, A., Krifaton, C., Hartman, M., Cserháti, M., Szoboszlay, S., Kriszt, B. (2016) Aflatoxigenic Aspergillus flavus and Aspergillus parasiticus strains in Hungarian maize fields. Acta Microbiol. Immunol. Hung. 63(4):491-502. 
Seenivasan, A., Subhagar, S., Aravindan, R., Viruthagiri, T. (2008) Microbial production and biomedical applications of lovastatin. Indian J. Pharm. Sci. 70(6):701--709.

Shantha, T., Murthy, V.S. (1981) Influence of tricarboxylic acid cycle intermediates and related metabolites on the biosynthesis of aflatoxin by resting cells of Aspergillus flavus. Appl. Environ. Microbiol. 42(5):758-761.

Shewry, P. (2009) The Healthgrain programme opens new opportunities for improving wheat for nutrition and health. Nutr. Bull. 34(2):225--231.

Shi, Z., Shen, S., Zhou, W., Wang, F., Fan, Y. (2008) Fusarium graminearum growth inhibition due to glucose starvation caused by osthol. Int. J. Mol. Sci. 9(3):371-382.

Shukla, R., Singh, P., Prakash, B., Dubey, N.K. (2012) Efficacy of Acorus calamus L. essential oil as a safe plant-based antioxidant, Aflatoxin $\mathrm{B}_{1}$ suppressor and broad spectrum antimicrobial against food-infesting fungi. Int. J. Food Sci. Technol. 48(1):128-135.

Sikkema, J., de Bont, J.A.M., Poolman, B. (1995) Mechanisms of membrane toxicity of hydrocarbons. Microbiol. Rev. 59(2):201--222.

Sindhu, S., Chempakam, B., Leela, N.K., Suseela, Bhai, R. (2011) Chemoprevention by essential oil of turmeric leaves (Curcuma longa L.) on the growth of Aspergillus flavus and aflatoxin production. Food Chem. Toxicol. 49(5):1188-1192.

Sohár, P. (2007) Mikotoxinok az élelmiszerláncban. Élelmiszervizsgálati Közlemények., 53:60-67.

Sokovic, M., Van Griensven, L.J.L.D. (2006) Antimicrobial activity of essential oils and their components against the three major pathogens of the cultivated button mushroom, Agaricus bisporus. Eur. J. Plant Pathol. 116(3):211-224.

Soliman, K.M., Badeaa, R.I. (2002) Effect of oil extracts from some medicinal plants on different mycotoxigenic fungi. Food Chem. Toxicol. 40(11):1669-1675.

Souleles, C., Argyriadou, N. (2008) Constituents of the essential oil of Salvia sclarea growing wild in Greece. Pharm. Biol. 35(3):218-220.

Šramková, Z., Gregová, E., Šturdík, E. (2009) Chemical composition and nutritional quality of wheat grain. Acta Chimica Slovaca. 2(1):115- - 138.

Stevenson, L., Phillips, F., O'sullivan, K., Walton, J. (2012) Wheat bran: its composition and benefits to health, a European perspective. Int. J. Food Sci. Nutr. 63(8):1001-1013.

Suhr, K.I., Nielsen, P.V. (2003) Antifungal activity of essential oils evaluated by two different application techniques against rye bread spoilage fungi. J.ournal of Applied Microbiology., 94(4):665--674.

Sumalan, R-M. Alexa, E., Poiana, M-A. (2013) Assessment of inhibitory potential of essential oils on natural mycoflora and Fusarium mycotoxins production in wheat. Chem Cent J. 7: 32 .

Szabó, E., Szeitzné Szabó, M. (2007) Mikotoxinok az Európai Unió Gyors Veszélyjelző Rendszerében., Élelmiszervizsgálati Közlemények. 53:68-82.

Szeitzné Szabó, M., Frecskáné Csáki, K. (2013) Az aflatoxin szennyezettség csökkentésének lehetőségei az élelmiszerláncban. Nemzeti Élelmiszerlánc-biztonsági Hivatal kiadványa. 7-14.

Szigeti, Gy., Baranyi, N., Kocsubé, S., Győri, T., Szekeres, A., Tóth, B., Török, O., Háfra, E., Pálfi, X., Varga, J. (2012) Role of Aspergillus species in mycotoxin contamination of agricultural products in Central Europe. In: International Symposium: Current Trends in Plant Protection, 25-28 Sept 2012, Belgrad, Szerbia.

Tahmasebi, S., Majd, A., Mehrafarin, A., Jonoubi, P. (2016) Comparative ontogenetic survey of the essential oil composition in Origanum vulgare L., and Origanum majorana L. Acta Biol. Szeged., 60(2):105-111. 
Tam, E.W., Chen, J.H., Lau, E.C., Ngan, A.H., Fung, K.S., Lee, K.C., Lam, C.W., Yuen, K.Y., Lau, S.K., Woo, P.C. (2014) Misidentification of Aspergillus nomius and Aspergillus tamarii as Aspergillus flavus: characterization by internal transcribed spacer, $\beta$-tubulin, and calmodulin gene sequencing, metabolic fingerprinting, and matrix-assisted laser desorption ionization-time of flight mass spectrometry. J. Clin. Microbiol. 52(4):1153-1160.

Teissedre, P.L., Waterhouse, A.L. (2000) Inhibition of oxidation of human low- density lipoproteins by phenolic substances in different essential oils varieties. J. Agric. Food Chem. 48(9): 3605-3801.

Temesvári, G. (2003) Illóolajokkal az egészségért. Kiadó: Bio Ter Bt., második átdolgozott kiadás, 8-9, 20, 23, 31.

Téren, J., Novák, E.K. (1990) Mikotoxinok, Toxinogén gombák. In: Téren J. et al. (szerk), Mikotoxinok, Toxinogén gombák, Mikotoxikózisok Magyar Élelmezéstudományi Egyesület kiadványa.

Terzić, S., Pleadin, J., Šandor, K., Vulić, A., Perši, N., Žarković, I., Andrišić, M., Jemeršić, L., Sušanj, M.W. (2012) Aflatoxin B1 in wheat bran containing premix. Veterinarski arhiv. 82(2):155-166.

Tóth, B., Kótai, É., Varga, M., Pálfi, X., Baranyi, N., Szigeti, Gy., Kocsubé, S., Varga, J. (2013) Climate change and mycotoxin contamination in central Europe: an overview of recent findings. Rev. Agric. Rural Develop. 2(1):461-466.

Tóth, B., Török, O., Kótai, É., Varga, M., Toldiné Tóth, É., Pálfi, X., Háfra, E., Varga, J., Téren, J., Mesterházy, Á. (2012) Role of Aspergilli and Penicillia in mycotoxin contamination of maize in Hungary. Acta Agron. Hung. 60 (2):143-149.

Tsai, S.C., Ames, B.D., (2009) Structural enzymology of polyketide synthases. Methods Enzymol. 459:17-47.

Uraih, N., Chipley, J.R. (1976) Effects of various acids and salts on growth and aflatoxin production by Aspergillus flavus NRRL 3145. Microbios. 17(67):51-59.

Usano-Alemany, J., Palá-Paúl, J., Herraiz-Peñalver, D. (2016) Essential oil yields and qualities of different clonal lines of Salvia lavandulifolia monitored in Spain over four years of cultivation. Ind. Crops Prod. 80:251-261.

Valero, D., Valverde, J.M., Martínez-Romero, D., Guillén, F., Castillo, S., Serrano, M. (2006) The combination of modified atmosphere packaging with eugenol or thymol to maintain quality, safety and functional properties of table grapes. Postharvest Biol Tec. 41(3):317-327.

Van de Braak, S.A.A.J., Leijten, G.C.J.J. (1999) Essential oils and oleoresins: A survey in the Netherlands and other major markets in the European Union. CBI, centre for the promotion of imports from developing countries, Rotterdam, 116.

Van Egmond, H.P. (1989) Current situation on regulations for mycotoxins. Overview of tolerances and status of standard methods of sampling and analysis. Food Addit. Contam. 6(2):139-188.

Varga, J., Kocsubé, S., Suri, K., Szigeti, Gy., Szekeres, A., Varga, M., Tóth, B., Bartók, T. (2010) Fumonisin contamination and fumonisin producing black Aspergilli in dried vine fruits of different origin. Int. J. Food Microbiol. 143(3):143-149.

Varga, J., Rigó, K., Lamper, C., Téren, J., Szabó, G. (2002) Kinetics of ochratoxin A production in different Aspergillus species. Acta Biol. Hung. 53(3):381-388.

Varga, J., Samson, R.A. (2008) Ribotoxin genes in isolates of Aspergillus section Clavati. Antonie Van Leeuwenhoek. 94(3):481-485.

Velluti, A., Sanchis, V., Ramos, A.J., Egido, J., Marın, S. (2003) Inhibitory effect of cinnamon, clove, lemongrass, oregano and palmarose essential oils on growth and 
FUMO B1 production by Fusarium proliferatum in maize grain. Int J Food Microbiol. 89(2-3): 145-154.

Ventura, M., Gómez, A., Anaya, I., Díaz, J., Broto, F., Agut, M., Comellas, L. (2004) Determination of aflatoxins B1, G1, B2 and G2 in medicinal herbs by liquid chromatography-tandem mass spectrometry. J. Chromatogr. A. 1048(1):25-29.

Vera, R.R., Chane-Ming, J. (1999) Chemical composition of the essential oil of marjoram (Origanum majorana L.) from Reunion Island. Food Chem. 66(2):143-145.

Vipotnik, Z., Rodríguez, A., Rodrigues, P. (2017) Aspergillus westerdijkiae as a major ochratoxin A risk in dry-cured ham based-media. Int. J. Food Microbiol. 16(241):244251.

Viuda-Martos, M., Ruiz-Navajas, Y., Fernández-López, J., Pérez-Álvarez, J.A. (2010a) Effect of added citrus fibre and spice essential oils on quality characteristics and shelf-life of mortadella. Meat Sci. 85(3):568-576.

Viuda-Martos, M., Ruiz-Navajas, Y., Fernández-López, J., Pérez-Álvarez, J,A. (2010b) Effect of orange dietary fibre, oregano essential oil and packaging conditions on shelf-life of bologna sausages. Food Control. 21(4):436-443.

Wee, J., Day, D.M.,, Linz, J.E. (2016) Effects of Zinc Chelators on aflatoxin production in Aspergillus parasiticus. Toxins (Basel). 8(6):171.

White, S., McIntyre, M., Berry, D.R., McNeil, B. (2002) The autolysis of industrial filamentous fungi. Crit. Rev. Biotechnol. 22(1):1-14.

Wilkinson, J.R., Yu, J., Bland, J.M., Nierman, W.C., Bhatnagar, D., Cleveland, T.E. (2007) Amino acid supplementation reveals differential regulation of aflatoxin biosynthesis in Aspergillus flavus NRRL 3357 and Aspergillus parasiticus SRRC 143. Appl. Microbiol. Biotechnol. 74(6):1308-1319.

Williams, J.H., Phillips, T.D., Jolly, P.E., Stiles, J.K., Jolly, C.M., Aggarwal, D. (2004) Human aflatoxicosis in developing countries: a review of toxicology, exposure, potential health consequences, and interventions. American J. Clin. Nutr. 80(5):11061122.

Wilson, D.M. (1989) Analytical methods for aflatoxins in corn and peanuts. Arch. Environ. Contam. Toxicol. 18(3):308-314.

Wolde, M. (2016) Effects of aflatoxin contamination of grains in Ethiopia. Int. J. Agric. Sci. 7(4):1298-1308.

Woloshuk, C.P., Foutz, K.R., Brewer, J.F., Bhatnagar, D., Cleveland, T.E., Payne, G.A. (1994) Molecular characterization of aflR, a regulatory locus for aflatoxin biosynthesis. Appl. Environ. Microbiol. 60(7):2408-2414.

Yamamoto-Ribeiro, M.M., Grespan, R., Kohiyama, C.Y., Ferreira, F.D., Mossini, S.A., Silva, E.L., Filho, B.A., Mikcha, J.M., Machinski, M. Jr. (2013) Effect of Zingiber officinale essential oil on Fusarium verticillioides and fumonisin production. Food Chem. 141(3):3147-3152.

Yang, F., Jacobsen, S., Jørgensen, H.J., Collinge, D.B., Svensson, B., Finnie, C. (2013) Fusarium graminearum and its interactions with cereal heads: studies in the proteomics era. Front. Plant Sci. 4:37.

Yin, Y.N., Yan, L.Y., Jiang, J.H., Ma, Z.H. (2008) Biological control of aflatoxin contamination of crops. J Zhejiang Univ Sci B. 9(10): 787-792.

Yousef, A.E., Marth, E.H. (1981) Growth and synthesis of aflatoxin by Aspergillus parasiticus in the presence of sorbic acid. J. Food Prot. 44(10):736-741.

Yu, J. (2012) Current understanding on aflatoxin biosynthesis and future perspective in reducing aflatoxin contamination. Toxins 4(11):1024-1057. 
Yu, J., Chang, P.K., Ehrlich, K.C., Cary, J.W., Bhatnagar, D., Cleveland, T.E., Payne, G.A., Linz, J.E., Woloshuk, C.P., Bennett, J.W. (2004) Clustered pathway genes in aflatoxin biosynthesis. Appl. Environ. Microbiol. 70(3):1253-1262.

Zheng, W., Zhao, X., Xie, Q., Huang, Q., Zhang, C., Zhai, H., Xu, L., Lu, G., Shim, W.B., Wang, Z. (2012) A conserved homeobox transcription factor Htfl is required for phialide development and conidiogenesis in Fusarium species. PLoS One.7(9). 


\section{KÖSZÖNETNYILVÁNÍTÁS}

Témavezetőimnek, Prof. Dr. Vágvölgyi Csabának és Dr. Krisch Juditnak, akik végig figyelemmel kísérték munkámat és fáradhatatlanul javították, segítették ténykedésemet.

Dr. Szekeres András tudományos főmunkatársnak és Dr. Nyilasi Ildikó tudományos munkatársnak, akik észrevételeikkel, szakmai tanácsaikkal segítettek disszertációm javításában, jobbá tételében.

Köszönöm segítségét Dr. Téren Józsefnek, egykori tanáromnak és szakdolgozati konzulensemnek, akivel a téma feldolgozását elkezdtük, aki biztatott a folytatásra és mindvégig mellettem állt.

Hálával emlékezem Dr. Laskay Gáborra, angol tanáromra, akinek középfokú angol nyelvvizsgámat köszönhetem és aki az egyetem elvégzését követően 2013-ban biztatott a tanulmányaim folytatásra, a Doktori Iskola megkezdésére.

Köszönöm áldozatkész felkészítését angoltanáromnak, Horváth Tündének, aki segítségével tovább tökéletesítettem angol nyelvtudásomat.

Hálával tartozom Nacsa-Farkas Elvirának, az SZTE TTIK Mikrobiológiai Tanszék laboratóriumi munkatársának, aki türelemmel kísérte végig munkámat, és akinek a segítségére mindig számíthattam.

Köszönöm támogatását az SZTE TTIK-n tanuló valamennyi hallgató társamnak és ott dolgozó kollégának, akik segítségére mindig számíthattam. Kiemelt köszönetemet fejezem ki Dr. Bencsik Ottónak, Dr. Bencsik-Kerekes Erika Beátának, Dr. Kocsubé Sándornak, Dr. Vidács Anitának, Endre Gábornak. Kollégámnak, Báló Gábornak, aki mindig segítségemre volt a matematikai és informatikai kérdések megoldásában. Szüleimnek, Veres Mihálynak és Veres Mihálynénak, lányomnak, Gömöri Csengének, páromnak, Major Lászlónak, akik töretlen lendülettel segítettek.

A dolgozattal kapcsolatos kutatásokat az „Új utak a természetes anyag alapú gyógyszerkutatásban: Rendszermetabolomikai megközelítések növényi és mikrobiális eredetű bioaktív terpenoidok felkutatására.” címü, GINOP-2.3.2-15-2016-00012 számú projekt támogatta. Valamint az infrastruktúrális hátteret a GINOP-2.3.3-15-2016-00006 számú, „Mikrobiális génbankoz kapcsolódó integrált élettudományi és hatóanyag kutatás-fejlesztési centrum” címü pályázat biztosította. 